\title{
HE MANA TAONGA, HE MANA TANGATA: MĀORI TAONGA AND THE POLITICS OF MĀORI TRIBAL IDENTITY AND DEVELOPMENT
}

\author{
by \\ Arapata Tamati Hakiwai
}

\begin{abstract}
A thesis
submitted to the Victoria University of Wellington

in fulfilment of the requirements for the degree of

Doctor of Philosophy in

Museum and Heritage Studies
\end{abstract}

Victoria University of Wellington

November 2014 


\section{Tuhinga Whakarāpopoto - Abstract}

In museum studies, museums have been examined in terms of their historical role in collecting and exhibiting the culture of colonized peoples, and their contemporary participation in identity politics, repatriation and relationships with source communities, but their role in indigenous tribal development has never been the focus of a major study. This thesis sets out to examine this phenomenon and thereby address a major gap in the literature. In New Zealand, Māori tribes are actively pursuing social, cultural and economic development initiatives as an expression of their mana motuhake or self-determination. The development ethos that is guiding many of these tribes has at its core the wellbeing of their people and the importance of their culture and tribal identity to social and economic development.

The research into this extraordinary politics of Māori tribal identity and development seeks to understand the role Māori taonga play both historically and within contemporary Māori communities as part of tribal self-determination and the advancement of Māori development and identity. The questions framing the study include the following: What is the nature of Māori taonga and what is their relationship with the politics of Māori tribal identity and development? What value are museums, collections of taonga or other cultural heritage in the process of iwi development which is taking place during the Waitangi claims process and Post Settlement phase?

Using a research methodology that incorporates a Kaupapa Māori paradigm, as well as methodologies used in museum studies and related fields, this research investigates the experiences of a number of Māori tribes with regard to their tribal taonga and cultural heritage projects including tribal exhibitions. Major case studies include Ngāi Tahu, Ngāti Kahungunu and Ngāti Porou along with an examination of secondary sources such, as tribal websites, tribal visions and strategic plans, and other published materials.

The research findings demonstrate that taonga are important and enduring symbols of Māori identity, which are often used in the assertion and promotion of tribal self-determination and development. Māori tribal values such as mana, whakapapa, manaakitanga, tikanga, kōrero, whanaungatanga and kaitiakitanga along with taonga related kupu (words) shape and influence many tribal development strategies. The literature and interviews from tribal 
members confirm the enduring significance of taonga to whānau, hapū and iwi. The research demonstrates the role taonga play in sustaining the inter-generational continuity of tribal culture and the 'connectedness' of taonga to the wider culture, including the pivotal role they play in informing and shaping tribal development futures. 


\section{Whakamihi - Acknowledgements}

\section{Ehara taku toa $i$ te toa takitini engari takimano}

There are many people that I owe a debt of gratitude in my journey to complete my doctorate. It has been a long and fulfilling journey and there have been many people, friends and colleagues who have played an important role in helping to shape my future. My deepest aroha and mihi must go to my whānau who have endured many long hours over the last 4 years. To my loving and supportive wife, thank you for putting up with me and being my most ardent supporter. You kept my focus going and you provided a much needed prod on many occasions. Thanks Gloria. E kore e taea te kōrero ngakau nui mou. To my father-in-law Pita Wilkie, who sadly passed beyond the veil in 2007, thank you for all the support and aroha you gave to me as part of the wider whānau.

To my supervisors Dr David Butts and Dr Conal McCarthy, a special debt of gratitude for your patience, wisdom and deep knowledge in steering the waka when at times it was going wayward from side to side. Your knowledge and experience was invaluable to my research and your feedback was always constructive and timely. Tēnā kōrua mo a kōrua pukenga, a kōrua tautoko mai.

The proverb that I have started this doctoral thesis with is my way of acknowledging the multitudes of people who have influenced me, been with me, helped me or just been there while I have embarked on my journey. At a personal level I acknowledge my ancestors and whānau who I know have guided and looked after me during this time. The journey to undertake research for a doctorate is not an easy one as it requires commitment and drive from start to finish and there were times when I really understood the words of our ancestors recorded in one of my tribal waiata oriori or lullaby, the 'Waiata Oriori mo Tūteremoana', when it described the ascent of Tāne-nui-a-rangi to acquire the ancestral kits of knowledge “Kotahi tonu te hiringa i kake ai Tāne ki Tikitiki-o-rangi, Ko te hiringa i te mahara". Translated, this means that there was only one reason why Tāne acquired the three kits of knowledge: it was through the primal desire of the mind.

Although this may be presumptuous, I do want to acknowledge the many Māori tribal leaders who have advanced development initiatives for both Māoridom and their tribes. A special 
mihi and gratitude to Sir Hirini Moko Mead who has unselfishly made a huge contribution to Māori society and culture and to our nation. I was privileged to be in his classes at Victoria University in the 1980s and it was because of this that my career changed direction. The fascinating dialogue and tensions between the museum fraternity and Māori during the Te Māori exhibition inspired me to work in museums and work towards making a difference. Hirini, you have achieved and contributed so much for us all and I just hope that in some humble way this may be a way of contributing back and saying thank you. To you, Mina McKenzie, thanks for the inspiration and belief in making dreams possible. To my aunties, Ruruhira Robin and Ngāikiha Tawhai, I miss you two so much. You were my sheltering tree and always found time for me in your busy lives. Moe marire mai kōrua i te wāhi ngaro. Ko tēnei tuhituhinga he takoha aroha ki a kōrua.

To my dear friend and elder, Te Ikanui Kapa of Te Aupouri, who sadly passed away in 2007, your words, wisdom and daily kōrero continue to be my inspiration. A big thanks to David Jones for kindly agreeing for me to reprint the words of the haka 'Te Hau ki Türanga' performed at the Te Matatini Performing Arts in 2011. Undertaking a PhD can be a lonely exercise as often you are on your own reading books, researching archives and writing draft after draft. To my many friends and colleagues who I have pestered over the last four years, thank you for putting up with me.

Finally thanks also to Te Papa for providing me time and space to undertake this research when there were so many projects on the go. Without your agreement and support I could not have completed the journey. To you, Michelle, tēnā koe and to the late Dr Seddon Bennington, a big mihi for your tautoko and encouragement. E moe marire mai koe. 


\section{Rārangi Upoko - Table of Contents}

Tuhinga Whakarāpopoto - Abstract ..........................................................................ii

Whakamihi - Acknowledgements ...............................................................................

Rārangi Upoko - Table of Contents ................................................................................. vi

Whakaahua - Illustrations..................................................................................ii

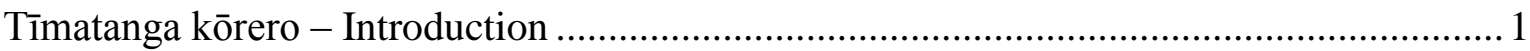

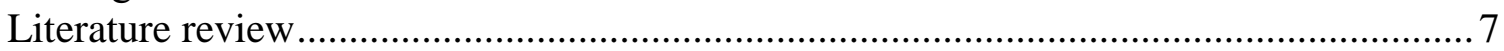

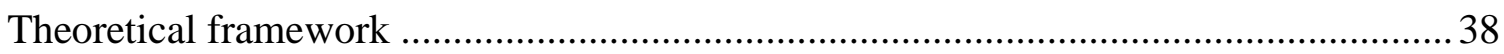

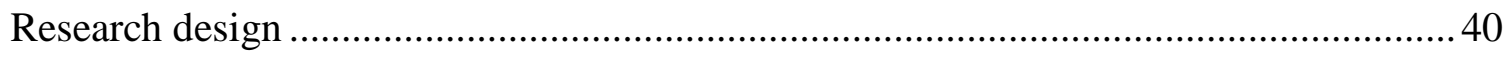

Chapter One: He Whare Taonga, He Mana Tangata - Māori Tribal Taonga.....................51

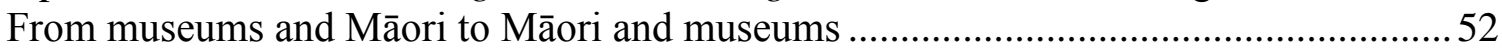

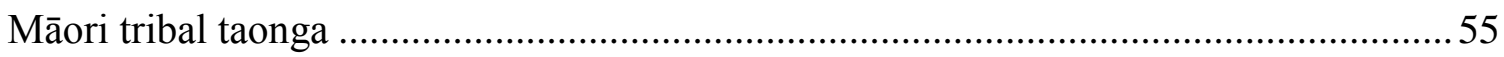

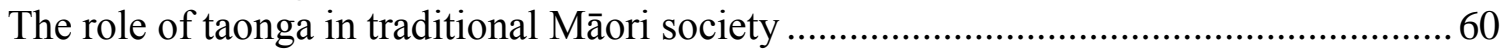

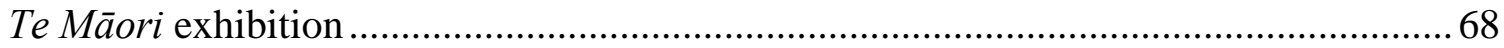

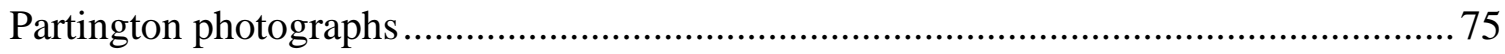

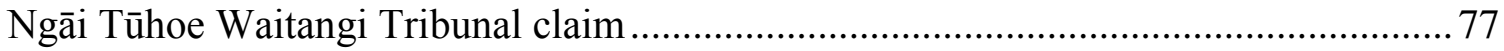

Chapter Two: He Tino Rangatiratanga, He Mana Motuhake - Assertions of Sovereignty 80

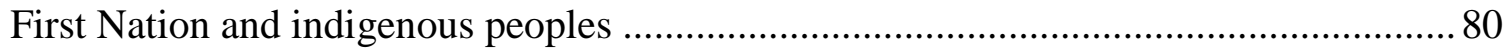

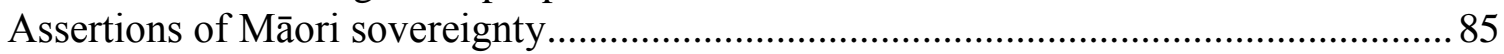

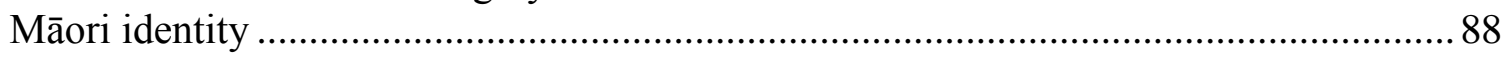

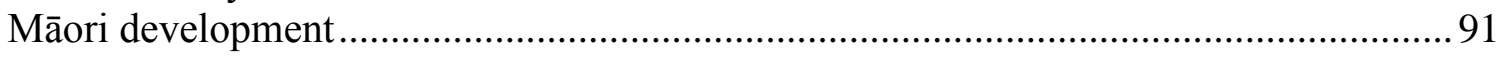

Chapter Three: Mō Tātou, à, Mō Kā uri à muri ake nei - The Politics of Ngāi Tahu Tribal

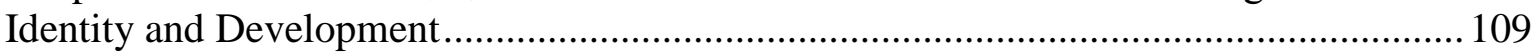

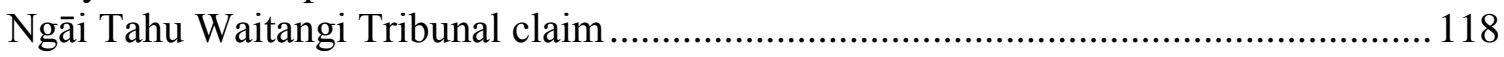

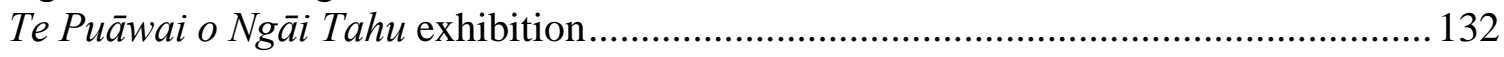

Ngāi Tahu Pouwhenua - Project Hikina taku mana..................................................... 133

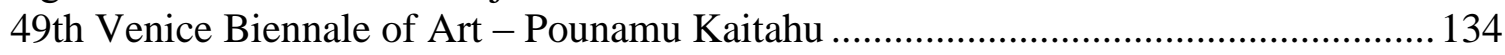

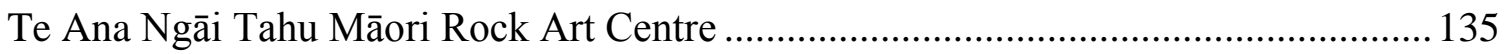

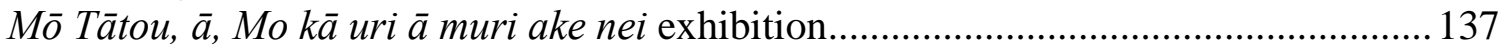

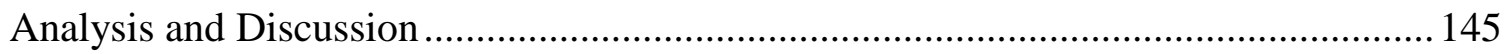

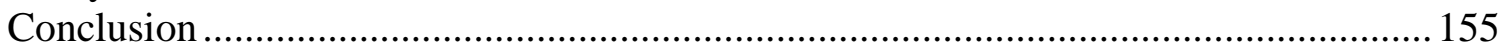

Chapter Four: Kahungunu Ka Moe Ka Puta - The Politics of Ngāti Kahungunu Tribal

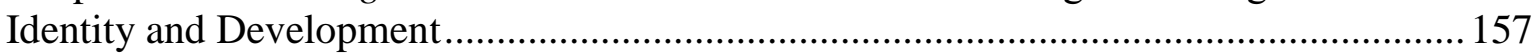

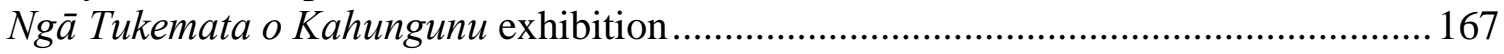

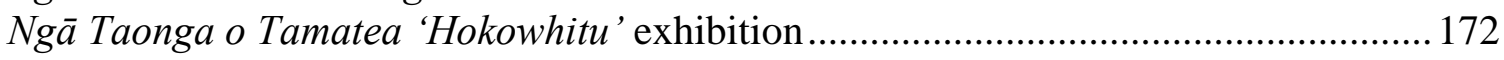

National Library Cultural Property Pilot Project........................................................ 174

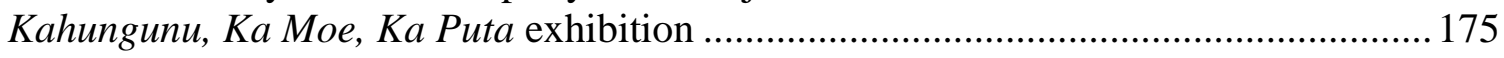

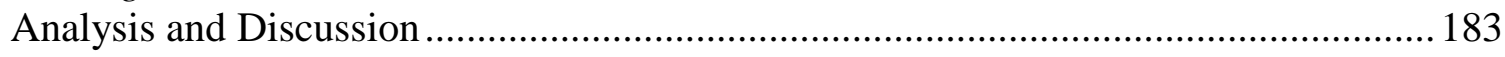

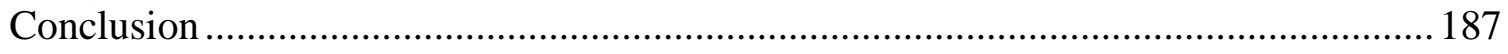


Chapter Five: Toitū te Mana: Taonga Tuku Iho, Taonga Tūturu - An Enduring Tribal Legacy 189

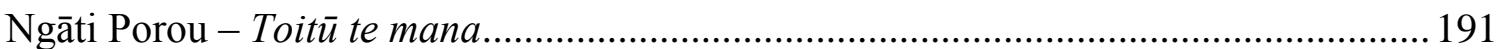

Te Aitanga-a-Hauiti - Ka tipu te whaihanga, e hika, ki Ūawa .....................................199

Rongowhakaata - Te Hau ki Türanga wharenui......................................................21

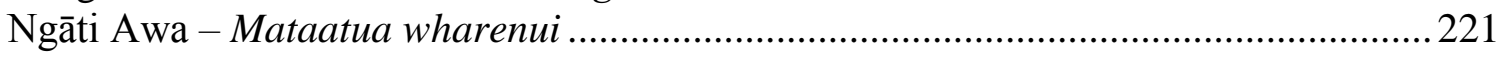

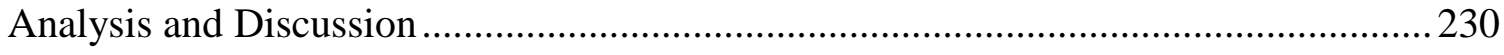

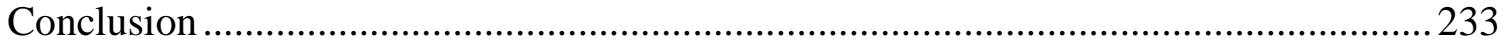

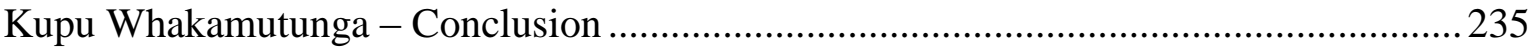

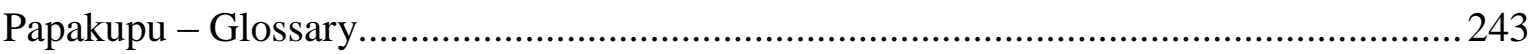

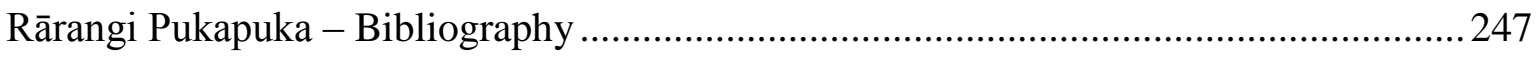




\section{Whakaahua - Illustrations}

\begin{tabular}{|l|l|l|}
\hline Fig 1. & Mason Durie's 'Whare Tapa Wha' model. & \\
\hline Fig 2. & $\begin{array}{l}\text { The Mō Tãtou Ngāi Tahu Iwi exhibition poster at Te } \\
\text { Papa. }\end{array}$ & \\
\hline Fig 3. & $\begin{array}{l}\text { The Mō Tãtou Ngāi Tahu Iwi exhibition poster at the } \\
\text { Canterbury Museum, Christchurch. }\end{array}$ & \\
\hline Fig 4. & $\begin{array}{l}\text { Posters of the four locations of the Kahungunu Ka } \\
\text { Moe Ka Puta Exhibition. Copied from Huria Robens. } \\
\text { Fig 5. }\end{array}$ & $\begin{array}{l}\text { Carnell photograph of ancestor montage, Alexander } \\
\text { Turnbull Library, Wellington. }\end{array}$ \\
\hline Fig 6. & Mataatua at the Sydney International Exhibition 1879. & \\
\hline Fig 7. & Mataatua back in Whakatāne 2011. & \\
\hline Fig 8. & Te Hau ki Tūranga in Te Papa. & \\
\hline
\end{tabular}




\section{Tīmatanga kōrero - Introduction}

In the early 1990s, I helped lead the restoration of the Ruatepupuke carved wharenui or meeting house in the Field Museum, Chicago. The wharenui belonged to the Te Whānau-aRuataupare tribe of Ngāti Porou of Tokomaru Bay on the East Coast of the North Island. Originally opened in September 1881, Ruatepupuke was sold not long after and departed the shores of New Zealand in the early 1890s. After being purchased by the well-known dealer of Pacific and Māori artefacts J.F.G. Umlauff sometime in the 1890s, it was then shipped off to Frankfurt where it was later purchased by the Field Museum in 1919. ${ }^{1}$ The restoration of Ruatepupuke was a major project for the Field Museum and was initiated largely because of the highly successful Te Māori exhibition that was held at the Field Museum in 1985. Tribal descendants wept at seeing their ancestral meeting house for the first time and there was large support to restore Ruatepupuke to its former state. Seeing the pāua shell eyes of this large meeting house penetrate through me when I first stood before it made me think about the value of tribal taonga to their descendant source communities.

While working on Ruatepupuke I was invited to the inaugural meeting of the Centre for Cross Cultural Understanding (now called the Diversity Alliance) at the Field Museum. The senior management team was very interested in knowing more about the mutual partnership established between their museum and the 'native' community from New Zealand (i.e. Te Whānau-a-Ruataupare) regarding Ruatepupuke. They seemed intrigued and perplexed because what was unravelling before their eyes was a process of dynamic engagement that centered on a significant Māori taonga that had been in their care since 1919. Reconnecting with the descendant source community of Tokomaru Bay from whence the meeting house originated was critically important for the project. The mutually beneficial relationship that was being established between the tribe and the museum was noted at the highest level at the Field Museum and they were very interested in knowing what made this project successful. The Field Museum anthropologist John Terrell recognized that their museum was in a dilemma when he said that they were "rich in collections and poor in relations." It was these

1 Umlauff was the well-known collector/dealer of Pacific artefacts and owned an 'emporium' of taonga where he sold large collections to museums in Europe. Umlauff published a catalogue in 1902 where he offered the house for sale. In 1905 the Field Columbian Museum (now the Field Museum) through its curator George Dorsey purchased Ruatepupuke for 20,000 German marks. See Hakiwai, Arapata, and John Terrell. 1994. Ruatepupuke: A Māori Meeting House in the Field Museum of Natural History: Chicago, Illinois. Chicago, Illinois: Field Museum.

2 John Terrell, 1991. 
words that made me think critically about museum theory and practice and the place of taonga within their source communities, given their values, principles and knowledge systems.

Dame Anne Salmond wrote in 1983 that it was almost impossible to put the carvings, photographs, chants, manuscripts, maps and genealogies that were scattered in institutions back together again. ${ }^{3}$ This research is a contemporary response to this challenge: how to reassemble the fragmented cultural heritage as a resource for development and growth. Thirty years later in April 2010, at a joint meeting between the Museum of New Zealand Te Papa Tongarewa (Te Papa), Archives New Zealand and the National Library of New Zealand, Dr Linda Smith, a member of the Ngāti Porou Waitangi Claimant Group Te Haeata, made the following comment with regard to Ngāti Porou taonga that are now in collections throughout the world: "Bits and pieces all over the place" and that it's important to bring them home again - "making us whole again." The purpose of the meeting was to discuss the Ngāti Porou Waitangi Tribunal Deed of Settlement Letter of Commitment relating to the care, management, access and use of Ngāti Porou taonga through national collecting institutions. Smith's impassioned plea for all Ngāti Porou taonga to be returned to Ngāti Porou so that they, the people, could be made 'whole' again spoke to the legacy of colonization and the enduring power of taonga tuku iho. Her words affirmed the link between Ngāti Porou tribal taonga and Ngāti Porou tribal identity and said to those present that these tribal treasures have a role in helping to shape the future development of Ngâti Porou people. This thesis examines the role that taonga play in Māori tribes with respect to the construction of tribal identity and their role sustaining tribal development.

There is a major gap in the literature of museum studies and related fields with respect to the agency of Māori tribal taonga and their relationships to Māori tribal identity and development. In this thesis, Māori tribal exhibitions, cultural projects and Māori tribal development policies and initiatives provide a good foundation on which to assess the relationship between Māori tribal identity and development through the agency of taonga. My contribution will be to examine the topic from an indigenous tribal perspective.

Salmond, Anne. 1983. "The Study of Traditional Māori Society: the State of the art”. The Journal of the Polynesian Society no. 92 (3):309-332. 
The comments made by the museum academic Barbara Kirshenblatt-Gimblett with regard to the Māori worldview of taonga take on a renewed focus for this research when she says: "For taonga the issue is not a second life as an exhibit. What is at stake is the restoration of living links to taonga that never died."

In this thesis, the main research question is: What is the role Māori taonga play within contemporary Māori communities as part of tribal self-determination and the advancement of Māori development and identity? In the context of contemporary social and economic development, it seems that taonga and elements of cultural heritage are being used in a range of ways, including identity-making, artistic reclamation, cultural tourism, relationshipbuilding, health, and economic tribal development. The nature and role of tribal taonga within the Māori world is at the heart of this research along with the complexities of the politics of Māori tribal identity and development.

Taonga are cultural markers and symbols linked to place, space and time, connecting past generations to contemporary descendants, marking an array of relationships to overcome conflict, create knowledge relationships and act as catalysts for sustainability and tribal social and economic development. The question of what role taonga play in the Māori world is a critical aspect of this research and helps to address a major gap in the literature. As Tapsell notes: "Not yet fully explored in museological discourse is the equally important ancestral relationship by which museum-held objects are "valued" within their respective source communities". 5

Tapsell believes that if we become more aware of the significance of these taonga to their source communities, this can lead to more 'purposeful source community engagement'. Writing from a Te Arawa tribal perspective, Tapsell adopts the tui bird and comet as metaphors to express the nature of Te Arawa taonga linking up the myriad interconnected relationships within the genealogical patterned universe of Māori society. Just as the tui bird stitches back and forward, appearing and disappearing, Tapsell adopts the flight of the tui

4 Kirshenblatt-Gimblett, Barbara. 1998. Destination Culture: Tourism, Museums and Heritage. Berkeley University of California Press. 165.

5 Tapsell, Paul. 2011. “'Aroha mai: Whose museum?': The rise of indigenous ethics within museum contexts: A Māori-tribal perspective.” In The Routledge Companion to Museum Ethics: Redefining Ethics for the Twenty-First-Century Museum, edited by Janet Marstine, 85-111. London \& New York: Routledge. 86. 
bird and orbital pathway of the comet to show the deeper understanding of taonga where treasures are sometimes hidden away, gifted and reappearing sometimes generations later. ${ }^{6}$

Durie has stated that: "Cultures change and develop but in shaping a vision for the future the configuration of the past often provides a framework for reconfiguring that future.", Māori tribes have been in a constant state of response and change since European Settlement and this also continues in the current time of Treaty Settlements. Tribes are becoming more corporate, more financially independent and more diverse and variable in their development. The second part of Durie's statement provides an important proposition for this research to investigate. He argues that the 'configuration of the past' often provides the framework for reconfiguring the future. The examination of tribal development visions and strategies through the case studies will show how tribal aspirations are being reconciled and aligned with their past. The historic relationships of taonga to the culture and their connectedness to constructions of tribal identity are acknowledged, but is this helping to shape and inform the future development strategies of iwi?

\section{Background}

My research topic has emerged from my work at the National Museum of New Zealand Te Papa Tongarewa (Te Papa) over the last two decades and my close involvement in the affairs of my marae. During this time, I have experienced many kaupapa ranging from curating exhibitions, engaging with iwi on cultural heritage issues, participating in the return of Māori ancestral remains back to New Zealand and an active involvement in the bicultural development of the museum sector. Perhaps the most challenging and yet rewarding has been the interface between iwi and museums on taonga issues and the tensions that invariably arise between museum practices and Māori tribal values. I have tribal affiliations with Ngāti Kahungunu, Rongowhakaata, Ngāti Porou and Ngāi Tahu and I have been involved in projects concerning all of these tribes. Having this insider relationship while working for the National Museum has created interesting tensions and meaningful opportunities.

6 Tapsell, Paul. 1997. "The Flight of Pareraututu: An Investigation of Taonga from a Tribal Perspective". The Journal of the Polynesian Society no. 4 (106). 323-374.

7 Durie, Mason. 1998. Te Mana, Te Kawanatanga: The Politics of Māori Self-Determination. Auckland: Oxford University Press. 79. 
The Māori academic, museum professional and Te Arawa tribesman Paul Tapsell has written extensively about this interface. His disenchantment with museums and their colonial practices is well known, as he believes museum practice is often counter to Māori ways of knowing and being. ${ }^{8}$ Tapsell advocates for the recognition of the values of source communities and notes that New Zealand museums are at the crossroads on whether they are willing to share exhibitionary power with Māori communities. ${ }^{9}$ In adopting the writing of the Pacific historian Greg Denning and museum commentator Paul Williams, Tapsell writes about his tribal taonga Pukaki and its capture by both the Crown and the museum world: "Pukaki is a worthy metaphor of colonial capture, demonstrating the ongoing Treaty breach on the beach within the contact zone of museums." ${ }^{\prime 10}$ Iwi are increasingly entering the 'contact zone' of the museum in a more forthright manner in order to pursue particular objectives relating to their identity and their more pragmatic social and economic development aspirations.

Seeing the active development of iwi in respect of self-determination and self-management and the close relationship they have with their cultural estate has stirred my interest in seeing how museums might better assist iwi in their cultural heritage aspirations. My work at Te Papa has taken me throughout the world, visiting overseas museums and galleries and interacting with indigenous and First Nation peoples. These experiences have inspired me to examine key issues between museums and source communities and, in particular, Māori people and their relationship with their taonga. Being actively involved in Māori exhibitions and Māori cultural projects over a 20-year period has brought a heightened sense of respect for Māori material culture, and the culture that ultimately invests it with meaning and mana. It also made me think long and hard about the importance of culture and identity and the role that taonga play in the Māori world, both past, present and future.

The conceptual creation and development of the National Museum of the American Indian (NMAI) in Washington DC in 2004 involved a process that affirmed and empowered First Nation Peoples. NMAI Director Rick West openly embraced social inclusion and championed the 'outside-in ground-up' approach. To this end, West went outside the museum

Tapsell, 2011.

9 Ibid. 86-87. Tapsell equates the museum to that of an office with their notions of ownership and museum values while the tangata whenua have their own sense of belonging and indigenous values.

10 Ibid. 17. Tapsell refers to Clifford's concept of 'contact zone' that recognizes the authority of cultures opposed to the universalist collection of collections. 
for the authority to speak. The authority in West's view lay with the First Nation Peoples. This new reflexive anthropology and practice with resurgent indigenous movements has had a profound impact on museum practice throughout the world. It was these international and national initiatives that convinced me to look more closely at Māori tribal identity and development and to see what role Māori taonga played within the wider culture.

The right of Māori to access and speak about their taonga or treasures underpinned the wellknown Te Māori exhibition in the 1980s. Politically, this exhibition helped shape and influence 'cultural' change in museums in a period characterized by the establishment of the National Kohanga Reo Movement, the establishment of Kura Kaupapa, and the creation of the Māori Language Act and the Māori Language Commission. Certainly for museums in New Zealand it was a timely wakeup call and for Māori it was described as a're-awakening' and 'voyage of rediscovery'. We know that Māori didn't visit museums in large numbers as many were seen as 'cold' places and places that celebrated the effects of colonisation and western imperialism. Although museums did have relationships with Māori, these relationships were few in number and mainly with individuals and families, not tribal organisations or marae committees. ${ }^{11}$ The museum environment has for the most part been a contestable site for the politics of Māori tribal identity and self-determination. The process of restorative justice, reconciliation and healing is an important contemporary reality for many Māori as they embark on the journey to address historic grievances through the Waitangi Tribunal. Aligned with these claims is the development mode of iwi to provide a better life for their people. Taonga appear to be a common denominator. In a similar way to that of Butts in his research on Māori and museums, the context and underlying theme of this thesis is the recognition of mana; the mana of taonga, the mana of the people, the mana of the land, the mana of the culture. ${ }^{12}$

11 McCarthy, Conal. 2007. Exhibiting Māori: A History of Colonial Cultures of Display. Oxford and New York: Berg and Te Papa Press. McCarthy notes how important chiefs, such as Wi Tako Ngatata and Te Puni of Te Atiawa and Tamihana Te Rauparaha of Ngāti Toa, along with Māori politicians who sat in the House of Representatives including Wi Parata, Mokena Kohere, Wi Pere, Paikea and Hori Kerei Taiaroa, regularly visited the Colonial Museum in the late 1860s. He writes that up until the 1900 Māori made up a small but consistent audience.

12 McCarthy, Conal. 2011. Museums and Māori: Heritage Professional, Indigenous Collections, Currrent Practice. Wellington: Te Papa Press. 
What constitutes Māori tribal identity and development and the nature of taonga is central to this research. Māori tribes are entering a new phase of development and increasingly they are being expected to plan and care for the future wellbeing of their people. Balancing the economic and business affairs of the tribe with the social and cultural responsibilities is a reality that many tribes take seriously. Applying the business acumen to a cultural enterprise can create tension and conflict as some want to see more immediate benefits rather than merely growing the investments for the future.

\section{Literature review}

As part of this research, I completed a review into key bodies of writing related to the research question. The scope of the literature review, which ranges across museum studies, development studies, cultural studies and Māori studies, also extended to writing on Māori taonga and the relationships with museums and indigenous people, both within national and international contexts. This material was invaluable as important themes emerged from the literature that had direct relevance and a relationship to the study. At the end of this review, I present the key ideas emerging from the literature that will be employed in the analytical framework for this study.

\section{Museums and indigenous people}

Museum studies, or museology as it is sometimes referred to, is a discipline that looks at the history of museums and the politics and processes involved in their operations, including exhibitions and display, conservation, education and the engagement with their diverse communities. ${ }^{13}$ In more recent times, the museum discourse has extended to examining the relationships with source communities, including indigenous and First Nation peoples along with issues such as repatriation, governance and representation. Museums form an important part of society and have often been associated with power and politics, and colonialism. What emerges from the writing is an understanding of museums and how they are inextricably linked to class and power divisions, such as imperialism, and implicated in the government and state. Tony Bennett is a key writer on the history of museums and provides a detailed picture of how museums have transformed themselves through time and become bound up

13 See Corsane, Gerard. 2005. Heritage, Museums and Galleries: An Introductory Reader. London \& New York: Routledge; Crooke, Elizabeth. 2008. Museums and Community: Ideas, Issues and Challenges London \& New York: Routledge.; Macdonald, S, and G Fyfe. 1998. The Politics of Display: Museums, Science, Culture. London \& New York: Routledge.; Sandell, Richard. 2002. Museums, Society, Inequality. London \& New York: Routledge. 
with social relations, particularly questions of identity and diversity, by providing symbols and icons of culture and identity. ${ }^{14}$ Bennett argues that museums make nations, make peoples and make art. ${ }^{15}$ "Museums are socially and historically located," Macdonald reminds us, "and, as such, they inevitably bear the imprint of social relations beyond their walls and beyond the present." ${ }^{16}$ Certainly for Māori, the power that museums hold will be contested in their pursuit of self-determination and recognition.

There is a rich corpus of writing on the history of museums and the philosophy and theories that underpin them. ${ }^{17}$ From the nineteenth to the early twentieth century, colonial museums largely served the interests of the ruling elites by collecting treasures of peoples throughout the world and consolidating their knowledge and perceived authority and status, amassing large numbers of cultural treasures without a commensurate relationship with their descendant source community. It is no surprise then that museums have become key cultural loci of our times where questions are being asked about who they represent and the role they play. Long-held traditions and practices are being challenged and there is a renewed interest in what museums could or should be.

Museums are repositories of treasures from different cultures and peoples throughout the world. These treasures have for many different peoples now become vitally important in the restoration, maintenance and revitalization of their cultural identity and development aspirations. ${ }^{18}$ Many now argue that the contemporary role of museums is to recognize the vitality of living indigenous cultures and to be a platform for their future maintenance,

14 Bennett, Tony. 1995. The Birth of the Museum. London: Routledge.

15 Bennett, Tony. 2005. "Civic Laboraties: Museums, Cultural Objecthood, and the Governance of the Social". Cultural Studies no. 19 (5):521-547; Healy, C, and A Witcomb. 2006. South Pacific Museums: Experiments in Culture. Melbourne: Monash University ePress.

16 See Macdonald, Sharon, and Gordon Fyfe. 1996. Theorizing Museums: Representing identity and diversity in a changing world. Oxford, UK and Cambridge, USA: Blackwell Publishers. 4.

17 Barringer, T, and T Flynn. 1998. Colonialism and the Object: Empire, Material Culture and the Museum. London and New York: Routledge.; Bennett, Tony. 2004. Pasts Beyond Memory: Evolution, Museums, Colonialism. London \& New York: Routledge.; Genoways, Hugh H. 2006. Museum Philosophy for the Twenty-first Century Oxford, UK: AltaMira Press.; Hooper-Greenhill, Eilean. 2007. Museums and Education: Purpose, Pedagagy, Performance. London and New York: Routledge.; Sandell, 2002.

18 Clavir, M. 2002. Preserving What is Valued: Museums, Conservation, and First Nations. Vancouver: University of British Columbia Press.; Crooke, 2008. Peers, Laura, and Alison. K Brown. 2003. Museums and Source Communities: A Routledge Reader. London: Routledge.; Watson, Sheila. 2007. Museums and Their Communities. London \& New York Routledge. 
development and revitalization. ${ }^{19}$ In this new museum practice, as Kreps argues, community and identity are the central organizing concepts. ${ }^{20}$ In more recent times, indigenous peoples' voices and interests have also contributed to a better understanding of how heritage should be defined and its importance for the maintenance and ongoing development of cultural identity. It is this strand of writing, some of it within museum studies but also in indigenous studies, which provides the context for this research. In this thesis I seek to extend the analysis of the relationship between museums and source communities even further by looking at museums from the tribal community perspective.

The idea of museums and uncontested knowledge is common in the literature, and the new museum practice critically examines traditional museum practice that sees curators as fountains of knowledge and key interpreters. It is critical for museums to challenge themselves and to 'look behind forms to make indigenous values appear' ${ }^{21}$ and 'to prove we are not connected to the past only through myths and mementoes. ${ }^{22}$ This 'decentring' of curatorial practice and the sharing of power with respect to representation and interpretation has been an area of investigation for many writers. ${ }^{23}$ These writers champion the active involvement of communities in exhibitions, research projects and, for that matter, the wider business of museums. Their writing offers an important critique of so-called 'traditional' museum practice within the context of social inclusion and empowerment. This research takes this critique further by moving beyond an internal analysis of museums, instead examining them from the other side of the museum/community divide.

19 See Abungu, George H Okelo. 2006. “Africa and Its Museums: Changing of Pathways?”. In Art and Cultural Heritage: Law, Policy and Practice, edited by Barbara T Hoffman, 386-393. New York: Cambridge University Press.; Battiste, M. 2000. Reclaiming Indigenous Voice and Vision. Vancouver: University of British Columbia.; Hill, Richard. 2001. "Regenerating Identity: Repatriation and the Indian Frame of Mind". In The Future of the Past: Archaeologists, Native Americans and Repatriation edited by T.L Bray, 127-138. New York: Garland Publishers.; Stanley, Nick. 2007. The Future of Indigenous Museums: Perspectives from the Southwest Pacific. New York \& Oxford: Berghahn Books.; West, Rick. 2004. "As long as we keep dancing". In Spirit of a Native Place: Building the National Museum of the American Indian, edited by Duane Blue Spruce, 47-65. Washington: National Geographic Society.; West, Rick. 2005. "Cultural Futures." In The Native Universe and Museums in the Twenty-First Century, edited by Mark Hirsch and Amy Pickworth. Washington D.C., and New York: National Museum of the American Indian, Smithsonian Institution.

20 Kreps, Christina. 2003. Liberating Culture: Cross-Cultural Perspectives on Museums, Curation and Heritage Preservation. London \& New York: Routledge. 10, 44.

21 See Watson, 2007. (Original cited in Burgess in Bellaigue 1986).

22 Ibid. (original cited in Sola 1986, 57).

23 Ames, Michael. 1992. Cannibal Tours and Glass Boxes: The Anthropology of Museums. 2nd ed. Vancouver: University of British Columbia Press.; Gurian, Elaine. 1999. "What is the object of this exercise? A meandering exploration of the many meanings of objects in museums." Daedalus no. 128 (3):163-183.; Kreps, 2003. 
There is rich material in the literature to do with museums and indigenous peoples. ${ }^{24}$ These writers ask pertinent questions regarding the involvement of indigenous peoples not only in the business of exhibitions and collaborative research projects but also interrogate the museum's territory regarding interpretation, presentation and representation. Colonisation has had a marked and devastating effect on the lives of indigenous people ${ }^{25}$ and within this state the material culture can be seen as representing the lives and knowledge of ancestors and bridges to the future for the recovery of cultural knowledge, as Peers and Brown note:

\begin{abstract}
As 'sites of intersecting histories' (Edwards 2001:2), artefacts have overlapping, but different, sets of meanings to museums and source communities - and tend to be interpreted very differently by each group. Particularly for indigenous peoples, for whom the effects the efforts of colonization have produced rapid and wrenching change, museum artefacts represent material heritage and incorporate the lives and knowledge of ancestors. They are also crucial bridges to the future. For peoples whose way of life has changed dramatically but whose identity rests on historical cultural knowledge, artefacts offer the possibility of recovering a broad range of cultural knowledge for use in the present and future. ${ }^{26}$
\end{abstract}

The potential of museums as agents of change and for affecting transformation in contemporary communities is a strong theme that is emerging from the museum studies literature. Sandell, for example, has investigated the agency of museums and the museums' relationship to the outside communities, and points out that museums can make a difference in the lives of their contemporary communities. ${ }^{27}$ Sandell further says that: "This unique capacity opens both imagination and reality to greatly expanded roles for museums as agents of change and social inclusion, and to the undeniable potential of museums as therapeutic agents." 28 This transformational agency role of museums has been described by Weil as being

24 Clavir, 2002; Clifford, James. 1997. Routes: Travel and Translation in the Late Twentieth Century. Cambridge: Harvard University Press.; Conaty, Gerald T. 1989. "Canada's First Nations and Museums: A Saskatchewan Experience". The International Journal of Museum Management and Curatorship no. 8 (4):407-413.; Healy and Witcomb, 2006; Karp, Ivan, and Steven. D Lavine. 1991. Exhibiting Cultures: The Poetics and Politics of Museum Display. Washington: Smithsonian Institution Press.; Knell, Simon J. 2007. Museums in a Material World. London \& New York: Routledge.; Knell, Simon J, Suzanne Macleod, and Sheila Watson. 2007. Museum Revolutions: How Museums Change and are Changed. London and New York: Routledge.; Simpson, Moira G. 1996. Making Representations: Museums in the Post-Colonial Era. London \& New York: Routledge.; Stanley, 2007.

25 See Helin, Calvin. 2006. Dances with Dependency: Out of Poverty through Self-Reliance. California: Ravencrest Publishing.

26 Peers and Brown, 2003. 5.

27 Sandell, 2002. 18.

28 Ibid. 81. 
a shift from being about something to being for somebody. ${ }^{29}$ For Lonetree, there are transformational qualities in decolonizing and indigenizing museums from sites of harm into sites of healing and community wellbeing. ${ }^{30}$

The establishment of cultural centres and tribal museums is not new and Stanley notes the importance of living cultures in the South Pacific. ${ }^{31}$ Stanley looks to the future of museum practice by examining how museums have evolved to incorporate the present and future in the display of culture. Stanley also introduced themes like indigenous curatorship, management and self-determination in his writing. These are important considerations for indigenous and First Nation peoples as they provide pathways on which indigenous people can further develop, as well as helping to expand museum practice for the future.

The definition of a museum and what constitutes its role and function in modern times is clearly being challenged and contested as communities call for greater engagement and involvement in its affairs for their own development of identity and history. ${ }^{32}$ Certainly the importance of community to museums has taken on new significance and meaning in more recent times. Writers like Kreps, Crooke and Sandell write about the museum's responsibilities to encourage the learning of their own histories and the contemporary significance of them. ${ }^{33}$ These writers believe the role that museums can play at a societal level is based on the notion of culture as generative in working with different communities. As Kreps says:

The new museology is largely about giving people control over their cultural heritage and its preservation as part of how they maintain, reinforce, or construct their identity. The approach acknowledges the importance of preserving not only the resources that represent a community's past, but also vital elements of its living culture and its continuing development. ${ }^{34}$

Crooke writes about the importance of understanding communities and the diversity of engagement, with an acknowledgement that museums can be more relevant in helping communities to achieve greater social equality and community regeneration:

29 Weil, Stephen E. 2002. Making Museums Matter. Washington D.C.: Smithsonian Institution Press. 29.

30 Lonetree, Amy. 2012. Decolonizing Museums. Representing Native America in National and Tribal Museums. Chapel Hill: The University of North Carolina Press. 173.

31 Stanley, 2007.

32 Kreps, 2003; Peers and Brown, 2003; Sandell, 2002.

33 See Kreps, 2003; Crooke, Elizabeth. 2006. "Museums and Community". In A Companion to Museum Studies, edited by Sharon Macdonald, 171-185. Oxford: Blackwell Publishing.; Crooke, 2008; Sandell, 2002.

34 Kreps, 2003. 10. 
Gathering pace over the past decade, museums have now become a means to reach some of the goals of community development, such as encouraging participation of the marginalized and excluded, promotion of opportunities for self-help, and a means to bring about changes that can lead to greater social equality. ${ }^{35}$

My research theoretical framework recognises the rationale and perspective of these writers and adopts a similar way of thinking about cultural heritage and the relationship to its source community in its ongoing development.

\section{Museums and source communities}

The literature on museums and source communities has been an area of increased interest over the last decade. Of particular value has been the writing of Peers and Brown, ${ }^{36}$ Crooke $^{37}$ and Watson. ${ }^{38}$ These writers have provided invaluable research and rich perspectives on community involvement and engagement, including areas such as social inclusion, democratisation and the moral and legal rights of communities in general, and indigenous people in particular, to access their cultural treasures. They also directly address new developments in museum practice, including collaborative research projects with museums and their source communities, the cultural needs and aspirations of source communities, and the desire for the development of what is described as a new 'curatorial praxis'.

The need to connect and reconnect museums with their source communities is becoming a vital dimension for the legitimacy of museums and an important area in more recent research in Museum Studies. ${ }^{39}$ Peers and Brown argue that creating relationships is a vital area that has not received much attention in the critical literature, along with source communities and their relationships to their material culture:

These relationships are the most important manifestation of the new curatorial praxis, but the process of establishing them has not received much attention in the critical literature. Nor has the concept of 'source community' and its special needs in and rights to material heritage held in museum collections been a focus in the literature. ${ }^{40}$

The importance of cultural treasures to their communities is aptly stated by Peers and Brown when they say:

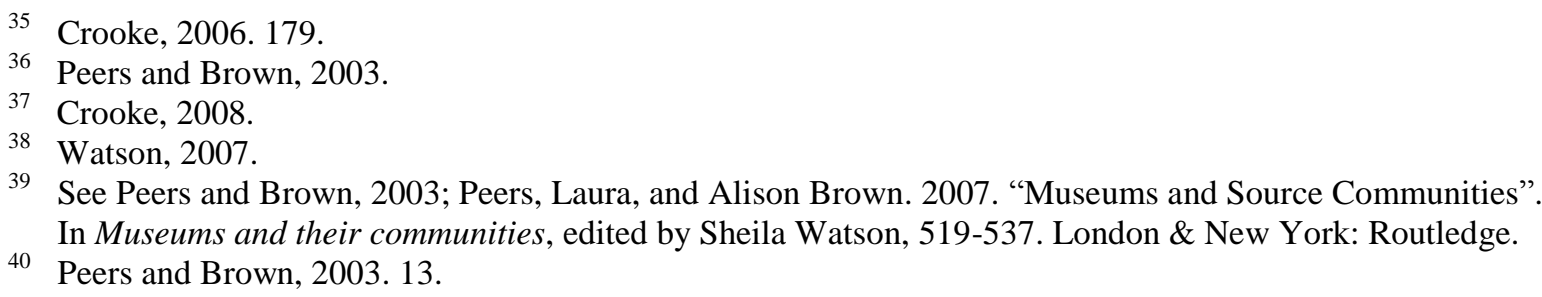


Most importantly, the concept recognises that artefacts play an important role in the identities of source community members, that source communities have legitimate moral and cultural stakes or forms of ownership in museum collections, and that they may have special claims, needs, or rights of access to material heritage held by museums. In this new relationship, museums become stewards of artefacts on behalf of source communities. They are no longer the sole voices of authority in displaying and interpreting those objects, but acknowledge a moral and ethical (and sometimes political) obligation to involve source communities in decisions affecting their material heritage. ${ }^{41}$

The former Director of the National Museum of the American Indian, Rick West, describes the importance of source communities and the native way of viewing objects, including the spiritual dimension, the primacy of process and the different paradigm of the western knowledge tradition. ${ }^{42}$ West describes this as 'in-reach' as opposed to 'out-reach'43 and says that a critical part of this is the recognition of the living culture:

First, while acknowledging our deep past, Native peoples want to be seen as communities and cultures that are very much alive today. Second, we want the opportunity to speak directly to museum visitors through our exhibitions and public programs, and to describe in our own voices and through our own eyes the meanings of the objects in the museum's collections and their importance in Native art, culture, and history. And third, we want the museum to act in direct support of contemporary Native communities. $^{44}$

The writing on museums and source communities is directly relevant to my research question as it recognises the importance of cultural heritage in the lives of source communities and by association the critical importance of relationships for both museums and their communities. This context has been described by James Clifford as 'contact zones' which refers to "a space in which peoples geographically and historically separated come into contact with each other and establish ongoing relations. ${ }^{" 45}$ Clifford described a consultation session with a First Nation group that went wrong. The museum's agenda was to gain knowledge while the First Nation group's expectation was something quite different. For Clifford "Artefacts function as 'contact zones' - as sources of knowledge and as catalysts for new relationships - both within and between these communities" ${ }^{46}$ Clifford notes the importance of 'contact zones' as a way that recognizes the authority of cultures as opposed to the universalist collections of culture:

41 Ibid. 2.

42 West, Rick. 2004. "The National Museum of the American Indian: Steward of the Sacred". In Stewards of the Sacred, edited by Lawrence E Sullivan and Alison Edwards, 7-17. American Association of Museums in co-operation with the Center for the Study of World Religions, Harvard University. 9.

43 Ibid. 15.

44 West, 2004. 56.

45 Peers and Brown, 2003. 5.

46 Ibid. 
Clifford argues that thinking of museums as contact zones provides a way of understanding, and addressing, the concerns of contemporary indigenous peoples. As long as museums are thought of 'as collections of universal culture, repositories of uncontested value, sites of progress, discovery, and the accumulation of human, scientific, or national patrimonies', that is, as end products of witnesses of colonial achievement, we will continue to marginalize non-Western peoples and deny them agency and legitimacy in the past and the present. ${ }^{47}$

Collaborations between museums and artists and ethnographic museums have also increased in recent times ${ }^{48}$ but arguably this also needs to be expanded and further developed to understand the processes and reasons why this is happening across a much greater range of material culture and a greater variety of museums, not just art.

A lot of the writing regarding exhibitions emphasizes the object as the central focus within the context of exhibitions and programmes. ${ }^{49}$ In terms of the interaction and relationship between museums and indigenous peoples, the literature has tended to focus mainly on collaborative exhibition partnerships and mutual research partnerships. ${ }^{50}$ This area has been written about over the last 20 years, but a lot more critical research is required given that museums are involving source communities and indigenous peoples far more, and that these collaborations extend beyond objects themselves. Furthermore, much of the current literature is limited to museum-initiated projects, looking at communities from within museums, not from the outside in terms of community objectives and how museums can support those.

Writers such as Stanley, Healy and Witcomb, and Knell, Macleod and Watson ${ }^{51}$ have discussed the future of museum practice by looking at how museums have evolved to incorporate the present and future in the display of culture. These writers have also explored the ways in which museums are being shaped and configured and how they themselves attempt to shape and change the world around them. However, this literature is again largely

47 Ibid. 20. (Original reference cited in Clifford, 1997, 213).

48 Corin, Lisa G. 1994. Mining the Museum: Artists look at museums, museums look at themselves. New York: The New Press.; Raymond, Rosanna, and Amiria Salmond. 2008. Pasifika Styles: Artists Inside the Museum: University of Cambridge Museum of Archaeology and Anthropology, Cambridge, in association with Otago University Press.

49 Pearce, Susan. 1994. “Objects as meaning: or narrating the past”. In Interpreting objects and collections, edited by Susan Pearce, 19-29. London \& New York: Routledge.

50 Abungu, 2006; Ames, 1989; Ames, Michael. 2003. "How to decorate a house: The re-negotiation of cultural representations at the University of British Columbia Museum of Anthropology". In Museums and Source Communities: A Routledge Reader, edited by Laura Peers and Alison K Brown, 171-180. London \& New York: Routledge.; Peers and Brown, 2003; Carter, John. 1994. "Museums and Indigenous Peoples in Canada". In Museums and the Appropriation of Culture, edited by Susan Pearce, 213-226. London: Te Athlone Press.; Casey, Dawn. 2001. "Museums as Agents for Social and Political Change." Curator, no. 44 (3):230-236.; Conaty, 1989.

51 See Stanley, 2007; Healy and Witcomb, 2006; Knell, Macleod and Watson, 2007. 
limited to museum futures, not cultural futures of source communities. Yes, museums must change to adapt to society, but this research explores how museums might be re-directed to serve the needs of tribal people who appear to be going off in other directions.

Over the last 30 years there have been attempts to involve indigenous peoples and native peoples more in the operation of the museum. A rich resource of material in the literature is the writing to do with museums and indigenous peoples. ${ }^{52}$ These writers ask pertinent questions regarding the involvement of indigenous peoples, not only in the business of exhibitions and collaborative research projects but also interrogate the museums' territory regarding interpretation, presentation and representation. One area where this happened has been the traditional care practices of First Nation and indigenous people's collections. ${ }^{53} \mathrm{~A}$ growing number of indigenous writers have emerged that challenge Eurocentric and colonial museum thinking and imagining. ${ }^{54}$ However, the area of museums and First Nation and indigenous peoples has not received much attention in the literature and, in fact, there is a drastic shortage of First Nation and indigenous people writing with respect to museums and relationships established with them. This research will help fill this gap in the literature. Collaborative exhibitions that reflect partnership with inclusion and full participation have been documented along with the recognition of First Nation knowledge and cultural practices. ${ }^{55}$

The writing on repatriation by indigenous people has likewise been an area of inquiry ${ }^{56}$ and for Hill repatriation is about reconnection and regenerating identity: "Repatriation became the

52 See Clavir, 2002; Clifford, 1997; Conaty, 1989; Healy and Witcomb, 2006; Karp and Lavine, 1991; Knell, Macleod and Watson, 2007; Simpson, 1996; Stanley, 2007.

53 Rosoff, Nancy. 2003. "Integrating Native Views into Museum Procedures: Hope and Practice at the National Museum of the American Indian". In Museums and Source Communities: A Routledge Reader. 72-80. New York: Routledge.; Sullivan, Tim, Lynda Kelly, and Phil Gordon. 2003. "Museums and Indigenous People in Australia: A Review of Previous Possession, New Obligation: Policies for Museums in Australia and Aboriginal and Torres Strait Islander Peoples". Curator no. 42 (2):208-227.

54 Battiste, 2000; Casey, 2001; Conaty, Gerald T. 2003. "Glenbow's Blackfoot Gallery". In Museums and Source Communities: A Routledge Reader, edited by Laura Peers and Alison K Brown, 227-241. London \& New York: Routledge.; Conaty, Gerald T. 2008. "The effects of repatriation on the relationship between the Glenbow Museum and the Blackfoot People”. Museum Management and Curatorship no. 23 (3):245-259.; Crooke, Elizabeth. 2005. "Museums, communities and the politics of heritage in Northern Ireland". In The Politics of Heritage: The legacies of 'Race', edited by Jo Littler and Roshi Naidoo, 237-255. London: Routledge.; Hill, Richard W. 2000. "The Museum Indian: Still Frozen in Time and Mind". Museum News no. 79 (3):40-44.; Hill, 2001; Smith, Linda Tuhiwai. 1999. Decolonizing Methodologies: Research and Indigenous Peoples. Dunedin/London/New York: University of Otago Press/Zed Books Ltd.; West, Rick. 2004. The Changing Presentation Of The American Indian. Washington: University of Washington Press.

55 See Conaty, 2003, 2008; Hill, 2000.

56 See Conaty, 2008; Hill, 2001; Hill, Richard. 2007. "Regenerating Identity: Repatriation and the Indian Frame of Mind". In Museums and their communities, edited by Sheila Watson. London \& New York: Routledge. 
process through which we sought to reconnect with the ideals represented in those objects and reclaim authority over them." 57 These writers champion what has been described as the post-colonial discourse aiming to advance the struggle for political and cultural change and restore the health, vitality and meaning of indigenous thinking and imagining. Rick West, for example, writes about native First Nation peoples saying that they have fought hard to be here and insisting on some kind of cultural future in the northern hemisphere. ${ }^{58}$

Engaging indigenous people over and above the exhibition arena and more in the business of a museum's activities is an important dimension that some leading museum commentators and writers have advocated. ${ }^{59}$ Some commentators advocate that the relationship between museums and indigenous people should go well beyond mere collaboration, as Gurian notes:

The exclusive right of museum personnel to decide what shall be included or excluded in their public exhibitions will, and in some cases already has, ended. The display of any objects without consultation with the native group and, by extension, any group importantly affected, will become obsolete. In fact, the involvement of indigenous peoples in the business of museums goes much deeper than mere presentation. ${ }^{60}$

The liberation of indigenous peoples from their 'oppression' and colonial experience is well represented in the literature, but only a few writers have begun to consider how the museum might help people to 'liberate' their culture. ${ }^{61}$ Kreps and Nicks express this as the liberation of culture from the management regimes of Eurocentric Museology with the restoration of people's rights to the control and management of their own cultural heritage. ${ }^{62}$ Kreps further notes that "it is no longer sufficient to treat indigenous objects as inert relics" and that "taking account of indigenous practices and interests serves to decentre the dominance of scientifically based museology." Kreps acknowledges the strong connection and relationship between material culture and people's cultural identities and argues for giving greater control to people of their material culture so that they can themselves maintain and develop their cultural identities. For Kreps, community and identity are central organizing concepts in the new museum practice and preserving the past, as well as looking after the vital elements of its

57 Hill, 2007, 315.

58 West, 2005. 9.

59 Ames, 1989, 1999; Gurian, Elaine. 2006. Civilizing the Museum: The Collected Writings of Elaine Heumann Gurian. London and New York: Routledge.; West, Rick. 1993. "The New Inclusiveness". Anthropology News no. 34 (2): 39-40.; West, 2005.

60 Gurian, Elaine. 2005. “A Blurring of the Boundaries”. In Heritage, Museums, and Galleries: An Introductory Reader, edited by G Corsane, 71-77. New York: Routledge. 74.

61 Battiste, 2000; Simpson, 1996; Smith, 1999.

62 Kreps, 2003, 10; Nicks, Trudy. 2003. "Museums and Contact work: Introduction”. In Museums and Source Communities, edited by Laura Peers and Alison Brown, 19-27. 
living culture and continuing development, is paramount. ${ }^{63}$ This writing is important for my research as it signals the significance of identity and development through the agency of Māori material culture.

Important for this research is what Kreps describes as championing the growing importance of culture-based approaches to community development and the role museums play in this culture as a foundation to development. ${ }^{64}$ This is a critical statement that speaks directly to my research, as Māori tribes are increasingly seeing museums as potential places to aid and assist Māori tribal development, given that they hold tribal taonga. The culture-based approaches to community development speak directly to self-determination and the tribes' self-management strategies for the present and future.

The museum commentator Moira Simpson is a major contributor to this discussion and has examined how western museums have reacted to and addressed issues of cultural representations in museums and how they have formed new relationships with indigenous communities. ${ }^{65}$ Simpson recognizes the contemporary value of heritage for living cultures and the link between heritage and health and wellbeing. Simpson writes about the restoration of key items of cultural and spiritual heritage to living cultures and how these align with recent UNESCO conventions designed to promote recognition and protection of cultural diversity, intangible heritage and the rights of indigenous peoples. ${ }^{66}$

Like the well-known Māori academic and cultural theorist on decolonizing methodologies Linda Smith, Simpson also asks for the re-socialization of objects and their return to their place of origin where they may stimulate the values of heritage for living cultures. ${ }^{67}$ Simpson argues that this dimension emphasizes the importance of material culture for intergenerational knowledge transmission within indigenous communities and in the preservation and renewal of the intangible aspects of cultural heritage. ${ }^{68}$

The contemporary role of museums to recognize the vitality of living cultures and to be a platform for their future development and revitalization is a key driver for many indigenous

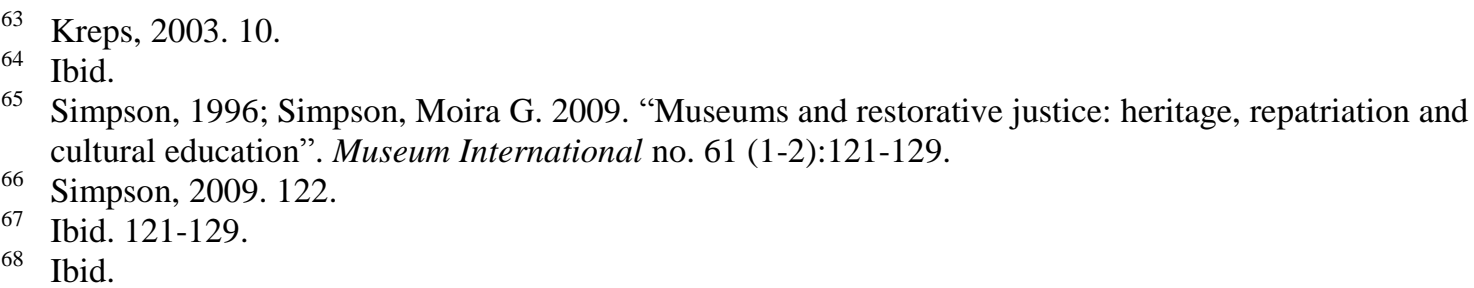


peoples. ${ }^{69}$ My research has investigated this living dimension and proposes that the new museum practice gives people control over their cultural heritage and its preservation as part of how they maintain, reinforce or construct their identity.

\section{Repatriation and museums}

One of the strongest words in museum circles that always evokes great debate and emotion is 'repatriation'. Of all the words and concepts associated with museums and galleries, it is this word alone that brings out the historical and contemporary tensions, contradictions, ambivalences and anger between indigenous and First Nation peoples and museums. If one was to scan the literature for example or do a Google search under 'museum repatriation', this would return 766,000 hits. $^{70}$ Over the last 20 years there has seen an explosion of activity and change in museums, reflecting not only the change in enlightened museum practice but, just as importantly, the reaffirmation of indigenous peoples' rights to their cultural heritage material.

Repatriation is not only the hot topic of conferences and symposia but also today its global reach has extended to a federal law, international instruments and accords, and government policies and practices. The literature has likewise increased with repatriation often being a topic of discussion and debate in the print media of museum studies, cultural studies and indigenous peoples' studies. Reconciling past museum practice to meet the challenges and expectations of modern society is a strong focus and theme of the literature on museums and repatriation. In America, for example, we have the federal law, the Native American Graves Protection and Repatriation Act (NAGPRA) that was passed in $1990 .{ }^{71}$ In Australia there is the Museums Australia Policy of 'Continuing Cultures, Ongoing Responsibilities' 2005 (formerly Previous Possessions, New Obligations) that provides principles and guidelines for Australian museums working with Aboriginal and Torres Strait Islander cultural heritage. ${ }^{72}$ Other nation states have their own policies and practices concerning repatriation.

69 Abungu, 2006; Battiste, 2000; Hill, 2001; Stanley, 2007; West, 2004, 2005.

70 Google search of the term 'museum repatriation' carried out on $3^{\text {rd }}$ May 2010.

71 See Trope, J. and W. Echo-Hawke. 2000. "The Native American Graves Protection and Repatriation Act: Background and Legislative History”. In D. Mihesuah (Ed.), Repatriation Reader: Who Owns American Indian Remains? 123-168. Lincoln: University of Nebraska Press.

72 'Previous Possessions, New Obligations' was launched in 1993 with a major review in 2000. The new policy titled 'Continuing Cultures, Ongoing Responsibilities' was relaunched in 2003. See Dolan, Janey. 2001. "Previous Possessions New Obligations in Western Australian Community Museums". Open Museum Journal 3. hrrp://amol.org.au/craft/omjournal/volume3/dolan.pdf.; Griffin, D. "Previous Possessions, New Obligations: A Commitment by Australian Museums”. Curator 39, no. 1 (1996): 45-62. 
There has been a growing trend by indigenous and First Nation peoples throughout the world to reclaim their cultural treasures held in museums to restore and revitalise their cultural identity, language and traditions. Repatriation, however, has often met with fear and trepidation, as Nicks notes: "Reconciling issues of ownership represents a complex and difficult part of contact work," he writes. "The first reaction of museums to challenges from indigenous communities has often been fear that mainstream museums would lose the right to hold or exhibit indigenous materials.",73

The repatriation strategies by indigenous people are aimed towards self-determination and for museums this means a new way of thinking, planning and acting that is different from the colonial western paradigm. As stated by Butts:

The common element in the repatriation strategies presented in this section is that each one enables or asserts a degree of self-determination for the indigenous peoples involved. These strategies also demonstrate the ability of indigenous people to shift the site of resistance and negotiation in order to align their cause with broader issues of human rights or, more specifically, indigenous rights. In order to respond effectively in this evolving environment, where indigenous peoples are reconnecting with their cultural property in museum collections and asserting their rights in relation to these collections, many museums have realised that they must move beyond the colonial paradigm that has determined their relationships with indigenous peoples. ${ }^{74}$

Significant with these instruments of indigenous recognition is the acknowledgement and recognition of primary rights of indigenous peoples in the management and interpretation of their cultural material held in museum collections. This also includes access and ownership of ancestral remains. Repatriation is of particular relevance to my research question, as the pursuit of a secure Māori identity includes access to language and knowledge; access to culture and cultural institutions, such as marae; access to Māori economic resources, such as land, forests, fisheries; and access to social resources such as whānau. ${ }^{75}$

What does emerge from the repatriation literature is the importance of relationships and the connection to culture and identity. ${ }^{76}$ As Richard Hill reminds us: "Repatriation is not an end; it is, in many ways, a new beginning. Through the processes and relations it engenders,

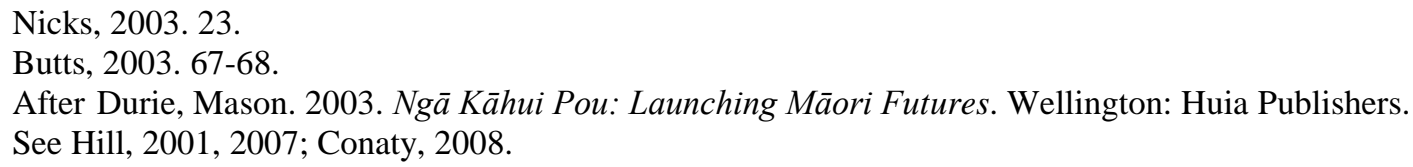


museums will come to understand that cultural preservation is not only about keeping objects from decaying but also about keeping ideas, values, and beliefs viable for the many generations to come.",77

Repatriation can be seen as a futures-oriented solution to cultural restoration and revitalisation. The act of returning and reconnecting is as vital to a secure Māori identity as it is to securing a good museum future. This thinking of cultural continuity and living cultures resonates with a number of writers. ${ }^{78}$ My research interrogates this positioning by examining tribal cases studies and taonga projects.

\section{New Zealand Museums}

There is a history of New Zealand Māori and Pākehā writing about New Zealand museums and the working relationships between Māori and museums in particular. ${ }^{79}$ David Butts and Conal McCarthy provide recent syntheses important to the work of those who have made significant contributions, especially since the 1970s when museum practitioners and Māori scholars and others enjoyed critical dialogues.

In New Zealand's context, the history of museums and museum practice has its roots and foundations in the western tradition. From imperial expansion through to the rapid colonisation of lands and nations in New Zealand, museums have been seen as colonial constructs with demonstrable western ways of knowing and being. ${ }^{80}$ Museum practice in New Zealand is now well known largely through the writings of David Butts and Conal

77 Hill, 2007. 323.

78 Hill, R. Sr. 1994. "Repatriation: an opportunity for cultural exchange”. American Indian Object Repatriation Foundation News \& Notes no. 1(1) (Spring). Hill, 2001, 2007; Nicks, 2003; Simpson, 1996.

79 Butts, David. 2002. "Māori and Museums: The Politics of Indigenous Recognition". In Museums, Society, Inequality, edited by Richard Sandell, 225-243. London \& New York: Routledge. Butts, David. 2003. Māori and Museums: The Politics of Indigenous Recognition. PhD, Museum Studies, Massey University, Palmerston North.; Hakiwai, Arapata. 1988. "Museums as Guardians of our Nations Treasures". AGMANZ Journal no. 19.2 (2):35-38.; Hakiwai, Arapata. 2005. "The Search for Legitimacy: Museums in Aotearoa, New Zealand - A Māori Viewpoint”. In Heritage, Museums and Galleries: An Introductory Reader, edited by Gerard Corsane, 154-162. London \& New York: Routledge.; Hakiwai, Arapata. 2006. "Māori Taonga Māori Identity". In Art \& Cultural Heritage: Law, Policy and Practice, edited by Barbara.T Hoffman, 409412. New York: Cambridge University Press.; McCarthy, 2007, 2011; Mead, H M. 1984. Te Māori: Mãori art from New Zealand Collections. New York and Auckland: Heinemann. American Federation of Arts.; Mead, Sidney. 1993. "The Maintenance of Heritage in a Fourth World Context: The Māori Case”. In Artistic Heritage in a Changing Pacific, edited by Dark, Phillip and Rose Roger, 223-231. Honolulu: University of Hawai'i Press.; Tapsell, Paul. 1998. Taonga: A Tribal Response to Museums. PhD School of Museum Ethnography, University of Oxford, London.; Tapsell, Paul. 2011. The Art of Taonga. Wellington: Art History, Victoria University of Wellington.; Thompson, Keith W. 1981. Art Galleries and museums in New Zealand. Wellington: Reed.

80 Henare, Amiria. 2005. Museums, Anthropology and Imperial Exchange. Cambridge: Cambridge University Press. 
McCarthy ${ }^{81}$ Their publications speak to the history, philosophy and varied nature of museums in New Zealand. Butts also remind us that public museums in New Zealand were established to accommodate the collections of indigenous peoples and that this was an integral part of the colonizing process. ${ }^{82}$

\section{Museums and Māori}

This literature on museums and Māori has increased in the last few decades along with the examination of museums and their relationships with Māori. ${ }^{83}$ The main writers in particular that have documented the history of Māori and museums in New Zealand have been Thompson, McCarthy and Butts. ${ }^{84}$ These academics have examined the history of museum practice in New Zealand, the governance relationships of key regional and metropolitan museums, the genealogy of exhibiting Māori, through to case studies that look at exhibitions and iwi projects.

McCarthy's seminal publication details the genealogy of exhibiting Māori, including case studies that look at exhibitions and iwi projects. McCarthy also notes the lack of historical and theoretical analysis given in these museums to iwi relationships. ${ }^{85}$ Informative about the research is what McCarthy refers to as the 'revisionist history of indigenous interaction with museums ${ }^{86}$ where there is a denial of Māori agency at the expense of over-determining the colonial encounter.

Butts highlights the depth of the relationships between Māori and museums and provides new insights into governance relationships between Māori and museums, revealing a complexity

81 Butts, 2002; Butts, 2003.; Butts, David. 2007. "Māori, Museums, and the Treaty of Waitangi: The Changing Politics of Representation and Control". In Museum Revolutions: How Museums Change and Are Changed, edited by Simon J Knell, Sheila Watson and Suzanne Macleod, 215-227. London: New York: Routledge.; McCarthy, Conal. 2004. From Curio to Taonga: A genealogy of display at New Zealand's National Museum, 1865-2001. PhD, Museum \& Heritage Studies, Victoria University, Wellington.; McCarthy, Conal. 2009. "Post-colonial Pasts and Post-indigenous Futures: A Critical Genealogy of 'Māori art"'. In Crossing Cultures: Conflict, Migration and Convergence. The Proceedings of the 32nd International Congress in the History of Art, edited by Jaynie Anderson, 803-808. Melbourne: The Miegunyah Press.

82 Butts, 2003, 1. Many museums were created during the time of the New Zealand Wars - Auckland (1862), Taranaki (1865), Hawke's Bay (1865), Wellington (1865), Otago (1868) and Canterbury (1870).

83 Butts, 2000, 2003, 2007; Cameron, F. 2000. Shaping Māori Identities and Histories: Collecting and Exhibiting Māori Material Culture from the 1850's to the 1920s. PhD, Social Anthropology, Massey University, Palmerston North.; McCarthy, 2004, 2007; Tapsell, 1998; Tapsell, Paul. 2006. Ko Tawa: Māori Treasures of New Zealand. Auckland: David Bateman Ltd.

84 See Thompson, 1981; McCarthy, 2004, 2007; Butts, 2002, 2003; Butts, David. 2006. "Museum Governance, Indigenous Recognition and (in) Tolerant Multiculturalism.” New Zealand Sociology, no. 21 (no.1):89-107.

85 McCarthy, 2007, 11.

86 McCarthy, 2011. 
and continuity of relationships over time. ${ }^{87}$ His close examination of the governance arrangements with six regional museums, including the Tairāwhiti Museum and the Whanganui Regional Museum, has impacted significantly on indigenous peoples and their cultural heritage and, as Butts reminds us, museums have been the gatekeepers of culture and in control of Māori material culture for a long time. They have played their part in the colonisation process in New Zealand where they have collected and interpreted Māori cultural treasures without forming close relationships with the iwi (tribes) who had originally owned the collections. ${ }^{88}$ These two writers have been very influential in bringing to the fore important historical and contemporary dimensions of museum practice in New Zealand.

Much has been written about museums and Māori over the last 30 years and these contributions add immensely to the literature and research. The governance in museums has been a recent area of research ${ }^{89}$ along with the involvement of Māori in museums. ${ }^{90}$ A survey of the literature tells us of the importance that this area has had over the last 20 years. ${ }^{91}$

Sid Mead's writing in the 1980s to 1990s still remains one of the most influential and relevant with regard to Māori art, Māori self-determination and Māori-museum relationships. His publications on the Te Māori exhibition, along with his article titled 'The Nature of Taonga' remain key academic texts for students studying Māori art and museum studies. As Mead says with respect to Māori identity: "The importance of korero associated with taonga, for example, not only provides meaning and cultural significance but more importantly links

87 Butts, 2002, 2003, 2007.

88 Butts, 2002. 225.

89 Butts, 2000, 2003, 2006; Kawharu, Merata. 2002. "Indigenous Governance in Museums: A Case Study, The Auckland War Memorial Museum”. In The Dead and their Possessions: Repatriation in Principle, Policy and Practice, edited by Fforde Cressida, Jane Hubert and Paul Turnbull. London: Routledge.; Tapsell, Paul. 2003. "Beyond the Frame: An Afterword". In Museums and Source Communities: A Routledge Reader, edited by Laura Peers and Alison K Brown, 242-251. London \& New York: Routledge.; Tapsell, 2006.

90 Butts, 2002, 2003; McCarthy, 2004; McCarthy, Conal. 2005. 'Objects of Empire? Displaying Māori at International Exhibitions, 1873-1924”. Journal of New Zealand Literature: Special Issue no. 23 (1):52-70.; McCarthy, 2007.

91 See Brown, Deidre. 2003. Tai Tokerau Whakairo Rākau: Northland Māori Woodcarving: Reed Publishing.; Davidson, Janet 1989. Taonga Māori: A Spiritual Journey Expressed through Māori Art. Wellington: Te Papa Press.; Mead, 1984; Mead, Sidney (Hirini) Moko. 1986. Magnificent Te Mãori: Te Mãori Whakahirahira. Auckland: Heinemann.; Mead, Sidney (Hirini) Moko. 1990. The Nature of Taonga. Paper read at Taonga Māori Conference, New Zealand, 18-27 November 1990, 1991, at Wellington.; Neich, Roger. 2001. Carved Histories: Rotorua Ngāti Tarawhai Woodcarving. Auckland: Auckland University Press.; Starzecka, Dorota. 1998. Māori Art and Culture. 2nd ed. London: The British Museum Press.; Tapsell, 1996. “Taonga and Obligations of Reciprocity”. New Zealand Museums Journal no. 26 (1):26-29.; Tapsell 1997, 1998; Tapsell, Paul. 2000. Pukaki: A Comet Returns. Auckland: Reed. Tapsell, Paul. 2006. "Taonga, Marae, Whenua - Negotiating Custodianship: A Māori Tribal Response to the Museum of New Zealand." In Rethinking Settler Colonialism, edited by A.E Coombes, 86-99. Manchester: Manchester University Press.; Whaanga, Mere. 2004. A Carved Cloak for Tahu. Auckland: Auckland University Press. 
it to a social group." 92 In the catalogue of the Te Māori exhibition, Sid Mead wrote that the carvings on display in museums were taonga which were given life and meaning by 'kupu' or words. When Māori view and respond to these taonga they are animated by the 'korero', the talk or language which surrounds and 'clothes' them, gives them meaning and value for the people. ${ }^{93}$ Throughout this thesis I return to the importance of the language used by Māori spokespeople when referring to the cultural, social and economic significance of taonga tuku iho.

Sid Mead was highly critical of museum practice in New Zealand and argued that Māori must reclaim the language of definitions and take back control of what was Māori. Mead's wellknown quote for the reclamation of Māori taonga remains as relevant today as it was 20 years ago:

One way of recapturing one's culture is to take control of the language of definitions and descriptions and to have members of the culture speak for themselves, present their culture such as their music, their dances and their various art forms in a manner they consider appropriate to them. ${ }^{94}$

Māori leaders like Sid Mead and Tipene O'Regan have had a continuous involvement in Māori arts and their tribal affairs. O'Regan was a council member of the National Museum in the 1980s to 1990s and has written extensively on Māori art issues, including an article on the Māori control of Māori heritage. In discussing the proprietorship of Māori taonga during the Te Māori exhibition, O’Regan warned that the increased perception of their past and heightened sense of self-esteem would lead to louder calls by Māori for their Māori material culture:

Phenomena such as the 'Te Māori' exhibition enormously enhance the Māori perception of their past and therefore their self-esteem. That process heightens the awareness of distance and tauiwi (outsider) control. The more status is heaped on their treasures, the more distant they become from the descendants of those who shaped and wove those treasures. This process has led to increasing calls for the withdrawal of taonga from museums and their return to the marae, to louder cries for Māori control and Māori interpretation. Greater awareness brings with it a more confident assertion of Māori proprietorship of Māori heritage. It's going to be a difficult decade for museums. ${ }^{95}$

92 Mead, H M. 1992. "The nature of taonga". In Taonga Māori Conference Proceedings, New Zealand, 17-27 November 1990, edited by Mark Lindsay, 164-9. Wellington: Department of Internal Affairs.; Mead, S.M., 1990.

93 Mead, 1984. 21.

94 Mead, 1990, 165.

95 Butts, 2003. 91. (Original reference cited in O’Regan, 1987, 144.) 
Other Māori commentators have also contributed to the discussions written about the relationships between museums and Māori, ${ }^{96}$ such as Arapata Hakiwai who says: "Museums are cultural constructs reflecting the traditions and practices that gave rise to them and the constructions of meanings by those who develop them and work within them." ${ }^{\text {"97 Hakiwai }}$ helped lead the restoration of the Ruatepupuke carved meeting house in the Field Museum in Chicago in the early 1990s and wrote about the need to 'work together but understand each other. ${ }^{98}$ Gerard O'Regan's survey in the mid-1990s also contributed to Māori writing about museums and Māori where he considered the current status of the relationship. ${ }^{99}$

Tapsell is another Māori authority who challenges museums and their policies and processes. Tapsell believes that museums must recognize Māori tribal values and not their own processes and ways of operating. Tapsell notes that taonga "were cloaked in the mana, tapu and korero of their origins" 100 and that Māori source communities seek to honour the trajectory of ancestors to whom they belong. ${ }^{101}$

A key theme that has emerged in the area of Māori and museums is the area of consultation and engagement, leading to more active participation in the museums' affairs. ${ }^{102}$ Mere Whaanga reminds us about the significance of relationships when she noted the following with regard to the war canoe Te Toki-a-Tapiri at the Auckland Museum:

Meanwhile, Te Toki a Tapiri resides in an institution devoid of contact with its rightful Kaitiaki - those able to whakapapa to Tapiri who have been appointed to Ngāi Tahu

96 See Hakiwai and Terrell, 1994; Hakiwai, 2005, 2006; Hakiwai, Arapata. 2008. "The Protection of Taonga and Māori Identity in Aotearoa, New Zealand”. In Decolonizing Conservation: Caring for Māori Meeting Houses Outside New Zealand, edited by Dean Sully, 45-58. Walnut Creek, US: Left Coast Press.

97 Hakiwai, 2008, 45.

98 Hakiwai, Arapata. 1994. "Ruatepupuke: Working Together, Understanding One Another”. New Zealand Museums Journal no. 25 (1):44-52.

99 O'Regan, Gerard. 1997. Bicultural Developments in Museums of Aotearoa: What is the current status? Ki te whakamana i te kaupapa Tikanga-a-rua ki roto i Nga Whare Taonga o te Motu: Kei hea e tu ana?

Wellington: Te Papa National Services Te Paerangi, Museums Association of Aotearoa.

100 Tapsell, 2011. 29.

101 Ibid. 96.

102 Gorbey, Ken. 1991. "The Challenge of Creating a Bicultural Museum”. Museum Anthropology no. 15 (4):78.; Gurian, 2005; Hakiwai, 1994, 2005; Henare, 2005; Kawharu, 2002; McCarthy, 2007; Mead, S.M. 1985. "Celebrating New Zealand's Cultural Heritage: A Māori Point of View”. In Interpreting Cultural Diversity, edited by J Hoyle, 16-21. Museum Education Association of New Zealand.; Mead, 1993.; Mead, 1984, 1990, 1993; Simpson, 1996; Sully, Dean. 2007. Decolonising Conservation: Caring for Māori Meeting Houses outside New Zealand. Walnut Creek, California: Left Coast Press Inc; Te Awekotuku, N. and L. Nikora, 2003. Nga Taonga o Te Urewera: A Report prepared for the Waitangi Tribnal's Urewera District Inquiry, August, 2003 (Wai 894, doc B6).; Thomas, Nicholas. 1991. Entangled Objects: Exchange, Material Culture, and Colonialism in the Pacific. Cambridge: Harvard University Press.; Thomas, Nicholas. 1995. Oceanic Art. London: Thames and Hudson.; Thomas, Nicholas. 1999. Possession: Indigenous Art/Colonial Culture. London: Thames \& Hudson Ltd.; Thomas, Nicholas, and Mark Adams. 2009. Rauru: Tene Waitere, Māori carving, Colonial History. Dunedin: Otago University Press. 
Matawhaiti to fulfill that role. However interesting a display may be, it undermines the nature and meaning of taonga if it negates, or even ignores, the relationships that give life to material forms. ${ }^{103}$

Charles Royal's writing on museums and taonga encapsulate key elements of a Māori development framework that is relevant to this research. Royal focuses on the restoration and revitalization of Māori knowledge and culture and asks: what is the contribution of Mātauranga Māori to contemporary Māori culture and the wider society today? For Royal, the contemporary aspirations for the restoration and revitalization of iwi, hapū and whānau cultural knowledge are a critical factor. This revitalization of the culture has to take place in the context of our lives today and it has to occur in a way that is not only internally meaningful to the culture, but it has to hold relevance and responses to issues of our contemporary world. ${ }^{104}$

Museums have become sites of resistance for indigenous peoples who are struggling in their quest for recognition and the assertion of cultural identity. The 'politics of indigeneity' are manifest in many ways and Māori sovereignty or tino rangatiratanga is being asserted to address historic grievances in the Waitangi Tribunal as well as undertaking forward-looking cultural heritage developments. As Butts notes, "Indigeneity is largely about the recognition of a people's mana" and this thesis is all about the recognition of mana Māori motuhake. These expressions of Māori tribal culture and identity have meant that museums remain high in the sights of Māori people.

\section{Culture - Identity - Development}

What the literature on museums and Māori indicates is that Māori taonga are closely connected to the identity of the people and the wider culture and that Māori tribal futures planning also incorporates taonga as an important dimension. Given this interconnectedness, the following section examines the notion of culture, identity and development to further extend the understanding of the nature of taonga.

'Culture' and 'identity' are not easy words and concepts to define, but what is certain is that a people's identity has a direct relationship with culture. The definitions of culture vary, but one definition that is well known and useful for this research is the definition of culture

\footnotetext{
103 Whaanga, 2004. 233.

104 Royal, Charles. 2004. Mātauranga Māori and Museum Practice: A Discussion. Report Prepared by Te Ahukaramu Charles Royal for National Services Te Paerangi. Wellington: National Services Te Paerangi, Museum of New Zealand. 25-26.
} 
provided by UNESCO: "Culture should be regarded as the set of distinctive spiritual, material, intellectual and emotional features of society or a social group, and that it encompasses in addition to art and literature, ways of living together, value systems, traditions and beliefs." 105

Two writers who are particularly important in the literature on culture and identity are Ross Poole and Stuart Hall. Poole believes that culture is not a one-size-fits-all and that every identity carries a conception of its past and its future: "As in memory and anticipation we identify with past and future selves and appropriate their actions as ours, so we make ourselves one with those past and future selves."106 Poole's writing regarding the relationship between culture and identity provides a good platform for this research. Poole believes the importance of culture lies in the notion of identity and that cultural identity defines who you are. If you are confronted with the loss of your identity you will also be confronted with the loss of self: $:^{107}$
A better account of the importance of culture lies in the notion of identity. If my identity is formed within a certain culture, then it defines my fundamental perspective on the world, constitutes me as a member of a community, provides me a set of memories and aspirations, and thus with a past and a future, and it gives me a place which is mine. My cultural identity defines who I am; and when I envisage the loss of that identity, I am confronted with the thought that I will lose my sense of self and cease to be what I am. ${ }^{108}$

Cultures do not remain static and frozen in time for many continue to develop and grow in an age of modernity and globalisation. Arguably, some cultures maintain age-old traditions and customs yet others are quick to adapt and change to meet the challenges and opportunities of the twenty-first century. For the cultural theorist Stuart Hall, culture is a "critical site of social action and intervention, where power relations are both established and potentially unsettled." 109 Hall argues for a specific "positionality' where his theory of cultural identity is derived from both the theory of articulation and the constructionist theory of representation. For Hall "meaning is what gives us a sense of our own identity, of who we are and with

\footnotetext{
105 Winkin, Yves. 2002. “Cultural Diversity: A Pool of Ideas for Implementation”. In UNESCO Universal Declaration on Cultural Diversity, edited by Katerina Stenou, 17-60. Paris, France: United Nations Educational, Scientific and Cultural Organization. 18.

106 Poole, Ross. 1999. Nation and Identity. London \& New York: Routledge.

107 Ibid. 13.

108 Ibid. 119.

109 See Procter, James. 2004. Stuart Hall by James Procter: Routledge.7.
} 
whom we 'belong'- so it is tied up with questions of how culture is used to mark out and maintain identity within and difference between groups."

The anthropologist Friedman believes that the past is always practised in the present, not through imposition but because "subjects in the present fashion the past in the practice of their social identity ... The past that effects the present is a past constructed and/or reproduced in the present." "111 In Friedman's article 'The Past in the Future: History and the Politics of Identity' he argues that identity should take cognizance of historical circumstances and that a global historical perspective was necessary to understand the formation of Greek and Hawaiian identities. ${ }^{112}$ There are multiple factors to consider when looking at identity, but they must be situated within time and space as Friedman notes:

The constitution of identity is an elaborate and deadly serious game of mirrors. It is a complex temporal interaction of multiple practices of identification external and internal to a subject or population. In order to understand the constitutive process it is, thus, necessary to be able to situate the mirrors in space and their movement in time. ${ }^{113}$

The relationship between the past and future with regard to culture and its ongoing development is an important dimension. Appadurai believes we must recognize that the cultural past and cultural future are mutually linked. For Appadurai "Cultural heritage cannot be externally divorced from cultures of aspiration, nor should it be internally divided into tangible and intangible dimensions." $" 114$ This dimension resonates strongly with Māori and how Māori identity is shaped and constructed.

What emerges from the literature on identity is that for me Māori identity and culture share a close relationship with the past, present and future dimensions. This is seen with the tribal case studies presented in this thesis where the future development aspirations position culture at the core with strong connected relationships to their past and, by association, their future

${ }^{110}$ Hall, Stuart. 1997. Representation: Cultural Representations and Signifying Practices. London: Sage in association with The Open University. 3.

${ }^{111}$ Friedman, Jonathan. 1992. "The Past in the Future: History and the Politics of Identity". American Anthropologist no. 94 (4). 853.

112 Ibid. Friedman notes that like Hawaiians, Māori "were not passive dupes of the strange tales of missionaries. They were actively engaged in the construction of bodies of knowledge founded upon their very real social experience and its structures." See Friedman, 1998. "Knowing Oceania or Oceania Knowing: Identifying Actors and Activating Identities in Turbulent times". In Pacific Answers to Western Hegemony: Cultural Practices of Identity Construction, edited by Jurg Wassman. New York: Berg. 54.

${ }^{113}$ Friedman, 1992. 853.

114 Appadurai, Arjun. 2002. "Cultural Diversity: A Conceptual Platform - Sustainable Diversity: The Indivisibilty of Culture and Development". In UNESCO Universal Declaration on Cultural Diversity, edited by Katerina Stenou, 9-15. Paris, France: United Nations Educational, Scientific and Cultural Organization. 11 . 
imaginations. In what is termed 'the capacity to aspire', Appadurai positions culture within a development framework where the people can be full participants in designing their cultural futures. ${ }^{115}$ In adopting Appadurai's views, we clearly see Māori 'culture' as an important dimension for Māori tribal development and that this culture has an enduring relevance, value and connection to both contemporary and future worlds.

UNESCO also recognizes the importance of the relationship between culture and development and notes that "culture is more than a jewel in the crown of development. Because cultural diversity is the engine through which aspiration, heritage and empowerment can be maximized as capacities, culture must also be seen as a motor of development."116 This affirmation of the link between culture and development by UNESCO tells us that culture is an important driver and 'motor' of the development process and, like Appadurai's 'the capacity to aspire', people want to be involved and participate in designing their own cultural futures. This view of the relationship between culture and development is similar with Māori lived experience and reality as Durie reminds us: "Cultures change and develop but in shaping a vision for the future the configuration of the past often provides a framework for reconfiguring that future." 117

The literature on Māori development shows a pattern of continuity since the arrival of the early ancestors from eastern Polynesia. The adaptation and survival to a new and different environment required a development principle based on continuity with the past, but infused with creativity, adaptation and change. ${ }^{118}$ The early period from the hunter-gatherer to early contact has been characterised as being from when "Hawaikian culture became a Māori culture." ${ }^{119}$ Other writers also say that Māori development is happening outside New Zealand in places like Australia and that strategies for new engagements need to be considered. ${ }^{120}$

For Pita Sharples, the former Minister of Māori Affairs, "Māori development spans across generations; across centuries. It promotes social equity and cultural affirmation, while at the

\footnotetext{
115 Ibid. 10.

116 Ibid. 15.

117 Durie, 1998.

118 See Davies, Preston, Ralph Lattimore, and Keith Ikin. 2005. "Māori Economic Development: Overview and Prospects in Economic Development in New Zealand". In Economic Development in New Zealand, edited by James Rowe, 107-26. Aldershot: Ashgate Publishing.; Edwards, William John Werahiko. 2010. Taupaenui Māori Positive Ageing. Doctor of Philosophy, Massey.; Moon, Evan Paul. 2004. The Application of Modernisation Theory to Phases in Māori Development since 1800. MA, Auckland University of Technology.

119 Waitangi Tribunal Wai 262 Report (2011, 15, 33).

120 See Hamer, 2007.
} 
same time inspiring us and stimulating the context of economic self-sufficiency. In other words, it is development according to Māori aspirations." ${ }^{\prime 21}$ For Sharples, Māori development operates in many realms and is evident in many scenarios, including the return of Māori ancestral remains from overseas, cultural tourism, Māori knowledge like star lore, the reclamation of geographical place names and the Māori contribution to World War II. He believes that a sustainable economy is essential to self-determination and that Māori development "promotes social equity and cultural affirmation, while at the same time inspiring us and stimulating the context of economic self-sufficiency."122

A common thread of many writers on Māori development is that this should not be at the expense of what makes us Māori, as noted by Apirana Ngata's famous dictum 'E tipu e rea'. More recently, this was raised at a Post-Settlement Tribal Development conference in 2011 when it was stated: "As iwi businesses grow we must never lose sight of what makes us Māori - Our language, our culture, our heritage. This is the only source of sustainable competitive advantage." 123

Some writers provide models for Māori economic development, but these include improving the circumstances of the people, attaining economic self-sufficiency, and preserving and strengthening the cultural foundations. ${ }^{124}$ Paulin's Māori development framework, for example, incorporates the following.

\section{The means}

Primarily through financial and cultural redress for Treaty of Waitangi grievances, using such compensation to:

Regain control over traditional tribal lands and resources.

Create, operate and invest wisely in businesses that can compete profitably over the long run in the global economy, so as to:

- $\quad$ develop an asset base to ensure long term sustainability

- $\quad$ provide ongoing financial resources for the educational, social and cultural development of Māori.

121 Sharples, Pita. "Manu Ao Academy Seminar - 'Māori Development"”. Wellington: New Zealand Government, 2009.

122 Ibid.

123 Chris Insley was speaking about Ngāti Porou development.

124 Paulin, Charlotte. 2005. "Focus on the Ngāi Tahu Tribe". International Journal of Entrepreneurship and Small Business no. 2 (2):199-207. 
Thus, attaining economic self-sufficiency as a necessary condition to achieve.

The ultimate purposes

Improving the socio-economic circumstances of Māori people

Restoring political equality and respect between Māori and non-Māori

The preservation and strengthening of Māori culture. ${ }^{125}$

Puketapu is another writer on Māori development who believes that there is no universal model of Māori development, but is "best conceptualised as a matrix of variables that are concerned with the translation of Māori ideals into Māori realities." ${ }^{126}$ Other writers stress the inter-generational notion of Māori development and the economy with O'Regan noting the Ngāi Tahu guiding development ethos of 'Mō Tātou, ā, Mo kā uri a muri ake nei'. ${ }^{27}$

\section{Tuakiri Māori - Māori theories of identity}

Māori identity forms an important focus for this research along with its strong relationship with development. What defines and constitutes Māori identity and, more importantly, Māori tribal identity is at the heart of this research thesis. Having a greater understanding of the constructions of Māori tribal identity will provide the foundation on which to see how integral this is to Māori tribal development. In more recent times there have been a number of writers who have interrogated and researched Māori identity and the constructions that make it up.

Speaking at the New Zealand Historical Association Conference in 2007, Durie noted that there was an emerging new dimension to Māori identity that reflected the realities of being youthful in a Māori community and being Māori in an urban situation. This Māori identity was less based on whakapapa, marae and iwi and more on "peer associations, Māori innovation in contemporary music and performance, the use of te reo Māori, adaptation of electronic communication to accommodate Māori language, and a bias towards Māori broadcasting media." "28 Durie's insightful reflections as opposed to the more 'traditional' viewpoint, where identity is still whakapapa-centred in a pastoral and rural environment, are

\footnotetext{
125 Ibid.

126 Puketapu, Brendon. 2000. Māori Organisation and Contemporary Māori Development: Strengthening the conceptual plait. PhD, Māori Studies, Massey, Palmerston North. 315.

127 O’Regan, Tipene. 1994. “The Ngāi Tahu Claim”. In Waitangi: Mãori and Pakeha Perspectives of the Treaty of Waitangi, edited by I. H. Kawharu, 234-262. Auckland: Oxford University Press.

128 Durie, Mason. 2011. Ngā Tini Whetū: Navigating Māori Futures. Wellington: Huia Publishers.
} 
important as we consider Māori tribal identity in modern contemporary times and the role that taonga play with respect to Māori tribal identity and development.

My thinking and writing aligns with Durie's philosophies, models and frameworks as they address directly the areas of Māori identity, Māori health, Māori development and Māori cultural heritage. Durie has published extensively in the area of Māori health and, in no significant measure, he has also contributed significantly to the literature on Māori selfdetermination and development. ${ }^{129}$ The two models developed by Durie and of relevance to this research are the Whare Tapa Wha and Te Pae Mahutonga models. These matrix models are holistic, inter-related and underpinned with Māori concepts and principles drawn from Māori experience and cultural world views.

The Whare Tapa Wha model is based on 'a four-sided concept representing four basic tenets of life. ${ }^{130}$ The model represents the four corners of a house and represents the taha wairua (spiritual dimension), taha tinana (physical wellbeing), taha hinengaro (mental wellbeing) and taha whānau (family wellbeing) dimensions. Durie's Whare Tapa Wha model is a relevant model, having been used as a framework for a range of services in different sectors, including policy, health, mental health, public health education, justice and kaupapa Māori health services. ${ }^{131}$ The adoption of the whare as a conceptual device to explain what constitutes Māori identity shows the power of taonga deep in Māori thinking. This also applies to how many tribes have referenced key philosophies, visions and strategies in taonga-related terms, such as the tōpuni tauwhainga or chiefly cloak title to describe the Ngāti Kahungunu Cultural Standards Project or the words 'Pinepine te Kura' taken from the well-known waiata oriori of Ngāti Kahungunu for the tribal philosophy of Ngāti Kahungunu.

The Te Pae Mahutonga model is named after the Southern Cross star constellation and includes the dimensions of: Mauriora - Access to te ao Māori; Waiora - Environmental Protection; Toiora - Healthy Lifestyle; and Te Oranga - Participation in Society. Durie's Te Pae Mahutonga model is used as a symbolic map for bringing together the significant components of health and culture in an integrated, relevant and meaningful way. An

${ }^{129}$ Durie, Mason. 1994. Waiora Mana-a-Iwi: Māori Development and Health Reforms. Auckland: Oxford University Press.; Durie, Mason. 1999. "Te Pae Mahutonga: A Model for Māori Health”. Health Promotion Forum of New Zealand Newsletter, no. 49:2-5.

${ }^{130}$ Durie, 1994; Durie, Mason. 1998. "The Treaty Was Always About the Future". In Living Relationships: Kokiri Ngātahi, edited by Ken S Coates and P G McHugh, 189-193. Wellington: Victoria University Press.

131 Cherrington, L. and Bridget Masters. 2005. Literature review of Māori models of health and indigenous injury prevention and health promotion interventions. Prepared for Ronald Karaitiana, Cultural Strategies Manager, Injury Prevention, Accident Compensation Corporation, Lower Hutt. 7. 
important part of this model with respect to the Mauriora dimension is that it rests on a 'secure' Māori cultural identity, which includes access to language and knowledge; access to culture and cultural institutions, such as marae; access to Māori economic resources, such as land, forests and fisheries; and access to social resources, such as whānau.

Jhanke's research on six Māori women educators revealed the importance of the 'homeplace' to a secure Māori identity. This was reinforced through physical links to the land, knowledge of genealogy, the importance of the marae and experience of the Māori language.

As Jhanke says:

The study revealed that the centrality of the identity of each of the women, and their specific historical and cultural realities are grounded in tribal genealogy and in the customary traditions and values of their ancestors." 132 She further adds: "These characteristics, important markers of personal identity, emerged as significant for each of the women in this study and as such demonstrated a secure identity as Māori. ${ }^{133}$

Durie says that a necessary prerequisite for good health, wellbeing and cultural identity depends not only on access to culture and heritage "but also on the opportunity for cultural expression and cultural endorsement within society's institutions ... too many are unable to have meaningful contact with their own language, customs, or inheritance." 134 The Te Hoe Nuku Roa research project tracks seven hundred representative Māori households over a tenyear period and will be an important indicator that measures Māori aspirations, achievements, concerns and levels of participation in Māori society. ${ }^{135}$ This research project will be vitally important in providing quantitative and qualitative information on Māori identity and Māori wellbeing.

Rawinia Higgins' research on five Tūhoe women with moko kauae also remind us that Māori art forms like the moko kauae are not only a means of expressing Māori identity and selfdetermination but also a powerful way to express Tūhoe identity or Tūhoetanga. Higgins shows that there is a link between their moko kauae and their Tūhoe identity and that their decision to get the chin moko was in large part derived from their sense of their Tūhoe

\footnotetext{
132 Jahnke, Huia. 2002. "Towards a secure Māori identity: Māori women and the home-place". Women's Studies International Forum no. 25 (5):503-513.

133 Ibid. 511.

134 Durie, 2003, 68.

135 Ibid. 69.
} 
identity: "Tūhoetanga provided the basis of their decision to acquire moko kauae because it relates to the identity politics of the past, as a symbol for the future."136

Higgins believes that there are other layers of Māori identity that are expressed in concepts such as whanaungatanga, manaaki and aroha: "These elements are not only important as expressions of identity towards a specific iwi but also of how the individual perceives their position amongst their kin." ${ }^{\prime 137}$ As an extension of these concepts, Higgins notes the wharenui or meeting house model as a way of understanding the different elements and relationships with respect to Māori identity. ${ }^{138}$

The wharenui model draws from these concepts along with whakapapa, tipuna, whenua and atua. The symbol of the wharenui as a model for identity includes the many tribal tipuna or ancestors as depicted by the poupou when you enter the house. These tipuna connect the past with the present while the other parts of the whare, such as the heke or rafters, represent layers of whakapapa from the gods to individual ancestors. For many, these provide a strong sense of belonging and a strong sense of collective and individual identity. As Higgins says: "Sitting or sleeping at the base of these ancestors forms the continuation of the whakapapa." 139

Māori identity is also expressed in other Māori concepts such as mana - mana atua, mana whenua and mana tangata. Higgins outlines the Māori identity model titled 'He Tihi Tangata - Māori Collective Identity' as a model that shows the relationships of customary concepts important to identity. This model is based on the niho taniwha tukutuku pattern as being representative of the mana of the people. The tukutuku patterns are used to represent the chiefs and their communities, while the triangular patterns suggest mountains that show the relationships between people and the land. The three forms of mana adopted within the triangular diagram are mana atua (whakapapa, tipuna), mana whenua and mana tangata (whanaungatanga, aroha, manaaki). ${ }^{140}$

\footnotetext{
${ }^{136}$ Higgins, Rawinia. R. 2004. He Tānga Ngutu, He Tūhoetanga. Te Mana Motuhake o te Tā Moko Wāhine: The Identity Politics of Moko Kauae. PhD, Te Tumu - School of Māori, Pacific and Indigenous Studies, University of Otago, Otago. 234.

${ }^{137}$ Ibid. 330 .

${ }^{138}$ Ibid. 333. The wharenui model diagram is referenced to Higgins and Moorfield (2003: 75). The Waitangi Tribunal 262 Report (2011) noted that the whare tupuna was more than just a gathering place for the community. "It was also a record of its history and whakapapa, a reflection of its environment, and it epitomized the idea that the living and the dead exist in the same space and time." (p.35).

139 Ibid. 333.

${ }^{140}$ Ibid 336-338.
} 
Māori tribal identity is shaped by its own unique histories and circumstances. How the tribes see, experience and know the world to be is an important dimension of both their tribal identity and culture. This ontology extends to include mātauranga Māori and kaupapa Māori research methodology, which takes as its core the legitimacy and validity of Māori indigenous knowledge systems, customs, tikanga, values and worldviews. The late John Rangihau commented on Māori tribal identity and Māoritanga and his words have become classic statements during the 1960s and 1970s renaissance period. For Rangihau, his tribal Tūhoetanga was more important than that of being a Māori or embracing that of Māoritanga. This iwi-centric contextual view of Māori tribal identity operated more in the 1990s.

My being Māori is absolutely dependent on my history as a Tuhoe person as against being a Māori person. It seems to me there is no such thing as Māoritanga because Māoritanga is an all-inclusive term, which embraces all Māori. And there are so many different aspects about every tribal person. Each tribe has its own history. And it's not a history that can be shared among others. How can I share with the history of Ngāti Porou, of Te Arawa, or of Waikato? Because I am not of those people. I am a Tuhoe person and all I can share in is Tuhoe history. ${ }^{141}$

This view of Ngāi Tūhoe tribal identity, as well as a more general pan-Māori identity, is expressed by others. Te Wharehuia Milroy, for example, says: "I am first and foremost Tūhoe, secondly I am a Māori, and thirdly I am a Pakeha." ${ }^{142}$ In recognizing Sid Mead's writing that 'Māoritanga recognizes the past as a means for functioning in the present' ${ }^{143}$, Higgins highlights this relationship between past and present:

Māori identity is viewed from the position that an individual stands on a time continuum alongside their ancestors and their future descendants. This determines the strong relationship between the existence and lives of the ancestors and the shaping of the identity of the individual today. ${ }^{144}$

For some commentators there are issues about establishing a 'secure' Māori identity based solely on particular indicators like te reo Māori, tikanga and knowledge of marae and

\footnotetext{
141 Rangihau, John. 1992. "Being Māori”. In Te Ao Hurihuri-Aspects of Māoritanga, edited by Michael King, 185-190. Auckland: Reed Books. Higgins says that Māoritanga is viewed as not only maintaining a sense of identity in Aotearoa, New Zealand, but it is also used by Māori as a response to the continual domination of Pakeha culture. (Cited in Higgins, 2004. 326).

${ }^{142}$ Milroy, W. 2008. "Indicators of Tribal Identity in Aotearoa/New Zealand." Te Kaharoa 1. 185.

143 See Mead, Hirini Moko. 2012. "Understanding Mātauranga Māori and Global Indigenous Knowledge." In Conversations On Mātauranga Māori, edited by Haemata Ltd, T. Black, D Bean, W. Collins and W. Nuku, 9-14. Wellington: New Zealand Qualifications Authority.

${ }^{144}$ Higgins, 2004. 326.
} 
whakapapa, as often this is seen as problematic for those who do not fit these criteria. ${ }^{145}$ McIntosh believes that Māori identities are complex and that a fluid Māori identity can be seen as part and parcel of the dynamics of identity formation. Here identity borrows and transforms many of the so-called 'fixed' elements found in what is regarded as a traditional Māori identity. McIntosh notes that, over time, it is likely that many of these fixed elements of this identity will be seen as part of an established Māori identity. ${ }^{146}$ Jones supports this notion and believes Māori identity faces new challenges akin to those encountered in urban areas of the United Kingdom and the United States:

Social change has altered the character of Māori identity and now poses questions that are more akin to those of inner urban areas in the United Kingdom or the United States, than those associated with traditional societies reeling from the impact of outside culture. $^{147}$

The importance of connection, identity and place strongly feature in Māori identity formation. ${ }^{148}$ Te Awekotuku and Nikora speak about the importance of connection, identity and place as enmeshed in the Tūhoe concept of matemateaone in their report 'Nga Taonga o Te Urewera' for the Ngāi Tūhoe Waitangi Tribunal claim hearing. Te Awekotuku writes: "People make places just as much as places make people. People and places derive their identities from each other to a significant extent. It is the betweenness that is important - the relationship that is created and sustained."

Matemateaone as Te Awekotuku says is about context and "a living philosophy practiced by a living dynamic community, in which the values sustain the people who continue the values." ${ }^{150}$ A definition of matemateaone is given by Wharehuia Milroy:

As we understand it, it is a dynamic associated with the manner in which we Tuhoe organise ourselves socially, culturally, politically and spiritually. They are our ideals as an iwi, moral dictates that say how we are to behave. Matemateaone grows from within

${ }^{145}$ Borrell, Belinda. 2005. "Living in the City Ain't so Bad: Cultural Identity for Young Māori in South Auckland". In New Zealand Identities: Departures and Destinations, edited by James Liu, Tim McCreanor, Tracey McIntosh and Teresia Teaiwa, 191-206. Wellington: Victoria University Press.

${ }^{146}$ McIntosh, Tracey. 2005. "Māori identities: Fixed, fluid, forced". In New Zealand Identities: Departures and Destinations, edited by J Liu, T McCreanor, T McIntosh and T Teaiwa, 38-51. Wellington: Victoria University Press.

147 Jones, Shane. 2006. "Development and Māori society: building from the centre or the edge?". In Culture and Sustainable Development in the Pacific, edited by Antony Hooper, 159-173. Canberra, Australia: Asia Pacific Press.

${ }^{148}$ For Jhanke (2002) the ancestral home-place was a vital dimension of a secure Māori identity for six Māori women educators. The sense of home-place and connections, whether physical or metaphysical, were an important part of the reality and what it means to be Māori for the six women. (p.506).

${ }^{149}$ Te Awekotuku, 2003. 11.

${ }^{150}$ Ibid. 22. 
the group, knowing and getting to know each other. The physical cues such as trees, mountains, rivers and kainga etc. are all factors that activate matemateaone. Everyone of Tuhoe should share a subtle code of knowledge that goes to make up matemateaone. ${ }^{151}$

In describing Ngāi Tūhoe tribal identity, Te Awekotuku says: "Matemateaone has many definitions, but each one has a persistent theme - nurturing relationships between people and with the environment which nurtured them." of place and locality to Māori tribal identity and, in particular, Tūhoe identity. The intimate enduring relationship with Te Urewera and the whenua is identity-laden as "people strive for a sense of belonging to a place. This sense of belonging arises from the operation of three psychological processes: familiarity, attachment and identity." 153 Te Awekotuku says that Te Urewera act as psychic anchors that remind the people where they come from and "provide a lifeline to a continuous sense of identity."154

Doherty adopts a similar view and reaffirms the connection between the people and the tribal landscape of Te Urewera.

Te Urewera is the territory that Tūhoe occupies and through whakapapa Tūhoe genealogically connects to Te Urewera. Te Urewera is the land base that builds the identity for Tūhoe. It is the interaction Tūhoe has with its land base that established Tūhoe as a distinct grouping of people, different from other tribes. It is the connection to the land base that provides the platform for Tūhoe to build its identity; this is the tūrangawaewae (place of standing), this is the Tūhoe comfort zone. ${ }^{155}$

The relationship between connection, place and identity is further emphasized by other writers. Pishief, for example, in her heritage studies research on 'constructing the identities of place' came to the conclusion that it was the 'connect' that was important: "The connect is an intangible entity floating over the physical/material world between places and people that emerges through the physical presence of people at places."156

Carter also reminds us that there are powerful symbols of Māori tribal identity and that symbols unite place with location to express identity. In adopting the words expressed at a

151 Cited in Te Awekotuku, 2003. 23.

152 Ibid. 21

153 Ibid. 71.

154 Ibid. 16.

155 Doherty, Wiremu. 2012. "He Rarangi Kaupapa". In Conversations on Matauranga Māori, edited by Haemata Ltd, Taiarahia Black, Daryn Bean, Waireka Collings and Whitney Nuku, 15-36. NZQA. 27.

156 Pishief, Elizabeth Dale. 2012. Constructing the Identities of Place: An Exploration of Mãori and Archaeological Heritage Practices in Aotearoa, New Zealand. PhD, Museum Studies, Victoria University, Wellington. Pishief's 'connect' is similar to Te Awekotuku's notion of 'the betweeness'. (See Te Awekotuku 2003.) 
Waitangi Tribunal Claim hearing on the northern tribes, Carter expresses the importance of place, space and whakapapa to identity:

The physical presence recalls the name. The name recalls the event. The event recalls the whakapapa. The whakapapa recalls the connections between things past and things present. The connections between things past and things present is the element which gives... pride and identity. ${ }^{157}$

Although the connection to place and locality are important Māori tribal identity markers, there are nonetheless significant identity-making constructions taking place away from the home region or tūrangawaewae. This is illustrated by Hooper-Greenhill with respect to Ngāti Ranana and the meeting house Hinemihi in Clandon Park in England. ${ }^{158}$ Hooper-Greenhill mentions the repetition of performative acts as a way that cultural identity can be established and reinforced and that Māori treasures are kept alive and their histories reactivated by being touched, wept and talked over, and by taking part in gatherings and ceremonies. ${ }^{159}$ HooperGreenhill reminds us that Māori are able to fully participate in today's world by wearing two hats; one that is European and western, the other that is the 'Māoriness'. This has similarities to what Salmond refers to as the 'ethnography of occasions'. ${ }^{160}$

\section{Conclusion}

The literature review examined key bodies of knowledge and particular themes and concepts emerged, such as culture as generative, the importance of revitalization, regeneration and renewal of cultural identity, the liberation from the legacy of colonization, and the deep knowledge and understanding that Māori have for their taonga. It is clear that material culture and taonga are important for source communities, both in historic terms and for the present and future.

Liberating museums from what is often described as outdated and stifling traditional museum practice into something that has relevance and meaning to its publics and source communities has been expressed by many writers. ${ }^{161}$ These writers are actively engaging in the politics of

\footnotetext{
157 Carter, 2010.

${ }^{158}$ Hinemihi (Hinemihi o te Ao Tawhito) currently resides in Clandon Park, Surrey, England and was purchased from Ngāti Hinemihi in 1892 by William Hillier, the 4th Earl of Onslow and Governor of New Zealand (1888-1892). For a more detailed account of Hinemihi, see Sully, 2007.

159 Hooper-Greenhill, Eilean. 1998. "Perspectives on Hinemihi - a Māori meeting house". In Colonialism and the Object, edited by Tim Barringer and Tom Flynn, 129-143. London and New York: Routledge.

160 Salmond, 1983. 211.

161 Ames, 1989, 1992; Clavir, 2002; Clifford, 1997; Conaty, 1989; Galla, Amareswar. 1996. "Indigenous Peoples, Museums and Frameworks for Effective Change". Curatorship: Indigenous Perspectives in Post-
} 
indigenous recognition and advocate for stronger involvement with indigenous peoples over and above the relationships established in exhibitions and collaborative research projects. The contemporary role of museums to recognize the vitality of living cultures and to be a platform for their future development and revitalization is a key driver for many indigenous peoples. ${ }^{162}$

The literature review revealed a multi-dimensional matrix to Māori identity that was underpinned with key characteristics, including the importance of whakapapa, place and location, language and tribal traditions, and the relationships with ancestors and histories. The changing demographics, urban drift and resettlement in places like Australia have also meant the creation of new strategies to maintain tribal identity and one's sense of belonging. ${ }^{163}$ Durie's notion of a 'secure Māori identity' with access to cultural knowledge and resources is affirmed in the literature.

\section{Theoretical framework}

The literature review has highlighted a significant gap in the writing on museums and indigenous people on the one hand, and development on the other. This thesis seeks to understand these subject areas better with regard to Māori and their relationship to their cultural heritage or taonga. The review has also highlighted the growing literature on museums and their relationships with source communities, including indigenous and First Nation peoples. My theoretical framework employs developmental and futures concepts in an examination of tribal taonga and their 'connectedness' to the wider culture. Māori theories and concepts are also employed in the research to reveal how taonga are connected to the Māori world and how this connectedness is manifested in tribal strategies of development.

This framework aligns well with Appadurai where he says that the cultural past and cultural future are mutually linked and positions culture within a development framework where the people can be full participants in designing their own future. For Appadurai, heritage cannot be divorced from cultures of aspiration, ${ }^{164}$ like that of Māori. Also important is Kreps' postcolonial critique where she cites Galla's 'cross cultural heritage management' that recognizes

Colonial Societies no. 8:82-95.; Healy and Witcomb, 2006; Karp and Levine, 1991; McLoughlin, M. 1999. Museums and the Representation of Native Canadians and First Nations. Vancouver: University of British Columbia Press.; Knell, Macleod and Watson, 2007; Simpson, 1996; Stanley, 2007.

162 Abungu, 2006; Battiste, 2000; Hill, 2001; Stanley, 2007; West, 2004, 2005.

163 See Hamer, Paul. 2007. Mãori in Australia: Nga Māori i te ao Moemoea. Edited by Te Puni Kokiri. Wellington: Te Puni Kokiri.

164 See Appadurai, 2002. 
diverse concepts and approaches to management and that "Cross-cultural heritage management strategies do not simply entail the mixing or merging of concepts and approaches. Rather, they acknowledge the right of each to be understood and respected on their own terms while coalescing around unified goals." 165 This positioning is fundamental to kaupapa Māori research discourse where Māori taonga are understood in their own terms and within their own value systems. My framework supports the view that the contemporary role of museums is to recognize the vitality of living cultures and to be a platform for their future development and revitalization of indigenous peoples. ${ }^{166}$

My research framework adopts a post-colonial thinking and imagining, advocating for a holistic understanding of a healthy and secure Māori tribal identity. In this respect the relationship between Māori identity and cultural heritage will be viewed within a broader frame of Māori economic, social and cultural development. Adopting a developmental approach with Māori identity in relationship to Māori taonga creates a heritage futures approach that aligns well with Durie's writing when he says: "Cultures change and develop but in shaping a vision for the future the configuration of the past often provides a framework for reconfiguring that future." 167 This is also consistent with Sissons when he says: "Indigenous reappropriations represent futures redirected". 168

Reclaiming and revitalizing indigenous heritage and knowledge is seen as a vital part of decolonization, as is the pursuit of self-determination. Important for my research is what Kreps describes as championing the growing importance of culture-based approaches to community development and the role museums play in this culture as a foundation for development. ${ }^{169}$ As mentioned earlier, this is important for my research, as Māori tribes are increasingly seeing museums as potential places to aid and assist Māori tribal development.

This thesis is not about museum practice per se, but rather about making a contribution to the museum studies discourse by expanding museum studies, cultural studies and development studies with respect to the development dimensions of a 'living'contemporary Māori culture. The shift from heritage as evidence of the past to recognition of the contemporary value of

\footnotetext{
165 Kreps, Christina. 2007. "The Theoretical Future of Indigenous Museums: Concept and Practice". In The Future of Indigenous Museums: Perspectives from the Southwest Pacific, edited by Nick Stanley, 223-234. New York \& Oxford: Berghahn Books. Kreps mentions the 'traditional care'of Native Americans as practices that have been adopted by mainstream anthropology and natural history museums.

166 Abungu, 2006; Battiste, 2000; Hill, 2001; Stanley, 2007; West, 2004, 2005.

167 Durie, 1998. 79.

168 Sissons, Jeffrey. 2005. First Peoples Indigenous Cultures and their Futures. London: Reaktion.

169 Kreps, 2003. 10.
} 
heritage for living cultures is inherent in Moira Simpson's writing along with the broader

aims to restore, rejuvenate and revitalize contemporary cultural identities and processes. ${ }^{170}$ Reclaiming and revitalizing indigenous heritage and knowledge is seen as a vital part of decolonization.

In conclusion, the theoretical framework adopts a development paradigm that supports the writing of Simpson, Kreps, Paulin and Durie where the framework looks at the past in helping to shape visions for Māori tribal futures. Ensuring long-term sustainability in economic, social and cultural terms includes the strengthening of Māori culture and the connectedness of taonga with regard to Māori tribal identity and development. The nature of Māori taonga with their own customary cultural values and characteristics is an important dimension of the framework, along with their wider holistic relationships to the Māori world in the past, present and future.

\section{Research design}

The literature review section surveyed the writings of key authors associated with my field of study. The methodology that I employed evolved and changed as I gained new knowledge and understanding. What was apparent from the beginning was that what were needed were 'insider' tribal perspectives on tribal identity and development and the role of tribal taonga within that. My working experience over the last 20 years provided me with an opportunity for a self-reflexive ethnography based on my interactions with iwi on a range of kaupapa.

Originally, my research was based on and around key framing questions that explored and examined the relationship between Māori identity and development through the agency of taonga. The primary research question at that time concerned how taonga in museums are related to Māori identity and development. The secondary research questions included: What is Māori identity and how is this manifested? What part do taonga in museums play in Māori development? What is the role of museums in recognizing the contemporary value of heritage for living cultures? And how and why are New Zealand museums today reconnecting taonga to descendent source communities?

These questions, however, morphed and changed as I interviewed tribal members, examined tribal websites, visions and planning documents, and perused a range of literature on Māori tribes. My research question also changed as the multi-dimensional nature of Māori tribal

${ }^{170}$ Simpson, 2009. 
identity became apparent, as did the nature of Māori tribal development. Keyword searches were made on library databases and web pages along with publications and unpublished materials.

My theoretical research framework aligns with the models proposed by Professor Mason Durie, Robert Jhanke and Graham Hingangaroa Smith with respect to cultural relevance and meaning. ${ }^{171}$ These writers provide strong Māori models based on Māori language, values, customs and principles. They also draw their frameworks based on Māori experiences of the past and the reshaping of these for self-determining cultural futures and development. The models and epistemologies draw on concepts and principles that are consistent with Māori worldviews.

The research design that I have adopted is informed through working for a number of years in the museum sector and an active involvement in my tribal affairs. An essential element of the theoretical framework was therefore self-reflexive, as well as drawing on disciplines, including anthropology, Māori studies, cultural studies and museum studies. The theoretical models associated with Māori identity and development were particularly pertinent and my research in this area has been influenced by writers, such as Durie, Mead, Tapsell and Te Awekotuku, as well as the interface between indigenous people and museum practice with the likes of Kreps, Simpson and Watson.

The case studies focus primarily on two major tribes that have undertaken tribal art and cultural projects in more recent times: Ngāi Tahu of Te Waipounamu in the South Island, and Ngāti Kahungunu of the East Coast of the North Island. Other tribes and tribal art and taongarelated projects will be assessed to test the research propositions.

The research methodology draws upon a range of disciplines and theoretical frameworks, including critical theory, self-ethnography and kaupapa Māori. Having a Māori-centred approach for this research ensures that it remains relevant to Māori and has meaning and value in Māori terms. Mason Durie's Te Pae Mahutonga model is a model that is used for health promotion and will be used in this research as a key theoretical framework. Other principles from humanities disciplines have been adopted, including Joe Te Rito's whakapapa

171 See Durie, M. 2002. The CHI Model: A Culturally Appropriate Auditing Model. Wellington, Public Health Commission.; Durie, 1998, 2009; Jahnke, Robert. 2006. He Tataitanga Ahua Toi: The House that Riwai built/a continuum of Māori Art. PhD, Māori Studies, Massey University, Palmerston North.; Smith, 1999. 
paradigm for understanding Māori identity and Moira Simpson's resocialization of objects as a way to restore taonga of cultural and spiritual heritage to their living cultures. ${ }^{172}$

Decolonizing research methodologies have been created thanks to writers like Linda Smith who has created invaluable insights on which to reflect, examine, critique and challenge socalled right ways of doing things. ${ }^{173}$ Indigenous scholars are advocating for the recognition of indigenous rights and the right for self-determination. The post-colonial discourse and the politics of indigeneity by indigenous scholars have provided the museum 'sector' with a much-needed wake-up call regarding responsibilities and obligations of cultural treasures and knowledge. Looking at Māori ways of being and Māori ways of knowing provides meaningful solutions and benefits. As Smith writes: "Decolonization is about centering our concerns and worldviews and then coming to know and understand theory and research from our own perspective and for our own purposes."174

This is a thesis in museum studies, although its trajectory moves through and across related disciplines including anthropology, development studies, cultural studies, indigenous studies, Māori studies and Kaupapa Māori and Mātauranga Māori. Given that the research has Māori at the centre, my thesis advocates for a Māori-oriented framework and paradigm that ensures relevance, meaning and value. This framework is grounded in Kaupapa Māori, which is a discourse and critical theory based directly on Māori lived realities and experiences. Kaupapa Māori challenges the political context of unequal power relations and associated structures. Kaupapa Māori challenges the Pākehā (European) worldview in research where the dominant paradigm has exerted control over process and decision-making. ${ }^{175}$ A leading authority on Kaupapa Māori research theory, Russell Bishop, points out that this research discourse is located within an alternative worldview and that this emerged from within the revitalization of Māori communities in the 1950 to 1980s that saw a rise in political consciousness among Māori that promoted Māori revitalization and cultural aspiration. ${ }^{176}$

172 See Te Rito, J. 2007. "Whakapapa: A Framework for Understanding Identity". MAI Review no. 3:1-8; Simpson, 2009.

173 Smith, 1999.

174 Ibid. 39.

175 Bishop, Russell. 1994. "Initiating Empowering Research?”. New Zealand Council for Educational Research no. 29 (1):175-188.

176 See Bishop, 1994; Bishop, Russell. 2008. “Te Kotahitanga: Kaupapa Māori in Mainstream Classrooms”. In Handbook of Critical Indigenous Methodologies, edited by Norman K. Denzin, Yvonna S. Lincoln and Linda Tuhiwai Smith, 439-458. Los Angeles, London, New Delhi, Singapore: Sage. Bishop believes that the "control exercised by the dominant Pakeha research community needs to be challenged in order that the power of research can be unleashed for the betterment of Māori people." (Bishop, 1994, 186). 
By nature it asserts the validity and legitimacy of Māori knowledge, language, custom and practice. Kaupapa Māori is an ontological research discipline that privileges Māori knowledge, world views, customs and values. This framework follows that of Bob Jhanke's thesis in his examination of Māori visual art from a Kaupapa Māori perspective. ${ }^{177}$ Jhanke's use of tataitanga reo, tataitanga korero and tataitanga kaupapa toi offers an effective model on which to ground art in an art paradigm of Māori cultural relativity and relevance.

Jhanke asserts that: "Tataitanga ahua is an ideological statement about the necessity to contextualise the art within the culture in order to make it culturally relevant to Māori." ${ }^{178}$ As Jhanke points out: "At an ideological level, a tataitanga reo method implicates visual culture within a cultural continuum of Māori language revitalization and the survival of Māori as a people within the context of mātauranga Māori as a valid dimension of Māori research." ${ }^{\prime 19}$ In this way, my research represents a commitment to the restoration and construction of a knowledge and understanding that conforms to Māori indigenous concepts and values. Māori taonga must be understood on their own terms and within the cultural value system from which they originate.

Kaupapa Māori theory is one such discourse that is highly relevant for my research as it is culturally relevant and meaningful for the source culture in question. Bishop says that the concept of rangatiratanga is fundamental to Kaupapa Māori and that self-determination means the right to determine one's own identity and to "define and pursue a means of attaining that destiny in relation to the others." Linda Smith, another leading authority on Kaupapa Māori research methodology, expressed it in this way: "We have a different epistemological tradition that frames the way we see the world, the way we organize ourselves in it, the questions we ask, and the solutions we seek." ${ }^{180}$ In recognizing the Treaty of Waitangi as a document that affirmed Māori rights, the Māori lawyer Moana Jackson had this to say in relation to research: "We have to accept that the Treaty did not submit use to the

\footnotetext{
177 See Jahnke, Robert, 2006.

178 Ibid. 32.

179 Ibid. 30

180 Smith, Linda Tuhiwai. 2000. "Kaupapa Māori research”. In Reclaiming Indigenous voice and vision, edited by M Battiste, 225-247. Canada: UBC Press.
} 
research methodologies and ethics of somebody else. The Treaty affirmed our right to develop the process of research which are appropriate for our people."181

Kaupapa Māori research theory and practice notes three areas that take for granted a Māori ontology and epistemology as identified by the architect of Kaupapa Māori, Graham Smith: ${ }^{182}$

- $\quad$ The validity and legitimacy of Māori are taken for granted

- The survival of Māori Language and culture is imperative

- The struggle for autonomy over our own cultural wellbeing and over our own lives is vital to Māori struggles

Kaupapa Māori research methodology has been used successfully in a range of environments and projects, and continues to provide a culturally appropriate way to carry out research with Māori communities. This research adopts a Kaupapa Māori framework to ensure that Māori ways of knowing and being are identified, along with understandings of taonga and tribal development from within the culture. In this respect, the relationship between Māori identity and cultural heritage will be viewed within a broader frame of Māori economic, social and cultural development.

Adopting a developmental approach with Māori identity in relationship to Māori taonga creates a heritage futures approach, an imagining which will fill a gap in this area of research and ultimately contribute to Māori tribal development through the museum sector. The thesis structure explores the politics of Māori tribal identity and Māori tribal development through a detailed examination of existing literature coupled with tribal development initiatives.

Personal interviews with tribal leaders have provided invaluable insights into the thinking and operations of Māori tribal development and tribal identity formation.

Some key questions that have helped guide and inform my doctoral research include:

- What is Māori tribal identity and how is this manifested?

- What is Māori tribal development?

181 Cram, Fiona, and Vivienne Kennedy. 2010. "Researching with Whānau Collectives". MAI Review no. 3:5. (Original reference is Moana Jackson as the keynote speaker at the Hongoeka Declaration of Māori health in 1996, p.18.)

182 See Smith, Graham Hingangaroa. 1997. The Development of Kaupapa Māori: Theory and Praxis. $\mathrm{PhD}$, Education, University of Auckland, Auckland. 
- What is the nature of Māori tribal taonga and how are they being used to express Māori tribal identity and to enhance tribal development strategies?

- Do taonga have a role to play with regard to Māori tribal identity and development?

\section{Methodology}

This research thesis adopted a case study approach with specific iwi and hapū cultural initiatives to identify key relationships associated with Māori identity and development elements. The primary data for this research was gathered using the methods of personal interviews with key informants and targeted case studies of Māori and museum project relationships, Māori exhibitions and Māori tribal development initiatives. Qualitative interviews were undertaken with people identified during initial scoping, along with the observation of museums, museums and source communities, museums and Māori and Māori tribal self-determination initiatives. Māori responses to my dissertation question were critical to the argument developed in this thesis.

My research methodology was inclusive and reflexive and based largely on interviewing key people and collating pertinent information relating to the tribal taonga case studies. The methodology used for the doctoral dissertation is a combination of critical theory, Kaupapa Māori and self-ethnography, although other disciplines were adopted where relevant. My personal involvement in many art and taonga-related projects over the years provided a depth of reflection and observation. This self-ethnography approach was largely based on participant observation, which Wisker says is: "a rich source of information for the researcher. It enables you to capture what people actually do rather than what they say they do. You can observe them in context and relate to your research questions while you observe." 183

The following methods to gather data for this research topic were adopted.

1. Qualitative interviews - one on one, kanohi ki te kanohi approach

2. Case studies

183 Wisker, Gina. 2008. The Postgraduate Research Handbook. New York: Palgrave Macmillan. Reprint, 2 nd. 203. 


\section{Qualitative interviews}

The research draws on the involvement and personal experience of many contributors within Māori tribal organisations and museums, as well as selected artists, where appropriate.

Qualitative one-on-one interviews or kanohi ki te kanohi with key iwi tribal members were undertaken to provide first-hand accounts and experiences from 'insider' tribal perspectives. This information formed the body of my primary research material. The interviews were semi-structured with specific questions being asked, but this was opened up to allow a freeflowing of ideas from the interviewee. The unstructured interviews were modelled on a conversation and had their own set of interactional rules, given the association with the interviewees. ${ }^{184}$ The interviews focused around Māori tribal identity, taonga and tribal development initiatives focusing on visions and known case studies of iwi taonga reconnection, including specific exhibitions and taonga cultural projects associated with that particular tribe.

The interviews were transcribed and a matrix of common themes was established. These interviews formed an important foundation for eliciting iwi responses regarding their relationship to Māori taonga and Māori identity within their own tribal development strategies. The interviewees included Māori tribal members young and old, male and female, leaders and workers. I also used comments made by the interviewees printed in published material to supplement the primary research material. The people I interviewed included Māori tribal members, artists and academics who were either directly or indirectly involved in the case studies of this research. The interviewees were:

- $\quad$ Mark Solomon, Kaiwhakahaere of Te Rūnanga o Ngāi Tahu

- Sir Tipene O'Regan, former Chairman of the Ngāi Tahu Trust Board and architect of Ngāi Tahu's Waitangi Tribunal Claim

- $\quad$ Puamiria Parata-Goodall, project leader for Te Rūnanga o Ngāi Tahu and heavily involved in the Mō Tâtou Ngāi Tahu Exhibition; Puamiria formerly worked for the Canterbury Museum

- $\quad$ Professor Piri Sciascia, Māori Pro-Vice Chancellor of Victoria University and member of the Mō Tātou Ngāi Tahu Exhibition Working Group

\footnotetext{
${ }^{184}$ See Holland, J., and C. Ramazanoglu. 1994. "Coming to Conclusions: Power and Interpretation in Researching Young Women's Sexuality”. In Researching Women's Lives from a Feminest Perspective, edited by M. Maynard and J. Purvis, 125-48. London: Taylor \& Francis.
} 
- $\quad$ Megan Tamati-Quennell, Concept Developer of the Mō Tātou Ngāi Tahu Exhibition who works as an indigenous curator at Te Papa

- $\quad$ Meka Whaitiri, Chief Executive Officer of Ngāti Kahungunu Iwi Inc.

- $\quad$ Ngahiwi Tomoana, Chairman of Ngāti Kahungunu Iwi Inc.

- Dr Monty Soutar, former Chief Executive Officer of Te Rūnanga o Ngāti Porou and tribal historian

- Jody Wyllie, tribal member of Rongowhakaata who is leading the Te Hau ki Türanga Restoration Plan

- $\quad$ Mark Kopua, tribal member of Te Aitanga-a-Hauiti, and well-known tā moko artist

- Dr Wayne Ngata, tribal member of Te Aitanga-a-Hauiti, and leader of the Digital Repatriation projects of his tribe

- $\quad$ Professor Sid (Hirini) Moko Mead, Former Chairman of Te Rūnanga o Ngāti Awa, and Head of the Māori Studies Department at Victoria University, Wellington; one of the main organisers of the Te Mãori exhibition and leading figure in the return of the Mataatua wharenui to Whakatāne

\section{Tribal case studies}

A number of Māori tribal case studies have been undertaken to show how Māori identity was constructed and enacted within a Māori development framework. The case studies have been largely selected from contemporary Māori tribal development initiatives that have been, or still are, proceeding in the Waitangi Tribunal claim process. I decided to have tribal case studies that showed their involvement in heritage and arts activities, as these would provide useful examples from which to examine the relationship between taonga and their relationship to tribal identity and development. These tribal experiences provided the foundation for both empirical and qualitative information from which to seek answers to the research question. The case studies have been selected on the basis of their association with tribal development aspirations and their relationship to their cultural heritage. The tribal case studies also incorporate tribal taonga and cultural projects. The case studies range from tribes that have completed their Waitangi Tribunal claim to those embarking on it. Others had a strong involvement in tribal exhibitions, while some were involved in innovative technological and repatriation initiatives. The following case studies formed the basis of my qualitative and quantitative research. 
Ngāi Tahu is a tribe known for its development focus and futures imagining. This case study looked at the relationship between Ngāi Tahu and their cultural heritage with respect to their tribal development initiatives. The case study looked at the strategies and policies Ngāi Tahu have adopted over time with respect to their culture and development initiatives, as well as focusing on their tribal exhibition, Mō Tātou, ā, Mō kā uri a muri ake nei. The Ngāi Tahu Iwi exhibition was chosen in that it expressed the importance of Ngāi Tahu culture and identity, including its taonga, for its developmental future. The tour of this exhibition to Canterbury, Southland and Otago provided a good opportunity to examine identity constructions and the relationship between tribal taonga and their descendant source communities in their region.

An examination of the Ngāi Tahu tribal authority Te Rūnanga o Ngāi Tahu was also undertaken. Their strategies and visions, policies and practices, and heritage initiatives with respect to Ngāi Tahu identity and development were researched, documented and examined. The Ngāi Tahu tribal rūnanga has a number of policies, practices and initiatives that speak to tribal identity and, in particular, tribal development. The development initiatives of Te Rūnanga o Ngāi Tahu provided a solid foundation on which to examine the relationship between identity and development through the agency of taonga. Ngāi Tahu also completed their Waitangi Tribunal settlement and this offered an invaluable opportunity to reflect back to when they settled in the mid-1990s to their present vision in 2010 and beyond.

\section{The Ngāti Porou Tribal Authority and their Treaty of Waitangi claim}

The Ngāti Porou Treaty of Waitangi claim and letter of commitment (LOC) were also examined. The claim and LOC concerned Ngāti Porou taonga and focused on the care, management and access to Ngāti Porou taonga held in three institutions: Archives New Zealand, the National Library of New Zealand and Te Papa. The claim was advanced by the Ngāti Porou Waitangi Claim Negotiating Team Te Haeata and the three government agencies that hold the taonga.

This case study was chosen because it is a contemporary claim to the Waitangi Tribunal and it is one that directly relates to the relationship between Ngāti Porou taonga and Ngāti Porou identity within a tribal development framework. The claim was one of the first Waitangi claims that directly focused on a wide range of taonga held in government organizations. 
Like Ngāi Tahu, this case study provided a good opportunity to look at how Ngāti Porou position themselves for the future through their cultural heritage and identity strategies, policies and practices.

\section{The Ngāti Kahungunu Tribal Authority and Exhibitions}

The Ngāti Kahungunu Tribal Authority was examined along with a range of exhibitions pertaining to this tribe. The tribal authority was examined with respect to its visions and strategies regarding Ngāti Kahungunu cultural heritage and its development aspirations. This case study looked at the importance of this tribal exhibition within the context of Ngāti Kahungunu tribal identity and development. The tribal case study provided a good comparative example to the Mō Tâtou Ngāi Tahu exhibition, because it documented the importance of Ngāti Kahungunu taonga to both Ngāti Kahungunu tribal identity and development. The Kahungunu, Ka Moe, Ka Puta exhibition also travelled to venues within the Ngāti Kahungunu tribal rohe and this provided a great opportunity to delve more deeply into what this exhibition meant to the various areas and hapū (sub-tribes) within Ngāti Kahungunu. I personally experienced this exhibition and travelled to all the venues where this exhibition went, so there was a great opportunity to document its travels and impact within those areas.

\section{The Te Hau ki Türanga and Mataatua Wharenui}

Detailed accounts were also made with regard to two tribal meeting houses, Te Hau ki Türanga of Rongowhakaata and Mataatua of Ngāti Awa. These wharenui are both the subjects of Waitangi Tribunal claims and represent painful histories and past injustices and yet are symbols of a rejuvenated future for their tribal peoples. As large monumental taonga, they provide a good opportunity to examine their past history with its people and contemporary positioning with descendants of today.

An application was made to the Human Ethics Committee for approval to conduct this research. The research methodology raised a number of issues that were dealt with in accordance with the Association of Social Science Research code of ethics and the Privacy Act. Consent forms were used with all people doing interviews, in line with Victoria University Guidelines, and were explained to them. In most cases permission was given to deposit the tapes in the Victoria University library. The interviews were undertaken in places that were comfortable and agreeable to the interviewees, which included their homes, offices, 
Te Papa Tongarewa and offices in Wellington. Māori interviews were conducted in both Māori and English using appropriate tikanga Māori as a matter of course. The tapes were transcribed and sent to the interviewees. The transcriptions were analysed by identifying common themes and concepts in a matrix diagram, while differences were also noted as an important part of the research process.

\section{Outline}

Chapter One looks at Māori and museums in New Zealand and the nature of Māori tribal taonga. The Te Māori exhibition is then presented as a major case study, along with some tribal examples and their relationship to their taonga. Chapter Two looks at assertions of sovereignty and examines the notion of self-determination for indigenous and First Nation peoples and Māori as the tangata whenua of First Peoples of Aotearoa, New Zealand. This chapter looks at the politics of Māori tribal development, canvassing the key periods that characterized Māori development. Key themes and threads will be examined, along with the views of Māori development from iwi leaders.

Chapters Three and Four are detailed tribal case studies of Ngāi Tahu of the South Island and Ngāti Kahungunu of the East Coast of the North Island. These two chapters look at their tribal authority, along with their policies and processes, as well as a discussion of specific tribal taonga and cultural projects and exhibitions, including the Ngāi Tahu Mō Tātou, ā, mo ka uri a muri ake nei exhibition and the Ngāti Kahungunu exhibition Kahungunu, Ka Moe Ka Puta. Finally, Chapter Five looks at a mix of tribal initiatives, including the Te Hau ki Tūranga wharenui of Rongowhakaata, the Mataatua wharenui of Ngāti Awa, the Te Aitangaa-Hauiti tribal art projects, and the Ngāti Porou Treaty of Waitangi claim. These tribal taonga and cultural projects provide a wider mix to interrogate the thesis questions and propositions. 


\section{Chapter One: He Whare Taonga, He Mana Tangata - Māori Tribal Taonga}

\section{Introduction}

This chapter looks at museums in New Zealand and their relationships with Māori. It examines museum practice and iwi-Māori relationships with a focus on Māori tribal taonga. Museums have occupied a privileged space in the care, presentation and interpretation of Māori tribal taonga for well over 100 years. During this time relationships between Māori and museums have continued to evolve forward. Some museums, for example, were created in the late nineteenth century during the time of the New Zealand Wars and they operated within a colonial paradigm underpinned with western traditions of museum practice. ${ }^{1}$ This chapter explores the engagement between Māori and museums to ascertain key themes and practices.

This is then followed by an investigation of the nature and power of Māori taonga in anticipation of the tribal case studies that are presented in Chapters Three to Five. This section of the research seeks a better understanding of Māori taonga and their relationship to the wider culture. Some of the key questions are: why are taonga so powerful within the Māori world and what is it that enables them to be 'connected' through time and space to people, places and events, including myriad diverse historical and contemporary relationships? The interconnectedness of Māori tribal taonga to the broader culture provides the foundation on which to trace the agency of Māori tribal taonga in the context of their relationship to both Māori cultural identity and social and economic development.

At the end of this chapter the innovative international exhibition Te Mãori from 1984 to 1987 that travelled to the United States demonstrates the significance of Māori tribal taonga to their descendant source communities. Te Mãori became a watershed moment in New Zealand's history, leading to significant changes in the museum and art gallery community and reawakening Māori to their taonga. Te Māori highlighted the significance of Māori tribal taonga to Māori and through its success exposed outdated museum practices at that time. For Māori, the exhibition was largely a voyage of rediscovery. They were at the helm and everyone else was responding to the calls of the Kaihautū or Māori leaders of the exhibition.

1 The Auckland museum was founded in 1862 while others followed: Taranaki (1865), Hawke's Bay (1865), Wellington (1865), Otago (1868) and Canterbury (1870). 
The chapter will examine Te Mãori from its innovative cultural ownership processes through to the recognition of 'Mātauranga Māori' or Māori knowledge, tikanga, Māori customary concepts, and understandings of Māori taonga.

\section{From museums and Māori to Māori and museums}

Museums and galleries are repositories of thousands of treasures from different cultures and peoples throughout the world. Often viewed by Māori as colonial constructs, relics of colonisation and western imperial expansion, as the literature argued in the Introduction, museums are now facing enormous challenges to become more relevant and accessible and to engage more fully with their source communities. In other former settler colonies, these treasures have for many different societies become vitally important in the restoration, maintenance and revitalization of their cultural identity and cultural development aspirations. $^{2}$

The history of New Zealand museums and museum practice has its origins and foundation in the western tradition. As outlined in the literature review, New Zealand museums have been seen as colonial institutions based on European ideas, organizations and understanding of the world. Museums are also associated with imperial expansion and the colonization of indigenous peoples and their lands. ${ }^{3}$ New Zealand includes a diverse range of regional museums and four metropolitan museums, as well as specialist museums and art galleries. Certainly museums feature prominently within most of New Zealand's communities. Butts suggests: "Museums have never been more popular than they are at the beginning of the twenty-first century." However, today we are fortunate in that museum history and practice in New Zealand is increasingly better understood through the research and writing of academics, museum practitioners and others. ${ }^{5}$

The history of the relationships between Māori and New Zealand museums reveal a complexity and depth to New Zealand's colonial history and the indigenous response to that. For example, Butts has examined the governance relationships at the Tairāwhiti and Whanganui Regional museum, while McCarthy has documented the genealogy of exhibiting Māori from the mid-nineteenth century to the end of the twentieth century and the history of a

\footnotetext{
See Clavir, 2002; Crooke, 2008; Peers and Brown, 2003; Watson, 2007.

Henare, 2005.

Ibid. 203.

See Butts, 2002, 2003, 2007; McCarthy, 2004, 2007, 2009.
} 
number of tribal exhibitions and projects at Te Papa. There is no doubt that colonization has impacted significantly on Māori, but McCarthy believes that there has been an over-emphasis on the colonial encounter with a denial of Māori agency that shows a continuous relationship with Māori over a long period of time. McCarthy describes this as the 'revisionist history of indigenous interaction with museums'. ${ }^{6}$ In the 1990s, Gerard O'Regan and Hinehaea Murphy also examined the state of museums and their relationships with Māori, commenting on bicultural museum practices, tikanga and Māori staffing levels, as well as providing directions for the future. ${ }^{7}$

The research on museums and Māori has increased exponentially over the last few decades as Māori advanced their plans for self-determination and envisioned a future where their taonga and cultural heritage are given prominence. ${ }^{8}$ Scholars Sidney (Hirini) Moko Mead and Paul Tapsell provide a Māori history of museums and interactions with indigenous people offering insider Māori tribal perspectives with regard to Māori tribal taonga. Mead is a noted authority on Māori art and culture and was the curator and co-leader of the Te Māori exhibition.

Tapsell is a Māori academic and former museum leader who writes from a Te Arawa tribal perspective on Te Arawa taonga. Both have contributed to the literature on Māori and museums, offering pathways towards more enlightened museum practice. ${ }^{9}$ Mead has been highly critical of museum practice in New Zealand. His advocacy for the reclamation of Māori taonga remains as relevant today as it was 20 years ago:

One way of recapturing one's culture is to take control of the language of definitions and descriptions and to have members of the culture speak for themselves, present their culture such as their music, their dances and their various art forms in a manner they consider appropriate to them. ${ }^{10}$

Another important commentator on museums was the Shane Jones. Jones, writing in 1994, argued that museums have not served Māori well and that they "are for Pakeha professionals

McCarthy, 2011.

Murphy, Hinehaea. 1999. Bicultural Developments in Museums of Aotearoa - A Way Forward: Te Kaupapa Tikanga-a-rua ki roto i nga Whare Taonga o Aotearoa - Anei ko te Huarahi. Wellington: Museum of New Zealand Te Papa Tongarewa.; O'Regan, 1997.

8 Butts, David. 2000. "Museums". In Informing New Zealand: Libraries, Archives and Museums, edited by R McCahon and G Oliver, 150-160. Wellington: Open Mind Publishing.; Cameron, 2000; McCarthy, 2004, 2007, 2011; Mead, 1983, 1985, 1986, 1990, 1993; Tapsell, Paul. 1995. Taonga and Obligations of Reciprocity. MA, Auckland University, Auckland.; Tapsell, 1997, 1998, 2000, 2003, 2006, 2011.

9 See Mead, 1985, 1997; Tapsell, 2002, 2011.

10 Mead, 1990, 165. 
who have the time and expertise to interpret the objects of the past." ${ }^{, 11}$ Jones says that museum control of, and interpretation of, taonga Māori has widened the gap between the Māori and their taonga tuku iho (the treasures handed down from the ancestors). He maintains that a 'living' culture requires access to such treasures if they are to be effectively integrated into contemporary Māori life. ${ }^{12}$

The connectivity that exists between Māori and their cultural heritage reinforces the enduring whakapapa relationships that are so critical to Māori tribal identity. Taonga are not relegated to the historic past, because for Māori people they have an ongoing significance for the future. Given the legacy of colonialism and the subsequent loss of knowledge, taonga have become even more important as bridges to the recovery and reclamation of that knowledge in the life of the people today and into the future. They are sites of 'intersecting histories'. ${ }^{13}$ As Peers and Brown note:

... artefacts have overlapping, but different, sets of meanings to museums and source communities - and tend to be interpreted very differently by each group. Particularly for indigenous peoples, for ... They are also crucial bridges to the future. For peoples whose way of life has changed dramatically but whose identity rests on historical cultural knowledge, artefacts offer the possibility of recovering a broad range of cultural knowledge for use in the present and future. ${ }^{14}$

This link to cultural futures is a key theme that has encouraged consultation and engagement leading to more active Māori participation in museums. ${ }^{15}$ The balance between recognizing the rights and responsibilities of mana whenua and mana taonga is important. Museum professional Mere Whaanga reminds us about the significance of mana taonga relationships with the waka taua (war canoe) Te Toki-a-Tāpiri at the Auckland Museum:

Meanwhile, Te Toki a Tapiri resides in an institution devoid of contact with its rightful Kaitiaki - those able to whakapapa to Tapiri who have been appointed to Ngāi Tahu Matawhaiti to fulfill that role. However interesting a display may be, it undermines the nature and meaning of taonga if it negates, or even ignores, the relationships that give life to material forms. ${ }^{16}$

11 Jones, Shane. 1994. "Museums and the Treaty of Waitangi". In A Framework for Funding and Performance Measurement of Museums in New Zealand. Museum Directors Federation, Taonga o Aotearoa National Services of the Museums of New Zealand. 77.

12 Ibid. 78.

13 Edwards, 2010.

14 Peers and Brown, 2003. 5.

15 Gorbey, 1991; Gurian, 2005, 2006; Hakiwai, 1994, 2005, 2008; Henare, 2005; Kawharu, 2002; McCarthy, 2007; Mead, 1984, 1985, 1990, 1993; Simpson, 1996; Sully, 2007; Te Awekotuku and Nikora, 2003; Thomas, 1991, 1995, 1999; Thomas and Adams, 2009.

16 Whaanga, 2004, 233. 
This area, however, is not all plain sailing, as some believe museums have adopted policies and processes that are counter to recognizing the mana whenua or authority of the local tribes where the museum resides. ${ }^{17}$ Te Papa's mana taonga policy and its application for the Rongomaraeroa marae at Te Papa is one such example that Tapsell believes cuts across Treaty principles and the mana and authority of the mana whenua or local tribal authority. When a group of Te Arawa arrived at the museum in 1992 they were not welcomed by the local iwi and they were not allowed to perform their customary trusteeship role or Rangatiratanga. ${ }^{18}$

\section{Māori tribal taonga}

The modern pepehā or proverb created for the Te Māori exhibition in the 1980s 'He Toi Whakairo, He Mana Tangata' (Where there is artistic excellence, there is human dignity) is a reflection that shows the interconnectedness and relationship between taonga and Māori identity. The association of artistry or artistic practice with the human dimension conveys to the world the connectedness taonga have to the culture and in this case Māori culture.

Certainly with respect to the Te Mãori exhibition the world saw and experienced the power of Māori taonga and their close relationship with their descendant source communities.

Much has been written on taonga and the nature and characteristics of taonga. The importance of taonga to Māori people has been well documented. ${ }^{19}$ Amiria Henare cites the well-known writing of Māori Marsden when she writes that the Māori idea of value is incorporated into the term 'taonga'. Taonga is a treasure, something precious; hence, an object of good or value. The object or end valued may be tangible or intangible, material or spiritual. ${ }^{20}$ Henare reminds us that taonga could be an historic whalebone club, the Treaty of Waitangi, a native plant, a body of knowledge, or women and children. ${ }^{21}$ Mead positions taonga as an integral part of the wider culture within the continuity and connection of past, present and future:

We treat our artwork as people because many of them represent our ancestors who for us are real persons. Though they died generations ago they live in our memories and we live with them for they are an essential part of our identity as Māori individuals. They are

17 It is customary practice for Māori to recognize the mana of local tribes whenever you enter into another tribal territory.

18 See Tapsell, 2004, 272.

19 See Butts, 2002, 2003; Davidson, 1989; Mead, 1984, 1986b, 1990, 1993, 2003; Tapsell, 1995, 1996, 1998, 2000, 2006.

20 Henare, 2007. 57. (Original cited in Royal, 2003, 38.)

21 Ibid. 
anchor points in our genealogies and in our history. Without them we have no position in society and we have no social reality. We form with them the social universe of Māoridom. We are the past and the present and together we face the future. ${ }^{22}$

An important dimension of Māori taonga is the kōrero or their story or narrative. Mead emphasises the importance of kōrero:

\begin{abstract}
All objects that are called taonga have kōrero attached to them. The kōrero is a valuable aspect of any taonga and it is the kōrero that gives meaning and cultural significance to it. Kōrero enriches the taonga, enhances it, provides it with a history and links it very strongly to a particular social group such as a whānau, hapū or iwi who have cultural rights not only to the kōrero but also to the taonga itself. Providing kōrero is an expected part of the process of creating taonga. ${ }^{23}$
\end{abstract}

Writing on the identity boundaries of the southern tribes Waitaha, Kāti Mamoe and Kai Tahu, Waymouth advocates that taonga are firmly connected to Māori tribal identity, because they have a whakapapa and connection to people and places:

In terms of identity, taonga establish the group's identity and their links to a particular region and resources. Surrounding each taonga are images of tipuna, places of importance and spiritual concepts, each weaving strands of identity that make up the framework of the Kaitiaki group's existence. Tapsell describes this as "eliciting a strong emotional response" which is driven by the underlying force of whakapapa. ${ }^{24}$ The whakapapa dimension is encompassed within the words "taonga tuku iho", that is, the gift passed down from the ancestors. This gift may be a material object, such as a mere, or a story explaining the origins of a particular place name connected with a tipuna (ancestor). In either case, the connection with the contemporary group and the past is through the whakapapa of that group: their ancestral links to that particular taonga which gives them the recognized authority and ownership. ${ }^{25}$

Mead informs us that the most telling aspect of taonga is their taha wairua or spiritual dimension, essentially this is the difference between artifact and taonga as he explains: "The most telling attribute of taonga is their spiritual essence or force." He continues:

This is a quality which is described in the korero associated with a taonga and which one accepts or rejects according to one's experience and faith... Today we speak of 'taha wairua' that is the spiritual aspect and it is generally acknowledged that a major difference between 'artefact' and 'taonga' is that there is a taha wairua to the Māori concept. ${ }^{26}$

\title{
Mead, 1985a. 13.
}

Mead, 1990, 164-169.

Tapsell, 1997, 326.

25 Waymouth, Lynette Joy. 1998. Waitaha, Katimamoe, Kaitahu: Ko Wai? Waitaha, Katimamoe, Kaitahu: Identity Boundaries. MA, Māori Studies, Auckland, Auckland. 22.

26 See Waitangi Tribunal Wai 262 Report 2011, 81. See also Mead, 1990, 166.; Mead, Sidney (Hirini) Moko 1986. “Art Objects as Taonga: Spiritual Values and Power in Māori Art". Field Museum of Natural History Bulletin no. 57 (2):6-10; 19-23. 
For Mead one of the reasons why taonga have a spiritual dimension is that they represent an ancestor who is connected by whakapapa or genealogy to a group of descendants. ${ }^{27}$ During the Te Mãori exhibition it was a common experience for the guides to embrace and talk to their ancestors or lay green leaves at the feet of their ancestors. When taonga have great mana and tapu their spiritual power is increased. Likewise, the mana of taonga is increased if the taonga has great antiquity, its korero or history is significant, it has a strong relationship or association with its descendant kin community or it has an association with death. ${ }^{28}$

An important dimension of Māori taonga is that there exists a mauri or life force or life principle. Manuka Arnold Henare describes this as the philosophy of Māori vitalism and defines this as "the belief in an original singular source of life in which life continues as a force, which imbues and animates all forms and things of the cosmos." ${ }^{29}$ For Henare, Māori vitalism is expressed in Māori terms such as tapu, mana, mauri, hau and wairua and these terms have multiple meanings where the context in which they are used clarifies the metaphysical and spiritual intention. ${ }^{30}$ An example of this is demonstrated in a letter written by a Māori elder of Ngāti Raukawa Tamati Ranapiri in 1890 and later translated by Elsdon Best. In the letter, Ranapiri describes how when a treasure is exchanged it carries with it the hau or 'spirit of the gift', an animate force binding those involved in the transaction - person and things - into a cycle of reciprocity. ${ }^{31}$ Henare also cites the example of gifts presented to Governor George Grey and how the chiefs were hongi-ing them and mingling their own hau or breath of life with the object-ancestor. ${ }^{32}$

Manuka describes the process of training for artists in the traditional schools of learning and how patterns like chevrons and double spirals in the spirals depict the unfolding of the cosmos and other dynamic forces. ${ }^{33}$ Regarding Māori art, Henare says, "Māori art is vitalistic in its expression of religion and philosophy, particularly where it is the intention of the artist to enhance vital potential." ${ }^{34}$ Salmon also notes the importance of vitality and says that, "In

27 See Mead 1990, 166.

28 Ibid. Mead cites the example of Uenuku being a taonga with great mana and tapu given its korero and association with Queen Te Atairangikaahu and the large Tainui-Waikato tribe.

29 See Henare, Manuka. 2003. The Changing Images of Nineteenth Century Māori Society - From tribes to nation. PhD, Māori Studies, Victoria University of Wellington. Wellington. 32.

30 Ibid. Royal (2009) believes taonga like the celebrated adze Te Awhiorangi and Uenuku are not only the accoutrements for the actors in cosmic dramas, but form tangible proof that mythical time and space exist. As remnants of primordial events, they are replete with transformative power. (p.56).

31 See Amiria Henare, 2007a, 57.

32 Ibid, 68. See also Henare, 2003, 101-106 for a more detailed account of Ranapiri's letters.

33 Ibid, 37.

34 Ibid. 
Māori a person's whakapapa (often glossed as genealogy), makes them the 'living face' of their ancestors, an element in a network of ties of descent and other relationships whose vitality endures in Te Ao Marama, 'the world of light' through their identity and form". ${ }^{35}$ Anne Salmond has observed that taonga is a "fixed point in the tribal network of names, histories, and relationships" and that they connected the living with the dead in such things as waiata, proverbs, heirlooms and garments. ${ }^{36}$

Māori treasures have trajectories that have taken them away from their source communities and ancestral lands to distant lands and foreign peoples. The displacement, dislocation and alienation of these taonga from their place of origin and source communities have created 'arenas' for Māori seeking to maintain and revitalize their cultural identity. Located largely in the basements of museums and galleries both within New Zealand and overseas, these taonga have been objectified and removed from their kinship contexts for over 100 years and many have not been seen or 'experienced' by their descendant source communities. ${ }^{37}$

Paul Tapsell has written about taonga from the perspective of a Te Arawa tribal member, museum worker and academic. Tapsell writes about the pathways and trajectories of taonga and how the mauri or life essence of taonga was protected through ritual to maintain physical and spiritual security of taonga on their travels. "Both Pareraututu and Murirangaranga offer first-hand accounts of the identity-binding power taonga can ritually release if performed in the right contexts", ${ }^{38}$ he points out. For Tapsell, "taonga are time travellers that bridge the generations, enabling descendants to ritually meet their ancestors face to face."39 Tapsell developed a Māori terminology and meta-data of taonga based on his discussions with Te Arawa elders. His adoption of the tui and comet metaphor for the flight of the tui and the orbital path of the comet express the nature of taonga for Te Arawa people. Tapsell is very direct about his 'lived' experience and the 'recentring' of the academic discussions - it was about tribal context from the people as opposed to impartial observers who rely on ethnographic texts. "Today, these powerful symbols of tribal identity not only endure," he

See Amiria Henare, 2007a, 57. (Original cited in Salmond 1995: 26).

36 See McCarthy, 2007, 28. (Original cited by Salmond in Mead 1984: 118).

37 Tapsell, 1996, 1997, 1998, 2006.

38 Tapsell, 2006, 15.

39 Tapsell, 2006, 17. 
writes, "but remain inseparably layered within a wider genealogical cloak of knowledge which shrouds the whole of late $20^{\text {th }}$ century Aotearoa-New Zealand in a living ancestral past." 40

Protecting and nurturing taonga within the context of customary Māori values is critically important. Values such as mana, tapu and korero are in fact intrinsically important to the understanding of taonga. Tapsell explains this concept further:

In modern contexts the ongoing protection of taonga - associated values of mana (customary authority, prestige), tapu (restricted, set apart, associated with ancestors) and korero (narrative, story) remains just as important, be it in an elder's closet or on display in an international museum. If these three values have been maintained and protected, it is understood the ancestral presence of the taonga is intact and its journey ongoing. ${ }^{41}$

For Tapsell then, tribal values of mana, tapu and korero are critical in understanding taonga. For him, histories are re-lived, taonga renourished and the genealogical narratives continue through their marae and ritual contexts. ${ }^{42}$ Taonga, according to Tapsell, are not limited to carved or weaved items, as "they can also take the form of a song, a geothermal hot pool or a photograph. What is important is the ancestor-descendant connection, the relationship between kin group, their lands and resources (represented by taonga) and the customary context in which it all makes sense: the marae. ${ }^{, 43}$ He believes that the customary value of taonga is measured in terms of mana, tapu and korero "which must remain intact if its descendants are to glimpse their ancestral selves in its depths." ${ }^{\text {"4 }}$ In relation to these ancestral values, Tapsell describes them as follows:

Mana is the ancestral power of the gods, tapu is the spiritual order that protects them so that they can travel through the generations, and korero is the knowledge - the oral traditions, the prayers and the words - embodied in taonga that nourishes the mauri, or life-force, of each such item. ${ }^{45}$

Tapsell often reminds us of the nature of taonga to collapse time and space where you literally meet your ancestors face to face. He also describes the exhilaration when you encounter and experience this: "Descendants experience this wairua (ancestral spirit) as ihi (presence), wehi (awe) and wana (authority). Mead also writes about the power, awesomeness and authority of works as described by the terms ihi, wehi and wana: "some

\footnotetext{
40 Tapsell, 1997, 325.

41 Tapsell, 2003, 246.

42 Tapsell, 2006, 89.

43 Ibid.

44 Tapsell, 1997, 331.

45 Tapsell, 2006, 89.
} 
taonga are so beautiful that everyone agrees that the artist reached the ultimate heights of creativity which our ancestors described as the three-in-one concept - ihi, wehi, wana." ${ }^{46}$

Referring to the exhibition Ko Tawa that Tapsell helped organise, he notes that reconnecting kin with their taonga creates a set of responsibilities and obligations for both museums and tribal members and that this has implications for identity. "By returning to home marae," he argues, "the ancestors of Ko Tawa are again able to offer descendants a sense of identity, inspiration and belonging...At the same time the stories wrapping around the taonga can come back to life." Tapsell reminds us of the recontextualisation of taonga when they are returned home to their people when he says: "In a world increasingly shaped by values of private property and ownership, museums have significance, more so when they reach beyond their walls into communities." ${ }^{47}$

Writing about the Gilbert Mair taonga, Jade Baker, a tribal researcher of Ngāti Awa, notes the importance of taonga in contemporary times as holding iwi-specific knowledge and as markers that reconnect to the times, events and ancestors that were engaged in tribal politics and history. ${ }^{48}$

\section{The role of taonga in traditional Māori society}

The role and place of taonga in traditional Māori society are well documented and this is very evident in the claims brought before the Waitangi Tribunal. ${ }^{49}$ What the historical records tell us is that taonga played a key role in traditional Māori society. Mead reminds us that for over 1000 years Māori lived on our islands, sharing an intimate relationship with the land.

Regulated by tapu and whakapapa, the distinctive visual arts evolved. They were shaped by the environment and as Mead notes, "Historically, Māori did not separate their creations into art, artefacts or culture: creativity superceded such classifications. Taonga, now admired as

46 See Mead, 1990, 168. Mead gives the examples of the Te Kaha 'Te Potaka' pataka, Patetonga lintel and the Te Atiawa carvings found in the swamps at Waitara, Taranaki. Manuka Henare (2003) cites the example of elders visiting the Sistine Chapel in Vatican City in 1988 and how they were overcome with the ihi, wehi and wana (awesome power and strength) of seeing Michelangelo's painted ceiling depicting the biblical account of the transmission of life (p.37).

47 Ibid. 15.

48 Baker, Jade Tangiahua. 2009. "Te Kupenga: Re-casting entangled networks". The Australian Journal of Anthropology no. 20:125. Baker also says that interpreted through the perspective of an iwi researcher "taonga are not passive sites of this information but reflect multiple complexities as subjects in these relationships" (p.125).

49 See Mead, 1990, 1998; Neich, 2001; Royal, 2004; Salmond, 1983; Tapsell, 1997, 2011. 
art, were originally created for practical purposes but were also associated with the terms mana (prestige), tapu (highly valued and restricted) and whakapapa (genealogy)., ${ }^{, 50}$

Tapsell points out that Te Arawa taonga are time travellers and represent actual ancestors:

Layers of ancestral knowledge - whakapapa - were contextually narrated, collapsing genealogical time so that now it was me who is fetching Te Kaoreore; or landing at Ongatoro; or playing Murirangaranga; or retrieving Kaitangata or taking a fatal musket ball in my hips. Taonga are our time-travelers. They made real not only the ancestors, but also their surrounding landscapes by burying a sense of ancestral belonging deep into our living core. These taonga were present during tribe-defining moments of crisis; they played key roles alongside key ancestors. In time, such taonga do not just represent ancestors, they become those ancestors. ${ }^{51}$

Reaffirming key moments in tribal history is an important dimension of Māori taonga as Tapsell notes, "taonga performed a core function in Māori tribal society; they marked key ancestral moments at a particular place, representing successful amelioration of life crises in the face of potential kin-extinction." 52

The roles that tribal taonga play in the Māori world show a multiplicity of dimensions and emphasize that taonga represent 'the art of relationships, past, present and future. ${ }^{53} \mathrm{In}$ relation to Te Arawa tribal taonga, Tapsell notes that there tribal oral traditions indicate that "tribally valued taonga were mostly released, received or exchanged as representations of a mutually binding contract to settle past hostilities with a bordering kin group." ${ }^{, 54}$ As also noted by Henare, "The exchange of taonga in Māori has long been an integral part of the work of relating, and continues to be so in the present.",55

Additional key Māori values like kaitiakitanga (cultural guardianship), whakapapa (genealogical relationships) and turangawaewae (a place to stand) should also be understood within the context of taonga reconnection. These values will form a critical path on which to

S0 See, Mead 1999.

51 Tapsell, 2011, 10. Tapsell also reminds us that works of art and taonga represent the art of relationships both past, present and future (p.49).

52 See Tapsell, 2011, 12.

53 Ibid.

54 Tapsell, 1997, 338.

55 Henare, Amiria. 2007. "Taonga Māori: Encompassing Rights and Property in New Zealand". In Thinking through Things: Theorising Artefacts in Ethnographically, edited by Amiria Henare, Martin Holbraad and Sari Wastell, 47-67. London and New York: Routledge. 60. 
examine constructions of Māori identity and development. ${ }^{56}$ Henare writes about taonga and objectification where the form of taonga is inherently productive and reproductive, as they both arise from and are generative of relations. ${ }^{57}$ Amiria Henare refers to the complex relational matrices of taonga:

... treasured taonga were exchanged in order to establish and maintain intra- or intertribal relationships, were already long established among Māori, and have ever since been a central feature of Māori life. They formed alliances between warring tribes, established new ties between strangers, and revitalised relationships that had gone cold. The kinds of taonga exchanged could include women and green stone valuables. Usually, however, taonga were passed down within kin groups, acting as (often tangible) instantiations of relationships extending across multiple generations. ${ }^{58}$

It is certain that taonga are being involved in the discussions and claims process of the Waitangi Tribunal hearings with a particular emphasis on cultural redress. Tribes are seeking restorative provisions and access and control over their taonga and are presenting to the government their understanding of tribal taonga. The Te Roroa Waitangi Tribunal Report was completed in 1992 and offers a good glimpse into a tribal relationship with their cultural treasures. Outlined in the Te Roroa Report was the European and Māori perspectives of taonga and these are stated here as they are pertinent to this doctoral research:

Modern European views of the natural world and natural resources are essentially scientific. For the purposes of study and research scientists divide the whole into its component parts and classify the parts. In other words, they do not share the Māori view of the unity of people and the treasures they produce, with the land and the cosmos. Nor do they share the Māori view that "Names, knowledge, ancestors, treasures, and land are so closely intertwined ... that they should never be separated."

The report notes that until recently few questioned the right of museums to collect cultural and natural treasures of others and cited legislation like the Māori Antiquities Act 1901 as law that provided for the protection and preservation of taonga. The appropriating tendencies of an emerging "One New Zealand" was noted in the report:

\footnotetext{
56 The Waitangi Tribunal Wai 262 Report (2011) noted that the core Māori value of kaitiakitanga was central to the claim and defined 'kaitiaki' as 'those whose special relationship with a taonga gives rise to an obligation and corresponding right to protect, control, use, preserve, or transmit the taonga itself and also the relationship of kaitiaki to the taonga" (p.7).

57 Henare, 2007a, 62.

58 Henare, 2007a, 57.

59 See Te Roroa Waitangi Tribunal Report 6.3 - The European Perspective.
} 
Underlying this legislation was the official and public view that Māori taonga were part of the national heritage which should be preserved for scientific research, art appreciation and public interest. This meant the separation of taonga from the people and land to which they were related for safe storage in museums. It also meant they would be managed and controlled by public bodies and that the public would have access to them. ${ }^{60}$

The Te Roroa tribal perspective for taonga graphically illustrates their significance and the role they play in the lives of the people:

Taonga is an umbrella term, inclusive of a wide range of things upon which Māori in general and the whatu-ora (claimants) of this claim place great value and regard as treasures. Among them are intangibles like spiritual values as well as tangible objects. \{FNREF:0-86472-088-2:6.2:3\} They include the land, sea fronts, forests, lakes and rivers; also places and things associated with life and death. Although the degree of tapu varies, all these taonga touch the "heart", the manawa pa (desires) and ngakau pa (ends) of the people (B24:15). ${ }^{61}$

The physical presence recalls the name. The name recalls the event. The event recalls the whakapapa. The whakapapa recalls the connection between things past and things present. The connection between things past and things present is the element which gives Te Roroa its pride and identity (I1(e):69-70). ${ }^{62}$

The claimants of Te Roroa believe that their mana whenua over areas which contain taonga like wāhi tapu requires the fulfilment of certain obligations. There is the right as well as the duty to 'keep warm' the taonga within the rohe. The relational nature of Māori taonga to the people, to the land and to the wider culture largely through whakapapa is a dimension expressed by many Māori.

Throughout the Waitangi Tribunal Reports, it can be seen that Māori taonga have a strong and integral relationship to the wider culture. Taonga often include the language, beliefs, tangible and intangible heritage, the land and those important treasures valued by the people. This relationship is very similar to the relationship that indigenous peoples have with their material culture, as Butts notes:

For aboriginal people, culture encompasses much more than the objects, but the objects cannot easily be separated from culture. It is more a case of which people belong to and with their particular culture, which includes the languages, beliefs and objects. In Euro Canadian terms, people own their 'heritage'. In aboriginal terms, the culture 'owns' the people. $^{63}$

\footnotetext{
60 Ibid.

61 Te Roroa Waitangi Report 6.2 Te Roroa Perspective.

62 Ibid.

63 See Butts, 2003, 55. The original reference is Doxtator (1996: 67).
} 
Taonga are used in a wide range of tikanga situations and have been placed before Waitangi Tribunal hearings as part of the claim environment, bringing to the fore tribal histories and accounts. In writing about mātauranga Māori and museum practice, Charles Royal notes tikanga associated with taonga, such as kopaki, takai, tiwha and manatunga. In these circumstances, taonga are used to discuss important issues, provide affection and reverence for the occasion or to recount and uplift tribal history and identity. Royal gives the example of a kopaki when a taonga was laid down on a Muaupoko marae in preparation of the Ngāti Raukawa ki-te-tonga Waitangi Claim in the early 1990s. ${ }^{64}$

For many, the cultural dimensions are all-pervasive for the future development of Māori people and Māori taonga have an active role to play in contemporary society. As Tāriana Tūria, the Māori Member of Parliament reminds us: "It is the living relationships that give meaning and cultural value to a taonga, and enable the taonga to fulfil its function of reinforcing the mana and identity and tikanga of the community. In the past, many of our taonga have been kidnapped." 65 The active role that taonga play in the lives of Māori tribal people is a strong dimension shared by many other writers and academics. ${ }^{66}$ Baker cites the example of how traditions of gifting taonga or tuku taonga have continued into modern times when a wakahuia or treasure box was presented to the owner of the land where Ngāti Awa erected a pouwhakamaharatanga in remembrance of the raupatu in $1865 .{ }^{67}$

In the literature review, Charles Royal noted that museums and taonga encapsulate key elements of a development framework that is based on the restoration and revitalization of Māori knowledge and culture. ${ }^{68}$ For Royal, the power of taonga and their knowledge is in their ability to be relevant in today's world: "The question is not merely one of capturing traditional perspectives on life - and how these are expressed through taonga - but how these traditional perspectives might evolve to inform new perspectives in touch with our experience of life today." ${ }^{69}$ Mead has similar views and believes that mātauranga Māori is an embracing

\footnotetext{
See Royal, 2004.

Tūria, 2002. Matariki, and Māori Cultural Heritage. New Zealand Government.

66 See Hakiwai, 1994, 2008; Mead, 1986, 1990, 1997; Simpson, 2009; Tapsell, 2000, 2006.

67 Baker, 2009, 124.

68 Royal, 2004.

69 Ibid. 39.
} 
and inclusive term that has a past, present and future and that "we are now reshaping, rebuilding, reinterpreting and reincorporating elements of mātauranga Māori to make it fit the world that we live in today."70

Bernard Makoare shares similar views to Royal in relation to Māori records and archives and believes these are taonga to be shared, passed down and added to as part of a continuing shaping of the culture. As Makoare says:

Therefore, the ownership or connection to information that is imperative to the cultural identity of Māori is not for any one person to own, per se. Each generation, in Māori understanding, has the responsibility to keep the integrity of the memories about the past people and their actions and to add to these in the continuous and dynamic shaping of the culture. $^{71}$

The comments made by the museum commentator Barbara Kirshenblatt-Gimblett in the Introduction regarding the life-force of taonga take on renewed attention for this chapter as the power of taonga to be given 'life' from their descendant kin communities was a dimension that was reaffirmed with the Te Māori exhibition. ${ }^{72}$ To understand taonga one must have an understanding of the Māori world - te ao Māori - because taonga are so intimately connected with Māori knowledge, values and tikanga. Some tikanga lies at the heart of Māori society and is dynamic and unique to Māori. Tapsell argues that to understand the role that taonga might yet play in the future, especially within institutions of memory or nation spaces, we "first need to understand the art of taonga from a kin-accountability, Māori historical perspective." ${ }^{, 73}$ Tapsell raises the question whether or not taonga will ever come to represent the dynamic tribal values or “remain captured by museum's ever-changing ways of thinking.",74

This interconnectedness and the importance of taonga's korero and history is expressed by Butts in the following way:

Taonga exist at the centre of complex interconnected webs of relationships in the same way that individuals are positioned within interconnecting webs of whakapapa. An important factor in the ability of taonga to remain active within these webs of

70 Mead, 2012, 11, 14. Mead further notes that mātauranga Māori is inclusive and allows for innovative ideas and practices. He cites the example of modern technology used to carve tiki from greenstone and bone (p.14).

71 Makoare, 1999, 23.

72 See Kirshenblatt-Gimblett, 1998; Mead, 1984.

73 Tapsell, 2011, 20. Tapsell believes that having such contextual knowledge will better arm us in the tracking of trajectories of taonga.

74 Ibid. 
relationships, perhaps even to re-activate them, is the retention of their kōrero: the knowledge of their history and their whakapapa. These webs of relationships surrounding taonga held in museums include links to those who created the taonga, those who are customary kaitiaki, the wider group of people who have used the taonga or who can whakapapa to the taonga, those who care for the taonga in the museum context, and those visitors who see/experience the taonga when they visit the museum. ${ }^{75}$

Today, taonga has taken on the general meaning of 'treasures', but this is far too simplistic. McCarthy reminds us that taonga can be defined as treasures of Māori and cultural heritage that encompass things like the natural environment, people, objects and non-material entities. ${ }^{76}$ He further notes that taonga collapse spatial and temporal boundaries and blur the western separation of the material and immaterial worlds. ${ }^{77}$ An interesting perspective that McCarthy notes is the apparent change in how the word 'taonga' has been used since the early 1800s. Based on early English dictionaries and texts, taonga stressed the notion of 'property' or 'highly prized' where from the late nineteenth century to the early twentieth century the meaning drifted to one of 'treasure' ${ }^{78}$ In looking at the flight of two Te Arawa taonga, Pareraututu and Murirangaranga, Tapsell makes the point that taonga have not been properly understood or credited with any major importance by outside observers. Instead they have given cursory definitions like 'heirloom' or 'property' ${ }^{79}$

It is clear from the writing and from lived Māori experience that tribal taonga represent a wide array of relationships that holistically show their power. Under the heading 'The Art of Taonga', Tapsell mentions a large number of areas that taonga relate to. These domains are important when we consider the proposition of what is the nature of taonga. The Art of Taonga categories as proposed by Tapsell are worth noting: origination, relationships, exploration, boundaries, protection, collecting, reciprocity, colonization, confiscation, betrayal, death, citizenship, (dis)integration, nationhood, belonging, and accountability. ${ }^{80}$ Relationships lie at the heart of our understanding of Māori tribal taonga and they connect the past with the present and future. As Tapsell puts it: "Much more than works of art, taonga represent the art of relationships: past, present and future. From the earth to the heavens; from

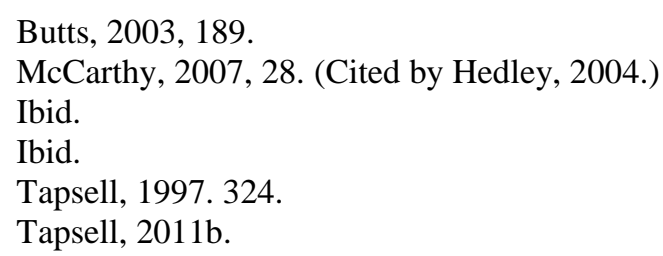


distant ancestors to those yet to be born; from a Pacific culture of exploration to deadly engagements with external threats; taonga epitomise all that is valued in Māori." ${ }^{\prime 1}$

\section{Diagrammatic representation of the interconnectedness of taonga}

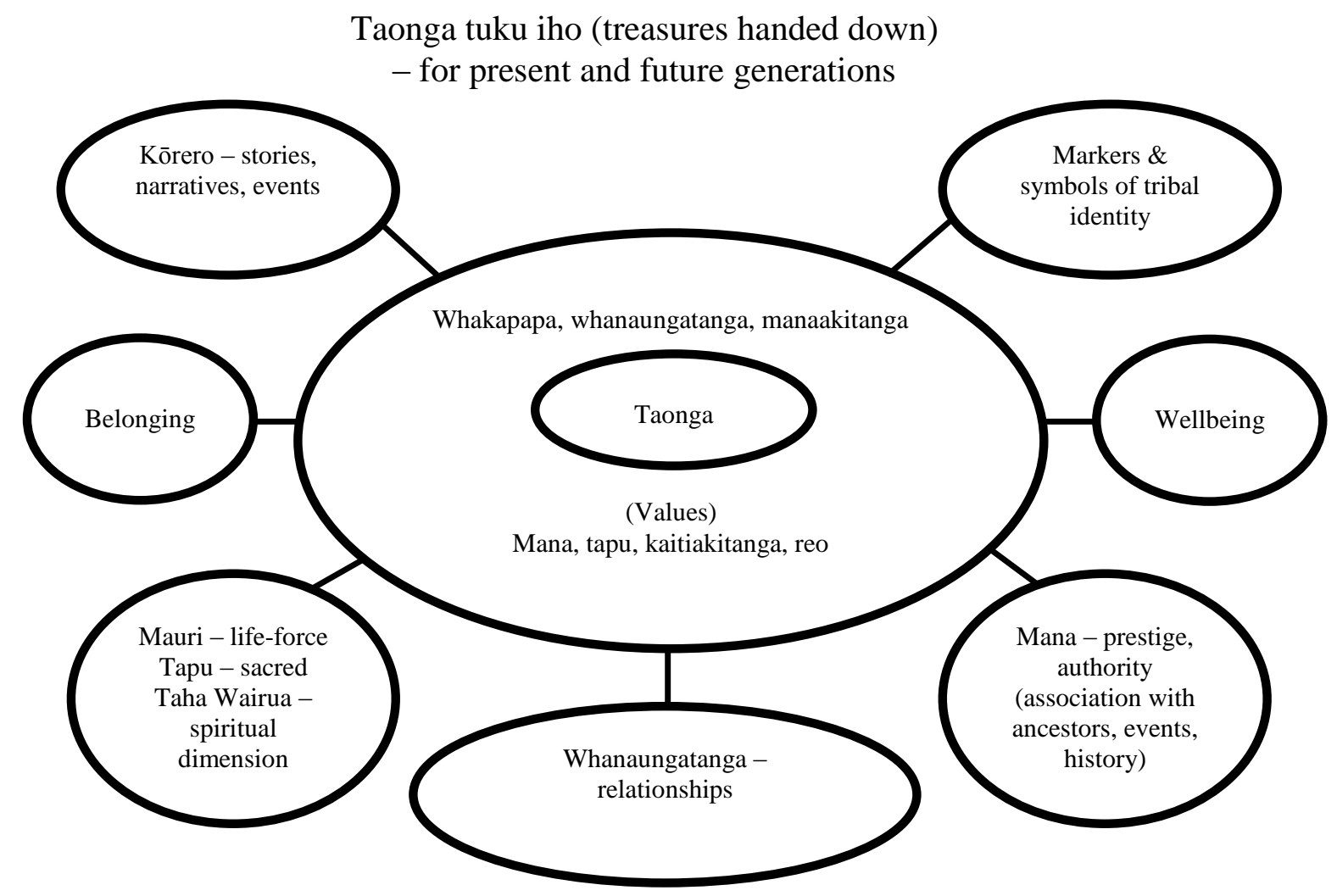

Taonga represent symbols of tribal identity and form an array of relationships connecting the past to the present and future. This diagram draws on an understanding of Māori tribal taonga within the Māori world. It adopts key Māori concepts and values, such as mana and whakapapa, in a way that communicates the power and value of taonga. The diagram synthesizes the views of Māori authorities and tribal members to show the interconnectedness of taonga to the culture and draws on other diagrammatic representations of Māori identity and the Māori world, such as that of the 'He Tihi Tangata' diagram of Higgins and the 'Whare Tapa Wha' model of Durie. ${ }^{82}$

81 Ibid. 49.

82 See Higgins, 2004, 16, 337. Higgins' model adopts the niho taniwha pattern as representative of the mana of the people and uses mana atua, mana tangata and mana whenua to express the Māori collective identity. Durie's (1998) model represents the four corners of a whare and represents taha hinengaro, taha tinana, taha wairua and taha whanau. 


\section{Te Māori exhibition}

This section examines the Te Mãori exhibition as an example that highlighted the relationship between museums and Māori and, by association, the mana and power of taonga in the Māori world. This case study extends our understanding of this relationship as it provided a watershed moment on museum-iwi relations. Te Mãori is included here because not to include it would be a glaring omission of its international and national significance with regard to Māori heritage and those who were largely in control of it. Te Māori follows on from the previous section on taonga Māori because it was during this time that a substantial corpus of writing on Māori taonga by Māori occurred.

The Te Mãori exhibition was a defining moment for museum-iwi relations as it was arguably the first real opportunity that Māori people had to manage and present their taonga or ancestral treasures held in museums, both nationally and internationally. Much has been written about the Te Măori exhibition that travelled to the United States in the 1980s and returned to New Zealand where it broke all records. ${ }^{83}$ Described as a turning point and a defining moment in our nation's history, the Te Māori exhibition challenged the stifling museum orthodoxy and re-awoke Māori to their ancestral treasures. The Te Māori exhibition was a defining moment for the museum sector as it questioned museum-iwi relationships and issues around interpretation, governance, power and control.

The Te Mãori exhibition highlighted the inadequacies of the museum community; the lack of access, of recognition, of acknowledgement. ${ }^{84}$ The exhibition challenged those who managed and controlled our taonga and in a highly visible way highlighted the inadequacies of museum-Māori relations. Te Mãori signalled a 'turning point'; no turning back, a time for museums to examine and change the way they do things, the way they operate. The profile of Māori art was raised on the international stage. Tapsell notes the role that Te Mãori played in the development of a bicultural nation, but also said that what was not apparent in museological discourse was the 'catalytic role of taonga'. 85

For the Minister of Māori Affairs Koro Wetere it was the people, both young and old, who gave life to the taonga in Te Māori:

83 See Butler, P. 1996. Te Māori Past and Present: Stories of Te Māori. MA, Massey University, Palmerston North.; McCarthy, 2007; Mead, 1984, 1986b; Obiso, 1987; Tapsell 2003.

84 Tapsell (2011) says that the Rotorua Museum is an exception in that Te Arawa were encouraged to store their taonga in that museum since the late 1960s (p.95).

85 Tapsell, 2011, 95. 
Te Māori showed the world of art and museum presentation that treasures like these are still part of our present and living culture. To the unknowing, the pieces by themselves are merely made of wood and stone, but when the elders with the young come together to chant the rituals of yesteryear, and to sing the songs that recount the history, the hopes, the hurts, and the aspirations of the people - the exhibition lives. The people are the living culture, and they breathe life into the taonga - and when the two come together the exhibition becomes a living and new experience for the uninitiated. ${ }^{86}$

The 1980s launched a major Māori art exhibition on to the world stage that was to bring in to focus issues pertaining to museums and Māori people and their tribal taonga. The Te Mãori exhibition that travelled to four prestigious museums in the United States in 1984-5 and then its homecoming tour or Te Hokinga Mai in four museums and art galleries back in New Zealand was a phenomenal success. To say that it had a profound transformational affect is a gross understatement. Described as a watershed moment in New Zealand's history the Te Māori exhibition travelled to some of the great art museums in the United States. ${ }^{87}$ The Te Māori exhibition opened dramatically at the Metropolitan Museum of Art in New York on $10^{\text {th }}$ September 1984 with a ritual dawn service that moved those who witnessed and experienced it. Exactly three years later, Te Māori closed at the Auckland City Art Gallery with deep celebrations and reflections of its journey. The Te Māori Te Hokinga Mai tour included four major venues in the North and South Islands. ${ }^{88}$

Te Māori was a great collaboration and cooperation between American museum personnel, the American Federation of Arts, the Arts Galleries and Museums Association of New Zealand, the Māori people of New Zealand, museum and gallery staff, the South Pacific and Queen Elizabeth Arts Council, and sponsors, such as Mobil Corporation and Air New Zealand. Te Māori beamed lived coverage back to New Zealand and included documentaries of its phenomenal success. For Kara Puketapu, Te Māori revitalised the people and made us think about our art, our culture and our people: "When we staged Te Māori art exhibition in the United States it reminded us that we had art! We were rushing on, no one was looking at

86 Wetere, Koro. 1986. "Comments on the Te Māori Exhibition”. Art Galleries and Museums Association of Aotearoa New Zealand no. 77 (3):6.

87 The Metropolitan Museum of Art in New York (September-November 1984), Saint Louis Art Museum, Saint Louis (February-May 1985), the de Young Memorial Museum, San Francisco (July-September 1985), and then to the Field Museum, Chicago (March-June 1986). The Field Museum was organized as an additional venue during the time that Te Māori was touring in America. Great interest was shown by the Field because of the fact that they had the largest collection of Māori taonga in American museums which also included the Ruatepupuke meeting house originally from Tokomaru Bay, East Coast of the North Island.

88 The National Museum, Wellington (August-October 1986), Otago Museum, Dunedin (November 1986February 1987), the Robert McDougall Art Gallery, Christchurch (March-May 1987) and the Auckland Art Gallery (June-September 1987). 
our museums and suddenly we unleashed a whole new dimension for our young people - to think about art, our culture and about themselves." 89

Te Māori was a watershed event for New Zealand in the 1980s and its sphere of influenced reached far and wide. Te Māori has been described as an effective site of resistance that took control of an international exhibition of Māori taonga and compared to another watershed event in Canada in the late 1980s, The Spirit Sings exhibition. The difference between the two is noted by Butts:

Both The Spirits Sings and Te Mãori (1984-87) were effective sites of indigenous resistance to museum practices and recognised as such by the museum profession worldwide. However, whereas The Spirit Sings became a symbol of the need for change, $T e$ Māori became symbolic of the extent to which Māori were able, in the mid-1980s, to grasp the initiative and control an international exhibition of taonga Māori from public museum collections, and to resist current museum practice. ${ }^{90}$

Te Māori was an emotional journey for many Māori as it was fort the assertion of Māori selfdetermination. Described as a voyage of rediscovery, it was a waka that carried the hopes and aspirations of Māori with respect to their cultural taonga, as Butts says:

Te Māori provided the vehicle for those who were advocating Māori control of their own heritage resources, including taonga Māori in museums, to promote their cause. ${ }^{91}$

Māori people were well involved in the planning and organisation of Te Māori and this extended to many of Māoridom's leaders, such as Te Atairangi Kaahu, Sir James Henare, Sir Hepi Te Heuheu and Sir Monita Delamere, notwithstanding the tribal tohunga, kapa haka leaders and academics and politicians. Arguably it was one of the first occasions where Māori were largely in control of the exhibition process, taking charge of the planning processes and tikanga, and working with museums, government agencies, universities and organisations in its delivery and execution. The rituals, oratory, tikanga (customs) and dawn ceremonies with the large presence of tribal elders were an important part of the indigenous category of display that recognized the objects as taonga as opposed to artefacts. ${ }^{92}$

The rituals and tikanga for the exhibition acknowledged the mauri or living life-force of the 174 Māori tribal taonga that accompanied the exhibition. The Māori classification from

\footnotetext{
Melbourne, 1995, 47.

Butts, 2003, 51.

Butts, 2003, 84 .

McCarthy, 2007, 135.
} 
artefact to taonga was to acknowledge the tapu dimensions, as well as to present the taonga as an integration of the visual arts with the performing and oral arts. ${ }^{93}$

A range of Te Mãori publications were associated with the exhibition, including an exhibition catalogue and education programme materials. Māori tribal groupings were formed to lead the opening ceremonies and associated events and kaiārahi or guides were selected. These guides were trained by June and Sid Mead and provided a unique cultural interpretive dimension quite different from that known in museum practice. As noted by the Auckland Art Gallery in their Te Māori exhibition anniversary display in 2007:

Interpreters increased the mana of taonga and by extension their ancestors, by providing a unique world-view. The mana of the exhibition and the emotional relationship to the taonga was reflected in the wholehearted commitment given by the elders, guides, educators, Māori Wardens and gallery staff. ${ }^{94}$

In the reclassification of significance from the stifling ethnographic gaze to that of mana Māori and taonga tuku iho, Māori effectively were reclaiming their mana motuhake and giving respect. As McCarthy notes, Rangihau said that for him it wasn't about the change from museum to gallery or artefact to art but rather 'from neglect to respect'. ${ }^{95}$ In many ways Rangihau, like Mead, saw the connection of taonga with tribal identity and pride when he said: "They represent living things for us as Māori, they have to be seen and not left in a corner, or down in the basements of the museums of New Zealand ... Here they are being displayed in a most artistic way, in a way that says something about the culture of the people who made them. It says: "We are here, we stand tall.,",96

The taonga in Te Māori was described by Mead as 'symbols of Identity' and he also believed that the answer to contemporary problems was to reinforce Māori identity. ${ }^{97}$ The exhibition swelled with Māori pride in their close association with their taonga. As an historical moment

93 Ibid. 139.

94 Gallery, Auckland Art. “Anniversary Display - Te Māori: Māori Art from New Zealand Collections Overview”. http://www.aucklandartgallery.com/whats-on/events/2007/june/anniversary-display-te-māoriMāori-art-from-new-zealand-collections. Accessed on 1/10/2011.

95 See McCarthy, 2007, 142.

96 Cited in McCarthy, 2007, 142. Original source is kaleidoscope documentary by Derek Fox.

97 Mead, Hirini Moko. 1990. "Tribal Art as Symbols of Identity". In Art and Identity in Oceania, edited by Alan Hanson and Louise Hanson, 269-281. Honolulu: University of Hawai'i. 
in time, the exhibition raised the mana of Māori art, revitalised Māori culture and drew the people of New Zealand closer together. ${ }^{98}$

Te Māori was one of those transformational moments in our nation's history. Te Mãori made a huge impact on organizations and people and its success rippled through the museum world, touching the lives of those who were involved and raising issues about taonga and the museums who house them. As noted before:

Te Māori was transformational and it awoke the spirit of our ancestors on distant shores and stirred the imagination and minds of those working in museums. Its influence and legacy has been profound. It changed the lives of people and museums, it involved our people in ways never before undertaken, and it said to the world here are our taonga and we are its people. ${ }^{99}$

Te Mãori introduced the notion of 'cultural ownership' where it was deemed critical that the appropriate tribes were consulted and liaised with regarding their taonga. Sid Mead and Kara Puketapu were adamant that this was a necessary process. Hamish Keith described the exhibition as something special and unique right from the start and that, with respect to cultural ownership, "it was agreed that regardless of the legal ownership or physical possession, no work could be included unless its spiritual owners - the people from whom it came - agreed." 100

In the catalogue of the Te Mãori exhibition catalogue, Mead wrote that the carvings on display in museums were taonga which were given life and meaning by 'kupu' or words. When Māori view and respond to these taonga, he said, they are animated by the 'korero', the talk or language which surrounds and 'clothes' them, gives them meaning and value for the people. $^{101}$

For Ngahiwi Tomoana, the Chairman of Ngāti Kahungunu Iwi Inc., the Te Māori exhibition was more than a static exhibition:

98 Gallery, Auckland Art. "Anniversary Display - Te Māori: Māori Art from New Zealand Collections Overview”. http://www.aucklandartgallery.com/whats-on/events/2007/june/anniversary-display-te-māoriMāori-art-from-new-zealand-collections. Accessed on 1/10/2011.

99 Hakiwai, Arapata, and Philipp Schorch. 2014. "Mana Taonga and the public sphere: A dialogue between Indigenous practice and western theory". International Journal of Cultural Studies no. 17 (2):191-205.

100 Kernot, B. 1987. "Te Māori Te Hokinga Mai: Some Reflections". AGMANZ 18(2): 3-4.

101 Mead, 1984, 21. 
Te Māori wasn't just about taonga it was about the people and the flesh that went with those taonga it was taking the us as a people to the world and the taonga was that ka moe. The ka puta was the relationships they were built up on, so it wasn't seen as a static art exhibition, this nice great culture from the antipodes it was a seen as a vibrant and explosive people culture. ${ }^{102}$

Mead says that there were many benchmarks associated with Te Māori, such as the opening ceremonies and the breakfast following the dawn ceremony, ${ }^{103}$ notwithstanding the cultural ownership dimension and the large Māori involvement. Te Māori also influenced museums and museum practice and for Butts there were five major changes with regard to taonga Māori that emerged during and following Te Māori namely:

1) Reconceptualized and revalued taonga not as ethnological curiosities but as taonga-tuku-iho

2) Acknowledged the link and connection between taonga and the people for whom they had significance

3) Exhibitions shifted from typological and static displays to a stronger focus on the nature and meaning of taonga-tuku-iho as part of a wider context

4) Māori participation moved away from donor/subject focus to participation at all levels

5) Significant growth in the number of Māori museum practitioners. ${ }^{104}$

Mead believes Māori culture has been distorted, squeezed and stretched to fit western-trained scholars and that there is a reaction against the monopoly of knowledge of Māori culture that is in the hands of Pākehā institutions. ${ }^{105}$ Mead was of the strong opinion that Māori needed to reclaim control and drive the bus and not be the passengers:

The Māori people want to control their own heritage; they want to be the people who handle their taonga; they want to have the knowledge to explain them to other cultures; they want to explain them to their own people; they want to define their past and present existence, they want to control their own knowledge (matauranga Māori) and they want to present themselves their way to the world and to themselves. ${ }^{106}$

102 Ngahiwi Tomoana interview, September 2011. Tomoana believed that the Te Mãori exhibition was one of three thunderous reverberations around the world, the first being the reputation of the Māori Battalion and the second the Māori All Blacks.

103 Diamond, Paul. 2003. A Fire In Your Belly: Māori Leaders Speak. Wellington: Huia Publishers.

104 Butts, 2003, 318. Butts adds that the Māori protocol for ceremonial openings became the accepted form for exhibitons of taonga-tuku-iho and contemporary Māori art exhibitions and that consultation between Māori and museums and the care and interpretation of taonga increased as a result of Te Māori (p.89).

105 Mead, Sidney.1997. Māori Art on the World Scene: Essays on Māori Art. Wellington: Ahua Design \& Illustration Ltd. 154.

106 Sid Mead, 1985. From a lecture titled 'Te Māori comes home: The Walter Auburn Memorial lecture' to the Friends of the Auckland City Art Gallery, July 31st 1985, 4. (Cited in the Victoria University Museum Studies MHST 515 Course Programme 2012, (p.5). 
It was an indictment that Māori taonga had to leave New Zealand for them to be better understood and appreciated in New Zealand. ${ }^{107}$ The decision to take taonga to some of the great art museums of the world was deliberate as was its recontextualization from its primitive art museum tradition, as Mead notes in the Te Mãori publication:

The Metropolitan is synonymous with international art. It is the centre of the world of art. By taking our art to New York, we altered its status and changed overnight the perception of it by people at home and abroad. We brought Māori art out of the closet, out from obscurity, out from anonymity, and out of the cupboard of primitive contextualisation. In fact, we rescued it and freed it from the limiting intellectual climate of New Zealand, releasing it so it could be seen by the world. ${ }^{108}$

For Mead the context is a critical dimension of Māori taonga and museums have not been good to Māori. The rituals and tikanga for the exhibition acknowledged the mauri of the 174 Māori tribal taonga that accompanied the exhibition. The Māori classification from artefact to taonga was to acknowledge the tapu dimensions as well as to present the taonga as an integration of the visual arts with the performing and oral arts. ${ }^{109}$ In a forthright and direct way, Mead used the words 'released', 'freed' and 'imprisoned' in association with the Te Mãori exhibition when describing Māori art and how this has been interpreted. Mead said:

\begin{abstract}
Māori art was transformed and in a sense "released" and "freed" from the history and intellectual context in which our artworks had been "imprisoned". I saw our art become art by destination and become accepted by the international community of art historians, curators, scholars, admirers and journalists. It was a different definition from that of ethnological museums and of the discipline of anthropology. It was achieved by changing the context of our art from that of natural history with its animals, fish, birds and insects to the Metropolitan in New York. Another was to take art out of a New Zealand context of misty obscurity and thrust it on to the world stage of international art. $^{110}$
\end{abstract}

The influence of Te Mäori is seen in the changing bicultural governance arrangements of some museums, the process of exhibition development, the recognition of mātauranga Māori and tikanga and how museums engage, consult and partner with Māori. The creation of Te Papa was directly influenced by Te Mãori, as were key museum policies including the Karanga Aotearoa Repatriation Programme, the Mana Taonga principle at Te Papa and the Museums Standards Scheme. Te Māori raised the profile of Māori art on an international and

\footnotetext{
107 This view was emphasized on the Koha Māori documentary in 1985 titled 'Te Māori Guard, New York 1985’ (http://www.nzonscreen.com/title/koha-te-Māori-Guard-New-York-1985).

108 Mead, 1986b.

109 Ibid. 139.

110 Mead, 1997, 153. This article was originally published in the AGMANZ Journal, Vol.16. No.3 pp.3-5, September 1985 but was substantially revised.
} 
national stage and with it a substantial corpus of writing. Our deep understanding of the nature and power of taonga Māori would not have happened had it not been for the Te Māori exhibition. For Geismar, Te Māori was "one of the first aesthetic platforms in the postwar period that empowered Māori people internationally and which promoted the idea of Māori museology."111

The following two small projects are highlighted because they help to contribute to the understanding on tribal taonga from the perspective of tribal members. They extend the nature of taonga to photographs of Whanganui ancestors and their importance to their descendants, as well as discussions involving Ngāi Tūhoe and their tribal taonga.

\section{Partington photographs}

The Whanganui iwi have two recent examples that illustrate the role that Whanganui tribal taonga play in the lives of the people. The first concerns the public auction of the Partington photographs of Whanganui people in 2001. ${ }^{112}$ A large collection of Partington photographs came up for auction at Webb's Specialist Auctioneers of Fine and Decorative Art in Auckland on $21^{\text {st }}$ September 2001. What followed was an intense appeal by Whanganui people to have these images returned back to Whanganui. The Whanganui people were only notified of the Webb's auction a week prior to the sale through the Whanganui Chronicle, although Webb's said that this was advertised nationally before that. Although other museums like Te Papa were interested in the Partington Collection, Te Papa withdrew after discussions they had with Whanganui iwi representatives who had a good working relationship with them through the Te Awa Tupua Whanganui Iwi exhibition at Te Papa. ${ }^{113}$

There were heated discussions and protests at the Webb's auction as many Whanganui people were infuriated that their tipuna or ancestors were being commodified and treated in this way. There was a lot of discussion and arrangement made by Webb's and interested buyers, as well as the owners of the collection. The sale was eventually halted and the Partington photographic collection was offered to the Whanganui Regional Museum for $\$ 135,000$ with

\footnotetext{
111 See Geismar, Haidy. 2013. Treasured Possessions: Indigenous Interventions into Cultural and Intellectual Property. Durham and London: Duke University Press. 97.

112 The William Henry Thomas Partington photographs included 560 photographs and 240 glass plate negatives (see Carroll, 2008).

113 See Carroll, 2008, 43-44. The Whanganui Iwi Exhibition was the fourth iwi exhibition at Te Papa since Te Papa opened in 1998.
} 
12 months to pay. ${ }^{114}$ Added to the growing discontent was the fact that Random House sold the publishing rights to the images on the morning prior to the collection going to auction. ${ }^{115}$ The right to produce the book was negotiated through Webb's between the owners and Random House. Those attending the auction, including the Whanganui Regional Museum, were not told about the contract prior to negotiating a purchase agreement. ${ }^{116}$

In early July 2002 the photographs returned home to Whanganui with over 200 people, including many of the descendants of the ancestors. ${ }^{117}$ What transpired after their return home or te hokinga mai were discussions about losing control over the use of the images. For Carroll "the value placed on these photographs by Māori comes from the heart and the mind" "18 and for many Whanganui people they represented real people, along with the history and whakapapa of their environment and identity. The feelings of Whanganui people regarding these taonga and what they meant to them was very evident.

For Māori, the photograph of an ancestor carries the mauri, wairua and mana of that person. $^{119}$

It is a different perspective of the world for some, but for us there is no doubt in our mind that these people are from the River and connected to us, our tūpuna. You just knew it. They reflect thousands of people who live today. ${ }^{120}$

Here were these tipuna that were seen by some people as saleable items, to make a quick buck... So it was in that context that we decided the Collection - our tūpuna - needed to be reunited with our people. ${ }^{121}$

What followed on from the acquisition of the Partington photographs was an exhibition titled Te Pihi Mata: The Sacred Eye that opened at the Whanganui Regional Museum on $7^{\text {th }}$ December 2007. This exhibition was opened by the co-leader of the Māori Party Tāriana Tūria and local kaumātua or elders. Tūria's comments are relevant for my research as they show the important place that Whanganui taonga like photographs play in the lives of Whanganui people:

We look with love on the face of Wì Pauro, te tohunga ahurewa; a spiritual leader whose legacy is still felt and remembered every year in our Tira Hoe Waka, our tribal journey in

\footnotetext{
114 Ibid. 54.

115 Ibid. 61-62, 122.

116 Ibid. 122.

117 This was reported in the Whanganui Chronicle, 22 July 2002. See Carroll, 2008, 65.

118 Carroll, 2008, 80.

119 Carroll, 2008, 1. (Ken Mair interview, $14^{\text {th }}$ December 2005).

${ }^{120}$ Ibid. 39. (Ken Mair interview, $14^{\text {th }}$ December 2005).

121 Ibid. 46.
} 
which we recount our whakapapa, our kōrero and our tikanga in the place and context where it belongs - within the River, for the river. ${ }^{122}$

We have suffered for too long the cruelty of window dressing approaches that attempt to give superficial recognition to our history, our customs and language - feeling as if, in the words of indigenous Vietnamese academic Trinh Minh-ha, we've been "captured, solidified and pinned to a butterfly board". ${ }^{123}$

The significance of cultural heritage to tribal identity is important for many Māori as noted by the deputy leader of the Māori Party Tāriana Tūria when she reminds us that our cultural heritage and taonga tuku iho reinforce our identity as tribal people and tangata whenua: "many of our taonga were kidnapped and that it's the living relationship that gives meaning and cultural value to taonga." 124 Tūria cites the well-known Whanganui proverb "Te Taura Whiri a Hinengakau' as an example that illustrates the inseparability of people and their culture. $^{125}$

\section{Ngāi Tūhoe Waitangi Tribunal claim}

In an inter-agency cultural workshop held for Archives New Zealand, the National Library of New Zealand and Te Papa Tongarewa with members of Ngāi Tūhoe working on their Letter of Commitment for the Ngāi Tūhoe Deed of Settlement, a number of statements were made by them that affirm the importance of Ngāi Tūhoe taonga to Ngāi Tūhoe people. The meeting was held at the Office of Treaty Settlements on $24^{\text {th }}$ October 2013and the Ngāi Tūhoe members included Tamati Kruger (Chairman) and Kirsti Luke (CEO) of Ngāi Tūhoe.

Tamati Kruger talked about the loss and uncertainty and the loss of power and influence of Ngāi Tūhoe with regard to their cultural heritage. For Kruger it was about the "restoration of our relationship with our taonga" and about restoring our connections and relationships with our taonga. In the inter-agency meeting Kruger recalled the words that one Ngāi Tūhoe elder had made when Mataatua kaumātua were invited to a meeting at Opotiki in the 1990s to discuss and give feedback on Te Papa's concept. Although all the Mataatua elders agreed, when it came time to vote this one kaumātua disagreed. He said: "It's a taonga when it's in

${ }^{122}$ Carroll, 2008, 75. Tariana Turia's opening speech for Te Pihi MataWhanganui Regional Museum in 2007 (see http://www.infonews.co.nz/news.cfm?l=1\&t=0\&id=10883).

${ }^{123}$ Ibid, 76. Tāriana Tūria's opening speech for Te Pihi MataWhanganui Regional Museum in 2007 (see http://www.infonews.co.nz/news.cfm?1=1\&t=0\&id=10883).

${ }^{124}$ Tāriana Tūria Government Press Release 2002 'Matariki, and Māori Cultural Heritage', $12^{\text {th }}$ June 2002.

${ }^{125}$ Ibid. Turia notes how she is a descendant of the Whanganui River and that the tribal proverb 'Te Taura whiri a Hinengakau' refers to the close intertwining of whakapapa, traditions and history of the many whānau and hapū up and down the river. 
my hands; it's a souvenir when it's in your hands". For this elder, taonga need to be returned to their people to activate the mauri otherwise they are just like a souvenir when they are away in a museum in other people's hands.

This chapter has shown the nature of the relationships between Māori and museums in New Zealand in order to provide a background context for the chapters that follow. In large part, museums have played a strong role in the colonisation process with museums guilty of perpetuating a western colonial mode of operating. In this context, Māori have largely been the passive observers looking from the outside in, although as McCarthy notes there has been a continuous engagement of Māori with the mainstream practices of collecting and display. The monocultural museum practice became glaringly obvious during the time of the Te Māori exhibition, being described as shabby and obsolete. ${ }^{126}$ Māori clearly want a stronger involvement in the business of museums and the post-bicultural museology of the 1990s will be looked at with interest in the near future as new spheres of influence appear within our nation state and as Māori take a stronger role in the planning of their cultural heritage future. $^{127}$

The chapter has shown how powerful Māori tribal taonga are to the people and wider culture. Taonga are treasures handed down through the generations to be cherished, recalled and remembered as if made yesterday. They are strong symbols and markers of Māori tribal identity, connecting the past with the present and future. Māori cultural heritage and taongatuku-iho, as Tāriana Tūria expresses it, help to reinforce our identity as Māori tribal people and as tangata whenua. They also carry the past into the future. Taonga are not relics of a past bygone age, but highly relevant and interconnected with the culture and the Mâori world in an age of modernity. An array of enduring relationships to taonga is a common feature shared by tribes, along with their contemporary importance for the present generations.

The power of tribal taonga, as many authorities have demonstrated, is best understood within tribes' own customary values and knowledge systems, with whakapapa and mana being two central principles. Whakapapa is a key Māori customary concept associated with taonga that

${ }^{126}$ Peter Tapsell was Minister of Internal Affairs at that time and made the comment in the AGMANZ Journal that "Te Māori has proved to us that a museum's interpretation of the 'culture' of a country needs to be something more than a lifeless collection of dusty artifacts."

127 O'Sullivan, Dominic. 2007. Beyond Biculturalism: The Politics of an Indigenous Minority. Wellington: Huia Publishers. O'Sullivan notes that biculturalism was a response to the growing Māori political assertiveness during the 1970s to ' 80 s and became a philosophical framework for policy development across the public sector. The development of the new National Museum was also influenced by this agenda with the bicultural principle being actively championed as a foundation for Māori participation and partnership. 
connects the past with the present, the ancestors to the descendants, taonga to myriad relationships. We see how taonga are connected to multi-dimensional relationships that are not time-bound but fluid and open. Tribal taonga express relationships at inter- and intratribal levels, and their association with the past and the ancestors provides the living connection from the past to the present. Other customary concepts that are important to an understanding of taonga are mana, tapu and kōrero. Tapsell also reminded us of the mauri or life-force of taonga and how this is protected through ritual and marae performances in their trajectories as comets and tui. Further to this, Tapsell noted how taonga are inseparably layered within a wider genealogical cloak of knowledge.

Mead and Tapsell reminded us that taonga have a wairua or spiritual dimension which makes them different from that of an artefact. The lives of the ancestors and their legacies, as represented by taonga, are strong symbols for iwi and hapū. This chapter also informs us that taonga are important in the lives of contemporary descendants for tribal identity, cultural renewal and revitalization. Taonga are also being actively used by tribes as conceptual symbols to help shape and inform future tribal development aspirations.

The Te Māori exhibition continues to be a touchstone of Māori cultural aspiration and selfdetermination. Te Māori was a defining moment in our nation's history showcasing Māori tribal treasures on an international stage. Te Māori recontextualized the exhibition process from an ethnographic gaze to a Māori cultural gaze where artefacts and objects became taonga and Māori art equal to any other great art traditions in the world. Te Mãori was about the Māori people and their culture and the place of the arts within it. The totality of the culture, including the karakia and rituals, waiata and whaikorero, was an important part of the 'cultural ownership' dimension. The exhibition had a profound influence on museum practice and governance, including the recognition of cultural knowledge, tikanga and protocols. The lessons learnt from Te Māori have helped transform the museum community and stimulated pride and self-determination for tribes embarking on planning their cultural futures. 


\section{Chapter Two: He Tino Rangatiratanga, He Mana Motuhake - Assertions of Sovereignty}

\section{Introduction}

Chapter One looked at the relationship between museums and Māori and examined the power of Māori tribal taonga and its interconnectedness with the culture and the Māori world. Chapter Two reviews the politics and assertions of sovereignty for indigenous and First Nation peoples and examines various instruments and policies in pursuit of sovereignty and self-determination. Following the overview of the international context, this section will then explore assertions of sovereignty by Māori and the pursuit of self-determination as the tangata whenua of Aotearoa New Zealand.

Within the context of self-determination, this chapter then examines the nature of Māori tribal development, canvassing the key periods that characterized Māori development since first arrival. This chapter examines the nature of that development through an analysis of Māori leaders, academics and Māori tribal lived realities. Key themes and threads along with similarities and differences are examined, as well as views of Māori development from iwi tribal leaders, artists and workers. Tribal development is being progressed largely through the Waitangi settlements process and tribes are planning their tribal futures with a view to balancing the need to grow their investments and provide for the wellbeing of their tribal people. This chapter looks at the nature of Māori development in contemporary times through the perspective of tribal visions, tribal leaders and leading academics.

\section{First Nation and indigenous peoples}

First Nation and indigenous peoples have long pursued sovereignty and self-determination. This struggle is largely in response to the legacy of colonization and western imperialism, where colonized people are often in a state of subjugation, exploitation and domination. ${ }^{1}$ As an example of imperialism, Smith mentions Christopher Columbus as a figure who has come

1 Hill (2004) notes that in the face of colonization by a coersively superior power "indigenes have struggled to retain as much of their own value systems, resources and socio-political organization as possible" (p.11). 
to represent a huge legacy of suffering and destruction. For the South Pacific, the explorer James Cook is given as example more close to home of the 'heroes' and 'fathers' of colonialism. $^{2}$

For some, self-determination is about taking charge and being in control of your own destiny and making decisions for yourself and for your people. Self-determination is strongly associated with other terms, such as self-management. For example, Mason Durie writes: "The challenge is to create a climate within which self-management becomes the norm, and self-determination becomes the goal... Self-management is a pre-requisite for selfdetermination, and self-determination is a precursor for wellness." 3

Colonization has had a traumatic effect for many cultures and its legacy is clearly seen in the area of health where dependency has replaced independency: "For indigenous peoples, dependency has been part of the post-colonisation experience" and Durie notes: "all too often, it has been aggravated by poor health." I have adopted the term 'First Nation' and 'indigenous peoples' for this section as a way of representing the 'other' whose voices and authorities are often suppressed or disregarded. I am also aware that these terms are problematic as there are other terms used to express the first peoples of the land. ${ }^{5}$ In this thesis I have chosen to adopt the appropriate terminology used by the people themselves.

Smith also reminds us that the struggle for self-determination often involves questions relating to the history of indigenous people and a critique of how we as the 'other' have been represented or excluded from the accounts. ${ }^{6}$ Given that colonization often involves the subjugation of indigenes and their histories and values, it is not surprising that the western view of history is given prominence, as Smith writes: "Under colonialism indigenous peoples have struggled against a Western view of history."7

As mentioned in the Introduction, objects and artefacts are an important element of culture, as are language, beliefs and customs. How indigenous people view their material culture is often different from how non-indigenous people view heritage, as Butts notes:

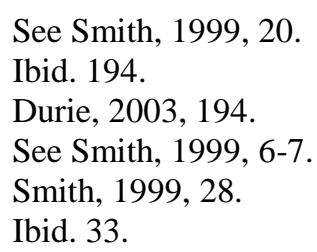


For aboriginal people, culture encompasses much more than the objects, but the objects cannot easily be separated from culture. It is more a case of which people belong to and with their particular culture, which includes the languages, beliefs and objects. In EuroCanadian terms, people own their 'heritage'. In aboriginal terms, the culture 'owns' the people. ${ }^{8}$

Indigenous resistance is an expression of self-determination and there are many examples that have highlighted tensions between museums and native people, such as the ongoing debate with regard to the Parthenon or Elgin Marbles in the British Museum and The Spirit Sings exhibition at the Glenbow Museum, Calgary, Alberta in 1988. ${ }^{9}$ This exhibition was highly controversial when the museum decided to hold a First Nation cultural treasures exhibition in conjunction with the Calgary Winter Olympics. Protests erupted between the Lubicon Lake Kree First Nation people and the exhibition organisers. The protest was a site of indigenous resistance, notwithstanding that a number of museums supported the boycott, including the International Council of Museums. ${ }^{10}$ What followed from this event was a major conference and The Turning the Page taskforce report that provided a foundation for partnership between First Nation peoples and museums. The Spirit Sings exhibition ${ }^{11}$ has been likened to the Te Māori exhibition in providing a watershed moment in Canada's history, as Butts says:

The case of The Spirit Sings has been discussed here because it was a watershed in the recognition of indigenous rights within the museum sector in Canada, in much the same way as the Te Mãori exhibition was a turning point in the relationships between Mäori and museums in New Zealand. The Spirit Sings became a point of reference, symbolic of a turning point in relationships between museums and First Nations. ${ }^{12}$

Butts in his research on museums and Māori identified three sites of indigenous resistance that led to significant change in the relationships between museums and indigenous peoples in North America and Australasia. These were international declarations and national policy statements, repatriation strategies and indigenous cultural centres. ${ }^{13}$

This is being backed up with international covenants, agreements and museum policies. In the literature there are innovative museum policies that help to address the concerns of

\footnotetext{
Butts, 2003, 55.

9 See Butts, 2003; Conaty, 2003, 2008; Barkan, E. 2002. “Amending Historical Injustices: The Restitution of Cultural Property. An Overview". In Claiming the Stones/Naming the Bones: Cultural Property and the Negotiation of National and Ethnic Identity, edited by E Barkan and R Bush. Getty Press.

10 See Butts, 2003, 47-51. Butts adds that the National Chief of the Assembly of First Nations (AFN) took the initiative to end the boycott when the exhibition closed at the Glenbow and opened at the Canadian Museum of Civilization in Ottawa (p.51).

11 See Phillips, 2011.

12 Butts, 2003, 54.

13 Ibid. 86.
} 
indigenous peoples. Self-determination is arguably about being in control of your own destiny and doing what is necessary for your own futures. Dominic O'Sullivan points out that "self-determination arises from a Māori political context, so its focus can be unmistakably Māori."14 Furthermore, "self-determination", he argues, "extends beyond human rights to rights of indigeneity. It asserts the right to a collective identity and, again to the greatest extent possible, the determination of cultural, social, and economic destiny." 15

An important feature of indigenous and First Nation peoples is the emphasis placed on the future dimension. This futures development relationship is based on a close relationship with the past and the ancestors and events that helped shape it. This is expressed by writers such as Jeffrey Sissons when he says that the recognition of indigeneity is and always has been about the future. ${ }^{16}$ This cultural future dimension is well supported by international instruments such as UNESCO, the Draft Declaration for the Rights for Indigenous Peoples and ICOM.

The United Nations Draft Declaration on the Rights of Indigenous Peoples (1993) also recognizes the right of indigenous peoples to cultural self-determination and their cultural property and the right to full ownership of their cultural property (article 29). Regarding Cultural Identity article 12 states that:

Indigenous peoples have the right to practise and revitalise their cultural traditions and customs. This right includes the right to maintain, protect and develop the past, present and future manifestations of their cultures ... as well as the right to restitution of cultural, intellectual, religious and spiritual property taken without their free and informed consent or in violation of their laws, traditions and customs.

The Declaration on the Rights of Indigenous Peoples is an instrument that recognizes the importance of culture and identity not in a past historic sense, but rather in a present and future state. Clearly, it speaks about the ongoing significance of maintaining, developing and growing. There is also a growing indigenous people's movement with respect to their cultural heritage. First Nation and indigenous peoples are embarking on a wide range of projects that are aimed at building their self-determining futures and wellbeing. The importance of

O'Sullivan, 2007.

Ibid. 5.

16 Sissons, 2005, 140. 
material culture to many indigenous people is clearly seen throughout the world and in more recent times extending to innovative digital repatriation projects. ${ }^{17}$

The First Nation artist and academic Richard Hill noted the future aspirational role that museums can play and argues that museums should consider new kinds of partnerships and relationships, and that museums can help ensure that cultural and religious beliefs continue and play an important role in the Native American future. ${ }^{18}$ Cultural regeneration and revitalization within a futures and developmental frame is a key theme of my research, as opposed to seeing heritage as stuck in the past. This view is strongly advanced by Simpson when she says:

For many Indigenous peoples seeking that spiritual independence, the protection and preservation of cultural heritage is closely tied to Indigenous education, sovereignty, language renewal, cultural revitalization, intellectual property rights, land rights, and health and well-being. Combined with these processes of cultural renewal and indigenisation is a shift from seeing heritage as evidence of the past, valued for its historical research and as the basis for a thriving heritage industry to recognition of the contemporary value of objects for living cultures. ${ }^{19}$

There have been numerous writers who have analyzed museums from an indigenous perspective over the last 20 years. ${ }^{20}$ Moira Simpson has examined the increasing number of museums and cultural centres that have been established by indigenous and immigrant communities as they take control of their cultural heritage. Simpson looked at the way western museums have reacted to this phenomenon and she challenged the traditional role of museums. ${ }^{21}$ The establishment of cultural centres and tribal museums is not new, as in the South Pacific there are good examples that incorporate the present and future in the display of culture. ${ }^{22}$ Key themes like indigenous curatorship, management and self-determination are

17 Examples include 'Recalling Ancestral Voices' (Sámi Cultural heritage) and the 'Reciprocal Research Network Research Project'. The Sámi people are the indigenous people of the European Union in the Nordic countries of Norway and Sweden. The goal of the 'Recalling Ancestral Voices' project was to repatriate knowledge of the material culture heritage to the Sámi in the form of a database. The Reciprocal Research Network (RRN) is a key component of the Museum of Anthropology's Renewal Project, 'A Partnership of Peoples'. It is being co-developed by the Musqueam Indian Band, the Stó:lō Nation/Tribal Council, the U'mista Cultural Society and the Museum of Anthropology.

18 Hill, 2007, 322.

19 Simpson, Moira G.. 2007. "Charting the boundaries: Indigenous models and parallel practices in the development of the post-museums". In Museum Revolutions: How Museums Change and Are Changed, edited by S.J. Knell, S. MacLeod and Sheila Watson, 235-249. London New York: Routledge.

20 Mead, Sidney (Hirini) Moko. 1983. “Indigenous Models of Museums in Oceania”. Museum no. 35 (139):98101.;Simpson, 1996; Stanley, 2007.

21 Simpson, 1996.

22 Stanley, 2007. 
important considerations for First Nation and indigenous peoples as they provide pathways on which indigenous people can further express their identity and development aspirations.

The establishment of cultural centres and tribal museums is not new and Stanley reminds us of the importance of living cultures in the South Pacific. ${ }^{23}$ Stanley looks to the future of museum practice through examining how these museums have evolved to incorporate the present and the future in the display of culture. Stanley introduced key themes like indigenous curatorship, management and self-determination within this discourse. Butts also reminds us that cultural centres are one element within the strategy of self-determination:

Within an indigenous community a cultural centre can provide a focus for cultural renaissance. This may take the form of creating collections of cultural treasures, archives, photographs and contemporary artworks, language recovery programmes, and performing arts programmes. Cultural centres also provide a contact zone where indigenous communities can communicate on their own terms with the wider society. The main difference between the cultural centre and the mainstream museum is that the cultural centre provides a forum in which the indigenous community can be selfdefining; the cultural centre becomes one element in a strategy of self-determination. ${ }^{24}$

\section{Assertions of Māori sovereignty}

Māori sovereignty means different things for different people. For Wira Gardiner, Māori sovereignty in its purest form is "the desire by Māori to have supreme control over their lives, their assets and resources, and to determine themselves where they may wish to go." 25 Richard Hill notes that rangatiratanga has been used in many ways from chieftainship, selfdetermination, mana Māori motuhake, governance and self-management, to name a few, through to autonomy. He says that the core of the collective aspiration is to "manage its own affairs, members and possessions.",26

Sid Mead believes that we must take the principle of self-determination and create something that specifically meets our own needs and aspirations: "Self-determination is a principle that cannot be denied. Tribal groups need to design and run their own cultural centers which

23 Stanley, 2007. See also Watt, L. 2005. “American Indian Tribes and their Museums”. Te Ara: Journal of Museums Aotearoa no. 30 (1):10-13. who has researched American Indian tribes and their museums.

24 Butts, 2003, 82.

25 Melbourne, 1995, 81. Gardiner noted the 1984 Hui Taumata (Māori Economic Development Conference) and noted that Māori speakers at the hui said, "We want control of our destinies, we want to control our own resources and we want to determine our own futures using our own resources" (p.81).

26 Hill, 2004, 13. 
specifically meet their heritage and educational needs. They must address themselves with vigour to a presentation of their own view of truth and history.",27

Over the last 25 years, Professor Mason Durie has written about the politics of Māori selfdetermination, health, cultural identity and Māori development, including providing schemas for best practice and futures development frameworks and forecasting. His involvement in this area has been both extensive and continuous. It is important that Māori want their own self-determining futures and that the aspirations for self-determination are intimately bound and connected to contemporary Māori life. As Durie notes:

Rather the aims of self-determination are practical and intimately bound to the aspirations and hopes within which contemporary Māori live. Essentially Māori selfdetermination is about the advancement of Māori people, and the protection of the environment for future generations. ${ }^{28}$

Durie has published extensively in the area of Māori health and in no significant measure contributed significantly to the literature on Māori self-determination and development. ${ }^{29}$ His research work in these areas has provided much-needed insights and directions and his models continue to be relevant frameworks and schemas for best practice and future directions. The Declaration of Independence in 1835 and the Treaty of Waitangi in 1840 have been described as assertions of rangatiratanga (chieftainship). ${ }^{30}$

Māori people have a long record of advancing initiatives towards a better self-determined future and challenging the Crown with respect to the Treaty of Waitangi. The struggle for self-determination has taken many forms and operated on a number of fronts and arguably these have all had a development focus in one form or another. Tania Ka'ai in her chapter on indigenous assertions of sovereignty says that Māori assertion of sovereignty has been expressed for at least 160 years and that this has taken many forms, including submissions, petitions, mounting deputations, occupying disputed land, the establishment of movements, marches, protests, boycotts and pickets. A long list of events, media, political movements, people, educational initiatives and churches are identified by Ka' ${ }^{2}{ }^{31}$

Mead, 1997, 155.

Durie, 1998, 4.

29 See Durie, Mason. 1993. "Māori and the State: Professional and Ethical Implications for a Bicultural Public Service". Paper read at Proceedings of the Public Service Senior Management Conference, Wellington., 1998, 1999, 2009a, 2009b.

30 O'Sullivan, 2007, 12.

31 Ka'ai, Tania M, John C Moorfield, Michael P J Reilly, and Sharon Mosley. 2004. Ki te Whaiao: An Introduction to Māori Culture and Society. Auckland: Pearson Lomgman. 181-182. 
Some of the Māori assertions of sovereignty noted by Ka'ai included: religious movements, such as the Pai Marire, Ringatū and Ratana faiths; political movements, including the Kīngitanga (1858), Kotahitanga (1892) and Nga Tama Toa (1970); and major events, including Parihaka (1869-1907), Māori Land March (1975), Occupation of Bastion Point (1977) and the occupations of Moutoa gardens in Whanganui in 1995 and 2002. ${ }^{32}$ Māori resistance is an important dimension in the quest for self-determination and Māori have had a long involvement in it. In comparing the journey of American Indians with regard to their resistance and protests over land and their lives, Kersey writes: "If American Indians had no voice to protest the outrages committed against their lands and lives, the Māori never shut up - it was just that Pakeha paid no attention." 33

Contemporary Māori sovereignty in the 1950s to 1970s found expressions in many forms. Orange attributed the Māori renaissance to the iwi-based War Effort Organisation and the success of the Māori Battalion in World War II, ${ }^{34}$ while the Māori Land March in 1975, including the occupation of Bastion Point and the establishment of the Waitangi Tribunal, were other expressions. ${ }^{35}$ The major projects that were initiated in the 1970 s by the Department of Māori Affairs under the leadership of Kara Puketapu were aimed at selfdetermination and self-reliance. Schemes such as Tu Tangata and the Kohanga Reo Movement, Matua Whangai, as well as the Te Māori exhibition, were about Māori being in control of their own future and destiny. McCarthy described this situation where "The Māoriled do-it-yourself ethos marked a profound shift in public policy away from assimilation and integration and towards self-determination." 36 However, there is a concern that in the pursuit of self-determination the cultural dimension might be left to the side at the expense of commerce and other political issues. As Puketapu points out, "It's no use talking about tino Rangatiratanga unless you end up equally rich in your culture. E ki ai koe he Māori." ${ }^{37}$ Puketapu is worried that the new emphasis on political issues will overshadow the language and culture and what it means to be Māori. ${ }^{38}$

Museums have become sites of resistance and struggle in their quest for recognition and the assertion of cultural identity. The 'politics of indigeneity' are being manifested in many

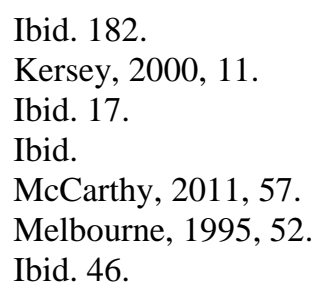


inward and outward ways and Māori sovereignty or tino rangatiratanga is being asserted to address grievances for land alienation and cultural redress in the Waitangi Tribunal. These expressions of cultural expression and vitality have meant that museums remain high in the sights of Māori people. As Butts notes:

As indigenous peoples negotiate new relationships with museums in the late twentieth and early twenty-first centuries they are doing so within the wider context of their pursuit of self-determination: they are reclaiming not only control of their material heritage held by museums but the right and responsibility of self-definition. ${ }^{39}$

The Mataatua Declaration is another instrument of Māori self-determination and assertion as it is of indigenous peoples' rights to self-determination. The Mataatua Declaration is a document that was borne out of a conference held in Whakatāne in June 1993 to discuss issues of the cultural and intellectual property of indigenous peoples. The conference was held as part of the celebrations of the United Nations Year of Indigenous Peoples and was attended by over 150 delegates from 14 countries with indigenous peoples from countries such as Japan, United States, India, Panama and the Pacific. Mead noted that the meeting was called to discuss and look at ways of protecting the 'treasures of the ancestors'. ${ }^{40}$ What is important about the Mataatua Declaration is that it is declared that indigenous peoples of the world have the right to self-determination and in exercizing that right must be recognized as the exclusive owners of their cultural and intellectual property. Other principles included:

- Define for themselves their own intellectual and cultural property.

- Develop and maintain their traditional practices and sanctions for the protection, preservation and revitalization of their traditional intellectual and cultural properties.

\section{Māori identity}

The importance of Māori identity is reinforced by many Māori, but Manaia believes that Apirana Ngata's famous kupu kōrero was encouraging youth to seek out knowledge derived from science and technology and blend it with Māori customary knowledge. ${ }^{41}$ Ngata's prophetic words are worth restating today, as they still retain significance and meaning in today's world with respect to both identity and development:

Butts, 2003, 43.

40 Mead, 1995, 69-71.

41 Manaia, W. and D. Hona. 2005. The Changing Face of Māori Development: Mauri Kaiarahi: Māori Leadership Values. Publisher? 7. 
E tipu e rea, mo nga ra o tou ao, ko to ringa ki nga rakau a te Pakeha hei ara mo to tinana: ko to ngakau ki nga taonga a o tipuna Māori hei tikitiki mo to mahuna: ko to wairua ki te Atua nana nei nga mea katoa.

Grow up and thrive for the days destined to you.

Your hands to the tools of the Pakeha to provide physical sustenance.

Your heart to the treasures of your ancestors as a diadem for your brow.

Your soul to God to whom all things belong. ${ }^{42}$

What is important in Manaia's thinking is that he believed Ngata was implying that a Māori identity was derived from the past and that this would be a stabilizing force in a rapidly changing world of change and uncertainty. ${ }^{43}$ Māori identity is a vital dimension associated with the Waitangi Treaty claims process and a report undertaken by the Law Commission in 2002 identified tribal identity as one of the defining considerations. The report cited Mason Durie's writing on modern Māori governance structures that warned against creating economically orientated organisations that fail to capture the essential cultural basis of the tribe. ${ }^{44}$ The report noted that "any new settlement model must support, and not be to the detriment of, tribal identity" and that this can be avoided by "creating a framework that recognizes the importance of tikanga Māori." ${ }^{\text {45 }}$

This view is shared by Te Awekotuku in a report presented as evidence to the Waitangi Tribunal in 2003 titled Nga Taonga o Te Urewera. Here, Te Awekotuku emphasizes the importance of place and people and the uniqueness of the Ngāi Tūhoe concept of matemateaone. According to Te Awekotuku, Te Urewera and Tūhoe are synonymous and that a strong sense of being Tūhoe is their very deep relationship with Te Urewera:

We still develop, retain and transfer to our children the vitalness of being Tuhoe, of belonging to Te Urewera. Te Urewera provides the setting for the development of models of our future Tuhoe selves. Te Urewera, as an environment in which we were raised, the objects within and emerging from it, and the events and experiences we are a part of act as psychic anchors, reminding us of where we come from, and provide a symbolic lifeline to a continuous sense of identity. ${ }^{46}$

42 The late Apirana Ngata in his famous words written for Rangi Bennett's autograph book on $10^{\text {th }}$ November 1949 made a plea for Māori to retain the treasures of their ancestors yet take full advantage of what the Pakeha world had to offer. For Ngata the future development of Māori was about retaining their cultural identity and taking advantage of what was being offered from all cultures.

43 Ibid.

44 See Treaty of Waitangi Claims: Adressing the Post-Settlement Phase: NZLC SP 13, p.2. See also Durie 1998a: 226-227.

45 Ibid.

46 See Te Awekotuku and Nikora, 2003. 
Ngāi Tūhoe tribal identity has a strong relationship with their land as enshrined within the Tūhoe cultural term of matemateaone. Te Awekotuku reminds us of this when citing John Rangihau:

This concept of the land is a central aspect of our personal and cultural identity ... We emphasise the question of land retention because we believe that the young of the future will need to have some base upon which they can stand - this sense of turangawaewae will be basic to their identity as Māori - as Tuhoe. If we, the people of this generation, allow our lands to pass to strangers then we are depriving our future young people of the chance to stand tall as Māori - on ground which they can regard as their Own. ${ }^{47}$

Te Awekotuku writes about the concept of 'place' and its importance with respect to Ngāi Tūhoe and supports Holloway's writing regarding relationality and how people make places as much as places make people. ${ }^{48}$ What are important to Ngāi Tūhoe are those anchors and symbols that provide a continuous identity along with the resilience of Tūhoe to maintain, develop and transfer the vitality of Ngāi Tūhoetanga:

The development of place identity begins in the earliest process of child socialization. The important point to note here is the amazing resilience of Tuhoe. We still develop, retain and transfer to our children the vitalness of being Tuhoe, of belonging to Te Urewera. Te Urewera provides the setting for the development of models of our future Tuhoe selves. Te Urewera, as an environment in which we were raised, the objects within and emerging from it, and the events and experiences we are a part of act as psychic anchors, reminding us of where we come from, and provide a symbolic lifeline to a continuous sense of identity. ${ }^{49}$

For Packer, Rankin and Hansteen-Izora the context of its locale is vitally important for the people: "culture as a legacy originates in locale, because it needs context in which to thrive: the context of the people and land that shaped it. While culture might be exported, without this context it will decay." ${ }^{50}$ Kirsti Luke, another Ngāi Tūhoe negotiator, reaffirmed the importance of Ngāi Tūhoe cultural heritage by describing "heritage" as "a day to day future tool." She articulated her position within Ngāi Tūhoe, saying that she was responsible for Ngāi Tūhoe cultural heritage and to that she added that her office was called 'the office of futures'. The other member assisting Ngāi Tūhoe and a former Supreme Court judge said the

47 Ibid. 25.

48 Ibid. 11. See L Holloway and P Hubbard, People and Place: The Extraordinary Geographies of Everyday Life Essex, England: Prentice Hall, 2001.

49 Te Awekotuku and Nikora, 2003, 16.

50 Packer, Laura, Paul Rankin, and Robin Hansteen-Izora. 2007. "Empowering Narratives for Minority Cultures". AEN Journal no. 2 (1). 38. 
following in relation to repatriation: "The moral argument for restitution is countered by the moral argument for restoration."

As the literature review on Māori identity noted, there are many dimensions associated with a Māori identity. As noted by Poata-Smith:

The shifting nature of identity means that individual Māori can and do represent themselves differently throughout the course of their lives, depending on the time, place and context, the audience, and the purpose of the occasion. Yet the Treaty settlement process has entrenched a view of Māori identity that draws on a mythic sense of primordial authenticity and a set of static cultural, social and political assumptions that ignore the dynamism and diversity of contemporary Māori society. ${ }^{52}$

\section{Māori development}

The well-known proverb by Apirana Ngata that is cited earlier in this chapter is widely known and often cited in Māori media and literature that focus on Māori identity and Māori development. These words were penciled by the great Ngāti Porou leader Apirana Ngata for Rangi Bennett's autograph book in $1949 .{ }^{53}$ Ngata made a plea for Māori to retain the treasures of their ancestors, yet take full advantage of what the Pākehā world had to offer. For Ngata, the future development of Māori was about retaining their cultural identity and taking advantage of what was being offered from all cultures. This proverb includes the key foundations of Māori development as conceived by Ngata in the late 1940s. Ngata was a prolific writer on Māori tribal development and was associated with many literary organisations.

Ngata believed that Māori development included holding on to and strengthening the culture and identity of the people as alluded to as nga taonga a o tipuna Māori or the treasures of the ancestors. His involvement in the ethnological fieldtrips (1919-1923), the establishment of the Māori Purposes Fund Board (1923), the active involvement in the affairs of the Polynesian Society, the establishment of the Māori Arts and Crafts Institute in Rotorua (1926), notwithstanding the building of at least 28 Māori tribal meeting houses ${ }^{54}$ and the compilation of traditional Māori waiata, attest to his philosophy and deep conviction that culture lies at the heart of Māori development. For Ngata, the future development of Māori

\footnotetext{
51 Meeting held at the Office of Treaty Settlements with Te Papa to discuss Treat claims on $24^{\text {th }}$ October 2013.

52 Poata-Smith, E.S. Te Ahu. 2004. "The Changing Contours of Māori Identity and the Treaty Settlement Process". In The Waitangi Tribunal: Te Ropu Whakamana i te Tiriti o Waitangi, edited by Janine Hayward and Nicola Wheen, R. Wellington: Bridget William Books. 23.

53 Evatt, B. 2010. Māori Enterprise and the New Zealand Capital Markets: Scoping Report, Te Puni Kokiri.

54 Henare, 2007c, 101.
} 
was about retaining the cultural identity and taking advantage of what was being offered from all cultures as alluded to as the nga rakau o te Pakeha. For Manaia, the modern concept of Māori development stresses notions of economic self-sufficiency, social equity, cultural affirmation and a greater measure of Māori authority. ${ }^{55}$ In more recent times, the Ngāti Porou tribal organization Te Rūnanga o Ngāti Porou has adopted these two key phrases to describe the ahi kā (those that remain at home looking after the lands, marae, tikanga, taonga and reo) and Ngāti Porou kei te whenua (those who seek to make their way in the world). ${ }^{56}$

Māori tribal development is growing exponentially when one considers the settlements of the Waitangi Tribunal claims. Māori tribes are embarking on development initiatives to better the lives of their people and to build a sustainable foundation. One merely has to look at Māori tribal websites and vision statements to see the language of development scattered throughout them. Also noticeable is how the development ethos extends to all areas of economics, including social and cultural dimensions. Development has many manifestations and in this chapter you will see a continuous pattern of development from the time of the early ancestors who voyaged to Aotearoa through to today.

Māori tribal development is a manifestation of self-determination and the ability of tribes to manage their own affairs and control their own destinies. A report on Māori economic development in 2003 noted how a large part of the discourse on Māori development promotes self-determination (or self-governance) as the desirable end goal. The report also noted Mason Durie's thoughts on what Māori self-determination is:

Māori self-determination is not primarily about a divided country or two nation-states, or the rejection of other cultures. Fundamentally, it is about the realization of collective Māori aspirations. And despite the many faces of contemporary Māori society, there is nonetheless a high level agreement that the central goal of tino Rangatiratanga is for Māori to govern and enjoy their own resources and to participate fully in the life of the country. Māori want to advance, as Māori, and as citizens of the world.

Tribes like Ngāi Tahu and Tainui have settled their Waitangi Tribunal claims and built strong economic pathways, yet never abandoned the cultural foundation on which their tribes rest. Certainly they would agree with Durie's philosophy when he says: "Māori self-determination is a shallow goal if a Māori identity is not part of the equation.",57

\footnotetext{
Manaia, 2005, 2.

See Te Rūnanga o Ngāti Porou website and the section on the history of Ngāti Porou.

Durie, 1998, 79.
} 
Māori development is much publicized and there is a burgeoning corpus of literature emerging on the politics of Māori development. Māori development, or more specifically Māori tribal development, has been undertaken for over 150 years and this has taken many forms and directions. Māori tribal development is not seen as a one-dimensional economic pathway, but rather an holistic development pathway that includes social and cultural dimensions based on our ability to express ourselves as Māori. Māori development often has a characteristic look and feel to it that incorporates Māori cultural values and concepts. Ngatata Love, a well-known Māori leader, reminds us of development and its relationship to its culture:

Development should seek not to compromise what it means to be Māori. Whether you are strongly tribal or urban-based Māori, development should enhance the ability of Māori to exercise choice and express our culture. No matter what the current national and international environment is like, Māori development must be based on our ability to express ourselves in ways which we feel, as a group and as individuals, are appropriate for Māori. ${ }^{58}$

Māori have been in development mode since first arriving to the shores of Aotearoa some 900 years ago. In the early contact period, Māori were involved in gift exchanges and trading with the new immigrants, supplying them with food supplies and trading flax and wood for the valuable commodities of guns and metal. This commercial endeavour soon led to Māori owning boats and schooners and, in the nineteenth century, trading produce in urban markets in Aotearoa and abroad. ${ }^{59}$ Since the arrival of Captain James Cook, there have been many benefits associated with European technology and many of these were taken up. However, as the anthropologist Raymond Firth noted, the eagerness to acquire these European benefits was not at the expense of compromising or surrendering Māori social institutions, core values and distinct way of life. ${ }^{60}$

As an example of the development ethos, it is said that "within 30 years of the arrival of the plough, Māori had moved from subsistence gardening to successful commercial farming.,"61 The 1840s to 1860s are described as the golden age of Māori enterprise where Māori owned

58 Love, Ngatata. 1998. "Māori Development: The Role of Te Puni Kokiri and the Link to Research". Paper read at Te Oru Rangahau: Māori Research and Development, at Massey University, Palmerston North.

59 Tribes from the Bay of Islands, Hauraki, Bay of Plenty, East Coast and Poverty Bay owned vessels. In 1858 in the Auckland Province, 51 ships were registered and 36 vessels licensed to Māori. (See Te Ara: The Encyclopedia of New Zealand 'Te Māori i te ohanga - Māori in the economy - Māori enterprise, 1840 to $1860^{\prime}$ (p.3)).

60 Carter, Lynette, Rawinia Kamau, and Mereana Barrett. 2011. "Te Pae Tawhiti Māori Economic Development Programme Literature Review and Programme Report”. Nga Pae o te Maramatanga The University of Auckland: Norcross. (p.11).

61 Ibid. 
flour mills and were the key suppliers of agricultural produce like wheat and potatoes to the emerging towns. This also included exporting produce to Sydney and abroad. ${ }^{62}$ As noted in the Te Pae Tawhiti Māori Economic Development Report:

In Auckland a daily sight was the large number of Māori canoes, laden with vegetables, pulled up on the beaches. In Taranaki they exported food direct to Melbourne to feed gold-diggers. Māori bought their own schooners and carried out their own coastal trade, and these Māori commissioned schooners were the basis of the local shipbuilding industry. ${ }^{63}$

Wira Gardiner reminds us that last century we were exporters, entrepreneurs, ship builders and ship owners with thousands of acres under cultivation. He says: "There is nothing in the future that we haven't done in the past." 64

Some writers have characterized the phases of Māori development and the nature of that development since the arrival of the ancestral voyaging waka. Edwards, for example, outlined five phases of Māori development detailing key themes, patterns and directions:

1. Pre-1900: Adaption for Survival

2. 1900-1950: Re-emerging Māori Leadership

3. 1950-1975: Urbanisation and Protest

4. 1976-2000: Treaty of Waitangi claims (language revitalization, eliminating disparities, codifying Māori development)

5. 2001-present: Continued focus on disparities, the globalized knowledge society, environmental degradation and resource depletion. ${ }^{65}$

Edwards says that Māori development was an ongoing process from pre-1900 through to modern times and that the arrival of the early voyaging waka from Hawaiki to Aotearoa New

62 See Te Ara: The Encyclopedia of New Zealand 'Te Māori i te ohanga - Māori in the economy - Māori enterprise, 1840 to $1860^{\prime}$ (p.3).

63 Carter, et al, 2011.

64 Melbourne, 1995, 89. Gardiner also notes that "In 10 years time we'll look back and ask ourselves why we didn't do it before? Why didn't we unleash all this energy before?"

65 Edwards, 2010. 
Zealand, and the adaptation to a colder and harsher climate was about development. ${ }^{66}$

Survival during these times called for the building of social and political relationships and adaptation to a new and vastly different climate and environment. The Waitangi Tribunal Wai262 Report (2012) noted that new technologies were required to cultivate, hunt and gather food and that over a period of hundreds of years "Hawaikian culture became a Māori culture." ${ }^{67}$ The early European colonization provided challenges and opportunities, as did the emergence of new leaders, such as Apirana Ngata, Maui Pomare and Te Rangihiroa in the period between 1900 and 1950.

Ngata was an ardent believer in holding on to and strengthening the culture and identity of the people, as these were vital pillars for the development of his people. This is perhaps no better illustrated than by the words he penned for Rangi Bennett's autograph book on $10^{\text {th }}$ November 1949. Ngata's plea was for Māori to retain the treasures of their ancestors, yet take full advantage of what the Pākehā world had to offer. For Ngata, the future development of Māori was about retaining their cultural identity and taking advantage of what was being offered from all cultures. For Iritana Tawhiwhirangi, Ngata was of immense influence and his words were: "the bicultural statement of all time. Your culture is A1, but there's another corollary to that in terms of your development, that is to go after the skills of the Pākehā. But, he didn't say go after that at the expense of your own culture." 68

Ngata had a profound influence on Māori development and throughout his career strove to ameliorate the conditions of the Māori race. Well before Ngata wrote those prophetic words for Rangi Bennett in 1949, he knew all too well the value of culture for his people. This can be seen in Ngata's invitation to the reception of the refurbishment of the Porourangi meeting house in March 1909: "Ki te mau i nga rakau a ngā tīpuna hei peruperu whakamutunga ki raro o Pūpūta' (To bear the heirlooms of the ancestors, in a finale of song and dance under Pūputa)., 69

Along with fellow old boys of Te Aute College, such as Te Raumoa Balneavis and Peter Buck, Ngata and Maui Pomare strove to "uplift the Māori people from the breakdown of their

66 Davis (2006) reminds us that the early ancestors had a deep sense of wairuatanga (spiritual belief system) and that it took a well-coordinated approach to ready the voyaging waka for their journeys. As Davis notes: "oral traditions indicate that the kākano who came from the east to Aotearoa were spirit-led, fulfilling ancient prophecies to pursue a distant land as a place of permanence for generations to come" (p.56). Waitangi Tribunal Wai262 Report $(2011,15,33)$.

68 Diamond, 2003, 106.

69 Walker, Ranginui. 2001. Tipua: The Life and Times of Sir Apirana Ngata. Auckland: Penguin Books. 213. This was described as a clarion call marking the cultural revival. (Original cited in King, M., Te Puea, p.81.) 
culture by colonization." ${ }^{, 70}$ Ngata saw land development by Māori as the best way to safeguard against alienation and he saw cultural revival as an important pillar for Māori tribal development. ${ }^{71}$ Ngata saw the power of arts and culture in uplifting the spirit of the people and, because of the decline in Māori art, "TACSA identified the teaching of carving and tukutuku weaving as central to the preservation of Māori culture and identity." ${ }^{, 72}$ Walker says that the paradigm for the recovery of Māori art and culture was impressed on Ngata at a young age when he attended the opening of the Porourangi meeting house at Waiomatatini in $1888 .^{73}$ Kersey asserts that "by the end of the century the main strategy for revitalising Māori culture was to work within the Pakeha system and manipulate it to Māori advantage" and that the Young Māori Party characterized this. ${ }^{74}$

In phase four, Edwards discusses the establishment of the Waitangi Tribunal, the Treaty of Waitangi claims, and some of the key initiatives that emerged during that time, including the establishment of the kohanga reo (Māori language nests), the Māori Language Commission, kura kaupapa Māori (Māori immersion schools) and wānanga (Māori tertiary institutions). Like other commentators, Edwards notes the codification of modern Māori development with the Hui Taumata (Māori Economic Summit) in 1984, which foreshadowed the decade of Māori development from 1984 to $1994 .^{75}$

Following on from that Hui Taumata in 1984, we see a number of major events that considered Māori development, including conferences and symposia, such as the 1994 Hui Whakapūmau Conference held at Massey University to look at the end of the decade of Māori development; the 1998 Māori Research and Development Conference Te Oru Rangahau; and the 2000 Conference Toi te Kupu, Toi te Mana, Toi te Whenua: Māori Development in a Global Society/Millennium Conference: 'Live the Legacy'. ${ }^{76}$ Edwards concludes his analysis of Māori development by discussing the rapidly changing world of the twenty-first century with its challenges of new technologies, global markets and knowledge

70 Ibid. 78.

71 Ibid. 76. See Hill, Richard S. State Authority, Indigenous Autonomy: Crown Relations in New Zealand/Aotearoa 1900-1950. Wellington: Victoria University Press, 2004. Hill says that Ngata's motives in helping to prepare the Native Land Act was "as always, the desire to preserve as much Māori culture as was compatible with the benefits and inevitabilities of 'western' civilisation" (p.100).

72 Ibid. 212. TACSA (Te Aute College Students Association) was established in the early 1890s to arrest the social, economic, cultural and spiritual decline of Māori people. The principal of Te Aute, John Thornton, was its prime mover while Apirana Ngata was its driving force. TACSA was used as the platform to launch Ngata's political career (p.74-79).

73 Ibid. 212.

74 Kersey, 2000, 12.

75 Ibid. 12. Durie, 2003.

76 Edwards, 2010, 13. 
societies, environmental concerns like global warming and water, education disparities and unemployment.

In a similar way to Edwards, Durie also describes key phases of Māori development that include the following:

1. Period One: Te Whakamāuitanga: Recovery 1900-1925

2. Period Two: Tūpunga Ahuwhenua: Rural Development 1925-1950

3. Te Hekenga-mai-Kāinga: Urbanisation 1950-1975

4. Period Four: Te Tiriti: Claims, Settlements, Autonomy 1975-2000

5. Period Five: Māori Development 2000-2025

Durie has detailed a century of Māori development along with the strategies, patterns and directions that the development entailed. He notes that each phase builds on the progress of the earlier periods, but is characterized by its own patterns and features. Within these phases emerge commonalities that Durie believes we can draw from to build frameworks for future Māori development. ${ }^{78}$ In Period Four, for example, he states that the 1984 Hui Taumata (Māori Economic Summit) codified Māori development and "subsequently promoted as an apt descriptor for the conversion of Māori aspirations into action and outcomes." ${ }^{, 79}$ Some of the challenges that Durie notes for this future Māori development state include Māori-Crown Relationships, Māori to Māori relationships and Economic development. ${ }^{80}$

With respect to Period Five (Māori Development 2000-2025), Durie provides a Māori development framework in which an aim, amongst others, is "the development of Māori as Māori." ${ }^{81}$ Durie says: "the starting point is that Māori want to retain the distinct identity that

77 Durie, 2003, 87-103.

78 Ibid, 87.

79 Ibid. Puketapu (2000) says that the Hui Taumata provided a forum to promote the Labour Government's economic agenda where emphasis was placed on translating negative government expenditure to positive areas in order to accelerate Māori economic development. Iwi tribal development was promoted as an appropriate means of programme delivery to Māori and "enhancing Māori wellbeing was framed to include social and cultural aspirations rather than separating them from Māori economic development" (p.56).

80 Ibid, 95.

81 Ibid, 96. 
comes from a unique heritage, common journeys, a familiar environment, and a set of shared aspirations. It is about being Māori and being part of te ao Māori." ${ }^{82}$

Davis also recalls the connections with the past as patterns left by the ancestors to guide future economic development. For Davis, the model for Māori wealth creation and economic sustainability is expressed in her model titled 'Te Ao Maioha' and includes mana atua (spiritual wealth), mana taiao (environmental wealth), mana tangata (social wealth) and mana reo (cultural wealth). ${ }^{83}$ For Davis, there is interconnectedness between these dimensions that provide the basis for mana reo to be expressed. ${ }^{84}$

Brendon Puketapu discussed development theories and the nature of Māori development and, like Durie, supports the quest for tino rangatiratanga or self-determination as an understandable feature of a Māori-centred approach to development. He believes that there is no universal model for Māori development, but it is best conceptualized as a matrix of variables that are concerned with the translation of Māori ideals into Māori realities. ${ }^{85}$ Regarding development, Puketapu recognizes the need for Māori organizations to reflect and respond to a Māori identity:

The complexities of Māori identity are central to Māori development goals and objectives especially when interaction extends beyond tribal parameters. As Māori development is predicated on the assumption that Māori people are principally involved then the diverse nature of the Māori identity in contemporary circumstances is inextricably connected to all the dimensions that encapsulate what being Māori means. ${ }^{86}$

Puketapu believes that Māori development must be in line with, and responsive to, modernity and the contemporary lives of Māori. He writes that "the search for a Māori development framework is best served by an approach that is responsive to the contemporary circumstances of Māori people." ${ }^{\text {87 }} \mathrm{He}$ further adds that "if Māori self-determination is the destination then the journey is best guided by a Māori centred approach to development and

\footnotetext{
Ibid.

See Davis, 2006, 64.

Ibid, 63.

Puketapu, 2000, 315.

Ibid, 315.

Puketapu, 2000, 119.
} 
organizational arrangements that are cognizant of the contemporary circumstances, in particular the relationship dynamics that challenge Māori and the life choices they make." ${ }^{, 8}$

Moon is another writer who has examined selected phases of Māori development in the nineteenth and twentieth centuries through the application of modernization theory and in particular the significance of 'intentional development' as advanced by Cowen and Shenton (1996). ${ }^{89}$ Intentional development refers to a deliberate attempt to develop and where this is usually coordinated by the State. ${ }^{90}$ Moon says that the implicit assumption of this modernization theory is that non-westernized societies are somehow viewed as incapable of bringing about their own development and require an external power to guide them. He notes: "following the conclusion of the Treaty of Waitangi, the Government fulfilled the role of a guiding power when it came to matters of Māori development.",91

\section{Māori development - culture and identity}

The importance of culture and identity for Māori development is something that is shared by many Māori leaders. Commenting on tino rangatiratanga, Kara Puketapu expressed the view that "It's no use talking about tino Rangatiratanga unless you end up equally rich in your culture." 92 Kara is a great example of a leader who has championed Māori development, but not compromised this without due consideration of the value of culture. The Tu Tangata initiative was Puketapu's form of Māori sovereignty for the late 1970s and Puketapu was quite adamant that Māori needed to shake themselves free from the bureaucratic dominance and stand tall in their own culture: "Let culture be the catalyst for all things." "93 Shane Jones is another writer who has written about museums, tourism and Māori development. Jones acknowledges the importance of museums to Māori development when he says: "it [i.e. the museum] has enormous wealth in terms of customary heritage. It holds the substance which is so often required to complete tribal strategies of restoration and rebuilding." "94 Jones adopts a similar position to Puketapu and Mason Durie about the nature of Māori development and

88 Ibid, ii. Puketapu believes that Māori must reflect and build on the wide range of relationships between hapū and iwi, individual and collective, tribal and non-tribal and Māori and the Crown. He further notes that the resources needed to advance the transformation of relationships between Māori at a local, national and international level are through whanaungatanga and manaakitanga (p.312).

89 Moon, 2004.

90 Ibid. 34.

91 Ibid. 35.

92 See Melbourne, Hineani. 1995. Maori Sovereignty: The Maori Perspective. Auckland: Hodder Moa Beckett., 52.

93 Ibid. 46.

94 Jones, 1994a, 77. 
the place of culture and says that the Māori economy must achieve economic benefit but not at the expense of cultural degradation: "Such an economy must be linked to the tourism sector. The contribution of Māori, however, must be one which achieves economic benefit without cultural degradation.",95

For Shane Jones, the primacy of culture and its central importance for a modern Māori identity is both about the individual and the collective, the hapu and the iwi.

Given the primacy accorded to culture and its central importance in defining the modern identity of Māori, it is not surprising that there has been a growing interest in revitalizing the identity and the operational capacity of the tribes... The losses may have been suffered by individuals and their personal circumstances may have been blighted, but the repository of the rights is the collectivity. It is asserted that by doing this, the integrity of the culture is safeguarded and the identity of the individual is assured, along with the tribal patrimony. ${ }^{96}$

It is certain that Māori development is not only about the relationship between Māori and the Crown but also between Māori and Māori, including between individuals and collectives and an array of Māori organizations. These individuals and leaders, as Durie observes, have made their mark in commerce, law, sport and academia and, irrespective of the fact that sometimes the relationships are strained, they have nevertheless through synergies "led to innovative approaches to development that have added strength to Māori self-determination." ${ }^{\text {97 }}$ Durie further notes that Māori development cannot ignore the realities of modern New Zealand and the global influences that impact on us. Māori identity is arguably at the heart of Māori selfdetermination as Durie reminds us: "Māori self-determination is a shallow goal if a Māori identity is not part of the equation." $" 98$

Many Māori tribes are actively engaged in the future development of their people and embarking on their own self-governing futures. An important part of this quest for tino rangatiratanga or self-determination is the creation of strategies and pathways to better the lives of their tribal people, whether that is economic, social, cultural and/or political. In Chapter Three we saw how the southern Ngāi Tahu tribe has adopted a development strategy

95 Ibid

96 Jones, 2006, 165.

97 Durie, 2003, 3. Durie argues the rhetoric must be put into action and be underpinned with sound conceptual foundations, clarity of purpose and a capacity for measuring progress and impact.

98 Durie, 1998a, 79. 
that takes as its guiding ethos the words 'Mō Tātou, ā, mō kā uri a muri ake nei' (For us and the generations after us). This ethos clearly signals the intergenerational thinking for their tribal development.

In 2010 a large number of Māori tribes came together to share their visions of the future. ${ }^{99}$ The aim of the conference was to contemplate the challenges and highlights of realizing iwi potential and incorporated three main areas:

\section{Aspirations in a Post-Treaty Settlement environment}

\section{Learn from each other}

3. Launch the institute of Post Settlement Futures and install the inaugural chair.

Two iwi spokespeople who made presentations on the nature of Māori development reinforced the importance of the cultural dimensions of Māori development and the need to plan for future generations. Insley noted the importance of the culture with respect to development: “As iwi businesses grow we must never lose sight of what makes us Māori Our language, our culture, our heritage. This is the only source of sustainable competitive advantage. ${ }^{\prime 100}$ Insley talked about intergenerational planning horizons and the need to fasttrack iwi technology strategies. He noted that there is no need to reinvent the wheel - we must find the world's best practice, import it, adapt it and modify the technology and apply it. Sir Tipene O’Regan of Ngāi Tahu noted that the Māori economy and economics are about people, our people, and that all iwi seem to voice the intergenerational nature for future generations. ${ }^{101}$ O'Regan said that iwi need to construct a different kind of economic model and that we need to write our own script and work on how to do it. For O'Regan, leadership and imagination are critical factors in this model.

These comments are insightful as we consider the role of tribal taonga with regard to Māori tribal identity and Māori tribal development. Tainui and Ngāi Tahu were the first two large

99 In 2010 the Te Pourewa Arotahi: The Elevated Platform for Resolution Symposium was hosted by Te Whare Wānanga o Awanuiārangi in partnership with Te Rūnanga o Ngāti Awa at Te Papa from $29^{\text {th }}$ to $30^{\text {th }}$ November.

100 Chris Insley was one of the speakers at the symposium and is actively involved in development initiatives for the Ngāti Porou tribe.

101 O'Regan's paper was titled 'Developing enduring tribal economies.' O'Regan was one of the architects of Ngāi Tahu's development success and was the Chairman and member of the Ngāi Tahu Māori Trust Board from 1973 to 1996. 
Māori tribes that settled their historic Waitangi Tribunal claim grievances in the $1990 \mathrm{~s} .{ }^{102}$ An important component of their Waitangi Treaty settlements included strong cultural redress provisions along with financial payments that have since greatly assisted their tribal development initiatives. For many, the post Treaty settlements era is not only about addressing past injustices, but equally important in providing development opportunities for iwi to invest in their people's future wellbeing.

With regard to Māori development and the historic grievances of the Waitangi Tribunal settlement process, Jones recognizes that this involves both economics and the roots of identity - mana. Jones believes that mana and an affirmation of mana is vitally important within the Waitangi settlement process and the key words are that "Development cannot be sustainable if mana is not left intact." As Jones points out:

The importance of the settlement of historical grievances is bound up with the affirmation of mana and the transfer of capital. Development cannot be sustainable if mana is not left intact. It represents the link with the past, both ancestral and divine, the roots of identity, as reflected in the well-known saying, He purapura $i$ ruia mai $i$ Rangiatea, e kore au e ngaro - A shoot planted in Rangiatea, I will not be lost. ${ }^{103}$

Jones also provides a useful way to articulate the relationship between tourism, Māori development and cultural objects or taonga. Jones believes that tourism is about place and space and that Māori development experience is also about these two concepts. He says that place is defined through association and that this raises the importance of relationships and whakapapa or kinship, which Jones describes as the cosmic metaphor in the Māori world. Jones believes that space is defined through symbol and that traditional cultural objects have a great role to play in Māori identity: "They define a space which is shared by the architect of the taonga, the enquiring descendant and the Atua." 104 Tensions undoubtedly exist between indigenous and mainstream western ideologies and this can be seen in the Waitangi Tribunal claims environment where the drive to invest and grow your pūtea in financial terms is balanced with the desire to look after the people and culture.

Māori people are a transnational people and are located in all parts of the world and, in particular, Australia. Given this reality, Māori development has transnational potential. In a report on Māori in Australia in 2007, Hamer makes the assertion that Māori development

102 The Ngāi Tahu Waitangi Tribunal claim was settled in 1997 while Tainui settled their Waitangi claim in 1995.

103 Jones, 2006, 166.

104 Jones, 1994a, 77. 
should no longer be simply in terms of the New Zealand nation state, given the transnational nature of the population. He says: "Māori economic success in Australia is a potential impetus for Māori development in New Zealand, just as the Māori cultural revival in New Zealand can offer much-needed sustenance to Māori in Australia." 105

For Pita Sharples, the former Chairman of the Ngāti Kahungunu tribal authority and former Minister of Māori Affairs, Māori development is development according to Māori aspirations. ${ }^{106}$ Sharples believes that Māori development spans across generations and across centuries, operating in many realms, including the return of our ancestors from overseas museums ${ }^{107}$ - restoring connections, valuing taonga, engaging in international negotiations for something at the essence of our cultural heritage. Sharples speaks of a culturally diverse and multifaceted view of development and poignantly says: "But all the assets in the world will be valueless if the people have lost the very essence of who they are." ${ }^{108}$ Sharples noted that "economic development is critical. But our progress cannot be accomplished without having regard for our values and the realities of modern Māori living.",109

In November 2009, Sharples noted how Māori development spans across generations and centuries and promotes social equity and cultural affirmation, while at the same time stimulating economic self-sufficiency. For Sharples, Māori development is development according to Māori aspirations. Like Paulin's ${ }^{110}$ model of development, as noted in Chapter Three Sharples cites Anderson's economic development model for the aboriginal people of Canada in 1999. This included:

1. attaining economic self-sufficiency as a necessary condition for realizing selfgovernment

2. improving socio-economic circumstances for aboriginal people

3. preserving and strengthening traditional culture, values and languages and reflecting the same in development activities.

\footnotetext{
105 Hamer, 2007. xi.

106 Sharples, P. 2009 'Māori Development' Manu Ao Academy Seminar, 18 November 2009.

107 This is in relation to ancestral remains being returned from museums in Sweden in November 2009.

108 Sharples, P. 2009.

109 Ibid.

${ }^{110}$ Paulin, 2005.
} 
The notion of a living culture and the continuity with the past is something that the wellknown Māori leader and academic Whatarangi Winiata agrees with. Winiata is a champion of Māori self-determination and has occupied key positions over the last 30 years in pursuit of improving and advancing Māori interests. Winiata helped establish Te Wānanga o Raukawa in 1981 and was its tumuaki from 1994-2007. He helped create the tribal development plan of Ngāti Raukawa, Te Atiawa and Ngāti Toa Rangatira known as Whakatipuranga Ruamano 2000 to advance iwi and hapū economically, socially and educationally. He was also Professor of Accounting at Victoria University and founding President of the Māori Party in 2005.

When talking about the importance of Māori taonga, archives and records, Winiata believes that, rather than being seen as passive agents in their connection to the past, the information and mātauranga Māori held in libraries, museums and allied organizations are critical in terms of the survival of Māori as a people. In support of an ongoing development of Māori into the future, Winiata writes: "Excellence in Māori archiving is to be assessed by the contribution to securing Māori as a people. Māori archives are not an end in themselves but contribute to the continuum of mātauranga, of worldviews, of the future development and growth of Māori into the future." "111 The notion of a 'living' culture with a continuity and relationship with the past is highly relevant to museums, given that they possess large quantities of Māori taonga. Recognizing this dimension will mean new paradigms and directions to ensure that Māori continue to develop and grow into the future.

The close relationship between the past, present and future for Māori is very evident in Māori development scenarios. Winiata reminds us of the ongoing importance of taonga, such as archives, manuscripts, photographs and whakapapa, and in a way informs us of how Māori have been alienated from their cultural foundations through the process of colonization. For Māori leaders like Whatarangi Winiata, Pita Sharples and Hirini Mead, dispossession must be replaced with repossession for the future development of Māori. This supports the view of Sissons when he says: "If colonisation was and is dispossession, then the futures of first peoples will be built on repossession." 112

111 Whatarangi Winiata was the keynote speaker at the ARANZ Conference 'Nga Taonga Tuku Iho: Treasures Passed Down: Māori Archives and Records' held in Rotorua in 2004. Winiata reminded everyone of the continuum of mātauranga Māori as a living entity in support of Māori as a living culture.

112 Sissons 2005, 140. Sissons also makes the point that if assimilation was separation then repossession is about reconnection. (p.143). 
A literature review in the Te Pae Tawhiti Māori Economic Development Programme in $2011^{113}$ looked at the concept of 'development' and its relationship to indigenous peoples. This was seen as a precursor to looking at what we mean by 'Māori economic development'. The report noted how development is often described as a process of economic, social and political wellbeing. ${ }^{114}$ Under the section on 'Development and Indigenous Knowledge', the report noted the argument about the role of cultural influences on economic development processes with some saying that it is a moot point whether there is full understanding of how Māori values influence iwi economic considerations. ${ }^{115}$

However, contrary to this viewpoint, the report notes that some authorities insist that there is strong evidence that "Māori businesses are underpinned by a set of values and processes that are entrenched in iwi tikanga and knowledge frameworks." 116 This report is highly relevant to my research as it considers Māori economic development and what it is, and the themes and principles that emerge from this discourse. The report noted three specific projects that were aimed at addressing the research question in what are the critical success factors for Māori economic development: the establishment of an aspirational framework for Māori economic development; the design of innovative models and scenarios for Māori economic development; and the creation of a futures framework to transform Māori economic development.

The report examined a number of strategic plans, mission statements, websites and annual plans from six iwi - Ngāti Awa, Ngāi Te Rangi, Ngāpuhi, Ngāti Tahu-Ngāti Whaoa, Ngāti Kahungunu and Te Whānau-a-Apanui. Particularly important for this research are some of the preliminary findings that relate to the importance of culture and identity.

Without exception, each iwi vision and mission statement placed the wellbeing of the marae, whānau and hapū as the key objective. One example from Ngāti Mutunga stated that the iwi's vision was to secure that it "is culturally strong, secure in its identity and

\footnotetext{
113 The project is one of Nga Pae o te Maramatanga's major projects with an aim to "harness the energy of the emerging Māori economy to the full benefit of iwi and Māori through analysing and assessing practices and strategies that will enable Māori economic self-development located in their own aspirations." (See Carter, Lynette, Rawinia Kamau, and Mereana Barrett 2011, 6).

114 Carter, Lynette, Rawinia Kamau, and Mereana Barrett. "Te Pae Tawhiti Māori Economic Development Programme Literature Review and Programme Report". Nga Pae o te Maramatanga The University of Auckland: Norcross, November 2011. (p.8).

115 Ibid. The report cites the following authorities - Edlin, 2005, p.1; NZEIR 2003, p.35.

116 Ibid. The source for this information is Ryan, 2011; Te Puni Kōkiri, 2010.
} 
economically prosperous” (Te Rūnanga o Ngāti Mutunga Strategic Plan 2008-2013). The Ngāti Mutunga mission is "to facilitate the growth and development of our people and our culture, Ngāti Mutunga ..." "117

O'Sullivan says that for Ngāti Whatua the connection between economics, politics, educations, health and culture is clear: "Economic development is central to reclaiming tribal Rangatiratanga."118

In making conclusions, the literature review report and programme report noted that in a post-settlement environment the "treaty settlements allow iwi to reassert mana and in particularly mana over the various regions, resources and people that form their whakapapa." 119 And like Mason Durie, the report says: "The most important factor from Treaty Settlements is not their contribution to economic performance, but their longer-term contribution to iwi economic development: socially, culturally and politically."

The Ngāti Whatua Heru Hapai is a kaupapa and initiative of Ngāti Whatua. The publications released by Te Rūnanga o Ngāti Whatua include Ngāti Whatua strategies on cultural heritage, arts and creative strategy, education strategy and a language revitalization strategy.

Statements included in the strategies help to illuminate the role that Ngāti Whatua taonga play with regard to Ngâti Whatua identity and development. The end outcome is the reconnection of Ngāti Whatua people with Ngāti Whatua cultural heritage and identity:

I would like to present this cultural heritage strategy as one in this series. It has been designed to rediscover, recover and protect the cultural heritage information unique to Ngāti Whatua. The aim is to reconnect our people with their heritage and inspire them to build on this and apply it in new and innovative ways whilst protecting the integrity of the valuable legacy of our tupuna. ${ }^{121}$

The place that Ngāti Whatua arts occupy within their future is noted in the Ngāti Whatua Arts and Creativity Strategy. For them, the arts and taonga occupy a similar position to that of the language in relation to the culture:

117 Carter, L., R. Kamau, et al. 2011, 17.

118 O’Sullivan, 2007, 202.

119 Ibid.

120 Ibid.

121 See Ngāti Whatua Cultural Heritage Strategy. The strategy aims to strengthen the cultural heritage aspects of Ngāti Whatua identity by such things as identifying Ngāti Whatua taonga; facilitating access to Ngāti Whatua taonga; advocating for the physical and spiritual preservation and conservation of Ngāti Whatua taonga; advocating for the protection of Ngāti Whatua cultural and intellectual property; strategically planning for the appropriate application of cultural heritage information and taonga and learning about cultural heritage information management. 
Just as language is essential to culture, so it is fundamental to identity. The very same thing can be said about the arts. In fact the experience of iwi arts mirrors te reo in terms of its cultural origins, cultural applications, the transmission of specialized knowledge and the gradual decline over the past one hundred or so years. ${ }^{122}$

This chapter has shown that there are First Nation and indigenous peoples' assertions of sovereignty in the form of charters, legislation and policies. The Declaration on the Rights of Indigenous Peoples sets the agenda for building a self-determining future for indigenous people. Museums also have a role to play within this context with a particular focus on access to taonga, cultural development, regeneration and revitalization. The academic Moira Simpson advocates for the contemporary value of objects for living cultures, as opposed to seeing heritage as evidence of the past. Cultural centres are seen as examples of indigenous people taking control of their cultural futures.

As in the international context, Māori have asserted their sovereignty and self-determination over the last 150 years in the form of marches, protests, boycotts and movements. The 1970s is a period characterized by major projects directed towards self-determination, including the Tu Tangata, kohanga reo and Te Mãori exhibition. The chapter also examined the nature of Māori tribal development and noted the exponential increase in Māori tribal development initiatives largely through the post-Treaty settlements phase. Tribes are actively embarking on development initiatives and their tribal visions, mission statements and plans place culture as an important dimension. Māori tribal development is a manifestation of self-determination and Māori self-determination, as noted by Mason Durie, is a shallow goal if identity is not part of the equation.

Māori tribal development is not an isolated activity that has emerged in modern times but rather a continuous extension of a development ethos that has its origins in the time of the arrival of the early ancestors on twin-hulled, ocean-voyaging waka from Eastern Polynesia over 900 years ago. The arrival and adaptation to a new and vastly different environment with new resources meant the need to experiment and develop. This was done largely through continuity with skills and knowledge systems, experimentation and trial and error. The development ethos ensured that survival was achieved and that the people could thrive and grow. Edwards and Durie provided schemas to categorize the phases of Māori development. These phases closely align with what was happening at the time, for example, the reemerging leadership in the 1900 to 1950 period and urbanization and protests in the 1950 to

${ }^{122}$ Ngāti Whātua Arts and Creativity Strategy. 
1975 period. Both Edwards and Durie mention the Waitangi Treaty claims as an important focus on Māori tribal development. Tribal development has culture and identity as important elements of many tribes in their future development visions and strategic plans. Durie's notion of a 'secure' Māori identity has relevance in Māori tribal development. Durie's phase five (2000-2025) is particularly important as he believes the starting point is the development of Māori as Māori.

Although the 1984 Hui Taumata codified Māori development, there has been a steady growth in tribal development strategies aimed at growing investments and providing for a better quality of life for the people. This chapter has shown that culture and identity are important dimensions for Māori tribal development and that for many tribes taonga form an important part of this cultural foundation. Tribal leaders believe that economics and culture go hand in hand with respect to tribal development. Shane Jones reminds us that development is not sustainable if mana is not left intact. Sharples and Durie also note that development must take account of contemporary realities and needs, ensuring that we never forget who we are as Māori people.

Apirana Ngata's well-known saying 'E Tipu e Rea' provides a template for a Māori development model based on a bicultural world. Many writers and authorities support Ngata's philosophy, but a healthy and secure identity in Durie's terms reflects a holistic and interconnected world where Māori taonga and the institutions that hold them are important. The affirmation of mana and iwi being culturally strong and secure in their identity emerged as key features in Chapter Two. 


\section{Chapter Three: Mō Tätou, $\bar{a}$, Mō kä uri à muri ake nei- The Politics of Ngāi Tahu Tribal Identity and Development}

\section{Introduction}

This research dissertation seeks to understand the role that taonga play in the intergenerational sustainability of Māori development in economic, social and cultural terms. The main question that this research seeks to answer is: what role do Māori taonga play within contemporary Māori communities as part of tribal self-determination and the advancement of Māori development and identity? This chapter follows on from Chapter Two which considered the characteristics and dimensions of Māori tribal development. In Chapter Two it was shown that culture and identity are important dimensions for Māori tribal development and that for many tribes taonga are an integral part of a living culture with continuity to the past. The affirmation of mana and iwi being culturally strong and secure in their identity emerged as key features in Chapter Two.

This chapter examines Ngāi Tahu tribal taonga and the role they play in the lives of Ngāi Tahu people, past, present and future. Ngāi Tahu's guiding ethos for its tribal development is enshrined in the kupu korero 'Mō Tàtou, à, Mo Kā uri a muri ake nei' and highlights intergenerational planning for its sustainability in economic, social and cultural terms.

This chapter starts with a background to Ngāi Tahu by looking at the origins and history of the Ngāi Tahu tribe to provide an historical context and understanding of Ngāi Tahu history and identity through time. This is then followed by an examination of the Ngāi Tahu Waitangi Tribunal Kerēme or claim with respect to its history and significance. The claim occupied Ngāi Tahu leaders for over 150 years and an examination of the claim process with a particular focus on the cultural redress provisions was undertaken. What the claim represented, who was involved in it, and why it was, and still is, important to Ngāi Tahu will be shown. A section is also devoted to an examination of the tribal corporate entity, Te Rūnanga o Ngāi Tahu. Their policies, practices and operations with regard to Ngāi Tahu culture and identity, including Ngāi Tahu taonga, will be discussed.

Following on from the background sections will be an assessment of key Ngāi Tahu art and taonga projects including the Mō Tãtou Ngāi Tahu Whānui exhibition, the Te Ana Ngāi Tahu Rock Art Centre and the Ngāi Tahu Pouwhenua project. These projects include a description 
of the kaupapa and an assessment and analysis of them within the context of Ngāi Tahu tribal identity and development. Interviews with tribal members, along with documented sources, reveal a depth of insider understandings and perspectives.

This chapter is the first tribal case study that extends our understanding of the nature of Māori development and its relationship to tribal identity. Ngāi Tahu is an example of a large tribe that has settled their Waitangi Tribunal claim and advanced their tribal economic and cultural aspirations. Key Ngāi Tahu taonga projects, including the Mō Tâtou exhibition and the Ngāi Tahu Pouwhenua project, support achieving intergenerational sustainability in economic, social and cultural terms.

The politics of Ngāi Tahu identity are not simple or one dimensional, but rather complex and multi-layered. Identity in itself has been described as a game of mirrors as Friedman reminds us: "The constitution of identity is an elaborate and deadly serious game of mirrors. It is a complex temporal interaction of multiple practices of identification external and internal to a subject or population. In order to understand the constitutive process it is, thus, necessary to be able to situate the mirrors in space and their movement in time."1 Friedman's words are pertinent with respect to Ngāi Tahu tribal identity and articulating what this means both in time and space.

What defines and constitutes Māori tribal identity is at the heart of my doctoral study, along with an examination of the relationship between Māori tribal identity and Māori tribal development through the agency of taonga. There are a number of writers who address Māori identity, but one of the most influential is Mason Durie. ${ }^{2}$ Much of my writing and thinking aligns with his philosophies and practices. Durie's 'Te Pae Mahutonga' model is aptly named after the Southern Cross star constellation and includes the dimensions of Mauriora - access to te ao Māori; Waiora - Environmental Protection; Toiora - Healthy Lifestyle; and Te Oranga - Participation in Society. Durie's Te Pae Mahutonga is used as a symbolic map for bringing together the significant components of health and culture in an integrated, relevant and meaningful way. ${ }^{3}$

Durie's Mauriora dimension rests on a secure cultural identity which includes access to the indigenous world, including language and knowledge; access to culture and cultural

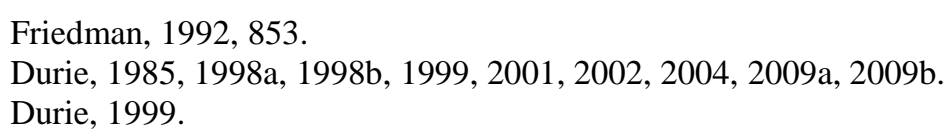


institutions, such as marae; and access to Māori economic resources, such as land, forests, and fisheries, as well as access to social resources, such as whānau. If we were to apply the Te Pae Mahutonga model to Ngāi Tahu people, we would find that Ngāi Tahu address many of these cultural dimensions.

Māori tribes are becoming more engaged with their cultural heritage and increasingly creating stronger cultural futures based on Māori language revitalization initiatives, history and cultural heritage kaupapa, and exhibition and artists programmes. One merely has to look at Māori tribal authority websites created to engage, connect and communicate with their kin and whānau to glean a sense of the ongoing importance of Māori cultural heritage to their future imaginations.

Ngāi Tahu is widely recognized and often promoted as a model tribe for Māori economic development. Its success story is about having successfully negotiated and settled their Waitangi Tribunal claim through to growing their economic asset base and embarking on a journey to restore and revitalize their social and cultural wellbeing. Paulin's Māori development framework based on the criteria that aided Ngāi Tahu's path to financial, cultural and social stability is a model that will be used in this research. ${ }^{4}$ This model is outlined below to show the key attributes and characteristics of a Māori development framework and one that applied to the world of Ngāi Tahu.

Paulin's Māori development framework incorporated the following.

The means

Primarily through financial and cultural redress for Treaty of Waitangi grievances, using such compensation to:

Regain control over traditional tribal lands and resources.

Create, operate and invest wisely in businesses that can compete profitably over the long run in the global economy, so as to:

- develop an asset base to ensure long term sustainability

- $\quad$ provide ongoing financial resources for the educational, social and cultural development of Māori.

Thus, attaining economic self-sufficiency as a necessary condition to achieve.

4 Paulin, 2005. 


\section{The ultimate purposes}

Improving the socio-economic circumstances of Māori people

Restoring political equality and respect between Māori and non-Māori

The preservation and strengthening of Māori culture. ${ }^{5}$

The research methodology included a literature review, archival and documentary research, and one-on-one kanohi ki te kanohi qualitative interviews with tribal members. The primary data for this research was gathered using the methods of personal interviews with key informants and collating information on Ngāi Tahu art and cultural projects. The Ngāi Tahu respondent interviewees include five key members of Ngāi Tahu who have been involved in Ngāi Tahu cultural projects.

Tipene O'Regan was the Chairman of the Ngāi Tahu Trust Board before the newly established Te Rūnanga o Ngāi Tahu tribal authority and was involved for over two decades working on the claim and leading the Trust Board. Mark Solomon is the present Kaiwhakahaere (Chairman) of Te Rūnanga o Ngāi Tahu who has held that position since 1998. Professor Piri Sciascia has been actively involved in Ngāi Tahu affairs for many years and was the deputy chair of the Iwi Steering Group of the Mō Tãtou exhibition. Puamiria Parata-Goodall works for the tribal authority as events manager and is actively involved in the cultural affairs of the tribe. Megan Tamati-Quennell acted as the curator of Mó Tätou and has extensive experience as an indigenous art curator at the National Museum. Megan also spent time working for the Ngāi Tahu tribal authority in the culture and identity portfolio.

\section{Ngāi Tahu origins}

The first Māori tribal case study is Ngāi Tahu of Te Waipounamu, South Island. This tribe will be examined to assess the proposition that Ngāi Tahu taonga do have a relationship with Ngāi Tahu tribal identity and tribal development. Ngāi Tahu is a well-known Māori tribe in modern New Zealand society and perhaps more so because of their high profile Waitangi Tribunal settlement with the Government and their subsequent high-flying economic success.

The Ngāi Tahu tribe is often recognized in New Zealand by both Māori and Pākehā as one of the leading Māori tribes with stellar economic and commercial success. Ngāi Tahu was the

5 Paulin, 2005, 205. 
first to settle their historic Waitangi Tribunal claims in 1998 after almost 150 years since it first questioned the land-selling methods in Te Waipounamu. It was also the first large Māori tribal claim that the Waitangi Tribunal had heard since it had been given increased powers to investigate claims dating back to 1840 .

The history of Ngāi Tahu is not unlike other Māori tribal histories that recount and recall important Pacific voyaging waka, distant ancestors and migrations and journeys through time. What is presented here is not exhaustive, as this has already been covered in great detail in the Waitangi Tribunal Research Claims process. What is covered are some of the main nexus points associated with Ngāi Tahu's origins and settlement.

To fully understand Ngāi Tahu today, however, we must take a journey and consider the origins of the Ngāi Tahu tribe. The tribal histories and narratives of Ngāi Tahu have shaped them and continue to inform and transform them in the future development of their people. Ngāi Tahu is the principal Māori tribe in Te Waipounamu, South Island, and the fourth largest tribe in New Zealand with 49,185 tribal members, according to the New Zealand Census taken in 2006. ${ }^{6} \mathrm{Ngāi}$ Tahu have one of the largest land territories of all Māori tribes in New Zealand with its tribal boundaries covering most of the South Island from Te Parinui-o-Whiti (White Bluffs) on the east coast to Kahurangi Point on the west coast, and southwards to Rakiura (Stewart Island). ${ }^{7}$ Of the nearly 50,000 Ngāi Tahu tribal members, 50 percent live outside the tribal rohe. ${ }^{8}$

Te Waipounamu is a large island land mass that extends some 200 kilometres wide and 850 kilometres south-west from Raukawa moana to Murihiku. ${ }^{9}$ Travel and migration is a familiar dimension of many Māori tribes, but for Ngāi Tahu the migration story is quite remarkable given that the internal migrations from the North Island in areas such as Wairoa and Napier

Statistics New Zealand Te Ao Mārama 2012 - Ngāpuhi is the largest Māori tribe with 122,211 tribal members followed by Ngāti Porou $(71,910)$, and Ngāti Kahungunu $(59,946)$.

7 Te Ara Encyclopedia of New Zealand: Ngāi Tahu (p.3). Accessed on 6 June 2012.

8 Solomon, Mark. 2006. "Ngāi Tahu Post-Settlement”. In State of the Māori Nation, edited by Malcolm Mulholland, 209-217. Auckland: Reed. 214.

9 Evison, Harry. 1997. The Long Dispute: Māori Land Rights and European Colonisation in Southern New Zealand. Christchurch: Canterbury University Press. 5. 
on the east coast amounted to over half the distance travelled, as compared to their Polynesian predecessors on ocean-voyaging waka some 800 years ago from Hawaiki. ${ }^{10}$

Southern New Zealand or the South Island is called 'Te Waipounamu', or the greenstone waters, named after the treasured and highly valued pounamu or greenstone that is found in its locale. The landscape of Te Waipounamu is rich in natural beauty with rocky bluffs and reefs, plains and estuaries, dangerous ocean currents, deep inlets and fiords, and steep mountain ranges too harsh for human settlement. The early inhabitants would have encountered a rich abundance of fish species in the waterways in and around Te Waipounamu and an array of birds and wildlife from the land environment.

Te Waipounamu teemed with a plentiful supply of food sources, including birds, eels, numerous fish species, and other wildlife. The tîtī or mutton birds on the islands of Rakiura supported an invaluable source of food supply in the historical period and to this day remains an important source of food for Ngāi Tahu descendants. The large and plentiful supply of fish species around the waters of Te Waipounamu also meant that the early inhabitants needed the technology to catch them.

Scattered in museums throughout New Zealand and overseas are a large array of elaborate fishhooks and fishing equipment that show the ingenuity and skill of these early peoples to adapt to their environment. The harsh and cold environment that the early inhabitants encountered provided the people with the tools necessary to live in harmony with it and to sustain a life for their whānau and kin. Like other Māori tribes at that time, the early Māori South Island inhabitants lived with their gods and deities as part of their natural world. The relationship with Papatūānuku (Earth Mother), the gods and the taiao or environment was intimate and connected through whakapapa.

The territory of Ngāi Tahu was rich in resources and the availability of these resources depended on the seasons and the times and nature of the resource. The Ngāi Tahu seasonal calendar provides a good example of the diversity of resources available in Te Waipounamu and the times that they were generally available. ${ }^{11}$ What is certain, as Evison notes, is that

10 Tau, Te Maire, and Atholl Anderson. 2008. Ngāi Tahu: A Migration History. The Carrington Text. Wellington: Bridget Williams Publishing. 20. Tau and Anderson estimate that Ngāi Tahu migrated some 1000 miles from the North Island which amounted to well over half the distance that the original early Pacific voyaging waka undertook from Eastern Polynesia or Hawaiki.

11 Anderson, 1998, 117, 126. 
"food and pounamu attracted people to Te Waipounamu and held them there."12 Trade and exchange of the rich resources also played an invaluable role in Ngāi Tahu society. Known as kai haukai, in reference to feasting, this trade was an important social and economic institution that operated at various levels where the distribution of commodities also served to reinforce the social order more generally. ${ }^{13}$

The history of Ngāi Tahu reaches back in time to the origin traditions of its peoples and the extensive migrations and journeys across time and space. Ngāi Tahu has a rich history that speaks about people, places, events and encounters. The history of Ngāi Tahu has been extensively researched in more recent times, notwithstanding the storehouse of historical material accumulated as part of Ngāi Tahu's Waitangi Tribunal claim process during the 1980 and '90s. ${ }^{14}$ This research material undoubtedly provides Ngāi Tahu with a wealth of historical and whakapapa material vital to their ongoing cultural futures.

For Ngāi Tahu, the mahinga kai generally refers to places at which food and other commodities were extracted or produced. ${ }^{15}$ Mahinga kai were, and still are, critical to sustaining a way of life, as was the importance of the knowledge and skill in harvesting and preparing the foods. As noted by Evison: "the organization of work reflected and sustained the social rankings derived from birth, inheritance, or prowess in War." ${ }^{16}$ More than 1400 mahinga kai were identified between Waimakariri and Matau Rivers in the East. ${ }^{17}$ As O'Regan notes: "Seasonal camps or Kāika nohoaka were established at all of the major mahika kai areas, and during the warmer months the harvesters would travel the length and breadth of the rohe to exploit these resources." 18

Mahinga kai are important to Ngāi Tahu because they an essential taonga or treasure pertaining to their unique economic culture. The mahinga kai were not just places where food

12 Evison, 1997, 19.

13 Anderson, 1998, 128. Anderson cites the example of a mutton bird exchange sequence between the Waikouaiti people led by Korokoro and relatives at Banks Peninsula. Large quantities were part of this exchange relationship.

14 See: Anderson, 1998; Dacker, Bill. 1994 Te Mamae me te Aroha: The Pain and the Love. Otago: The University of Otago Press.; Evison, 1986, 1988, 1993, 1997; Tau, Te Maire. 2003. Nga Pikituroa o Ngāi Tahu: The Oral Traditions of Ngāi Tahu. Otago: University of Otago Press.; Tau and Anderson, 2008.

15 Anderson, 1998, 111. Mahinga kai encompassed kumara gardens, eeling camps, rat runs, fishing reefs, mutton bird colonies, shell-fishing beds, birding trees, gardens, fern or tī kōuka patches, places to collect pounamu, flint, red ochre and so on.

16 Evison, 1997, 22.

17 Evison, 1997, 18. (Cited by Anderson: cited by Wai-27 R30 and H1.)

18 O'Regan, Hana. 2001. Ko Tahu, Ko Au: Kai Tahu Tribal Identity. Christchurch: Horomaka Publishing. 45. 
was acquired, but played important roles in the transmission and passing down of history and tribal knowledge. Recalling his upbringing, Te Maire Tau says:

Mahinga kai is where immediate contact is made with ancestral activities. Here, one learns of the location of family interests when gathering foods. Those interests include instruction about where family members are buried, the interests of other tribesmen and finally spiritual connections to mahinga kai through local spiritual guardians. The writer's knowledge of Ngāi Tahu traditions is from the 'bottom up', rather than through instruction from senior kaumātua or tohunga. ${ }^{19}$

Ngāi Tahu takes their tribal name from the ancestor Tahu Pōtiki, a descendant of Paikea and Porourangi of Ngāti Porou of the East Coast, North Island. ${ }^{20}$ For Te Maire Tau, the definition of Ngāi Tahu is: "Ngāi Tahu descend from a common ancestor called Tahu Pōtiki, who lived twenty generations ago. However, 'Ngāi Tahu' is now a generic term for older tribes of the South Island who have been incorporated within their authority. Those tribes are Waitaha, Ngāti Mamoe, Rapuwai, Ngāti Ira, Ngāti Wairaki and Ngāti Tumatakokiri." ${ }^{21}$ In the Ngāi Tahu Annual Report for 2011, the following is given with respect to who is Ngāi Tahu:

Ngāi Tahu is the iwi comprised of [sic] Ngāi Tahu Whānui; that is, the collective of the individuals who descend from the five primary hapū of Ngāi Tahu, namely Kāti Kuri, Ngāti Irakehu, Kāti Huirapa, Ngāi Tuahuriri and Ngāi Te Ruahikihiki, and the iwi of Ngāti Mamoe and Waitaha.

As Anderson notes: "Ngāi Tahu thus included not only those who, in various ways, acknowledged descent from Tahu Pōtiki - the origin of the tribal name - but also the tributary streams of earlier hapū and iwi who became intermarried with them - 'Ngāi Tahu Whānui' (the broader tribe of Tahu), as it is often expressed today." "22 Hana O'Regan expresses the streams of descent in this way: "The people developed in unison with this southern environment were from three principal streams of descent which eventually merged together in our histories to form the people we now refer to as Kāi Tahu." ${ }^{, 23}$

On the Te Rūnanga o Ngāi Tahu tribal website, the history of Ngāi Tahu is given concerning the three successive streams of migration. The first was the people who arrived under the leadership of Rakaihautū on the Uruao waka. The second was undertaken under the descendants of Whatu Mamoe who travelled down from the East Coast of the North Island and there become known as Kāti Mamoe who merged with the Waitaha peoples. Then we

19 Tau, 2003, 31.

20 Ngāi Tahu Waitangi Tribunal Report, 3.1, Ngāi Tahu Iwi.

21 Tau, 2003, 17.

22 Anderson, 1998, 13.

23 O'Regan, 2001, 45. 
have the father of the tribe Tahu Pōtiki, who was fathered by Paikea of the East Coast, North Island. The descendants of Tahu Pōtiki who formed Ngāi Tuhaitara and Ngāti Kuri moved south, travelling to Wellington first, under the leadership of Tu Ahuriri and Maru Kaitatea. From there Ngāti Kuri and Ngāi Tuhaitara migrated to Te Waipounamu where Ngāti Kuri established themselves at Kaikoura and Ngāi Tuhaitara at Kaiapoi pā. Through warfare, alliances and intermarriage they amalgamated with Waitaha and Kāti Mamoe. Today, the sub-tribes or hapū have become established around distinct tribal areas and predominantly form the Papatipu Rūnanga or modern-day Ngāi Tahu.

In the 1820 s to 1830 s, Ngāi Tahu were invaded by external tribes seeking land and the rich resources that were on offer. Ngāti Toa, under their chief Te Rauparaha, embarked on a relentless campaign throughout Te Waipounamu and this continued right up to the late 1830s. The Ngāti Toa raids were eventually repulsed, but the aftermath was severe for the southern peoples. About a third of the tribal territory was temporarily lost, about a fifth of the Ngāi Tahu population was killed or captured, and epidemic diseases were later introduced and women were lost to Pākehā men. ${ }^{24}$

By the time of the signing of the Treaty of Waitangi in 1840, Ngāi Tahu controlled vast areas of land "not as one tribe but as but like all iwi they existed in hapū and whānau communities, with different genealogies, often reflecting the mixed origins of the tribe." ${ }^{25}$ The Waitangi Tribunal Ngāi Tahu Report noted that, up to 1844, Ngāi Tahu owned more than half the land mass of Aotearoa and that only 20 years later that had been reduced to less than 38,000 acres. ${ }^{26}$ In the two decades (1844-64) following the signing of the Treaty of Waitangi, Ngāi Tahu were left with barely one acre out of every one thousand acres they once owned. By 1850 Ngāi Tahu had married into the early arrivals and most were Christianized. ${ }^{27}$

Ngāi Tahu has strong relationships with North Island tribes and in particular the tribes Ngāti Porou and Ngāti Kahungunu. With Ngāti Porou they share the founders of the two tribes, while with Ngāti Kahungunu there exists a strong relationship with the Takitimu canoe and

Anderson, 1998, 206.

25 Ngāi Tahu Waitangi Tribunal Report 3.1.10; Ballara, Angela Heather. 1991. The Origins of Ngāti Kahungunu. PhD, Victoria University of Wellington, Wellington. Ballara notes a similar situation for the formation of iwi and hapū in the early history of Ngāti Kahungunu.

26 Ibid. 24.5.6.

27 Armstrong, J. 1997. "Māori Identity in the South Island of New Zealand: Ethnic Identity Development in a migration context." Oceania no. 57 (3):206, 215. 
the origins of Ngāti Mamoe. These relationships are often acknowledged today and in part contribute to expressions of Ngāi Tahu tribal identity.

Ngāi Tahu's cultural values have remained steadfast throughout its historic period and continue from the past through to the present. From the ongoing importance of mahinga kai practices, such as tìtī or mutton birding, through to cultural and language revitalization initiatives, such as the Ngāi Tahu Māori Language Strategy 'Kotahi Mano Kāika, Kotahi Mano Wawata' (One thousand homes, One thousand aspirations). ${ }^{28}$ Ngāi Tahu remain committed to providing a better future for their descendants and those generations to come and this is expressed in projects that Ngāi Tahu are involved with. The Ngāi Tahu Seafood's Ahikā is another example where Ngāi Tahu values are applied to a modern economic enterprise as promoted by the Ngāi Tahu Seafood's Ahikā company: "It is the cornerstone of Ngāi Tahu spiritual, cultural, social, and economic well-being; and a symbol of Ngāi Tahu's continuing relationship with the traditions and history that place us on our land and our waters, and ties Ngāi Tahu Whānui together as an indigenous people."29

\section{Ngāi Tahu Waitangi Tribunal claim}

\section{"He Mahinga Kai Hoaka, He Mahi Kai Tangata"}

(It is work that consumes people, as greenstone consumes sandstone)

Of great significance to Ngāi Tahu has been Te Kerēme or what has been commonly referred to as 'the claim'. The Ngāi Tahu Waitangi Treaty claim occupied Ngāi Tahu for well over 150 years and has become synonymous with Ngāi Tahu identity, past, present and future. As Hana O'Regan reminds us, the claim was sown in the hearts of the people as a symbol of the past and future and embodied the hopes and dreams of its people and their rakatirataka. ${ }^{30}$ Synonymous with the claim is the tribal saying and kupu kōrero 'Mō Tātou, $\bar{a}$, Mō Kă uri $\bar{a}$ muri ake nei - For us and our children after us.' This tribal saying was adopted by the former

\footnotetext{
28 'Kotahi Mano Kāika, Kotahi Mano Wawata' (One thousand homes, One thousand aspirations) was launched by Te Rūnanga o Ngāi Tahu in 2000.

29 See Ahikā website - http://ahikākai.co.nz/, accessed $12^{\text {th }}$ July 2012.

30 O’Regan, 2001, 78.
} 
Ngāi Tahu Māori Trust Board to guide the work of the iwi through the settlement and implementation of the Treaty of Waitangi claim (Wai 27). ${ }^{31}$

The Ngāi Tahu Waitangi claim was filed on $28^{\text {th }}$ August 1986 and it took two years to complete all the hearings. The claim was brought by Rakiihia Tau and the Ngāi Tahu Māori Trust Board. As the Waitangi Tribunal noted: 'The inquiry was extensive: over a period of $3 \frac{1}{2}$ years, 23 hearings were conducted and the Tribunal received 900 submissions and heard from 262 witnesses and 25 corporate bodies. The claim was presented in nine parts, known as the 'Nine Tall Trees of Ngāi Tahu'. Eight of these 'trees' represented the different areas of land purchased from Ngāi Tahu, whilst the ninth represented Ngāi Tahu's mahinga kai or food resources. A number of grievances were attached to each of the nine tall trees and these came to be known as the 'branches of the Nine Tall Trees'. There were also a number of smaller claims, which came to be described as the 'undergrowth' or ancillary claims. ${ }^{32}$

The first formal statement of Ngāi Tahu grievance about land purchases was made by Mātiaha Tiramōrehu in 1849 and, in the 1870s, Hōri Kerei Taiaroa began the pursuit of the Ngāi Tahu claim in Parliament. ${ }^{33}$ Mātiaha first took his petition to Queen Victoria in 1857. It is very clear that Ngāi Tahu suffered grave injustices for over 150 years and the Waitangi Tribunal Ngāi Tahu Report details all the injustices that impacted on Ngāi Tahu. On the Te Rūnanga o Ngāi Tahu website, the claim actions are clear for everyone to see:

The Tribunal cannot avoid the conclusion that in acquiring from Ngāi Tahu 34.5 million acres, more than half the land mass of New Zealand, for $£ 14,750$ pounds, and leaving them with only 35,757 acres, the Crown acted unconscionably and in repeated breach of the Treaty of Waitangi ...

As a consequence, "Ngāi Tahu has suffered grave injustices over more than 140 years. The tribe is clearly entitled to very substantial redress from the Crown". These "grave injustices" based on the "unconscionable theft" by the Crown were the basis of the claim which Ngāi Tahu pursued. As well as stolen land and food sources, fisheries and forests, the claim also relates to hospitals and schools, which Crown agents had promised would be built and provided for iwi in each area when the land purchases were made. ${ }^{34}$

31 In the 'Te Kaupapa o Te Whare: House of Tahu Cultural Sustainability Assessment Report' prepared for Ngāi Tahu Property Ltd (2006) the first inside page says that the vision (i.e. tribal saying) was adopted by the former Ngāi Tahu Māori Trust Board to guide the work of the iwi through the settlement and implementation of the Treaty of Waitangi claim.

32 Waitangi Tribunal Ngāi Tahu Report Summary 1991. Accessed on $6^{\text {th }}$ June 2012.

33 Te Ara: Encyclopedia of New Zealand -- http://www.teara.govt.nz/en/Ngāi-tahu/8. Accessed on $18^{\text {th }}$ September 2012.

34 Te Rūnanga o Ngāi Tahu website - http://www.Ngāi Tahu.iwi.nz/About-Ngāi-Tahu/Settlement/ClaimHistory.php. Accessed on $12^{\text {th }}$ June 2012. 
The Ngāi Tahu Deed of Settlement was signed at Kaikoura in November 1997 and the Ngāi Tahu Settlement Act was subsequently passed in 1998. The settlement included an apology from the Crown and a settlement of $\$ 170$ million, along with a number of cultural redress provisions, including the recognition of geographical place names, the symbolic return of Aoraki maunga and the recognition of mahinga kai. The restoration of rangatiratanga to Ngāi Tahu with their mana over their lands was an important dimension of the settlement process. $^{35}$

From a Waitangi Tribunal settlement of \$170 million in 1998 through to the post-settlement phase, this has now grown to $\$ 781$ million. ${ }^{36}$ Although this suggests a great example of a Māori tribal corporate entity, for the Kaiwhakahaere of Te Rūnanga o Ngāi Tahu, Mark Solomon, it was a pragmatic approach for Ngāi Tahu to build their net future on $\$ 170$ million. Solomon is adamant that although they have done well since the settlement, there still remained injustices: "So I think we have done good but it isn't fair and it isn't just."37

The Crown's apology also included a Ngāi Tahu saying: 'He mahinga kai hoaka, he mahi kai tangata' ('It is work that consumes people, as greenstone consumes sandstone'). This saying was composed by Hastings Tipa and it is important to Ngāi Tahu in that it was based on the fact that the claim took nearly 150 years to come to fruition. Just like the relationship between pounamu and sandstone, the claim recognized the very long and arduous journey that Ngāi Tahu ancestors endured in pursuit of their claims. ${ }^{38}$ As Hana O'Regan explains in the translation of the waiata 'E Hine', composed for the signing of the Deed of Settlement and the history that went into it, the metaphor of Te Tatau Pounamu or greenstone door was in relation to permanence and for the ancestors who kept the claim alive. ${ }^{39}$ Despite the hardships, impoverishment and deprivation the claim persisted as a driving and uniting force.

Ngāi Tahu suffered great loss with colonization and fast-changing conditions, but throughout this period Ngāi Tahu taonga, including mahinga kai cultural practices, were constant reminders of their ancestors and their past. As seen by the Mō Tātou Ngāi Tahu exhibition, these taonga were important markers and symbols of an enduring Ngāi Tahu identity for

35 Maaka, Roger, and Augie Fleras. 2005. The Politics of Indigeneity: Challenging the State in Canada and Aotearoa New Zealand. Otago: University of Otago Press.

36 Mark Solomon interview, October 2011.

37 Ibid. Solomon believed that this was not fair or just but over $90 \%$ of Ngāi Tahu tribal members voted to accept the settlement offer as part of the voting process.

38 O’Regan, 2001, 147.

39 Ibid. 
those in the present and future. This reality accords well with Peers and Brown when they say: "Particularly for indigenous peoples, for whom the effects of colonisation have produced rapid and wrenching change, museum artefacts represent material heritage and incorporate the lives and knowledge of ancestors. They are also crucial bridges to the future. For peoples whose way of life has changed dramatically but whose identity rests on historical cultural knowledge, artefacts offer the possibility of recovering a broad range of cultural knowledge for use in the present and future." 40

The claim was, and is still, all-important for Ngāi Tahu. In 1840, several high-ranking chiefs signed the Treaty of Waitangi and, by 1849, the Crown started defaulting on its Treaty relationship on the terms with respect to ten major land purchases dating from 1844. For Ngāi Tahu, the claim related to the pursuit of justice and redress for breaches committed against them since the signing of the Treaty of Waitangi in 1840. As Solomon notes, this also "included the Crown's failure to allocate one tenth of the land allocated to Europeans to be Māori reserve and the paying of a fair price for the purchase of land." ${ }^{41}$

Census-taking has been a recognizable feature of the Ngāi Tahu landscape since early contact and they have engaged, shaped and renegotiated the process in more modern times as a way to articulate their tribal identity. The blue book of 1848, where Ngāi Tahu leaders identified Ngāi Tahu living at that time, still informs the membership of Ngāi Tahu in modern times. ${ }^{42}$ Whakapapa still remains an important dimension to being identified as being Ngāi Tahu, as Hana O'Regan noted. She writes: "For the eight kaikōrero interviewed in the course of this study, whakapapa is the one essential criterion for Kāi Tahu identity. If a person has Kāi Tahu whakapapa they are considered to be indisputably Kāi Tahu."

For some, however, the census taken in the 1900s provided evidence for the erasure of Ngāi Tahu land ownership and territorial rights. For Ngāi Tahu, the census was as much about their indigenous resistance to settler colonialism. As Angela Wanhalla says: "Ngāi Tahu have revoked and reinvented census taking to account for culturally appropriate ways of understanding tribal identity... While census taking can be viewed as underpinning the dispossession of Ngāi Tahu, erasing them as a tribal entity in official eyes, the evidence of the

40 Peers and Brown, 2007, 523.

41 Solomon, 2006, 209.

42 Wanhalla, Angela C. 2010. "The Politics of 'Periodical Counting': Race, Place and Identity in Southern New Zealand”. In Making Space: Settler-colonial perspectives on land, place and identity, edited by Penelope Edmonds and Tracey Banivanua, 198-217. London: Palgrave Macmillan.

43 O’Regan, 2001, 53. 
1890 Commission in fact illustrates Ngāi Tahu persistence in the face of colonial practices." Wanhalla further noted that "Ngāi Tahu resisted the census, critiqued the process, engaged in population counts when necessary and, in 1890, forced officials to rework the census process to account for cultural practices." 45 The claim has been described as the 'holy grail' for Ngāi Tahu and was the vehicle which united the tribe. ${ }^{46}$ Mātiaha Tiramōrehu is often regarded as the 'father of the Te Kerēme'. For Anake Goodall, the CEO of Te Rūnanga o Ngāi Tahu, speaking at Parliament to celebrate Ngāi Tahu's 10-year post-settlement achievement, the cultural redress aspects spoke to the Ngāi Tahu heart and Ngāi Tahu face embedding the cultural and ancestral associations, because "it was restoring the permanence of iwi to their ancestral landscape." 47

The claim included 73 grievances. Mark Solomon said that the settlement was not fair or full and that money could never compensate our tupuna for the damage to their honour and the denial of their visions for Ngāi Tahu. \$170 million is 1 percent of the real loss Ngāi Tahu experienced over 100 years, as Solomon said during the 10-year celebration of the signing of the claim in 1998.

Ngāi Tahu also suffered the loss of the Māori language in Te Waipounamu and this is largely due to factors such as changing patterns of social organization, European settlement and intermarriage. ${ }^{48}$ Ngāi Tahu had the poorest language health of all Māori tribes with only three native speakers of the 40,000 tribal members. ${ }^{49}$ The report by Te Puni Kōkiri on the state of the Māori language in the South Island, Te Waipounamu notes that te reo Māori is still very much a language of a small minority within the entire population of Te Waipounamu. ${ }^{50}$

Any discussion about Ngāi Tahu will invariably involve kōrero on the politics of Ngāi Tahu identity and history. For some Ngāi Tahu people there has been a stigma and negative connotation associated with being Ngāi Tahu. This is perhaps no more evident than with the writing of Hana O'Regan when she writes: “The damage that can be done to a person's and a

44 Wanhalla, 2010, 212-3.

45 Ibid.

46 Tau, Te Maire. 1992. Kurakura Ngāi Tahu. MA, Canterbury, Christchurch. 346. (Cited by Highman 1997, 38.)

47 Goodall, Anake. 2009. “Aoraki Matatu - Being steadfast in Ngāi Tahu Identity”. In Governing and Running Māori Entities Intensive, edited by Continuing Legal Education, 9-20. Wellington: New Zealand Law Society. 2.

48 See: Te Puni Kōkiri Report published in 2009, 'Te Oranga o te Reo Māori i te rohe o Te Waipounamu: The Health of the Māori Language in the South Island 2006.'

49 O'Regan, Hana. "Toitu te iwi - A journey in the evolution of cultural identity". Te Kaharoa no. 2:77-88. 79.

50 Ibid. The report noted the high priority on the Māori language and noted the Ngāi Tahu revitalization strategy 'Kotahi Mano Kaika, Kotahi Mano Wawata' that was launched in 2000. 
tribe's self-esteem by the negative perceptions held by others concerning their identity should not be underestimated. Kāi Tahu have now faced generations of negative expectations and attitudes directed towards their tribal identity. They have had generations of being talked about as being 'not real Māori', 'plastic Māori', 'inadequate', and 'culturally incompetent.",51

Hana O'Regan's views on Ngāi Tahu identity both historically and contemporary are further reiterated by Gina Irish when she discusses the national census-taking from the 1870s.

"Census taking provided evidence for the erasure of Ngāi Tahu land ownership and territorial rights, while enumerators also reconstructed the tribal population as 'white' ... From the 1870s, at a time when Māori became subject to national census enumeration, Ngāi Tahu were claimed as the most 'European of the Māori tribes." 52 For many the national census-taking would have been viewed indifferently, but for Ngāi Tahu they not only used it but reworked and reinvented it to take into account their own cultural ways of understanding their tribal identity. ${ }^{53}$ Wanhalla even says: "Census was indigenous resistance to settler colonialism."54 Irish further notes that "While census taking can be viewed as underpinning the dispossession of Ngāi Tahu, erasing them as a tribal entity in official eyes, the evidence of the 1890 Commission in fact illustrates Ngāi Tahu persistence in the face of colonial practices." 55

This view of being less Māori or not Māori at all is also noted by Armstrong when she cites an informant with respect to South Island Māori: "lost the blood, lost the land, and lost the language." ${ }^{56}$ Challenging Kāi Tahu identity has been a lived reality for many Ngāi Tahu people. Today, however, Ngāi Tahu often take a prominent lead in the affairs of Māoridom and there is, as there always has been, no question that Ngāi Tahu is a legitimate tribe with mana, authority and status.

Smith and Ruckstuhl, who researched the Ngāi Tahu print media before and after the settlement, said: "Ngāi Tahu identity distinguished itself from the national identity of '"New Zealanders" as much as from other "Māori" communities. Distinctive features of Ngāi Tahu identity include (among others) a long history of intermarriage between Māori and settlers, a

O’Regan, 2001, 141.

Irish, Gina. 2010. "Te Puāwai o Ngāi Tahu Exhibition." Art New Zealand no. 134., 198, 205.

Ibid. 212.

Ibid. 198.

Ibid. 213.

56 Armstrong, 1997, 207. 
historically dispersed population, and a specific dialect." ${ }^{, 57}$ Like the claim, it also seems that the Ngāi Tahu print media through their flagship tribal magazine Te Karaka also played a key role in helping to revitalize Ngāi Tahu identity through its communications and promotions. ${ }^{58}$ However, for some, the Ngāi Tahu claim embodied "many of the tensions between iwi and ethnicity as vehicles for identity, organisation and entitlement." ${ }^{, 59}$ The politics of the mandating process and the treaty settlement process have outraged some who believe that the corporate body has no accountability to its people and whose leaders are in collusion with the government. $^{60}$

The Ngāi Tahu Waitangi Tribunal claim represented resilience and tenacity as successive generations kept it alive and refused for it to die. ${ }^{61}$ The Ngāi Tahu claim was never about money, but rather about rectifying past injustices and giving Ngāi Tahu a right to speak, a right to information, and the right to participate and engage. The Ngāi Tahu claim spoke strongly to the identity of Ngāi Tahu and how Ngāi Tahu could secure and honour it for all time. The claim became the code word for resilience and resilience is at the heart of Ngāi Tahu. This can be seen through the long, arduous journey of the claim through to contemporary times where tenacity and resilience is being used as a core principle of Ngāi Tahu development.

The perseverance, struggle, resilience and tenacity of Ngāi Tahu with respect to the claim can be likened to Message's use of the metaphor of 'survivance' where you do whatever is necessary to keep the culture alive as part of a focus on self-determination and selfrepresentation. ${ }^{62}$ For Ngāi Tahu, the claim was not only about a framework of grievance and restitution, but equally about holding on to ancient principles and embracing change based on a focus of self-determination to keep the culture alive. Hana O'Regan's metaphor of Te Tatau pounamu in her waiata 'E Hine' composed for the signing of the Deed of Settlement represented the permanence and the ancestors who kept the claim alive. Although there was deprivation, impoverishment and hardship the claim became a driving and uniting force for

57 Smith, Jo , and Katharina Ruckstuhl. 2010. "The case of Te Karaka: Ngāi Tahu print media before and after settlement”. Alter Native no. 6 (1):25-37. 30.

58 Ibid

59 Maaka and Fleras, 2005, 89.

60 Ibid.

61 O'Regan, 2001.

62 Message, Kylie 2006. New Museums and the Making of Culture. Oxford \& New York: Berg.Message says that survivance means raising the social and political consciousness and holding onto ancient principles while eagerly embracing change. "It means doing what is necessary to keep cultures alive" (Ibid. 1). 
the iwi. ${ }^{63}$ Ngāi Tahu's experience is similar to Message's notion of 'survivance' as a "means of redefining ourselves. It means raising our social and political consciousness. It means holding onto ancient principles while eagerly embracing change. It means doing what is necessary to keep cultures alive."64

It is certain that cultures do not fit one size and that every identity carries a conception of its past and its future, as Ross Poole reminds us. ${ }^{65}$ Poole's writing regarding the relationship between culture and identity provides a good platform for an examination of the Ngāi Tahu tribe and their taonga. Poole notes how the relationship of the past with the present is invariably connected with notions of identity and that, with this relationship to the past, we make ourselves one with both the past and future. ${ }^{66}$ For Ngāi Tahu the claim became the bridge and connector to the past and by association those many ancestors who were associated with it.

Tipene O'Regan reminds us about how cultural activities, such as mahinga kai, are so important to Ngāi Tahu identity and how their tribal experience differed from other tribes, such as when he points out: "We don't have Mataatua houses to reconstruct the Te Hau ki Türanga to deal with. Traditionally the arts in our culture have not been fixed in place in the way Te Ika a Maui people or northern Māori have had. Because Ngāi Tahu tribal life is one of constant travel through seasons. Huge cycles of movement. Continually on the move. And so your cultural identity is found through your ability to make mokihi, to preserve food with poha, technology."67

For Ngāi Tahu, whakapapa is the glue that binds and connects people to their land, to the world around them, to their origins and to their sense of who they are. As a strong symbol of identity, whakapapa is central to Ngāi Tahu being and Ngāi Tahuness, as Tipene O'Regan points out: "My Ngāi Tahu whakapapa gives me an identity with place, and an identity with history and tradition, with place names, with mythology, with a whole lot of things that I can say, together with twenty-six thousand others - those things are mine. They are me. And I think, therefore, that Kāi Tahutaka is at the core of my being." ${ }^{\text {,6 }}$ The importance of whakapapa as a cornerstone of Ngāi Tahu identity was expressed by tribal members and for

63 O'Regan, 2001.

64 Message, 2006, 1

65 Poole, $1999,119$.

66 Ibid. 64.

67 Tipene O'Regan interview, October 2011.

68 O'Regan, 2001, 51. (Tipene O'Regan was interviewed on $18^{\text {th }}$ June 1996.) 
Piri Sciascia whakapapa was a vital component of tribal identity, as was the creative expressions of the taonga and their korero. As Sciascia noted:

It's got to start with whakapapa. I don't think you get away from that in anyway... I actually believe that identity is not a singular process. A lot of people make their identity from a whole range of ways, you know, about just being human but there are certain powerful things that a culture will shape and ours is whakapapa because we are one of the people... well to me the taonga and the kōrero that go with the taonga, and the people that go, as we've had this with Te Mäori before. You get to see, the people are your whakapapa, the taonga is the creative expression it comes from an artist that makes this thing and the kōrero. You put all those three together and this becomes one of the cornerstones of identity because depending on what it is. ${ }^{69}$

\section{Te Rūnanga o Ngāi Tahu}

The recognized tribal authority and legal entity of Ngāi Tahu is Te Rūnanga o Ngāi Tahu which is based in Christchurch. The Ngāi Tahu corporate entity is composed of 18 papatipu rūnaka representatives from throughout the tribal territory of Ngāi Tahu. The mission of the tribal authority is to work on behalf of the iwi to manage the collective assets of Ngāi Tahu whānui and to promote and ensure the interests and aspirations of Ngāi Tahu people. The Te Rūnanga o Ngāi Tahu has a number of policies, strategies and initiatives that speak to Ngāi Tahu tribal development, as well as revitalizing and nurturing Ngāi Tahu tribal identity. The vision of Te Rūnanga o Ngāi Tahu is encapsulated in the saying: 'Mō Tātou, $\bar{a}$, Mō Kà uri $\bar{a}$ muri ake nei-For us and our children after us. ${ }^{70}$

The Te Rūnanga o Ngāi Tahu is the legal entity and governing body or body corporate for Ngāi Tahu that replaced the old Ngāi Tahu Māori Trust Board when the Te Rūnanga o Ngāi Tahu Act was passed in 1996. There were a number of misgivings with respect to the old legal body with a major reason being that it had to report directly to the Minister of Māori Affairs in a paternalistic fashion and it really had no accountability back to its people. ${ }^{71}$

It was the intention of the early Ngāi Tahu Māori Trust Board that the investments for Ngāi Tahu should be aimed at securing those important cultural foundations within Te Waipounamu. Tipene O'Regan specifically noted the importance of mahinga kai and the geographical landscape when he said:

\footnotetext{
69 Piri Sciascia, personal interview $15^{\text {th }}$ August 2011.

70 Te Rūnanga o Ngāi Tahu Website - http://www.Ngāi Tahu.iwi.nz/About-Ngāi-Tahu/.Accessed on $6^{\text {th }}$ June 2012.

71 Solomon, 2006, 210.
} 
From the earliest days of the Trust Board there was a strong and ever-present view that investments should seek to secure and confirm the tribe's 'rohe pōtae' - creating an enduring tribal footprint grounded in Ngāi Tahu's cultural and geographical landscape and return the tribe to a position of authority and influence in the Te Waipounamu community. There was a parallel desire to establish greater tribal influence and control over natural resource-related matters, as well as a desire to effect restoration of degraded mahinga kai. ${ }^{72}$

According to O'Regan, the financial engine was always a core objective that would last in perpetuity and provide for the tribe's inter-generational needs. This financial basis would also maximize the non-financial redress provisions, such as the recognition of mana for mahinga kai and Department of Conservation (DOC) estates, including the ownership and management of pounamu. ${ }^{73}$

In the early days of the Ngāi Tahu Trust Board, as Tipene O'Regan noted, there was a strong and ever-present view that the investments should seek to secure and confirm the tribe's 'rohe pōtae' to create an enduring tribal footprint grounded in Ngāi Tahu's cultural and geographical landscape and that Ngāi Tahu should return to a position of authority and influence in the Te Waipounamu community. ${ }^{74} \mathrm{O}$ 'Regan speaks about the emerging tribal development philosophy of Ngāi Tahu in the "establishment of a dedicated financial engine that would seed capital on which the tribe could grow and sustain its future. The financial engine was to be the mechanism with which to realize Ngāi Tahu's long-term financial, cultural and social development goals." ${ }^{, 75}$ For O'Regan, the whakataukī, 'Mō Tātou, $\bar{a}$, Mō Kā uri à muri ake nei - For us and our children' guides Ngāi Tahu's intergenerational investment thinking and decision-making. ${ }^{76}$

The Te Rūnanga o Ngāi Tahu has a strong function in working on behalf of its people. The new phase of development for Te Rūnanga o Ngāi Tahu has many exciting pathways of development, notwithstanding the four pillars for Ngāi Tahu economic development: 1. Property, 2. Fisheries, 3.Tourism and 4.Equity. ${ }^{77}$ Ngāi Tahu Holdings Incorporated manages the commercial activities and assets of the tribe and, as noted in the Te Rūnanga o Ngāi Tahu Annual Report 2011, the "executive functions of Te Rūnanga o Ngāi Tahu are carried out by

72 O'Regan, 2008, 3. Tipene O'Regan speaking at the Māori Business Symposium: 'Intergenerational Wealth 'Re-igniting Indigenous Economies “Muramura ahi ka ki uta, Muramura ahi ki tai” in 2008.

73 Ibid. 3.

74 O'Regan, 2008, 3.

75 O'Regan, 2008. 2.

76 O'Regan mentioned the Whai Rawa investment scheme that started on 1October 2006 as a way that Ngāi Tahu could develop long term wealth for 1 . Tertiary education, 2. First home purchase and 3. Retirement.

77 Solomon, 2006. 
the Office of Te Rūnanga o Ngāi Tahu, which manages the representational activities, protects the rights of Ngāi Tahu Whānui and delivers social and cultural programmes.",78

However, what is important with the new legal structure is the acknowledgement of those of the past who helped the cause and the responsibility to care for the future generations. The inter-generational emphasis that recognizes past lives and their sacrifices for the present and future is an integral and important responsibility of Te Rūnanga o Ngāi Tahu. As Solomon says:

At the forefront of any decision made, past lives and future generations are remembered. If it were not for the efforts of others who have passed on in earlier years, Te Rūnanga o Ngāi Tahu (TRONT) would not be serving their people today. We have a responsibility to ensure that our taonga are handed down generation to generation. So for the likes of myself, we are simply cogs in a wheel that attempts to improve the situation for our descendants. We are constantly reminded of this by which the Rūnanga live by: 'Mō Tātou, $\bar{a}$, Mō Kā uri à muri ake nei' (For us and our children after us). ${ }^{79}$

Te Rūnanga o Ngāi Tahu is now in a strong position to deliver real benefits to its people as once dreamed and imagined by Ngāi Tahu leaders in the past. The Ngāi Tahu Fund is set up for cultural rejuvenation and to provide resources for whānau and hapū to assist in the development of initiatives that promote and grow Ngāi Tahutanga. In 2010-11 the Ngāi Tahu Fund distributed \$703,324 in support of 71 Ngāi Tahu cultural projects and this was reduced by $\$ 150,000$ in support of the Christchurch Earthquake response. ${ }^{80}$ In the Ngāi Tahu 2025 distribution chart in the Ngāi Tahu Annual Report 2011, 7 percent is also set aside for Tō Tātou Ngāi Tahutanga. This broad fund covers whakapapa, te reo initiatives and those things that express Ngāi Tahu identity. ${ }^{81}$

Ngāi Tahu is a big corporate player in New Zealand and their success has been the result of great tenacity and termination, often in the face of great adversity and challenge. As Tom Bennion noted: "What speaks of overwhelming success is the fact the iwi no longer sits in the corner of our national picture. It's front and centre, a big corporate player holding a large chunk of the nation's natural resources." 82 However, the success of its commerce has meant tensions in its balancing with its tribal culture. For example, for many, the Ngāi Tahu claim

8 Ngāi Tahu Annual Report 2011.

79 Solomon, 2006, 210.

80 Ngāi Tahu Annual Report 2011, 8 .

81 Ibid. 7-8.

${ }^{82}$ Te Karaka Magazine, Issue 40, 2008, p.35. 
provided the means by which the tribe could once again affirm its rangatiratanga or selfdetermination, yet by going through that process they in themselves created a corporate structure that was shaped by their identity formation. ${ }^{83}$

As Smith and Ruckstuhl say: "The Treaty settlement may have restored some of the 'substance' of Ngāi Tahu culture destroyed by the process of colonization, yet it is also a process that required Ngāi Tahu to shape their identity in corporate terms. As the iwi knows, the fine balance between corporate structures and tribal values must be constantly adjusted, weighed and debated." ${ }^{\prime 84}$

The transformation of Ngāi Tahu into a major economic player has not been without the knowledge of the value of culture for its peoples. As Tipene O'Regan says: "it's always the intergenerational thinking and decision-making processes that reinforce cultural concepts like Kaitiakitanga and whakatipuranga." 85 The concept of corporate social responsibility is well embedded in Ngāi Tahu's approach to development. O'Regan, in his address to the Māori Business Symposium 'Muramura Ahi Kā ki Uta, Muramura Ahi Kā ki Tai' in 2008, stated that the concept of corporate social responsibility actually acknowledges and reinforces our concepts of kaitiakitanga and whakatipuranga and that Ngāi Tahu have instinctively behaved in ways that honour their tikanga. ${ }^{86}$

Tipene O'Regan described the symbolism of the wharenui for the core principles of the 'House of Tahu' during the early stages of the claim and their tribal organization. The wharenui symbol was the image and covenant for Ngāi Tahu and this was important as it clearly showed the place of culture, commerce and tino rangatiratanga for the tribe. The adoption of taonga to symbolize their unification as an iwi shows a deep understanding and recognition of taonga in contemporary Ngāi Tahu society. There were two pou tahu; one for the social and cultural benefits, while the other represented the commercial interests. The poutokomanawa represents the tino rangatiratanga, the tahuhu represents the whakapapa that unifies the iwi and the poupou depict the traditional runaka marae with the tukutuku weaving them together. ${ }^{87}$

Ibid. 33-34.

84 Smith and Ruckstuhl, 2010, 35.

85 O'Regan, 2008.

86 O'Regan, 2008, 11.

87 Diamond, 2003, 42. 
There are many initiatives that the Ngāi Tahu corporate entity undertakes for the betterment of Ngāi Tahu people; however, what is presented here is merely a selection of some of the projects that have relevance to this research. The language revitalization strategy 'Kotahi Mano Kāika, Kotahi Mano Wawata' (One thousand homes, One thousand aspirations) was launched by Te Rūnanga o Ngāi Tahu in 2002. This macro-tribal language strategy was initiated because Ngāi Tahu's language health was one of the worst in New Zealand. ${ }^{88}$ The Ngāi Tahu vision was to establish 1000 Ngāi Tahu homes speaking te reo by $2020 .{ }^{89}$ O'Regan noted in 2009, however, that although 3500 individuals had registered on the programme, less than 200 actively engaged in their own language development. ${ }^{90}$ This project indicates the important place that te reo has for Ngāi Tahu for their present and future generations.

Two other projects worth noting are the Aoraki Bound programme and the Ngāi Tahu Hui-āTau. Both of these are organized by Te Rūnanga o Ngāi Tahu and both reflect strong support for nurturing and developing Ngāi Tahutanga. The Aoraki Bound programme is a 20-day, journey-based course that helps to build leadership, cultural understanding and personal development. The purpose of Aoraki Bound centres on cultural revitalization and for Mark Solomon (Chairman of Te Rūnanga o Ngāi Tahu), "The value of Aoraki Bound will be realized by the differences it makes to the next generation in terms of the revival and perpetuation of Ngāi Tahu culture, knowledge and identity, and the development of our people as future leaders." 91 The Ngāi Tahu Hui-ā-Tau 2012 held at the Lincoln Events Centre included in its three-day programme a number of cultural activities, including kapa haka, wānanga, exhibitions and arts workshops. The importance of Ngāi Tahu culture and identity is clearly a major foundation for the tribe, as are the values of whanaungatanga, manaakitanga and kaitiakitanga.

Some of the strongest expressions of Ngāi Tahu identity can be seen through the history of the Ngāi Tahu Waitangi claim, along with the myriad activities supported by the Te Rūnanga o Ngāi Tahu. When asked what constitutes Ngāi Tahu identity, Tipene O'Regan noted the centrality of whakapapa and the importance of place. O'Regan also said that Ngāi Tahu identity is one that is moving from the claim to a post-claim form and that taonga configure

88 O’Regan, 2006, 161.

89 Ibid. The 25-year language strategy was based on the language planning theory of the world-renowned language revitalization expert Professor Joshua Fishman (p.161).

90 O’Regan, 2009, 82.

91 Aoraki Bound - http://www.Ngāitahu.iwi.nz/Ngāi-Tahu-Whanui/Aoraki-Bound/. Accessed on October 10 2011. 
into this new Ngāi Tahu identity as the form is synonymous with place and place is a central element of whakapapa. This point is a major one for Ngāi Tahu as the claim was so strongly aligned to Ngāi Tahu identity and for O'Regan the unique taonga associated with particular places are the core of Ngāi Tahu identity:

That was an interesting question because for some five generations identity has been synonymous with the claim, since 1849 . And one of our great challenges was to go into the post-Te Kerēme phase. So the issue of new composition and new design was really quite important. What we were replicating was ... standard version of Māori design. The composition of new waiata, the composition of new things and the whole idea that if you haven't got them then you're going to have to write them. You're going to have to make them. We're going to have to build them. If I was asked what was the core of that identity it has really been place and a few particularly treasured forms. I think the evolution of rei puta in its different forms, chevron amulets as Skinner called them. And the pounamu version of this. The taumutu hei matau. Which has appeared on all sorts of forms? The little triangular fish from Murihiku, superb little piece. So many of us wear today because we know it's the oldest thing of pounamu we know about in terms of provenance. Those design characteristics are all pretty unique to Ngāi Tahu. So for us I think, the form is synonymous with place and place is a central element of whakapapa. So I think Ngāi Tahu identity is moving from that claim think into that post-claim form. ${ }^{92}$

Other culture-related initiatives that Ngāi Tahu undertook include the Ngāi Tahu

Development Corporation's waiata compilations, 'Te Hā o Tahupōtiki', a collection of waiata unique to Ngāi Tahu whānui, and two waiata tapes titled 'Haea te ata' and 'Te Akaraupo'. These compilations were accompanied by booklets dedicated to providing material relevant to Ngāi Tahu, as support for Ngāi Tahu kaikōrero or speakers on their paepae. The words of the Te Hā o Tahupōtiki noted: "Ngāi Tahu Development Corporation is committed to the development of Kaitahutaka. Waiata is a powerful bonding activity that can bring Kāi Tahu Whānui together to show strength of identity and solidarity. These are your taoka, they are our taoka, treasure them, nurture them and protect them." ${ }^{.93}$ These resources demonstrate a strong commitment to the development of Ngāi Tahu culture.

There are many shared characteristics that shape Ngāi Tahu tribal identity. Hana O'Regan presents Ngāi Tahu identity as a constantly shifting relational category and for her "identity is about feeling, belief and perception. It is, about one's consciousness and sub-consciousness, one's relationships and interactions, one's experience within the world." ${ }^{94}$ The importance of whakapapa and the land is well expressed by O'Regan when she says: “A Kāi Tahu identity provides a sense of belonging. Through whakapapa, you are connected to the land. That

92 Tipene O’Regan interview, October 2011.

93 Te Hā o Tahupōtiki booklet (1998:5).

94 O’Regan, 2001, 27. 
connection is confirmed and reinforced by the ancestral histories, place names, urupā and personal experiences in Te Waipounamu. Being Kāi Tahu means having an established tūrakawaewae, belonging to place and community." 95

\section{Te Puāwai o Ngāi Tahu exhibition}

The Te Puāwai o Ngāi Tahu Exhibition showcased and promoted twelve Ngāi Tahu artists to reveal the excellence and diversity of Ngāi Tahu visual culture. This exhibition was held at the Christchurch Art Gallery Te Puna o Waiwhetu from 10 ${ }^{\text {th }}$ May 2003 to $24^{\text {th }}$ August 2003. Some of the artists included Cath Brown, Neil Pardington, Areta Wilkinson and Ross Hemera, all of Ngāi Tahu ancestry. In the foreword to the booklet published for the exhibition, the Kaiwhakahaere of Ngāi Tahu, Mark Solomon, noted how the title of the exhibition is interpreted as blossoming, flowering and generating in relation to Ngāi Tahu visual art and $12 \mathrm{Ngāi}$ Tahu contemporary artists. ${ }^{96}$ He further noted how the inclusion of Ngāi Tahu taonga from the Canterbury Museum and the New Zealand Film Archive acknowledged the history of the site (i.e. Te Puna o Waiwhetu) and "the broader cultural context to which the artists are linked through whakapapa."97

The Puāwai o Ngāi Tahu Exhibition was an exhibition that coincided with the opening of the Christchurch Art Gallery. The exhibition heralded the significance of Ngāi Tahu art and artists and, like Megan Tamati-Quennell's comments regarding the Mō Tātou Ngāi Tahu Whānui Exhibition, it also signaled the value that Ngāi Tahu place on culture, as Jonathan Mane-Wheoki reminds us:

With the settlement of their Treaty claim in 1998, the careful management of their natural and financial resources, the extraordinary success of their business ventures (Whale Watch at Kaikoura, for instance), effective leadership making them one of the most powerful economic forces in Te Wai Pounamu, and the value they place on culture and education, the iwi can be said to have entered a new golden age. ${ }^{98}$

Fiona Pardington, one of the artists in the exhibition and of Kāi Tahu, Kāti Mamoe, and Kāti Waewae, believes that some objects speak to the heart of Ngāi Tahu material culture and the power of taonga. For Pardington it is the "imminence of the tipuna of the Ngāi Tahu

95 Ibid. 165.

96 'Te Puāwai o Ngāi Tahu: Twelve Contemporary Ngāi Tahu Artists' exhibition catalogue, 2003, 5.

97 Ibid. 6. The Director of the Christchurch Art Gallery said the historical artefacts acted as an entry point to the exhibition and "a most appropriate introduction to classical Ngāi Tahu cultural concepts."

98 Mane-Wheoki, Jonathan. 2003. “A New Flowering of Ngāi Tahu Art/Toi o Ngāi Tahu: He Puāwaiwaitanga Hou”. In Te Puāwai o Ngāi Tahu: Twelve Contemporary Ngāi Tahu Artists, edited by Anna Rogers, 18-33. Cristchurch: Spectrum Print Ltd. 32. 
taonga." ${ }^{99}$ For Ross Hemera the 'Omarama - Plentiful light' watercolour drew inspiration from the unique culture and landscape of North Otago and the ancient rock art drawings found in limestone caves.

\title{
Ngāi Tahu Pouwhenua - Project Hikina taku mana
}

\author{
Hikina taku mana \\ Poupōua ki te whenua \\ Taku mana tupuna \\ Taku mana takata \\ Taku pouwhenua e $!^{100}$
}

The Ngāi Tahu Pouwhenua Project was created to raise the profile and enhance the mana of Ngāi Tahu through a process of commissioning art projects. The project is also a good example of the relationship between Ngāi Tahu economic development and Ngāi Tahu cultural development, as the driver for this project is about securing the significance of the land and cultural meanings. The Ngāi Tahu Pouwhenua Project is associated with the Ngāi Tahu Property directorate and as noted in the Ngāi Tahu Properties Newsletter: "The Pouwhenua Project is a re-visioning of tradition, signalling a reinvestment of iwi identity, pride and spirit into the land, ensuring the footprint of our commerce resonates the footprint of our culture."101

The Pouwhenua Project uses senior artists to record the whakapapa of the land and to acknowledge the rich histories of the cultural landscape. The first marker of the Pouwhenua Project was the Queenstown Post Office Precinct and the Ngāi Tahu artist Ross Hemera used the story of Hakitekura to provide inspiration for iconic design elements that were uniquely Ngāi Tahu. This project is a good example of the relationship between Ngāi Tahu identity and development through the agency of taonga, as it demonstrates and affirms the central role that Ngāi Tahu contemporary taonga play in today's contemporary world with regard to Ngāi Tahu identity. Nowhere is this more evident than through Ngāi Tahu tribal members when speaking about the Pouwhenua Project.

99 See 'Te Puāwai o Ngāi Tahu: Twelve Contemporary Ngāi Tahu Artists' catalogue, 2003, 64. Original reference is Fiona Pardington, Te Mate o Te Aroha/The Pain of Longing, 2002, unpaginated.

100 These words featured at the start of an article about the Ngāi Tahu Pouwhenua Project published by Te Rūnanga o Ngāi Tahu in 1996. The words speak about the importance of the land and ancestors.

101 Ngāi Tahu Property website - http://Ngāi Tahuproperty.co.nz/pouwhenua-projects/. Accessed on $20^{\text {th }}$ September 2012. 
The Pouwhenua Project involved senior Ngāi Tahu artists who guided the precinct's design team. Artists like Rachel Rakena, Ross Hemera and Fayne Robinson met with the local rūnaka and presented plans to the Ngāi Tahu Property Group. For Fayne Robinson the pouwhenua is about learning the whakapapa of the region and identifying ourselves: "We've got a beautiful history, so it's time Ngāi Tahu was seen as well as heard."102 The comments of Ngāi Tahu artists in respect to the Pouwhenua Project are of value to this research because they provide insider artist perspectives:

- "One of the most sensible and admirable things we could do on behalf of the iwi."

- $\quad$ "The ways in which we express ourselves while referencing the past is actually a treasure we need to continue to develop, and to go on expressing in current ways."104

- "It's actually an honour to have the opportunity to have your work part of really an expression of the iwi of Ngāi Tahu aspirations, about who and what they are ... I just feel as though that I am just adding my layer on top of what has been handed down to me and so I'm honoured to be able to give visual form to our Ngāi Tahu heritage." 105

The importance of the land to Ngāi Tahu history and identity was similarly expressed in 2005 when the Te Rūnanga o Ngāi Tahu commissioned the 'Pepeha in the City' programme to bring traditional Māori sayings to the fore of the Christchurch community. ${ }^{106}$

\section{9th Venice Biennale of Art - Pounamu Kaitahu}

The $49^{\text {th }}$ Venice Biennale of Art in 2001 was another kaupapa that involved Ngāi Tahu. This prestigious international art event included two prominent Ngāi Tahu artists, Jacqueline Frazer and Peter Robinson. This was a significant kaupapa for New Zealand as the artists had to have a high profile in New Zealand as well as overseas. Having two Ngāi Tahu artists in the Venice Biennale was a great honour for Ngāi Tahu and, to mark the significance of this, Ngāi Tahu sent a Māori performing arts group or kapa haka group called 'Pounamu Kāi Tahu'. This group was sent to honour the two Ngāi Tahu artists and to launch their artworks at the Piazetta di San Marco.

\footnotetext{
102 Ibid.

103 Liesl Johnstone article titled 'Marks of an ancestor' in Te Karaka Magazine Issue 44, 2009.

104 Ibid.

105 Ibid: See video on the artworks of the Queenstown Post Office Precinct - http://www.tekaraka.co.nz/TeKaraka-44/MarksOfAnAncestor/Video.php. Accessed on 10th September 2011.

106 Ibid. 416. Gerard O'Regan mentions one of the traditional sayings, 'Ka pakihi whakatekateka a Waitaha' (The plains where Waitaha strutted proudly) where the rock art kiwi-embryo figure was used to promote it.
} 
For Ngāi Tahu the occasion was hugely significant in both recognition of the Ngāi Tahu artists selected, as well as the tribe itself with respect to their arts portfolio. ${ }^{107}$ In the publication titled ‘Te Puāwai o Ngāi Tahu: Twelve Contemporary Ngāi Tahu Artists' edited by Anna Rogers on behalf of the Christchurch Art Gallery Te Puna o Waiwhetu, they used the title ‘A New Flowering of Ngāi Tahu Art/Toi o Ngāi Tahu: He Puāwaitanga Hou' for their article on the Venice Biennale. ${ }^{108}$ Ngāi Tahu's appearance on this international art stage made a huge impact as images were splashed across newspapers and on television screens. ${ }^{109}$ The article also noted how the history of art-making stretched back 1000 years, citing excellent examples of art from carvers from Waitaha, Ngāti Mamoe and Ngāi Tahu. ${ }^{110}$

This project is important for the research proposition as it signals the importance of Ngāi Tahu art for the tribe and its association with Ngāi Tahu histories. Having Ngāi Tahu art on the world stage could only be positive for the tribe and the positioning of their cultural futures. The Kaiwhakahaere of Te Rūnanga o Ngāi Tahu, Mark Solomon, had this to say: "Our two visual artists operate in a very contemporary world. However, they also carry with them the wairua (spirit) and history of Ngāi Tahu, which is demonstrated in another medium by the group of performing artists Pounamu Kāi Tahu," Mr Solomon said. "In a Māori context the group are the Korowai (spiritual cloak), and the guardians of the work and the visual artists themselves."111

\section{Te Ana Ngāi Tahu Māori Rock Art Centre}

The Te Ana Ngāi Tahu Māori Rock Art Centre was a Ngāi Tahu tribal initiative which is a \$2.6 million interactive facility housed in an historic building in Timaru. ${ }^{112}$ The Te Ana Ngāi Tahu Māori Rock Art Centre opened in December 2010 and represented the culmination of years of planning and hard work. Mark Solomon made the statement that "the opening of the Te Ana Ngāi Tahu Rock Art Centre in Timaru was an incredible occasion for the iwi and particularly the Ngāi Tahu Māori Rock Art Trust. Te Rūnanga extends its congratulations to

\footnotetext{
107 Interestingly, both Ngāi Tahu artists prefer to be seen as international artists who live and work abroad rather than just 'Māori' artists (McCarthy, 2011: 238).

1082003.

109 Ibid. 18.

110 Ibid.

111 Creative New Zealand Press Release dated 30 ${ }^{\text {th }}$ April 2001.

112 McCarthy, 2011, 240.
} 
those that devoted their tireless dedication and effort to realising this dream."113 Solomon further expressed the following sentiments: "The centre is hugely significant for Ngāi Tahu.

It is the culmination of years of hard work and devotion to protecting and preserving this important cultural and historical taonga for the iwi and now we have the perfect showcase for sharing it with the world."

The Ngāi Tahu Rock Art Centre was developed by the people for the people as Gerard O'Regan, one of the founders of the kaupapa, noted: "There's a lot of enthusiasm for the project because of the tribal statement it makes. It's an iwi-developed and driven kaupapa."115 The significance of the Māori Rock Art Centre for Ngāi Tahu is clearly evident as it is one of the first things you see when you enter the website of Te Rūnanga o Ngāi Tahu and it has become an identifiable symbol and marker of Ngāi Tahu identity.

An interesting comment by O'Regan that has relevance to this thesis is the proposition on how Ngāi Tahu heritage sites, such as the rock art, have increasing relevance to expressions of Ngāi Tahu identity. O'Regan also notes the importance of place to the Ngāi Tahu rock art and that Ngāi Tahu Māori knew about them and added to them with images of European people, sailing ships and scripts. ${ }^{116}$ The relationship of Ngāi Tahu rock art with Ngāi Tahu identity is particularly pertinent to this research, because by extension taonga have similar dimensions with respect to whakapapa relationships, cultural knowledge and values, and history. Carter reminds us of the significance of Ngāi Tahu rock art and provides a way of understanding why it serves as an identity symbol for Ngāi Tahu. Arguably, this is the same for other Ngāi Tahu taonga.

For most Ngāi Tahu, the images do not need to be viewed in their original location in order to sustain identity and understand the cultural values retained by them. For the majority of Ngāi Tahu, the images are identity symbols which serve to recall relationships. They may not have

\footnotetext{
113 Ngāi Tahu Annual Report, 2011 p.8.

114 See Timaru Herald, 2 December 2010. http://www.stuff.co.nz/timaru-herald/news/4413069/Art-centre-toshowcase-iwis-toanga. Accessed on November 12th 2011.

115 Ibid.

116 Ibid. 413.
} 
seen the images in the original landscape context, but still the images serve as powerful identity symbols which encapture he cultural value, recall the traditions and portray the whakapapa relationships. ${ }^{117}$

Perhaps, however, the most notable and visible expression of Ngāi Tahu rock art's relationship with Ngāi Tahu identity can be seen by the fact that the 'kiwi embryo' Ngāi Tahu rock art image has been used on meeting houses at Rehua marae, Christchurch, Aoraki at the Ngā Hau e Whā marae, Christchurch, and the contemporary mural on the wall at the whare Uenuku, North Otago. The use of the rock art image in these wharenui is strong evidence that support my research proposition that Ngāi Tahu taonga do have a role to play with regard to Ngāi Tahu identity and development. O'Regan goes as far as to say that the "Te Rūnanga o Moeraki, the Māori community there, considers itself the guardian of the area in which the kiwi embryo was recorded and its use in that instance is as a marker of local identity." 118

Further to this, O'Regan notes how this identity has extended to other areas: "This expression of tribal pride exhibited through the rock-art imagery has extended to its incorporation in body art in the current tā moko (tattooing) renaissance." ${ }^{119}$ The Ngāi Tahu artist Ross Hemera often uses rock art references to examine and express ideas of identity, significance and the relationships between land and culture. ${ }^{120}$ In his commission for the Queenstown Post Office, Hemera recalls that: "It's actually an honour to have the opportunity to have your work part of really an expression of the iwi of Ngāi Tahu aspirations about who and what they are. ...so I'm honoured to be able to give visual form to our Ngāi Tahu heritage."121

\section{Mō Tätou, ā, Mo kā uri ā muri ake nei exhibition}

The Ngāi Tahu Whānui Iwi exhibition 'Mō Tātou, ā, Mo kā uri ā muri ake nei' (Mō Tātou) provides a good case study example of the relationship between Ngāi Tahu tribal taonga and Ngāi Tahu tribal identity and development through the agency of their tribal taonga. $M \bar{o}$ Tãtou was the fifth iwi or Māori tribal exhibition at the Museum of New Zealand Te Papa

\footnotetext{
117 Carter, 2010, 177. Lyn Carter cites the quote given by an elder from the Northern tribe to describe symbols of identity. "The physical presence [of the image] recalls the name. The name recalls the event. The event recalls the whakapapa. The whakapapa recalls the connection between things past and things present. The connection between things past and things present is the element, which gives... pride and identity."

118 Ibid. 414.

119 Ibid. 416. Gerard O'Regan says how the tā moko is inked into the arms of the Kamo family of Christchurch.

${ }^{120}$ Hemara created the Te Ao Marama tomokanga at the entrance to the Mana Whenua Exhibition on level 4 of the Museum of New Zealand Te Papa Tongarewa in 1998. The references to Ngāi Tahu rock art are central to many of his commissions and artworks.

121 Te Rūnanga o Ngāi Tahu, 1996.
} 
Tongarewa (Te Papa). The iwi exhibition programme started at Te Papa in 1998 when the new national museum opened its doors to the public on the Wellington waterfront. ${ }^{122}$

Although Ngāi Tahu is well known for their stellar economic success and corporate savviness, Mō Tātou was one of those kaupapa that elevated Ngāi Tahu's success in a cultural way. Mō Tātou celebrated Ngāi Tahu history, culture and identity in ways that moved thousands of people from the early morning dawn ceremony held at Te Papa, to engaging and reconnecting with Ngāi Tahu people in the regions of the South Island, on its homecoming tour Te Hokinga Mai.

Mō Tâtou opened at Te Papa on $8^{\text {th }}$ July 2006 and closed on $9^{\text {th }}$ August 2009. Following on from its success at Te Papa, Mō Tātou then started its homecoming tour travelling to the Christchurch Museum (20 $0^{\text {th }}$ February-20 ${ }^{\text {th }}$ June 2010), Southland Art Gallery \& Museum $\left(10^{\text {th }}\right.$ July $-14^{\text {th }}$ November 2010$)$ and then on to the Otago Museum $\left(4^{\text {th }}\right.$ December $2010-3^{\text {rd }}$ April 2011). Like the opening ceremony at Te Papa, the closing ceremony at the Otago Museum was charged with high emotion and celebration, notwithstanding the tears that were shed by those many Ngāi Tahu tribal members present. The journey from Te Papa to its home venues was recounted with pride and affection by both young and old. Mō Tātou celebrated the history and achievements of the tribe, including Ngāi Tahu values and their future visions and aspirations.

The significance of $M \bar{o}$ Tãtou is clearly evident when you consider the reaction and feedback from Ngāi Tahu people while it was on display from 2006 to 2011. The Ngāi Tahu Annual Report 2010 included a large number of images of Mó Tātou and the accompanying Mo Kā Uri exhibition organized for the homecoming tour of the exhibition. The images show young and old celebrating their Ngāi Tahutanga and their language. The Ngāi Tahu Annual Report 2011 also made the comment that Mō Tātou "proved its worth as the premier showcase of Ngāi Tahu taonga, histories, stories and culture."

Mō Tãtou not only celebrated important moments in Ngāi Tahu's past history but, equally important, a strong focus on the future and developmental aspirations of the tribe. Perhaps no stronger was this articulated than through the title of the exhibition itself 'Mō Tātou, ā, Mō kāa

122 The first iwi exhibition was the local tribe Te Atiawa (Feb 1998-Aug 1999) followed by the Te Aupouri Iwi: People of Smoke and Flame (Aug 1999-Oct 2001); Tūhoe: Children of the Mist (Nov 2001-Nov 2003); Te Awa Tupua: The Whanganui Iwi (Nov 2003-May 2006); Mō Tātou: The Ngāi Tahu Whānui exhibition (July 2006-July 2009). The present iwi exhibition is Tai Timu, Tai Pari: Tainui Journey of a People of Tainui /Waikato (2011-2014). 
uri ā muri ake nei'- For us and the generations to follow. Throughout the exhibition tour these words resonated from those in governance positions, to the leaders of Ngāi Tahu, and down to its people on the ground. The opening of Mō Tâtou at Te Papa along with its closing ceremony included the continual repetition of these words by Ngāi Tahu speakers. For Mark Solomon, the Kaiwhakahaere of Te Rūnanga o Ngāi Tahu, Mō Tãtou was a great journey full of pride: "A journey that started at Te Papa. What has it done? It has taught us about ourselves. It has taught the rest of the nation about us. It has been a beautiful experience. It is a bit sad [that it is coming to an end]. It is the biggest expression of Ngāi Tahu. It has been a beautiful journey ... I am absolutely proud of the numbers from all over the country. It made you proud to see our people, made you proud when you walked through our exhibition and said: 'Look, that's my taonga.", 123

The words and concepts that were created by the Ngāi Tahu Iwi Steering Group for the exhibition provide further evidence of who Ngāi Tahu people are and what is important to them. The four cultural values that were drawn from the tribal saying, 'Mó tātou, $\bar{a}, m \bar{o} k \bar{a} u r i$ $\bar{a}$ muri ake nei'- For us and our children after us, clearly show the contemporary importance of the past and the affirmation that tenacity and culture were organizing principles for the future of Ngāi Tahu. The position of taonga is clearly enunciated, as is the distinct and dynamic culture of Ngāi Tahu with its representation of art on the world stage.

The following is how Mō Tātou was promoted at Te Papa and the Māori and English words convey strong messages regarding Ngāi Tahu's understanding and relationship with the past, present and future. The use of the word 'toitū' is important because this translates as 'enduring'. The inclusion of Culture along with Tenacity, Sustainability and Innovation, represents the importance of the past, such as the tenacity of the claim, as it does for the future where innovation is just as important.

The Mō Tātou: The Ngāi Tahu Whānui Exhibition at the Museum of New Zealand Te Papa Tongarewa declared that the people of the South Island invite you to celebrate our past and present, learn about our values, and share our vision for the future in this, the fifth iwi exhibition at Te Papa...

Ngāi Tahu means 'people of Tahu' after our founder, Tahu Pōtiki. Around ten generations ago, his descendants migrated from the North Island of New Zealand to the South Island. Through intermarriage and conquest, these original migrants merged with the resident Waitaha and Kāti Māmoe tribes, to form Ngāi Tahu Whānui as it is today...

${ }^{123}$ Te Karaka Magazine issue 50, July 2011. 
Embedded in the land, Ngāi Tahu Whānui have survived and progressed from neardecimation to tribal autonomy and self-reliance. Four cultural values, drawn from the tribal saying 'Mō tātou, $\bar{a}$, mō kā uri $\bar{a}$ muri ake nei. For us and our children after us', are the organising principles for this exhibition and reflect our contemporary understanding of our past and our future. They are:

- Toitū te iwi - Culture

- Toitū te Rangatiratanga - Tenacity

- Toitū te ao tūroa - Sustainability

- Toitū te pae tawhiti - Innovation

From our creation story to our most important taonga (treasures), to our representation on the world art stage, Mō Tãtou celebrates the distinct and dynamic culture of the South Island's Ngāi Tahu people.

Mó Tàtou actively involved the Ngāi Tahu people right from the start, from the initial meetings between Te Papa and Ngāi Tahu right through to its planning, design, interpretation and layout. Megan Tamati-Quennell, the curator and iwi exhibition concept developer and herself Ngāi Tahu, "wanted to make sure that it was not a classical social history narrative, 'who we are', 'what we are'; I wanted to use a different curatorial model. I wanted to talk about us as a people historically, but also in modernity and ensure our present was acknowledged and seen as important, that there was not only a focus on our past."124

As Alivizatou notes: "The Mō Tâtou exhibition also paid tribute to the historical moments that changed the tribe, the political struggles including the settlement of Te Kerēme, their land claim; grievances that highlighted breaches of the Treaty of Waitangi; and the Crown apology that formed part of the claim settlement. The exhibition was also accompanied by an audiovisual explaining the claim history and claim settlement. Overall, Ngāi Tahu emerge as a vibrant and dynamic tribe with strong roots in tradition, but well informed and engaged in contemporary economic, political, and cultural affairs."125

In a poignant way Tamati-Quennell made the statement that Ngāi Tahu were not only an economic powerhouse, but equally were a strong cultural force: "I think the exhibition at Te Papa made people outside of Ngāi Tahu realise that the tribe is not just an economic force... but that we are also a cultural force."126 The Chairman of the Iwi Steering Group, Charles Crofts, also supported this view, elevating its taonga and artistic heritage: "The (Ngāi Tahu) claim put us in the national headlines, especially in economic terms. But Mō Tâtou put a

\footnotetext{
124 Alivizatou, Marilena. 2012. "From Artefacts to Communities: Participation and Contestation at Te Papa Tongarewa." In Intangible Heritage and the Museum: New Perspectives on Cultural Preservation, edited by Marilena Alivizatou, 49-76. California: Walnut Creek: Left Coast Press. 60-61. 125 Ibid.

126 Te Karaka Magazine, issue 44, 2009.
} 
national spotlight on us as an iwi with taonga and an artistic heritage. It also presented a stage for our contemporary artists to show their work." ${ }^{\prime 27}$ Crofts also noted how the exhibition solidified relations between museums and iwi. ${ }^{128}$

For Tamati-Quennell: "It is all about how you want to represent yourself. The exhibition was a representation of our history and culture as we understand it today. We (myself and the Iwi Steering Group) decided against focusing on our history of pre-European tribal warfare including the Kai Huaka feud which was a battle which in English translates as 'eat relations'; we did not talk about the severe impact of colonisation on the tribe apart from the focus on Te Kerēme - our land grievance claim and claim settlement. Instead we wanted to present our people as the backbone of the tribe and talk about the unique aspects of culture specific to us, unique within Māori and within the world; of our achievement, of us as a tribe with strong cultural anchors but of our future aspirations, where we are looking to in the future." 129

Alivizatou argues Mō Tâtou presented people as the backbone of the tribe and handed over a whole section of the exhibition to the hapu or sub-tribes for them to select treasured taonga. These taonga along with their kōrero were to represent their identities within the larger tribal ethos of Ngāi Tahu. ${ }^{130}$ In acknowledging how Ngāi Tahu had settled their claim with respect to the importance of the whenua and their people, Ngāi Tahu also wanted an emphasis on the connection of people and place in Mō Tâtou. This was readily seen with the selection of taonga with their accompanying text and graphics. Pepeha or tribal sayings were also used to "present oral mapping and naming of landscape and whakapapa (genealogy) to reinforce a sense of belonging and the tribe's ties to land and place."131

According to McCarthy, Mō Tätou differed from other iwi exhibitions in that it was an eclectic blend of history, culture and development with a mix of different kinds of visual art, such as customary carving and craft, including politicized modernists and syncretic postmodernists. The exhibition differed from the other iwi exhibitions at Te Papa in that "this one was more creative in reflecting the post-settlement experience of a tribe who had already

\footnotetext{
127 Ibid.

128 Ibid.

129 Ibid.

130 Ibid. 61.

131 Ibid.
} 
settled their claim and embarked on economic and cultural development." ${ }^{\text {"132 }}$ McCarthy further notes that commentators observed that this gave the exhibition a radical edge missing from previous exhibitions. ${ }^{133}$

Perhaps most visibly was the coming together and celebration of Ngāi Tahutanga through $M \bar{o}$ Tãtou. Its impact and legacy was significant and as Ana Sciascia so poignantly says: "Te Hapa o Niu Tireni is a Ngāi Tahu meeting house in Temuka, South Canterbury. Its name means the grievances of New Zealand, or the broken promise, in reference to the longpursued Treaty claim of Ngāi Tahu, Te Kerēme. If Te Hapa o Niu Tireni is a symbol of Ngāi Tahu's past Treaty grievance, then Mō Tàtou is a proclamation of our cultural renaissance and future aspirations, as stated in the exhibition themes: Toitū te iwi, Toitū te Rangatiratanga, Toitū te ao turoa, Toitū te pae tawhiti!",134

Mō Tãtou had a deep impact on Ngāi Tahu people if we look at the visitor research carried out on the exhibition: "Findings from the survey show that $90 \%$ of respondents visited $M \bar{o}$ Tãtou, while $83 \%$ of respondents reported that the exhibition generated new cultural aspirations. The principal motivation to visit Mō Tätou was 'to learn and reconnect' to their Ngāi Tahutanga." ${ }^{135}$ In addition to this, an astounding 84 percent of respondents either strongly agreed or agreed that Mō Tãtou enhanced their Ngāi Tahu identity. ${ }^{136}$

The Te Hokinga Mai or return home journey was deemed vital for Ngāi Tahu so that the exhibition could reconnect back to their hapū areas. The Te Hokinga Mai of Mō Tâtou reaffirmed the importance of place and taonga to the Ngāi Tahu people. It reaffirmed their identities and gave renewed pride in their history and the tipuna of the past. As the exhibition travelled to Christchurch, Southland and Otago it was hosted by the papatipu rūnaka who provided their own additions to the parent exhibition.

The Mō Kă Uri component of Te Hokinga Mai at the Canterbury Museum included the tipuna room where photographs of named and many unnamed tipuna created spiritual

\footnotetext{
132 McCarthy, 2011, 137-8.

133 Ibid.

134 Sciascia, Ana. 2011. Iwi Exhibitions at Te Papa: A Ngāi Tahu Perspective. MA, Museum and Heritage Studies, Victoria University of Wellington, Wellington.

135 Ibid. Abstract iii.

136 Ibid. 36.
} 
meaning, connections and enduring relationships. The article on the closing of Mó Tãtou as reported in the Ngāi Tahu iwi magazine Te Karaka ${ }^{137}$ summed up the importance of this exhibition to the many Ngāi Tahu people.

The touring phase of the Mō Tätou exhibition provided another level for Ngāi Tahu members to articulate and express their Ngāi Tahutanga. For Mark Solomon, the relationship with the taonga connected the past with the present: “As I walk among these ancestral artefacts and contemporary artworks, I am reminded I am part of something bigger, connected through whakapapa bloodlines to the taonga before me."138 For Kukupa Tirikatene, the Ngāi Tahu taonga brought the people together and allowed the renewal of kaitiakitanga. ${ }^{139}$

Through the eyes and hearts of its leaders and people we can better appreciate the significance of Mō Tãtou to Ngāi Tahu. With this we can consider the research question that seeks to understand the complexities of the politics of Ngāi Tahu tribal identity and development. For Puamiria Parata-Goodall, "Ngāi Tahu were engaging with their identity as hapū and as rūnanga and that the return home to the 'home' regions was like repatriating knowledge as for many Ngāi Tahu people it was their first entry point and reconnection into Ngāi Tahutanga. Puamiria acknowledged the reconnections back home to their regions and said: "recognising I'm not just Tahu, I'm Irakehu or Mako or I'm Kuri, and that not all Tahus are the same because we come from different strands and we understand things at different levels."

Keeping the Ngāi Tahu taonga warm and looking after them was an important dimension of kaitiakitanga as the taonga were the tipuna, as Puamiria Parata-Goodall says:

Working with touring the exhibition we saw the opportunity for our whānau to truly engage with our taonga and what that means to us as an iwi. There was a lot of work about manaaki ... they're not just things; they're your tipuna so you keep this place warm. Yes this is a museum but in this context our tipuna are here, koira whakamahana te whare and manaaki your taonga, your tipuna. It also brought a personal presence, that living face to the exhibition, he kanohi kitea. ${ }^{141}$

\footnotetext{
137 See Issue 50, July 2011.

138 See Mark Solomon article in the publication 'Te Hokinga Mai: Featuring Mō Tātou: The Ngāi Tahu Whānui Exhibition from Te Papa and Mō Kã Uri from Canterbury Museum’, 2010. Published by the Press Canterbury (unpaginated).

139 Sciascia, 2011, 55.

140 Sciascia, 2011, 60.

141 Cited in Sciascia, 2011, 55.
} 
The Southland Museum and Art Gallery (Niho o te Taniwha) manager Gael Ramsay said that Mō Tâtou created a lot of interest in the community: "The thing that stood out for me was the interaction from the local rūnanga.” Murihiku rūnanga members brought photographs of their tūpuna to the museum to show in $M \bar{o} N g \bar{a} U r i$, a contemporary exhibition that ran alongside Mō Tātou. Rūnanga members were also available to tell stories to visitors in the exhibition. "It was such a connecting point. They would look at the images, they would find their families. The whole thing had a spiritual meaning, it was beautiful." ${ }^{\prime 142}$

Likened to the highly renowned Māori exhibition, Te Māori, which travelled to four large museums in the United States in 1984, Mō Tâtou ended its journey at the Otago Museum on $17^{\text {th }}$ April 2011. What started with an early morning dawn ceremony at the Museum of New Zealand Te Papa Tongarewa with well over 1000 Ngāi Tahu people on July $8^{\text {th }} 2006$ ended with emotional tears, memories and great pride and celebration of Ngāi Tahutanga. The speeches made reference to founding ancestors, such as Tahu Potiki, and those ancestors who had led the claim, such as Matiaha Te Tiramorehu. The relationship of the past to the present was given by Piri Sciascia and Charlie Crofts along with the resilience and tenacity of Ngāi Tahu in the quest for self-determination. Well over one million people viewed Mō Tâtou and for the toua or elder maruhaeremuri it achieved its goal of enrichening the sense of heritage of Ngāi Tahu people and, in particular, the children. ${ }^{143}$

At the Otago Museum a fifth section had been created titled 'Aukaha kia kaha - Strengthen the bindings'. This was dedicated to the local context and involved the collaboration of five rūnaka - Waihao, Moeraki, Puketeraki, Ōtakou and Hokonui. This local section included photographs of the local settlements and history, along with large-scale marae photographs by Neil Pardington. ${ }^{144}$ For the Chairman of the Otago Museum's Māori Advisory Committee, Matapura Ellison: "This unique taonga and stories from each of the five rūnaka featured in Aukaha Kia Kaha serve to further enrich, from a local perspective, the core elements embodied within Mō Tätou." 145

In relation to the objects or Ngāi Tahu taonga in the exhibition, it would be more than fair to say that Ngāi Tahu saw themselves and their identity through an understanding of the

\footnotetext{
${ }^{142}$ Te Karaka Magazine, issue 50, July 2011.

143 Ibid.

144 Otago Museum website on the Mō Tãtou - The Ngāi Tahu Whānui Exhibition, accessed on $25^{\text {th }}$ January 2011.

145 Otago Museum Newsletter, Summer, Issue 91, 2010.
} 
meaning of the taonga. Ngāi Tahu's reality was similar to that advocated by Poole when he says: "It is the process by which members of the culture come to understand the meaning of the objects which form the culture and, crucially, find their identity in these objects."146

The taonga in the Mō Tãtou exhibition were important markers and symbols of Ngāi Tahu identity and, irrespective of the passing of time, they continue to act as powerful symbols of Ngāi Tahu identity or Ngāi Tahutanga going forward into the future. A survey conducted with Ngāi Tahu members in 2010-11 showed that the principal motivation to visit the Mō Tãtou exhibition was "to learn and reconnect" to their Ngāi Tahutanga. ${ }^{147}$ The survey affirmed the importance of Ngāi Tahu's cultural identity and as Sciascia says: "enabled a reconnection with taonga and cultural identity." "148 Ana Sciascia's important research on $M \bar{o}$ Tãtou shows how the exhibition was "used as an exemplary tool by Ngāi Tahu to advance the tribe's redevelopment of their cultural heritage and identity."

In an important way, Ngāi Tahu was seen in a new light other than that of its stellar economic performance. As Tamati-Quennell notes: "I think the exhibition at Te Papa made people outside of Ngāi Tahu realise that the tribe is not just an economic force, which is what we are often seen as through the settlement and investments; but that we are also a cultural force."149 Mō Tàtou was an exhibition that Ngāi Tahu was actively involved in, giving it authority, authorship and voice. Its impact was significant, as shown by the feedback of many of its tribal members, notwithstanding the museum fraternity who embraced it and celebrated its journey with its people. Mō Tâtou was a 'Critical Event' as its impact and legacy has been felt throughout Ngāi Tahu in ways that have and continue to shape Ngāi Tahu cultural futures thinking. 150

\section{Analysis and Discussion}

Five Ngāi Tahu people were interviewed, seeking their views on the Mō Tâtou exhibition, their tribal taonga, and what Ngāi Tahu identity and development meant to them. The people interviewed were Ngāi Tahu leaders and people actively involved in the development of the exhibition. The interviews were semi-structured with a list of questions carried out in a oneon-one kanohi ki te kanohi (face-to-face) interview approach. Some interviews were

\footnotetext{
146 Poole, 1999, 13.

147 Sciascia, 2011: Abstract III.

148 Sciascia, 2011, 68.

149 Sciascia, 2011, 63,65,66.

150 See Phillips, 2012.
} 
undertaken in their tribal regions while some were recorded at Te Papa. The interviews with tribal members are critical for this research as they are perspectives from people within the tribe who were actively involved in Mō Tätou. The interviews were sorted and grouped into themes that emerged from the research to show similarities, convergence and difference.

In addition to the interviews I also included documented sources and publications from a wide range of sources to supplement the views of the iwi tribal members. The first interview was with Megan Tamati-Quennell, the exhibition subject expert and curator. Megan was of Ngāi Tahu and had previously worked for Ngāi Tahu alongside Gerard O'Regan on their art and cultural development portfolio. For Megan, the role of working on Mō Tãtou was about responsibility and upholding the mana of Ngāi Tahu: "The responsibility of doing it on behalf of Ngāi Tahu people and I really wanted to uphold that mana. For me it was about upholding that mana and ensuring that we were presented in the best way possible and that it was something that they could be proud of."

The power of taonga was highly visible in Mō Tätou when one of the lenders of the taonga for the exhibition had lost family members before the exhibition opened. When the tribal member attended the opening, he saw the taonga and the association with his family was emotional and moving. As Tamati-Quennell recalls:

... and a third one was when one of the lenders to the show who had lost family cried at the opening seeing his mere pounamu because it was such a moving kind of association.

I love that whakatauki for us and our children after us ... for us and our children after us is an underpinning value because it's about us. Mō Tātou in simple terms was about my great grandmother and upholding things that she would have wanted me to uphold and it was about my son. And what he inherits and what he understands as himself in this world. ${ }^{151}$

Mó Tâtou is an example that speaks directly to the relationship between Ngāi Tahu taonga and the politics of Ngāi Tahu tribal identity and development. How the exhibition was created and organized, the Ngāi Tahu taonga selected, the positioning of Ngāi Tahu taonga in relation to Ngāi Tahu tribal development, and the impact and effect that the exhibition had on Ngāi Tahu people will show the relationship between Ngāi Tahu identity and development and the role Ngāi Tahu taonga play.

${ }^{151}$ Megan Tamati-Quennell interview, November 2012. 
For Megan Tamati-Quennell the claim became the assertion of Ngāi Tahu identity through its history of grievance and tenacity, but Mō Tātou placed Ngāi Tahu identity in a positive place that was grounded in culture:

I think it made a big contribution. You know to have two thousand people to turn up in the first place. It was something that people were rallying around. The last time we came together like that was around the claim which was also honourable but was part of the grievance. This was part of something much more positive. I think it put a stake in the ground. Culturally it was the first major survey of Ngāi Tahu art. It wasn't definitive, it wasn't exhaustive, it couldn't be our interpretation of our history you know it's what our history is all about, it's what our whakapapa is all about, shifts and changes. ${ }^{152}$

Mó Tâtou had a positive effect on the tribe as the key elements and themes of the exhibition were taken on board and adopted by the Ngāi Tahu Fund:

I think it was the culture and tenacity, basically those ideas were taken on board by the Ngāi Tahu fund as kind of a core key element of their strategy going forward: culture, sustainability, innovation, whakapapa I suppose comes into the culture those four things, whakapapa, culture, sustainability, innovation, were adopted by the tribe so they came directly out of the exhibition. ${ }^{153}$

Puamiria Parata-Goodall also reminds us of the pride that Mō Tātou brought to Ngāi Tahu and the role that taonga played in the assertion of Ngāi Tahutanga:

\begin{abstract}
A huge impact on me and on Ngāi Tahu whānau... the impact being all of a sudden this pride of - you know we just didn't turn up yesterday, actually we were here a really long time ago, our taonga tell us that, our taonga tell us the stories that we didn't necessarily know, nor did we recognize that these taonga could bring back all these memories, so a huge impact for us, a huge impact on our identity and our recognition and our questioning of ourselves, again that question of 'what is Tahutanga?'... So a huge impact in so far as learning about ourselves, learning about our own stories, learning about the connection between ourselves and some tangible connections between us and our past... we were bloody on to it! so the impact, the tangible, recordable, evidence of the impact are things like - turning up at the opening at Te Papa, and seeing so many of our Tahus there, completely unanticipated - thinking crap I have not seen so many Tahus in this one place before and I know all the Tahus I think - and that is that really tangible evidence of that whole iwi pride of we are not quite sure about our Tahuness or our connection but damn we have got this exhibition and damn I am turning up! ${ }^{154}$
\end{abstract}

For Piri Sciascia, the Deputy Chair of the Iwi Steering Group for Mō Tātou, the exhibition reminded him of the love and respect of his ancestors and the Te Mãori exhibition because of its success. ${ }^{155}$ Piri Sciascia futher said that: "and as far as Mō Tātou has been an awesome

\footnotetext{
152 Megan Tamati-Quennell interview, November 2012.

153 Megan Tamati-Quennell interview, November 2012.

154 Puamiria Parata-Goodall interview, October 2011.

155 Te Karaka Magazine, issue 50, July 2011. Published by Te Rūnanga o Ngāi Tahu.
} 
statement of Ngāi Tahu identity but as much as I loved 2000 Ngāi Tahu's turning up to the opening and closing and the beautiful time its magical time for the people was when it went home and those three venues and the little thing like of bringing those photo galleries by the time you got down to Murihiku but Christchurch had done it wonderfully gee this is wonderful, Murihiku much simpler... But that's the south it was a who's who of all the people." $" 156$

For Jane Davis, kaumātua of Oraka-Aparima the exhibition was a snapshot of Ngāi Tahu history and culture: "It's a reflection of the journey Ngāi Tahu has been on for hundreds of years ... Everyone who comes to it can relate to some part of it." 157 The agency and power of taonga to bring people together, interlacing whānau, was a dimension that Kukupa Tirikatene, one of the elders who represented Ngāi Tahu at Te Papa during the tenure of Mō Tātou, reflected upon:"The work that those taonga have done, they have interlaced whānau. Even neighbours who wouldn't normally talk to each other did. If nothing else, the exhibition has pulled people together.",158

Matapura Ellison, the Chairman of the Māori Advisory Committee to the Otago Museum, noted how important the exhibition was to Ngāi Tahu and in particular their identity: "Mō Tãtou represents a fantastic opportunity for Ngāi Tahu to reconnect directly with the taonga and the museums who hold them in safekeeping for our children and their children after them... Mō Tâtou is about showing our people their past, their present, their history and the steps taken forward in this day and age. In particular, I think it's about who we are."159

For Mark Solomon, Mō Tãtou was a visible link to the past that helped to define Ngāi Tahu people: "You only had to see it. I walked into Mō Tātou at Christchurch where they put up a lot of the old photographs and just watching whānau walk in and they just froze as they saw their tipuna sitting on the wall. We've got a very strong link to the past, and who we are, and I think that defines us. That link. You can be Ngāi Tahu in the modern context but unless you take the past with you, you forget all the real important lessons." Mō Tātou was special and

\footnotetext{
156 Piri Sciascia interview, August 2011.

157 See: The Southland Times article by Jared Morgan ‘A reflection of Ngāi Tahu's journey’ $12^{\text {th }}$ July 2010.

158 Te Karaka Magazine, issue 50, July 2011.

159 Te Karaka Magazine, issue 51, October 2011.
} 
deeply significant for Solomon. When asked what it has done, his reply was: "It has taught us about ourselves. It has taught the rest of the nation about us. It is the biggest expression of Ngāi Tahu; it has been a beautiful journey."160

For Maruhaeremuri Stirling, who was the tāua (elder), the exhibition was about the health of the people and looking after one another: "There have to be people there to keep an eye on things. We all have to be aware and we have to look after each other. It is for the health of our children. It is the people. We need to turn to each other and help each other and if people are struggling to learn te reo, give them a helping hand ... Events like Mó Tätou that promote people gathering together where there is a mixture of te reo and waiata, help to strengthen the reo and ensures a better future for the mokopuna." ${ }^{161}$ For Stirling, being one of two kaumātua or elders for Ngāi Tahu was "a way to honour her tribe and ancestors and to educate younger generations about Māori culture." 162

The title of the closing exhibition article in the Ngāi Tahu Te Karaka Journal, ${ }^{163}$ 'Enduring legacy', positions Mō Tãtou well. Here we see the power and influence of the exhibition in effecting change for the tribe. We also see that the themes of the exhibition resonated well with assertions of Ngāi Tahutanga, as they were later incorporated into the Ngāi Tahu Fund: "One developmental dimension of Mō Tãtou was that it strengthened the Ngāi Tahu Fund. This fund was shaped on Mō Tätou and the elders who were on the ISG [Iwi Steering Group] became its inaugural members. The fund has supported cultural knowledge, reo, and whakapapa, and has aligned itself with the four cultural themes of Mō Tātou: toitū te iwi (culture); toitū te Rangatiratanga (tenacity); toitū te ao tūroa (sustainability) and toitū te pae tawhiti (innovation).”

Mō Tàtou was transformational for Ngāi Tahu people from all walks of life. The impact of Mó Tàtou while at Te Papa and in the home regions indicated that Ngāi Tahu taonga are important to their tribal identity. Ngāi Tahu have a close affinity and intimate relationship with the land as a source of their identity and this is largely because the whenua represent the stories and the lives of the tipuna associated and commemorated with them. Ngāi Tahu taonga are symbolic of those important relationships and the mana of the ancestors and their lives. The relationship of the past to the present and the role that Ngāi Tahu taonga play with

\footnotetext{
160 Ibid.

161 Te Karaka Magazine, issue 50, July 2011.

162 Alivizatou, 2012, 67.

163 See Issue 50.
} 
respect to Ngāi Tahu identity and development is most aptly stated by Mark Solomon when he says: "We've got a very strong link to the past, and who we are, and I think that defines us. That link. You can be Ngāi Tahu in the modern context but unless you take the past with you, you forget all the real important lessons." 164

The relationship of Ngāi Tahu identity to its taonga is very intimate and strong as evidenced by Mō Tãtou and Ngāi Tahu projects, such as the Pouwhenua project. The feedback by iwi members and artists shows that Ngāi Tahu taonga are important symbols of identity, history and belonging. Mō Tātou with its Te Hokinga Mai return home involved Ngāi Tahu people and those of the rūnaka in ways that enriched and revitalised tribal and hapu identities. The relationship of the taonga with Ngāi Tahu identity and development is one of synergy and connected pathways. Each cannot proceed without the other.

Mō Tãtou has shown a direct relationship between Ngāi Tahu taonga and Ngāi Tahu cultural identity. The investigation of Mō Tãtou has revealed a strong conviction from tribal members that Ngāi Tahu taonga are important to Ngāi Tahu identity and history. The interviews with tribal members also indicate that Ngāi Tahu tribal development is closely aligned with the tribal proverb of caring for those now, along with the generations to come. The important research undertaken by Ana Sciascia ${ }^{165}$ affirms the importance of Ngāi Tahu taonga and their relationship with Ngāi Tahu cultural identity.

The Ngāi Tahu claim became the code word for resilience and tenacity and it was this resilience that asserted a strong Ngāi Tahu identity. From the resilience of the claim through to the present time, resilience is still being used as a core principle of Ngāi Tahu development. The claim has become a demonstrable assertion of contemporary Ngāi Tahu identity, as Hana O'Regan noted, ${ }^{166}$ but Tipene O'Regan asserts that Ngāi Tahu culture and identity must be explored as they move from the claim (grievance) to post-settlement. Tipene also believes that unique Ngāi Tahu taonga express the core of Ngāi Tahu identity. Taonga in this context become an assertion of contemporary Ngāi Tahu identity and development.

The metaphor of the greenstone door used by Hana O'Regan to describe the claim as a symbol of the past and a dream for a self-determining future is what the claim means to Ngāi

${ }^{164}$ Mark Solomon, personal interview, October 2011.

165 Sciascia 2011.

166 O'Regan, 2001, 147. O'Regan (2009) considers this claim asserted identity as valid but only in a temporary state. Her conviction is that Ngāi Tahu in the future state would have language as a core component of tribal identity (p.82). 
Tahu. ${ }^{167}$ Ngāi Tahu have increasingly used their taonga as part of their resilience and reassertion of their contemporary Ngāi Tahu identity. The claim represented tenacity, resilience and a determination to stand by the people, because it was about them and their future wellbeing. Ngāi Tahu have shown resilience and dedication in their claim journey and whakapapa has been a critical foundation of their past, present and future. Whakapapa for Ngāi Tahu has restored ancient and enduring relationships, reconnected cultural and spiritual taonga, brought whānau and kin together and provided a tribal renaissance to plan for a better future based on its relationship with the past and enduring Ngāi Tahu values and principles.

The claim is intimately associated with the Ngāi Tahu tribal authority. The prioritization of projects and initiatives as seen, for example, in the Ngāi Tahu Annual Report for 2011 is evidence of the importance of Ngāi Tahu heritage and taonga for Ngāi Tahu people. The Ngāi Tahu tribal authority allocates finances in support of Ngāi Tahutanga and the range of activities include exhibitions like Mō Tātou and artist and Ngāi Tahu taonga-related projects like the Pouwhenua project. These activities indicate the importance of Ngāi Tahu taonga to their cultural futures and ongoing development.

One can suggest that the claim was about becoming Ngāi Tahu in Hall's definition as much as it was about being Ngāi Tahu. Ngāi Tahu were transformed from a people that had lost large tracts of land and were forced to the periphery of their tribal whenua to a people that had their mahinga kai returned to them, geographical places renamed and the treasured pounamu returned to their kaitiaki. From poverty and harsh conditions, the grievance of the claim reasserted and transformed itself into a dynamic future that is economically, socially and culturally vibrant and based on a secure tribal identity.

The claim included the restoration of tino rangatiratanga to Ngāi Tahu, it returned the treasured pounamu or greenstone back to its people, and it included the inclusion of mahinga kai. Pounamu was located at the entrance to $M \bar{o} T \bar{a} t o u$ along with the narratives of its origins and traditions. As an 'enduring' treasure for Ngāi Tahu, its place within Ngāi Tahu as evidenced through the claim settlement, the Ngāi Tahu legislation and Mō Tātou attest to the importance of the relationship between taonga and Māori tribal identity. The development dimension is evidenced in the way Ngāi Tahu have adopted the Mō Tătou words to guide them into the future.

167 Ibid. 78,147. 
Like the metaphor of 'survivance', as adopted by Kylie Message, Ngāi Tahu have done what was necessary to keep their culture alive as part of their self-determination and selfrepresentation. Ngāi Tahu held on to ancient principles such as kaitiakitanga, mana tangata and mana whenua throughout the claim grievance and restitution, because they were embracing change but within a framework of tino rangatiratanga or self-determination. ${ }^{168}$ The restoration of Ngāi Tahu taonga is a tangible expression of what Simpson refers to as the resocialization of key items back to their living cultures. ${ }^{169}$ Simpson notes the link between heritage, health and wellbeing and for Ngāi Tahu this has been true for them. The claim provided the opportunity to restore key taonga of cultural and spiritual heritage back to Ngāi Tahu. The use of rock art images as markers of tribal identity and the creation of new taonga by contemporary Ngāi Tahu artists is an assertion of the resilience of taonga from the past for the present and future.

With regard to the research proposition of the role that Ngāi Tahu taonga play with respect to Ngāi Tahu identity and development, we need to look at the Te Rūnanga o Ngāi Tahu website and the section on cultural redress. One of the questions asked is how are things like wāhi tapu and mahinga kai relevant to Ngāi Tahu's development in the 1990s and beyond? The answer given is: "Ngāi Tahu's enduring relationship with its taonga and the environment is an integral part of our identity as an iwi. The passage of time makes this relationship no less relevant today than it was 150 years ago. The opportunities that the Cultural Redress package provides will allow tribal members to re-establish a relationship with the areas, resources and management philosophies that were important to our tipuna." ${ }^{170}$

The relationship between Ngāi Tahu identity and development in the operations of the tribal authority is about investing in the future wellbeing of its people and having a strong culture. This is highly visible in Ngāi Tahu's 25-year vision which sets a pathway that recognizes core values, such as whanaungatanga, manaakitanga and kaitiakitanga along with the vision for Tō Tātou Ngāi Tahutanga: "Our dream is to have a vibrant Ngāi Tahu culture. Our goal is that our taha wairua will flourish through the passion and energy we have to carry our culture forward." 171

\footnotetext{
168 Message, 2006, 1.

169 See Simpson, 2009.

170 Te Rūnanga o Ngāi Tahu Website (http://www.Ngāitahu.iwi.nz/About-Ngāi-Tahu/Settlement/SettlementOffer/Cultural-Redress/, accessed on 12 December 2012.

171 Ngāi Tahu Annual Report 2011, 3.
} 
Ngāi Tahu, through its tribal authority's policies and practices, have their eyes firmly on the contemporary development of their people, yet maintaining the values, relationships and connections to the past. Ngāi Tahu would perhaps endorse the sentiments of Sissons when he says that the recognition of indigeneity is and always has been about the future: "This appropriation, transformation and reappropriation of indigeneity - whether it be of objects, identity, children, land or sovereignty - only appears to be a circular process; in fact, it is linear, with each stage directed towards the future. Indigenous reappropriations represent futures redirected."172

For the cultural theorist Stuart Hall, cultural identity is not fixed or frozen but constantly being transformed and played out within the ongoing relationships of history, culture and power. For Hall, it is about who we are and where we belong as it is about becoming and being. ${ }^{173}$ Ngāi Tahu's historical experience and lived reality can be seen within Hall's definitions of identity and cultural identity. For Ngāi Tahu, their sense of belonging and identity has been tied up with both history and modernity with the journey of the claim and all its historical manifestations. This has extended through to Te Rūnanga o Ngāi Tahu and its mission to advance the people of Kāi Tahu economically, culturally and spiritually into the future.

Ngāi Tahu tribal identity has many dimensions and manifestations. For Hana O'Regan, Ngāi Tahu identity is expressed in the journey of the evolution of cultural identity: Toitū te reo May the language be permanent, Toitū te Maramataka - May we achieve enlightenment, Toitū te iwi - May our tribe survive. ${ }^{174}$ All of the Ngāi Tahu respondent interviews for this doctoral research noted that Ngāi Tahu taonga were an important expression of Ngāi Tahu identity and that Ngāi Tahu taonga were an equally important dimension of Ngāi Tahu development going forward into the future. Sir Tipene O'Regan and Mark Solomon, through their interviews and writings, strongly endorsed the corporate responsibility to look after their Ngāi Tahu people economically, socially and culturally. They both reaffirmed the importance of their whakataukī or proverb, 'Mō Tàtou, ā, Mō Kä Uri à muri ake nei' - For us and for our children after us, as the guiding ethos for inter-generational tribal health and wellbeing.

\footnotetext{
172 Sissons, 2005, 11. Sissons further says that, "Indigenism is the taking back of these things, a reclaiming, not of past lives, but of the present conditions for future lives within post-settler states. The processes of colonial appropriation and indigenous repossession are always also transformations" (p.140).

173 Hall, 1997, 3,225.

174 Words cited by Hana O'Regan as she reflects on her journey and aspirations for Kāi Tahu tribal identity. See O'Regan, Hana. "Toitū Te Iwi - a Journey in the Evolution of Cultural Identity." Te Kaharoa 2, (2009): 7788.
} 
What makes Ngāi Tahu identity are those relationships that have been stated and reiterated by Ngāi Tahu tribal members for well over 150 years, as noted by Hana O'Regan. She said that there were many common elements of that identity, such as whakapapa and relationship to land, the mahika kai traditions, the taoka found throughout our rohe, the claim and the political struggle that we have inherited from our tuppuna, the struggle with the language and with those whom we share our rohe, our legal identity, our names: "these are some of the things which have made us, and which continue to make us, Kāi Tahu today."175

If we applied Ngāi Tahu's experience to Paulin's Māori development framework, we would find favourable outcomes in all areas. The financial and cultural redress provisions have in large part enabled Ngāi Tahu to regain control over their traditional tribal lands and resources. Ngāi Tahu have developed an asset base that is being used to promote educational, cultural and social outcomes for their people and by becoming economically self-sufficient Ngāi Tahu are improving the socioeconomic circumstances of their people, as well as strengthening their cultural foundations. ${ }^{176}$ Adopting Paulin's s ${ }^{177}$ Māori development framework it was shown that Ngāi Tahu do develop long-term sustainability to provide financial resources for the educational, social and cultural development of their people. Most definitely Ngāi Tahu also preserved and actively strengthened their Ngāi Tahutanga as a part of their economic self-sufficiency.

The importance of the cultural and social development goals as noted by Tipene O'Regan was also a dimension expressed by Shane Jones when writing about Māori society and development: "Given the primacy accorded to culture and its central importance in defining the modern identity of Māori, it is not surprising that there has been a growing interest in revitalizing the identity and the operational capacity of the tribes." ${ }^{\prime 17}$ This view was also shared by Paul White, the CEO of Ngāi Tahu Development Corporation, in 2000 when he said that the Ngāi Tahu Development Corporation was about pathways along a continuum to tino rangatiratanga and that "without a firm and long-term focus on culture and identity, Ngāi Tahu will not exist in the future. It is fundamental to all development." ${ }^{179}$

\footnotetext{
175 O’Regan, 2001, 31

176 Paulin, 2005, 205.

177 Paulin, 2005.

178 Jones, 2006.

179 White, 2000, 43.
} 
For Mark Solomon, the Ngāi Tahu tribal proverb has become the guiding philosophy for Ngāi Tahu and the importance of inter-generational planning: "I think you can sum up our tribal identity in the whakatauki coined by our elders in the 1880 s and our elders in the $1870 \mathrm{~s}$ 'Mō Tãtou, à, mo kā uri à muri ake nei.' It was coined and it was around the claim that it was for them and their children after them and in a sense it's become the guiding philosophy with Ngāi Tahu since then and everything we do to look out how will it affect our grandchildren. And in a sense it's become the ethos of the tribe. It's always about us and our kids after us and I love it. I think it's an awesome whakataukī to stand by. It's simple."

\section{Conclusion}

It is very clear and demonstrable how the whakataukī, 'Mō Tātou, $\bar{a}, M \bar{o}$ Kà uri a muri ake $n e i$ ' - For us and our children after us, has a deep and significant meaning for Ngāi Tahu in their tribal inter-generational thinking, planning and decision-making process. The tribal saying is used by Te Rūnanga o Ngāi Tahu as its guiding ethos on vision statements, annual reports and it is reflected in Ngāi Tahu media and communications. The words are emblazoned on the Ngāi Tahu Annual Reports, the tribal authority website, and help guide the economic, social and cultural development projects for Ngāi Tahu. The tribal saying highlights the sustainable development aspirations of Ngāi Tahu and the requirement to ensure that the tribe does take account of the needs of this generation and those to come. The tribal proverb holds an enduring value that transcends space and time, and its relationship to identity and Ngāi Tahu development is guided by it and audited against it.

For Mark Solomon, the Ngāi Tahu tribal proverb has become the guiding philosophy for Ngāi Tahu and the importance of inter-generational planning: "I think you can sum up our tribal identity in the whakatauki coined by our elders in the $1880 \mathrm{~s}$ and our elders in the $1870 \mathrm{~s}$ 'Mō Tātou, $\bar{a}$, mo kā uri à muri ake nei.' It was coined and it was around the claim that it was for them and their children after them and in a sense it's become the guiding philosophy with Ngāi Tahu since then and everything we do to look out how will it affect our grandchildren.

${ }^{180}$ Mark Solomon interview, October 2011. Solomon said that the words 'Mō Tātou, ā, mō kā uri à muri ake $n e i$ ' were coined in the 1870s by the elders of the Ngāi Tahu Ngāti Mamoe Claim Census Committee. "They put it together and each successor body since then has carried it on. We formally adopted it as our guiding whakatauki." 
And in a sense it's become the ethos of the tribe. It's always about us and our kids after us and I love it. I think it's an awesome whakataukī to stand by. It's simple."181

A preview of the tribe's future development can reveal its commitment and relationship to its taonga and material culture. The sheer number of Ngāi Tahu taonga projects, exhibitions and artists' projects clearly reflect a relationship that is vital and important for Ngāi Tahu people. In the Ngāi Tahu Annual Report 2011, we see that the Ngāi Tahu Fund supported a wide range of projects in support of cultural rejuvenation. Ngāi Tahu distributed \$703,324 in support of 71 Ngāi Tahu cultural projects. The 'Ngāi Tahu 2025 Distribution' also states that 7 percent of funding will go towards Tō Tātou Ngāi Tahutanga (Culture and Identity). ${ }^{182}$

For Ngāi Tahu the politics of tribal identity align well with Durie's Te Pae Mahutonga model. The Mauriora dimension rests on a secure cultural identity which includes access to language and knowledge; access to culture and cultural institutions, such as marae; access to Māori economic resources, such as land, forests, fisheries; and access to social resources, such as whānau. For Ngāi Tahu, these Mauriora dimensions have played an important part in shaping constructions of Ngāi Tahu contemporary identity. Certainly the past is an important dimension of Ngāi Tahu contemporary society and the future development aspirations for Ngāi Tahu.

Durie's thoughts are very pertinent here when he says: "Cultures change and develop but in shaping a vision for the future the configuration of the past often provides a framework for reconfiguring that future." ${ }^{183}$ This is particularly true for the development aspirations of Ngāi Tahu into the future. Ngāi Tahu's claim became the code word for resilience and tenacity and these were at the heart of Ngāi Tahu in their assertion of Ngāi Tahu identity. The postsettlement phase of Ngāi Tahu has reasserted Ngāi Tahu identity where cultural dimensions, including language, tikanga, taonga and knowledge, contribute significantly to the centre.

\footnotetext{
${ }^{181}$ Mark Solomon interview, October 2011. Solomon said that the words 'Mō Tātou, à, mō kā uri à muri ake $n e i$ ' were coined in the 1870s by the elders of the Ngāi Tahu Ngāti Mamoe Claim Census Committee. "They put it together and each successor body since then has carried it on. We formally adopted it as our guiding whakatauki."

182 The 'Tō Tâtou Ngāi Tahutanga' portfolio includes whakapapa, the Ngāi Tahu Fund, Te Reo initiatives and Mō Tãtou.

183 Durie, 1998, 79.
} 


\section{Chapter Four: Kahungunu Ka Moe Ka Puta- The Politics of Ngāti Kahungunu Tribal Identity and Development}

\section{Introduction}

Chapter Three looked at the Ngāi Tahu tribe with regard to their tribal identity and development. An examination of their policies, practices and initiatives by looking at their tribal authority, treaty claim and range of cultural heritage projects shows a deep continuity with their historical past and a commitment to providing a sustainable future for their people in economic, social and cultural terms.

This chapter starts with a discussion of the origins and history of the Ngāti Kahungunu tribe to provide an historical context of the Ngāti Kahungunu people. This is important as the research question examines the complexities of the politics of Ngāti Kahungunu tribal identity and development. This is then followed by an examination of the Ngāti Kahungunu tribal authority 'Ngāti Kahungunu Iwi Inc.', along with their policies, practices and operations with regard to Ngāti Kahungunu culture and identity.

Ngāti Kahungunu has been chosen as a tribal case study as they have been actively engaged in a large number of art and cultural heritage projects over the last 40 years. Arguably, Ngāti Kahungunu has been involved in modernity and development initiatives for a long time with kaupapa, such as the Repudiation Movement ${ }^{1}$ in the 1870s and the Kotahitanga Māori Parliament in the 1890s and early 1900s, which advocated unity for Māori as a struggle for self-determination. This movement provided well-known tribal leaders and personalities on the national stage, such as Tamahau Mahupuku and Henare Tomoana. As Lyndsay Head says: "Ngāti Kahungunu were not blindly loyal to Pākehā neither were they moved by arguments of Māori nationalism. They were believers in modernity. Ngāti Kahungunu thought in collective terms and was anti-war as they saw fighting as a return to barbarism.",2

The tribal pepehā quoted at the start of this chapter 'Kahungunu Ka Moe, Ka Puta' refers to the many offspring of Kahungunu, the eponymous ancestor of Ngāti Kahungunu. Kahungunu had eight wives and formed strategic alliances with tribes throughout New Zealand. This proverb is often heard on marae throughout Aotearoa and was the title of a major Ngāti

1 The Repudiation Movement rejected land sales and was led by Ngāti Kahungunu leaders Henare Matua and Karaitiana Takamoana. The Te Wananga Māori newspaper was its main media of communication.

2 Head, Lyndsay. 2006. Land, Authority and the forgetting of being in early colonial history. PhD, Māori Studies, University of Canterbury, Christchurch. 229. 
Kahungunu exhibition in the 1990s. This chapter highlights how culture, reo and tikanga are at the forefront of Ngāti Kahungunu and how they are positioned as being the 'soul of the people'.

This chapter examines some of the more significant Ngāti Kahungunu taonga and art and cultural projects, including exhibitions such as the Nga Tukemata o Kahungunu exhibition at the Hawke's Bay Museum and Art Gallery (Napier Museum) that opened in 1986; the Nga Taonga o Tamatea exhibition held at the Waipukurau Civic Theatre in 1990; the Kahungunu Ka Moe Ka Puta exhibition that was shown in Hastings, Wellington, Masterton and Wairoa from 2000 to 2006; and a project undertaken by the National Library of New Zealand Te Puna Mātauranga o Aotearoa in partnership with Rangitāne and Ngāti Kahungunu-kiWairarapa of the Wairarapa rohe in 1997-8.

\section{Ngāti Kahungunu - origins}

Ngāti Kahungunu is a large tribe that is situated on the eastern seaboard of the North Island from Wairoa in Northern Hawke's Bay, through the alluvial plains of Heretaunga, down to the Wairarapa region. As stated earlier, Ngāti Kahungunu numbered close to 60,000tribal members in 2006 with a large proportion that live outside the tribal boundaries. The tribal boundaries are recognized as being from the Wharerata ranges in the Wairoa District, extending to Cape Palliser in South Wairarapa, while the coastal boundaries are from Paritu in the north to Turakirae in the south. ${ }^{3}$ Ngāti Kahungunu has the second largest tribal rohe in New Zealand and there are 86 marae administered by Ngāti Kahungunu Iwi Inc. ${ }^{4}$ These marae all represent strong declarations and markers of hapū identity. Ngāti Kahungunu is the third largest tribe in New Zealand with 59,946 tribal members in 2006, which account for 9\% of the total population of those with Māori descent. ${ }^{5}$

Like many tribal histories, there is an ever-burgeoning literature concerning the Ngāti Kahungunu tribe and its many hapū identities within the tribal region. Some of the more wellknown publications that pertain to the history of Ngāti Kahungunu include Tiaki Mitchell's Takitimu and Angela Ballara's PhD thesis The Origins of Ngāti Kahungunu (1991). Other important information includes the published online material in Te Ara: The Encyclopedia of

\footnotetext{
Ngāti Kahungunu Iwi Inc. website.

See Te Ao Marama, 2012: A Snapshot of Māori well-being, Statistics New Zealand.

See Statistics New Zealand, 2006.
} 
New Zealand and the historical information researched for Waitangi Tribunal claims. ${ }^{6}$ In addition to these are history meta-narratives, such as marae and wharenui histories, and school and church publications, which focus more on hapū and regional areas and as such accord a more detailed appreciation of the life and times of the peoples that make up the Ngāti Kahungunu tribe.

Ngāti Kahungunu is a large tribe formed principally from the union of the eponymous ancestor Kahungunu with the famed ancestress Rongomaiwahine of Mahia mai tawhiti. Kahungunu is renowned for his manliness and political astuteness as he formed strategic relationships with a number of tribes through eight strategic marriages. ${ }^{7}$ The marriage to Rongomaiwahine of Nukutaurua, Mahia produced many children who became important ancestral leaders and spheres of influence throughout the tribal lands. It is also through this marriage that we recognize other ancestral waka, such as the Kurahaupo canoe, the ancestral waka of the Mahia matriarch Rongomaiwahine.

The Takitimu waka is the ancestral voyaging canoe associated with the Ngāti Kahungunu tribe, while Tamatea Arikinui is the captain. The tohunga or ritual experts included Ruawharo who brought sand from Hawaiki and who established a whare wānanga on Portland Island, Mahia and Tūpai Whakarongo Wānanga. The Takitimu canoe is often recounted on marae throughout Aotearoa, and an important meeting house in Wairoa is named Takitimu to commemorate this Pacific ocean-going voyaging waka. ${ }^{8}$

There are many well-known hapu identities from Wairoa through to Hastings and down to the Wairarapa. Ngāti Kahungunu is, however, not the only tribe that reside in the tribal lands as Rangitāne reside in Tamaki nui-a-Rua (Dannevirke) and Wairarapa along with Ngāi Tahu from Mahia-Wairoa ${ }^{9}$ through to Central Hawke's Bay and the Wairarapa. These tribal identities have formed both the interlocking and interweaving relationships of Ngāti Kahungunu.

6 Examples include the Mohaka and Te Whanganui-a-Orutu Treaty claims.

7 Kahungunu married Hinetapu of Kaitaia; Te Hau Taruke of Opotiki; Ruarauhanga of Whangarā; Ruareretai of Popoia, Turanganui; Hinepūariari of Whareongaonga; Kahukurawaiaraia of Te Māhanga; Pouwharekura of Te Māhia and Rongomaiwahine of Nukutaurua (Simpson, Mīria, and Patrick Parsons. 2003. Ngā Taumata: A Portrait of Ngāti Kahungunu He Whakaahua o Ngāti Kahungunu 1870-1906. Wellington: Huia, Ngāti Kahungunu Iwi Incorporated, National Library of New Zealand. 58). See also Mitchell, 1972, 73.

8 The Takitimu waka journeyed south and, while resting at Waimārama, left one of its anchor stones or Taupunga there. The Taupunga marae in Waimārama is named after this occasion.

9 The Te Poho o Tahu meeting house in Mahia celebrates the ancestor Tahu Pōtiki of Ngāi Tahu and acknowledges the Takitimu waka. The hapū of this marae is Ngāti Matawhaiti (see Whaanga, Mere. 2003. "Telling our stories: Hapu identity in waiata, pakiwaitara and visual arts". In Māori and Oral History: a Collection, edited by Rachael Selby and Allison Laurie, 23-27. Palmerston North: Massey University.) 
Today, Ngāti Kahungunu is commonly identified as falling within three main regions - Ngāti Kahungunu-ki-Wairoa, Ngāti Kahungunu-ki-Heretaunga and Ngāti Kahungunu-kiWairarapa. These regions are often referred to when hui are held within Ngāti Kahungunu and outside the tribal lands to identify where the speaker is from. Ngāti Kahungunu as a tribal entity is believed to have surfaced in the early 1800 s in response to internecine warfare and changing social relations among hapū and communities. ${ }^{10}$ Ballara makes the distinction between corporate and conceptual groups as a way to understand iwi and hapū definitions. Ballara says that both groups are descent groups because they are kin and share descent from a common ancestor. Hapū were both corporate and conceptual groups as they were linked through descent and combined to act in defence and in the management of their own affairs. They were independently political and acknowledged no higher authority than their own chiefs.

Iwi, on the other hand, were conceptual groups in the eighteenth century and were wide categories of people who were descended from a common ancestor. Ballara says that they did not act in a corporate way at this time but, "In response to both internal and exotic influences, this situation changes from the late eighteenth century; the word 'iwi' took on, in some cases, a new, more restricted meaning as some iwi activated themselves as alternative, more inclusive corporate groups; these iwi or 'tribes' adapted themselves to become, in the twentieth century, the most recognised Māori descent groups."11

Maaka's research on the historical conception and perception of the tribe as a Māori political and social organization in the twentieth century is helpful in understanding the politics of Māori tribal identity. According to Maaka, the tribe has become a contested site as tribal leaders and government contested definitions and understandings. ${ }^{12}$ For Maaka, the tribe survived through the twentieth century because it remained relevant to Māori society. Initially, because it was continuity from the past, the tribal institution was the way that Māori society was conceived and organized. It retained its relevance because it remained central to Māori identity to the extent that it could be revitalized into new forms when the political

10 Ballara, 1991. Ballara gives the late eighteenth century as the time for the emergence of the modern Māori tribe of Ngāti Kahungunu (p. 502).

11 Ballara, Angela 1998. Iwi: The Dynamics of Māori Tribal Organisation from c.1769 to c.1945. Wellington: Victoria University Press. 336.

12 Maaka, 2003, 3. 
climate became suitable to tribalisation. By the end of the century, the tribe had become more relevant for Māori because it controlled access to substantial assets and political rights. ${ }^{13}$

Forming strategic relationships is an important dimension of Ngāti Kahungunu history.

Kahungunu married eight times as a way to establish strategic enduring relationships and some generations later the important Wairoa ancestor Te Huki ${ }^{14}$ settled his children throughout the tribal lands. This has become known as 'Te Kupenga a Te Huki' and the marriages throughout Ngāti Kahungunu were "to keep peace and unity among the people by marrying them into influential families." 15

More additional information of the Ngāti Kahungunu tribe is that one of its tribal members, James Carroll, was an acting Prime Minister for New Zealand, ${ }^{16}$ large areas of the tribal estate were alienated, ${ }^{17}$ and many Ngāti Kahungunu chiefs fought on the side of the Crown during the New Zealand wars in the 1860s. ${ }^{18}$ Ngāti Kahungunu also has the longest place name in the world near Porangahau in southern Hawke's Bay, Te

Taumatawhakatangihangakoauauotamateaturipukakapikimaungahoronuku pokaiwhenuakitanatahu, which translates as 'the hill on which Tamatea with his big knees who the country played his lament on his flute to the memory of his brother.'19

\section{Ngāti Kahungunu Iwi Incorporated - Pinepine te kura}

Ngāti Kahungunu Iwi Incorporated is the recognised tribal authority for the tribal people of Ngāti Kahungunu. Like the Ngāi Tahu tribal authority Te Rūnanga o Ngāi Tahu, the Ngāti Kahungunu Iwi Incorporated tribal authority is mandated to work for and on behalf of its people. By examining the Ngāti Kahungunu tribal authority and its strategies, policies and operations, we will glean a good understanding of its priorities and aspirations and the dimensions vital to Ngāti Kahungunu wellbeing. The Ngāti Kahungunu tribal authority

13 Ibid. 255.

14 Te Huki was a sixth-generation descendant of Kahungunu and Rongomaiwahine. Te Huki's three wives were Te Rangitohumare of Te Whatuiāpiti, Heretaunga, Hawke’s Bay; Te Ropuhina of Nūhaka; and Rewanga of Tūranganui.

15 See Simpson, et al. 2003, 37.

16 James Carroll became the acting Prime Minister in 1909 and 1911.

17 By 1859 it was estimated that 1,404,700 acres of land had been purchased by questionable means by the British Crown from Ngāti Kahungunu in Hawke's Bay. Only 3,000 to 4,000 acres of the ancestral estate remained for the Māori population of approximately 3,500. (Te Ara: The Encyclopedia of New Zealand 'Ngāti Kahungunu European Contact' (p.6.))

18 Many of the chiefs had to finance themselves and accrued large debts for assisting the Crown forces.

19 The name has 126 characters and Tamatea's son was Kahungunu, the eponymous ancestor of Ngāti Kahungunu. See Waitangi Tribunal,2011. Ko Aotearoa Tenei: A Report into Claims Concerning New Zealand Law and Policy Affecting Māori Culture and Identity. Wellington, Legislation Direct. 1. p.38. 
provides a good example of what is important to Ngāti Kahungunu and what constitutes the foundation or pillars of Ngāti Kahungunu tribal identity and development.

The history of the Ngāti Kahungunu Iwi Incorporation dates back to 1988 (19 ${ }^{\text {th }}$ December) when it was incorporated under the Incorporated Societies Act 1908 as Te Rūnanganui o Ngāti Kahungunu. With a brief period of political challenges, the tribal authority was reborn in 1996 ( $9^{\text {th }}$ December $)$ under the new name, Ngāti Kahungunu Iwi Incorporated. As noted on the Ngāti Kahungunu Iwi Inc. website, "a newly elected Board resumed control of Ngāti Kahungunu Iwi affairs in May 1997 and in 1998 the Board commissioned a team to undertake a constitutional review of Ngāti Kahungunu Iwi Incorporated." The report title was Ma Te Rango Te Waka Ka Rere and featured a large number of recommendations.

Roger Maaka provides a good account of the tribal development of Ngāti Kahungunu in the 1980s, along with the history of Te Rūnanganui o Ngāti Kahungunu. ${ }^{20}$ Maaka makes the argument that the retribalisation of Ngāti Kahungunu in the 1980s took the form of a centralized administration, the Rūnanga o Ngāti Kahungunu, and that this was spearheaded by highly respected profile personalities of Ngāti Kahungunu, as well as support by government policy. ${ }^{21}$ The Rūnanganui was divided into six taiwhenua or regional areas Wairoa, Te Whanganui-a-Orutu (Napier), Heretaunga (Hastings), Tamatea (Central Hawke's Bay), Tamakinui-a-rua (Dannevirke) and the Wairarapa. Maaka believes that the adoption of these six regions was flawed as the rūnanga wrongly assumed that Ngāti Kahungunu was a homogenous group with sovereignty over all the tribal territory, ignoring Ngāti Rongomaiwahine and Rangitāne. He believed that the traditional tribal rights of Ngāti Kahungunu would have centered on hapū and not regions. ${ }^{22}$

The Ngāti Kahungunu Iwi Incorporated tribal authority is mandated to represent the people of Ngāti Kahungunu and is the governing body for all aspects of Ngāti Kahungunu iwi development. The purpose of Ngāti Kahungunu Iwi Incorporated as communicated through its Annual Report for 2011-12 include the following:

- $\quad$ Promote or assist the education of Ngāti Kahungunu Iwi;

20 See Maaka, 2003

21 Ibid. 163. Maaka believes that this form of retribalisation was established on "some ill-defined and nebulous notion of tribal sovereignty" (p.163).

22 See Maaka, Roger, and Augie Fleras. 2005. The Politics of Indigeneity: Challenging the state in Canada and Aotearoa New Zealand: University of Otago Press.76. 
- $\quad$ Promote the custody and preservation of the beliefs, customs and language of Ngāti Kahungunu Iwi;

- $\quad$ Promote the social and economic welfare advancement and vocational training of Ngāti Kahungunu Iwi;

- $\quad$ Promote personal, whānau and community health and wellbeing and raise the living standards of Ngāti Kahungunu Iwi;

- $\quad$ Promote high quality communications to and for the benefit of the members of Ngāti Kahungunu Iwi. ${ }^{23}$

Ngāti Kahungunu has a strong vision and mission statement that demonstrably affirm Ngāti Kahungunutanga to the world. The Vision and Mission Statement of Ngāti Kahungunu Iwi Incorporated as outlined in the Ngāti Kahungunu Iwi Inc. Annual Report (2011-12) is worth noting here as the language adopted effectively communicates the uniqueness of Ngāti Kahungunu identity:

\section{Vision Statement}

$$
\begin{gathered}
\text { "Kahungunu - ki te whaiao, ki te ao mārama" } \\
\text { Achieving excellence in all areas of our lives }
\end{gathered}
$$

\section{Mission Statement}

"Kia maumahara ki te mana āhua ake o Ngāti Kahungunu" Uphold the absolute uniqueness of the living breath of Kahungunu

"To enhance the mana and well-being of Ngāti Kahungunu Iwi"

The commitment to and importance of art, culture and identity to Ngāti Kahungunu are communicated throughout the Ngāti Kahungunu corporate entity. The portfolio on 'Tikanga me Toi or Arts and Culture', for example, clearly and unequivocally proclaims the importance of arts and culture to Ngāti Kahungunu: "Retention of our cultural identity is paramount for it is the soul of the Iwi and it's what makes us unique. Our language, our art, our waiata, our stories, our history is all part of our cultural identity." 24

What we see with Ngāti Kahungunu are a number of strategies, policies and initiatives that aim to enhance the mana of Ngāti Kahungunu through language, tikanga and Ngāti

23 See Ngāti Kahungunu Iwi Incorporated Annual Report 2011-12.

24 Ngāti Kahungunu Iwi Inc. website. 
Kahungunu cultural expressions. The range of these initiatives recognizes the historical traditions of the past and the future aspirations of Ngāti Kahungunu and its peoples. It is not the intention of this research dissertation to provide a detailed account of all the initiatives that the Ngāti Kahungunu Iwi Incorporated tribal authority have undertaken or are undertaking. Rather, it is important and of relevance to the doctoral research question to glean a good understanding of the relationship of Ngāti Kahungunu taonga and material culture to Ngāti Kahungunu tribal identity and development through the operations of Ngāti Kahungunu Iwi Incorporated.

This research seeks to understand the relationship between Ngāti Kahungunu tribal identity and tribal development through the agency of Ngāti Kahungunu tribal taonga. What role, if any, do Ngāti Kahungunu taonga play with regard to Ngāti Kahungunu identity and development? An examination of the policies and practices of Ngāti Kahungunu clearly tells us that the cultural dimension plays an important role in the development of Ngāti Kahungunu. For the Chairman of the Ngāti Kahungunu tribal authority, the commercial must go hand in hand with the cultural dimension. Tomoana believes that there is a mutually beneficial relationship between the two and one that he describes as the 'cultural road to commerce': "for me, for Kahungunu, is about the arts, the business; the economic development cannot go without the cultural development." ${ }^{25}$ Tomoana recognizes the importance of culture to Ngāti Kahungunu when he identifies the arts, the reo and whakapapa as being critical dimensions of Ngāti Kahungunutanga both now and into the future:

\footnotetext{
We call it the cultural road to commerce and so we say that our underlying approach to the rest of the world is in our culture and that's arts and that's our reo and that's our whakapapa ... You've got to have them both ... We're not going to be the richest iwi in the world, we're not going to be the most tikanga-driven iwi in the world, but moving forward we are going to have a blend of both but the cultural our taonga are going to instruct how the anga whakamua will be." 26
}

For Meka Whaitiri, the Chief Executive Officer of Te Rūnanga o Ngāti Kahungunu, Ngāti Kahungunu identity lies at the hapū or sub-tribal level. She believes that the tribal identity stems from the hapū and through this relationship the whānau and marae tautoko this. Meka strongly believes that the reo and, in particular, the Kahungunu reo, is critical to Ngāti Kahungunu identity:

\footnotetext{
25 Ngahiwi Tomoana interview, September 2011.

26 Ibid.
} 
We are just made up of a whole lot of hapū and so for the iwi the identity stems from within the hapū ... So that's my understanding of tribal identity ... I think it starts again with the individual, within the individual whānau. So I think our identity is actually our reo, that's critical, that's something the rūnanga, particularly our Chairman, talks quite a lot about that we address all our social ills through our reo. ${ }^{27}$

Part of Ngāti Kahungunu's Iwi Development Portfolio is a 25 Year Vision and one of the seven strategic objectives is being 'culturally strong'. ${ }^{28}$ This is an important strategic objective as it outlines the range of activities that form Ngāti Kahungunu art, culture and identity. The following initiatives pertain to the Kahungunu 2026 'Culturally Strong' objective:

- Triennial Takitimu International Festivals

- $\quad$ Establishment of whare wānanga

- $\quad$ Takitimu history taught in all schools

- $\quad$ Te reo taught at all levels in all schools

- Inventory of whakairo, kōwhaiwhai, tukutuku, in all marae.

- Kahungunu publications; musical, theatrical and film productions.

- Kahungunu Cultural Centre with archives and contemporary development in the arts

- $\quad$ Kahungunu Sports Academy with Kahungunu teams in World Cup events

The Te Pae Huarewa - Kahungunu Cultural Standards Project is being led by Ngāti Kahungunu Iwi Incorporated. Underlying the project is the philosophy that Ngāti Kahungunu history and culture are an integral and important part of Ngāti Kahungunu teaching and learning. As noted by Ngāti Kahungunu, the educational aspirations of Ngāti Kahungunu people are no different from others and from a Māori point of view, Māori language and culture are important considerations in the education of Māori children and ultimately linked to issues of identity. ${ }^{29}$

The purpose of the Ngāti Kahungunu Cultural Standards Project is to focus on the importance of Ngāti Kahungnu tribal history and culture for the education of Ngāti Kahungunu people.

27 Meka Whaitiri interview, October 2011.

28 Other strategic objectives include: Economic strength; Participate as a contributing nation in the world; Tino rangātiratanga: Independence and self-determination; Environmental health and well-being; Culturally strong; Strong, vibrant, healthy whānau; and Making our mark. In 2006, the Board reviewed the first five years of the Vision and decided that the seven Strategic Objectives be grouped under four strategic planning themes of which one included 'Kahungunutanga: Cultural strength, making our mark, participating as a contributing nation in the world.'

29 Ngāti Kahungunu Iwi Inc. website. 
The symbol and cultural construct of a prestigious cloak, Te Tōpuni Tauwhainga, taken from the waiata oriori of Nohomaiterangi, was given as a metaphor for the project. The tribe says that: "Ngāti Kahungunu history and culture are an integral part of the teachings and learning's [sic] in Ngāti Kahungunu rohe. Early childhood and school settings should ensure Ngāti Kahungunu children enjoy educational success as Ngāti Kahungunu and as Māori.” ${ }^{30}$ Taking the cloak as the metaphor for the project shows the tribe's deep understanding of their taonga in modern times.

As part of Ngāti Kahungunu's forward development planning, Whaitiri champions the reclaiming dimension, as noted by Linda Smith. ${ }^{31}$ Whaitiri believes that reclaiming taonga back to the tribe is important: "I think one of the taonga pieces in terms of reclaiming it back to the rightful owners is probably: Knowing where they are and having the expertise at home to actually identify where they are because as we all know a lot of the Ngāti Kahungunu taonga aren't actually at home." ${ }^{32}$ Whaitiri also mentions the Ngāti Kahungunu waiata oriori 'Pinepine te kura' as an example that encapsulates the tribe's journey and pathways into the future: "There's a story in that waiata and I am pretty sure there are stories like that that our tipuna left for us to navigate the pathways and challenges of life. Pinepine te kura that's what it does for us, we bring it up, we go through it, we dissect it and it's there. So I am using that as a practical example of a waiata. There are many many more that have that but Pinepine for me just strikes a chord." 33

For Ngahiwi Tomoana, the cultural dimension is all-pervasive and important to the tribe, as being culturally educated and strong in Ngāti Kahungunutanga creates strong families, hapū and tribe. Tomoana adopts the words 'taku wahine purotu, taku tane purotu' as a tribal philosophy for his people in relation to the Kahungunu Cultural Standards project:

One more thing is that to do that we've got to use some of our standards and I used the term 'Taku wahine purotu, taku tane purotu'. We've got to make all our children, our teenagers, our parents taku wahine purotu taku tane purotu the most desirable Kahungunu people that could ever be and that's by filling them with te reo and education and comprehension and then let them go. They will be desired in the workplace, desired in romance, desired in politics, they'll be desired in culture, they will be desired by their

Ibid.

See Smith, L. 1999.

32 Meka Whaitiri interview, October 2011. Meka Whaitiri said how whakamā or embarrassed Ngāti Kahungunu had become when they travelled to the Kingitanga Coronation and sung only two verses of the waiata oriori 'Pinepine te kura' as opposed to other tribes like Ngāi Tūhoe who sung all verses of Ngāi Tūhoe's version of Pinepine te kura.

33 Ibid. 
own whānau, by their hapū, so that's when we know it's gone from iwi down to the mokopuna, taku wahine purotu, taku tane purotu ... cultural excellence is based again on the arts and the soul of the arts is te reo. ${ }^{34}$

Ngāti Kahungunu is presently embarking on a new vision for the creation of an Ngāti Kahungunu Cultural Centre with its inspiration taken from the Kahungunu, Ka Moe, Ka Puta exhibition. This cultural centre idea recognizes the importance of Kahungunu culture and identity to the future development of Ngāti Kahungunu. One of the key strategic goals for Ngāti Kahungunu Iwi Incorporated is to establish a cultural centre for the advancement and expression of Kahungunutanga. This centre will become a catalyst to develop and support programmes and projects that preserve, extend and promote cultural knowledge and practice for and between whānau through wānanga, exhibitions and festivals. ${ }^{35}$

\section{Ngā Tukemata o Kahungunu exhibition}

The Ngā Tukemata o Kahungunu exhibition opened at the Hawke's Bay Museum \& Art Gallery (Napier Museum) on $26^{\text {th }}$ July 1986 and closed on $25^{\text {th }}$ July 2010. The exhibition is significant for this research as it comprised many Ngāti Kahungunu taonga and celebrated Ngāti Kahungunu tribal history. The full title of the exhibition, Ngā Tukemata o Kahungunu; Treasures of Ngāti Kahungunu, is an identifiable Ngāti Kahungunu reference to the 'eyebrows' of the eponymous ancestor Kahungunu and a reference to his good looks. ${ }^{36}$ This title was given by the Ngāti Kahungunu kaumātua of the Advisory Group. ${ }^{37}$ A good account of Nga Tukemata o Kahungunu is given by two leading academics who have both worked in museums and lectured in museum studies courses at two universities. David Butts (1990), the curator of Ngā Tukemata o Kahungunu, and Dr Conal McCarthy (2011), a former employee of the National Museum of New Zealand and lecturer in Museum Studies at Victoria University of Wellington, will provide insightful views. These accounts are reflective and analytical and Butts' writing, in particular, is important because it provides insights from the

34 Ibid.

35 See 'Strategic Plan for the Revitalisation of te Reo o Ngāti Kahungunu 2006-2027' by Ngāti Kahungunu Iwi Inc. p.5. The report also noted how the Ngāti Kahungunu iwi Hauora Plan 2003-2005 highlighted te reo and tikanga as central to the tribe's wellbeing and the affirmation of Kahungunu identity (p.5).

36 Tribal tradition has it that Kahungunu only had to look at a woman and they would desire him. Mitchell (1944) says that the name was applied to the Wairoa chief Tapuwae and his wife Ruataumata and their descendants. The name refers to an historical incident when the grandparent of Tapuwae Kotore was killed by Apanui of the Bay of Plenty when he raided his pā Omaruhakeke. Kotore said Apanui was ugly before being killed and referred to his sons Umurau and Tamahikiwai as the broad, handsome face of Kahungunu (p.119).

37 Ibid. 47. Butts said that it was the elder John Tangiora who gave the title 'The Awakening' (Butts 1990). 
Ngāti Kahungunu people who were actively involved in the exhibition. A good summary and description is given on the Hawke's Bay Museum \& Art Gallery website under 'previous exhibitions'.

This exhibition is a celebration of the mana of Ngāti Kahungunu. It is an attempt to alert visitors to the mauri (the life essence), the ihi (the power) and the wehi (the awe) which Ngāti Kahungunu feel from their taonga (art). Taonga are addressed in whaikorero (speech-making) as the living past: Respect the taonga for what they are - a living and powerful dimension of the Ngāti Kahungunu culture. Ngā Tukemata o Kahungunu challenges each of us in different ways. For some, there will be the discovery of Ngāti Kahungunu as tangata whenua (indigenous people of the land). For some, there will be an awakening to Ngāti Kahungunu art as a tradition equal to any in the world. For Ngāti Kahungunu, this exhibition is a celebration of their tipuna (ancestors) and a reminder to the rest of us that they are still a strong people. ${ }^{38}$

This exhibition is important as it was opened during an active period of Māori exhibitions. Some of these include the highly successful Te Māori exhibition opened at the Metropolitan Museum of Art, New York, on $10^{\text {th }}$ September 1984 and closed in Auckland on its Te Hokinga Mai tour three years later. An exhibition of 'Seven Māori Artists', including Darcy Nicholas, Cliff Whiting, Fred Graham, Rangi Hetet, Erenora Puketapu-Hetet, Robyn Kahukiwa and Sandy Adsett, opened at the Sarjeant Gallery in Whanganui in 1985, after which it travelled overseas in 1986.

Ngā Tukemata o Kahungunu was conceived during a time when a number of provincial museums were undertaking developments to their Māori exhibitions. During and before that time, a Māori exhibition as Butts reminds us: "portrayed a Māori culture dislocated in time and space: a case of nephrite artefacts, a cast of cloaks, a case of wakahuia (feather boxes), a case of bone artefacts etc." 39 Butts goes as far as to say that "These exhibitions gave no indication that the Hawke's Bay Māoris had a tribal identity, and that the people who had occupied the area for some 1000 years had a rich history." 40

David Butts was the curator of the exhibition and, early in the exhibition's development, established an advisory group to guide the development of the exhibition. Important Ngāti

38 Hawke's Bay Museum \& Art Gallery website. Accessed on $10^{\text {th }}$ July 2011.

39 Butts, 1990, 109.

40 Ibid. 
Kahungunu kaumātua were part of this group, including Piri Sciascia, Boy Tomoana, John Tangiora, Canon Wi Huata and Heitia Hiha. ${ }^{41}$

The well-known Ngāti Kahungunu artist, Sandy Adsett, was the exhibition designer and the excellence of the exhibition design was noted when he received the Tourism Design Award in $1986 .{ }^{42}$ This group was important in the whole process, as the idea to have an exhibition about Ngāti Kahungunu came from them. Having Sandy Adsett as the artist/designer for the exhibition was important, as Butts says that he produced an exhibition unlike anything previously seen in New Zealand. ${ }^{43}$

The tikanga and protocols that were part of the exhibition development represented the affirmation of Ngāti Kahungunu cultural values and knowledge. For example, taonga were welcomed home and the ceremonies and protocols at the opening declared that Ngāti Kahungunu were present. No doubt the impact of the Te Mãori exhibition also played its part, as the tapu-lifting ceremonies, whakawātea and pōwhiri from Te Māori were all taken on board and adapted. ${ }^{44}$

From the start of the exhibition, its curator David Butts knew that the Kahungunu people needed to be involved and he himself reflected on the realization that the primary target of the exhibition had to be the iwi themselves: "In the first instance this exhibition had to be a resource that was useful and inspiring for Ngāti Kahungunu." 45 An indication that this was a resource by Ngāti Kahungunu for Ngāti Kahungunu is seen in the education attendance figures for 1986-87 when it showed that 73 percent of the total numbers attending the education service attended the Kahungunutanga programme that was specially developed for the exhibition. ${ }^{46}$

The Kahungunutanga education programme was developed by Kahungunu kaumātua and the curator David Butts and included three phases: 1) Local traditions: Takitumu, Kahungunu to provide a background to the exhibition; 2) Ngā Tukemata: museum visit, including a pōwhiri

\footnotetext{
41 McCarthy, 2011, 46.

42 See Hawke's Bay Art Gallery and Museum Annual Report, 1987. Sandy Adsett was awarded the award on $26^{\text {th }}$ November by Hon. Mike Moore, Minister of Tourism, at a reception in the Beehive.

43 See Butts, D. 1990. Nga Tukemata: Nga Taonga o Ngāti Kahungunu/The Treasures of Ngāti Kahungunu. The Politics of the Past. P. Gathercole and D. Lowenthal. London, Unwin Hyman (p.113). Adsett painted the walls and ceiling tutaewhetu (blue-coloured clay), including blue carpet on the floor. This was complemented with a small number of taonga, as opposed to a large number of typological displays.

44 Ibid. 50

45 Ibid. 48.

46 Hawke's Bay Art Gallery and Museum Annual Report, 1987.
} 
and experiencing the exhibition and audiovisual; and 3) Otatara pa: An onsite visit showing Ngāti Kahungunu moving south into Heretaunga. ${ }^{47}$

The exhibition proper included taonga provenanced to Ngāti Kahungunu held in museums in New Zealand and the loan of these was consulted and communicated with their kin descendants. The Te Poho o Kahungunu wharenui of Porangahau was given a prime exhibition location within the exhibition setting, as were four poutokomanawa representing four rangatira who had lost their lives defending their land at Te Pakake in the early 1820s. ${ }^{48}$ The exhibition was a celebration of Ngāti Kahungunu history and identity as noted by McCarthy: "The guiding principle of the concept development was a 'celebration of the mana of Ngāti Kahungunu'.,"49

When we consider the propositions of this research, it is important to know what the exhibition did for the people of Ngāti Kahungunu. How important were the taonga on exhibition and what relationship did the Ngāti Kahungunu people have towards their taonga? The answers to these questions are best left to the people themselves. Ngāti Kahungunu people were fully involved in all aspects of the exhibition with Piri Sciascia and Walton Walker writing and producing the audiovisual for the exhibition. This involved visiting many Ngāti Kahungunu marae, photographing wharenui and collating information. ${ }^{50}$ The Māori language labels were written by Canon Wi Te Tau Huata, while the labels written by the curator David Butts were discussed, rewritten and approved by the Kahungunu kaumātua who were acting as advisors. ${ }^{51}$

As commented by Butts: "for these men, and the other men and women involved in the planning, this exhibition was not about the past; it was not just a history exhibition. It was about something they lived every day. It was about being Ngāti Kahungunu, keeping the whakapapa alive... Their history was there in front of them, not behind them in the distant past." 52 Butts knew that this exhibition was about the Ngāti Kahungunu people and their

\footnotetext{
47 Ibid.

48 The chiefs Te Kauru o te Rangi, Te Hūmenga, Te Hauwaho and Whakatō were killed in the pakanga at Te Pakake. These ancestors occupied a prominent place in Nga Tukemata o Kahungunu and the tipuna Te Kauru o te Rangi was exhibited in Te Mãori.

49 McCarthy, 2011, 47.

50 See Hawke's Bay Art Gallery and Museum Newsletter, 1985. All the wharenui and wharekai were photographed as part of the research for the exhibition. They were given guidance by kaumātua, including John Tangiora, Canon Wi Te Tau Huata, Mana Cracknell, Sandy Adsett, Eru Smith, and Tom and Billie Gemmel.

51 Hawke's Bay Art Gallery and Museum Annual Report, 1987.

52 Butts, 1990, 47.
} 
ancestors and a spirituality accorded with the uniting of the past and present: "This exhibition was not the place to write another textbook on the wall; it is a spiritual place where the works of the great Ngāti Kahungunu artists can communicate directly with their descendants, a place where people will acknowledge the presence of the ancestors."

Perhaps there is no better statement than the words that the visitors to the exhibition saw after the welcome in Māori when people entered the exhibition:

\section{Nga Tukemata: The Awakening:}

Nga Tukemata challenges each of us in different ways; for some there will be the discovery of Ngāti Kahungunu as tangata whenua. Ngāti Kahungunu are the descendants of Kahungunu and his wives. Kahungunu was an important ancestor who settled on the east coast of the North Island about 20 generations ago. For some there will be an awakening to Ngāti Kahungunu art as a tradition equal to any in the world. Consider the taonga (artworks) before you as signposts on a journey of discovery.

For Ngāti Kahungunu this exhibition was a celebration of their tipuna (ancestors) and a reminder to the rest that they are still a strong people. You will not find a detailed history written here. That history is known only by the descendants of Kahungunu and can only be given directly from their mouths. The exhibition is a celebration of the mana of Ngāti Kahungunu. It is an attempt to alert you to the mauri (the life essence), the ihi (the power), and the wehi (the awe) which Ngāti Kahungunu feel from their taonga. Taonga are addressed in whaikorero as the living past. Respect the taonga for what they are - a living and powerful dimension of Ngāti Kahungunu culture. ${ }^{54}$

The exhibition had an ongoing impact for Ngāti Kahungunu, as in 1989 an exhibition was held titled Taku Wahine Purotu, Taku Tane Purotu: my beautiful woman, my beautiful man named after a well-known Ngāti Kahungunu waiata. This exhibition ran from $12^{\text {th }}$ to $27^{\text {th }}$ August and the theme was 'balance' and 'completeness', which complemented and continued the ideas that underlined the traditional Ngāti Kahungunu taonga in Ngā Tukemata o Kahungunu. The young artists used the exhibition as an opportunity to show the "assimilation of traditional into a modern context.", 55

A fitting conclusion to Nga Tukemata o Kahungunu are the words of the exhibition's curator David Butts when he reminded us that: "To non-Māori the exhibition also brings a unique message. The taonga convey the particular identity of Kahungunutanga to the viewer without mediation." 56

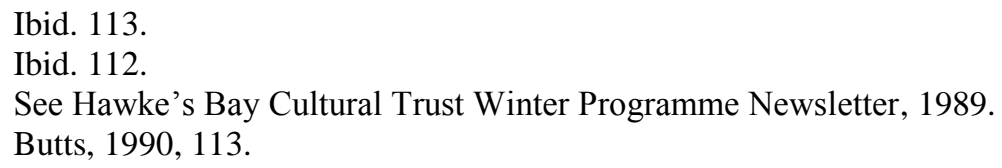




\section{Ngā Taonga o Tamatea 'Hokowhitu' exhibition}

The Ngā Taonga o Tamatea 'Hokowhitu' exhibition was held during the 1990 New Zealand celebrations of the $150^{\text {th }}$ anniversary of the signing of the Treaty of Waitangi. This exhibition followed in the wake of the Ngāti Kahungunu waka project, Tamatea Arikinui, where 22war canoes were commissioned to celebrate the signing of the Treaty of Waitangi. The exhibition was held at the Waipukurau Civic Theatre from $3^{\text {rd }}$ to $17^{\text {th }}$ November 1990 and included 160 taonga from Central Hawke's Bay. These taonga were held by Māori, as well as those in museums, private collections, and in the hands of Pākehā and settler families from the district of Tamatea. ${ }^{57}$ The taonga in the exhibition included a wide range of artefacts, including toki, fishhooks, weapons, reels and necklaces, hei-tiki, cloaks and kete, carvings from the Te Poho o Kahungunu wharenui and contemporary taonga, as well as a Lindauer portrait of the Ngāti Rangikoianake chief, Te Hapuku.

For the organizer of the exhibition, Rangitane (Donald) Tipene, the exhibition was the realization of a 10-year dream. As a descendant of the ancestor Te Angiangi, who first met the European explorer Captain James Cook, it was perhaps more than chance that Donald organized the exhibition, as it was his ancestor who met Captain Cook off Pourerere on $22^{\text {nd }}$ October $1773{ }^{58}$ This exhibition is important as the treasures are located within the region of Tamatea and, as such, include the hapū identities of this region.

The exhibition was organized not long after the highly successful Te Māori exhibition that travelled to four large museums in the United States in 1984-86. Porangahau had special relationships with Te Māori as this was the tūrangawaewae of Piri Sciascia, a key organizer of Te Mãori. The mauri stone of the Te Mãori exhibition was brought to the Rongomaraeroa marae in Porangahau and viewed by the people of the district. ${ }^{59}$

Ngā Taonga o Tamatea 'Hokowhitu' was organized by a board of trustees, with assistance from the Hawke's Bay Cultural Trust Ruawharo Ta-u-Rangi. Other organizations also contributed including Te Rūnanganui o Ngāti Kahungunu, MASPAC, National Museum of New Zealand, Otago Museum, Canterbury Museum, Manawatu Museum, Napier Museum,

57 See Ngā Taonga o Tamatea Catalogue, 1990, p.9. Parsons (1990) says that more than 90 percent of those who loaned taonga to the exhibition asked to remain anonymous. This included Māori and Pākehā families.

58 See Ngā Taonga o Tamatea Catalogue, 1990, p.10. Tuanui was sketched by Cook's artist William Hodges on the Resolution and he was presented by Captain Cook with a spy glass or telescope, the whereabouts of which remain unknown.

59 Ibid. 8. The Kapa Haka Group from the area Tamatea Ariki Nui centred its items on the Te Māori exhibition at the 1984 Festival in Christchurch (p.8). 
New Zealand Film Archives, Turnbull Library, Central Hawke's Bay District Council, ANZ, National Art Gallery Auckland \& Australia, Central \& Southern Hawke's Bay Arts Council and the Tamatea Taiwhenua.

The logo for Nga Taonga o Tamatea 'Hokowhitu' was derived from the carving of the koruru on the original Te Poho o Kahungunu meeting house of Ngāti Kere in Porangahau. This taonga was carved by Matenga Tukareaho of Ngāti Rākaipaaka who was one of the signatories of the Treaty of Waitangi. The exhibition itself was a memorial to Hokowhitu Ropiha who had worked tirelessly to uplift his people. ${ }^{60}$

The views of the Ngāti Kahungunu people about the exhibition are important with respect to the doctoral research question that seeks to articulate the role, if any, Māori taonga play within contemporary Māori communities as part of tribal self-determination and the advancement of Māori development and identity. For those of Ngāti Kere of the Tamatea rohe, its significance was great. For the Chairman of the exhibition, Rangitāne Donald Kakaho Tipene, he believed: "the Taonga of our Tupuna is not a selection of artefacts of a culture that has passed, Nga Taonga is the link that binds us to our tupuna and leads us to our future and lives within us all today." 61 Tipene further said: "It's a very important part of our heritage. This is the only time the taonga of this area have been brought together. This exhibition is not something you can go to the museum and see." 62

For the Ngāti Kere tribal leader, Piri Sciascia, the taonga in the exhibition were about the ancestors and the connections to the present: "These 'taonga', gathered together for this exhibition, help us trace the footsteps of our ancestors. For it is here that we, their descendants, still live, from Kairakau to Akitio, from the deep sea fishing grounds of the coast, to the forest and snow-capped mountains of the Ruahine Ranges." ${ }^{63}$ Sciascia in his writing in the exhibition catalogue further noted that the exhibition took place at a time of cultural renaissance and that the taonga serve as reminders to us of the early Māori settlers of the district and that what remains are 'expressions of our forebears' ${ }^{64}$

60 Ibid.

61 Ngā Taonga o Tamatea Catalogue, 1990, 4.

62 See 'Treasures of Old CHB revealed' article published in the Hawke's Bay Herald, 1990 (Past Perspectives) by Patrick Parsons.

63 Ibid. 7.

64 Ibid. 9. Sciascia also alerted the people to be mindful of the saying 'He Toi Whakairo, He Mana Tangata' (Where there is artistic excellence, there is human dignity). 
The relationship of the treasures within Ngā Taonga o Tamatea 'Hokowhitu' to the future development of the people is perhaps best described by the tribal leader of Te Rūnanganui o Ngāti Kahungunu Incorporated at that time, Charles Tohara Mohi, in the foreword to the exhibition catalogue: “'HE WHAKAOHONGA HOU: Ka ngaro mauri taonga ki Paerau kihai ka mau ki taiao' A NEW AWAKENING: Mana taonga shall be lost to Paerauif we do not uphold them."

\section{National Library Cultural Property Pilot Project}

The National Library of New Zealand Te Puna Mātauranga o Aotearoa Cultural Property Pilot Project was selected as a case study because of its association with Ngāti Kahungunu taonga. This project was initiated by the National Library in partnership with the two major tribes of Wairarapa, Rangitāne and Ngāti Kahungunu-ki-Wairarapa, regarding improving access of material relating to the Wairarapa region held at the library.

The project commenced in 1997-98 and involved the coordinator of the Alexander Turnbull Library's Māori collection, and Rangitāne and Ngāti Kahungunu people, to describe and catalogue the Wairarapa taonga. A key driver of the collaborative research project was to improve access and create a mutually beneficial relationship.

This project offers great value to the present research because an evaluation of the project was undertaken in 1999 by Grant Pittams of the Research Unit of the National Library. ${ }^{66}$ As part of the evaluation report research methodology, kanohi ki te kanohi or face-to-face interviews were undertaken with 17 people, including tribal kaumātua from the iwi authorities of Rangitāne and Ngāti Kahungunu, along with staff at the Masterton library and archive, the Chief Librarian, the Turnbull Library, and National Library staff involved in the project. The evaluation feedback offers this research a good opportunity to assess the significance of the taonga held at the National Library in Wellington to their descendant kin communities.

The project adopted a qualitative research methodology using face-to-face interviews with iwi representatives at venues suitable to them, such as the marae or at their homes. The interviews were loosely structured to encourage a more fluid conversational style. ${ }^{67}$ The

65 Ibid. 2.

66 Pittams, 1999.

67 Pittams, 1999, 5-8. 
findings based on the evaluation report suggest strong relationships with tribal identity, history and belonging. The report noted that the materials were regarded as taonga by the Wairarapa people:

The iwi representatives were very clear in their belief that, material, which is held within the National Library, is part of their history, and as such, they felt a strong link to it... In the Māori paradigm the material held within the National Library is taonga, and as such, forms an important part of their identity. That is, it is part of the iwi past, and tells of events, people, and deeds that need to be remembered and treasured. ${ }^{68}$

One of the main findings of the report centered on the importance of the taonga and their identification back to iwi, hapū and the place of 'Wairarapa':

Whakahokia nga taonga. Which means that this stuff has to come home... most important, is our own identity, our own taonga, our own self coming back in those pages and in those artefacts. It's only here at home can we breathe life into them, and we can give that particular dimension, that particular layer of meaning as it only resides in that context within which those taonga, those books, were created and developed, to have them everywhere else is just false. I couldn't think of anyone more qualified than ourselves. ${ }^{69}$

Other tribal feedback reinforced the importance of mana whenua and the home place:

The Māori side doesn't change very often because of the link to the whakapapa whereas, on the non-Māori side, they change frequently, because for them it's a job, but for us, it's a lot deeper than that and richer... but as a receptacle for the original they should always come back, always to mana-whenua. ${ }^{70}$

Issues centre around partnership/ownership of material that is precious - in a legal sense the material belongs here [the National Library], physically we care for the material. Iwi have a role with that material, in that it concerns their ancestors. ${ }^{71}$

\section{Kahungunu, Ka Moe, Ka Puta exhibition}

The Kahungunu Ka Moe, Ka Puta exhibition was organized between 2000 and 2005. The exhibition highlighted and celebrated a large number of Ngāti Kahungunu ancestors depicted through photographic enlargements of the Samuel Carnell carte de visite photographic collection held at the Turnbull Library in Wellington. Described by some as touching and

Ibid. 3.

Ibid. 11.

70 Ibid. 10. This comment was made in relation to the practical application of parallel partnership.

71 Ibid. 
inspirational, the exhibition brought pride in knowing that they were a part of who you are as Ngāti Kahungunu people. ${ }^{72}$

The Samuel Carnell photographic collection consists of 257 glass plate negatives consisting mostly of carte de visite portraits of Māori with the majority of the named individuals from the Heretaunga region, but also extending out to Mahia and the Wairarapa areas. The majority of the Māori individuals were from Ngāti Kahungunu, while others included those with whakapapa connections to the Rangitāne and Ngāti Porou tribes. ${ }^{73}$

Kahungunu Ka Moe, Ka Puta was first exhibited at the Hawke's Bay Exhibition Centre in Hastings in November 2000, after which it travelled to the National Library of New Zealand Te Puna Mātauranga o Aotearoa in Wellington in $2002\left(9^{\text {th }}\right.$ March $-9^{\text {th }}$ June $)$, the Wairarapa Museum Aratoi in 2004 ( $1^{\text {st }}$ May- $3^{\text {rd }}$ July), with the final venue at the Wairoa Museum, Northern Hawke's Bay, in 2005 ( $6^{\text {th }}$ February-30 ${ }^{\text {th }}$ April $)$.

The exhibition was a partnership between the National Library of New Zealand Te Puna Mātauranga o Aotearoa, Ngāti Kahungunu Iwi Incorporated, and the Hawke’s Bay Cultural Trust Ruawharo Ta-u-Rangi. The title of the exhibition 'Kahungunu Ka Moe, Ka Puta' refers to Kahungunu the eponymous ancestor through to the present day. 'Ka Moe' means to sleep or marry, while 'Ka Puta' means to be born. ${ }^{74}$ To understand the title is to understand the history of Ngāti Kahungunu where the eponymous ancestor Kahungunu had formed strategic relationships by marrying eight wives. From these eight marriages, strategic relationships were established with tribes from the Far North through to Bay of Plenty up to the East Coast. $^{75}$

For the Chairman of Ngāti Kahungunu Iwi Incorporated, Ngahiwi Tomoana, Kahungunu established an array of political, economic, social and cultural relationships. Tomoana believed that the mareikura anchored the kawa and tikanga and that 'ka moe, ka puta' stands as a metaphor for how we live and move forward:

72 Pittams, 2002; Conference of Directors of National Libraries in Asia and Oceania (CDNLAO). 2005. Newsletter, no. 52, March 2005.

73 See Simpson and Parsons, 2003. The Carnell Photographic Collection was retained by the family and donated to the Alexander Turnbull Library in 1963 by his grandson Mr Edward Spraggon (p.9).

74 See Ngāti Kahungunu Iwi Inc. website.

75 The marriages have created strategic alliances with a number of tribes and these are often recounted on marae throughout New Zealand. 
The ahikaroa is deeply entrenched but we say the mareikura, it's the mareikura that puts in the roots, that anchors our tikanga and kawa but the whatukura moves and so, ka moe, ka puta, ka moe, ka puta, ka moe, ka puta, pokai whenua, pokai moana, pokai ao, mai tawhiti, tawhiti atu, we're just using those standards of our whakatauki as a metaphor for how we move on today. ${ }^{76}$

The origin of Kahungunu Ka Moe, Ka Puta, however, was in Hastings when the Ngāti Kahungunu tribal leader and elder Tohara (Charlie) Mohi was researching documents relating to the kawa of Ngāti Kahungunu held at the Turnbull Library in Wellington. While there he uncovered the Samuel Carnell carte de visite photographic collection of Ngāti Kahungunu ancestors. ${ }^{77}$ After discussions with the National Library staff and Ngāti Kahungunu kaumātua, a set of Carnell prints were exhibited at Mihiroa marae in Pakipaki, 5 kilometres South of Hastings, under the title 'Nō hou ōu Tipuna pea?'78

This mini exhibition generated a lot of interest and I personally travelled to see this exhibition at Pakipaki. While there, I was asked to share perspectives on some of the ancestors and it was an experience that I will never forget. Having a large number of ancestral portraits in one place on a marae with descendants greeting and lamenting them was both highly emotional and personally transformational. From that marae exhibition there emerged the idea to hold a large exhibition and tour it around the tribal lands. Researchers from within Ngāti Kahungunu were selected to further develop the exhibition ideas as they were already advancing wānanga as part of their strategic plans. The Kahungunu Iwi Incorporated website recalls the following: "There was an advance of Ngāti Kahungunu Iwi Inc. in 2000, to spearhead wānanga in their strategic plan for the Iwi (tribe). Through four representative researchers, of the three traditional areas of Kahungunu, Pita Robinson of Te Wairoa, Ngātai Huata, and Te Koha Tareha of Heretaunga and Francis Reiri-Smith of Te Wairarapa; emerged the exhibition." 79

Kahungunu Ka Moe, Ka Puta consisted of 33 carte de visite photographic images from the Samuel Carnell archive collections held at the Alexander Turnbull Library. The Carnell photographic collection is considered one of the more significant collections held at the National Library, consisting of 270 subjects that were taken by Carnell in the 1880 s to

\footnotetext{
6 Ngahiwi Tomoana interview, September 2011.

77 See Robens 2005; Pittams, 2002. See also Ngāti Kahungunu Iwi Inc. website.

78 Pittams, 2002 ditto, 6. See also Ngāti Kahungunu Iwi Inc. website.

79 Ngāti Kahungunu Iwi Inc. website. http://www.kahungunu.iwi.nz/sections/iwi_development/whatwedo/Ka_moe_Ka_Puta_05.htm.
} 
1890s. ${ }^{80}$ The exhibition of Carnell photographs was also supplemented with taonga selected largely from museums, such as the Hawke's Bay Cultural Trust, along with a strong programme of events and lectures at all the host venues.

The exhibition proper included a selection of the Carnell collection of carte de visite photographs where 260 of the photographs were taken mostly of Kahungunu tipuna. Many of these photographic images were blown up and given a real life presence within the exhibition. A central element of the exhibition was whakapapa, as noted on the Ngāti Kahungunu Iwi Incorporated website: "Whakapapa is the exhibition's key element that gives a direct and relevant link from individuals in the portraits to the viewer."

This exhibition had a personal dimension for me, as my great grandparents Arapeta and Ripeka Hakiwai, were also included in the Carnell photographs selected for the exhibition. ${ }^{82}$ For me, it was about my identity and personal history. In relation to this thesis, it was a personal ethnographic reflexive discourse where I was commenting on something that I had experienced. It was a graphic reminder of my past and my family's future. The exhibition opened at the Hawke's Bay Exhibition Centre in Hastings with the title 'Kahungunu, Ka Moe Ka Puta: Portraits of Ngāti Kahungunu 1870-1906.' The title recognized the many offspring of the eponymous ancestor Kahungunu and his eight wives. The exhibition proper included taonga, exhibition guides and a strong visitor events and lecture programme. There was strong Ngāti Kahungunu involvement in the exhibition, as Huria Robens says:

The images, essays and taonga were complemented by guides from the tribe who took pride in showing visitors the exhibition and delivered the biographic stories of their ancestors. In addition, there was a significant events programme that included workshops, lectures, storytelling, performances of tribal waiata and a stage production that through both traditional and contemporary song \& dance, told the story of Carnell meeting \& photographing the ancestors. It broke visitor records to the venue and showcased artefacts from the museum ... and it built capacity within the tribe and created new knowledge about their history. ${ }^{83}$

An important element of Kahungunu Ka Moe, Ka Puta in Hastings was an evaluation of the exhibition carried out by the Research Unit at the National Library of New Zealand. This report highlighted a number of key findings and recommendations based on the qualitative research methodology of face-to-face interviews with kaumātua or tribal elders, researchers

80 See Sullivan, John. 2002. "The Portraits of Samuel Carnell: The Representation of Ngāti Kahungunu in Colonial Photography". History of Photography no. 26:351-357.

81 Ngāti Kahungunu Iwi Inc. website.

82 The image of Arapata and Ripeka Hakiwai was the only one taken of a couple sitting together.

83 Robens, 2002, 4. 
and iwi authorities. ${ }^{84}$ The report's objectives included assessing the extent of the outcomes, objectives and expectations of the partners in the exhibition, as well as identifying better ways in which the National Library could improve its practices in partnership ventures. ${ }^{85}$

The evaluation of Kahungunu Ka Moe, Ka Puta provides both quantitative and qualitative data for my research question in seeking to understand the nature of Māori taonga and the complexities of the politics of Māori tribal identity and development. What was noticeable in the Evaluation Report of the exhibition was that Ngāti Kahungunu has started the process of telling its stories to all New Zealanders and, through this, enhancing the mana of Ngāti Kahungunu. ${ }^{86}$ An important realization of the significance of the Samuel Carnell photographs to Ngāti Kahungunu and the National Library occurred early on in the project. Charlie Mohi realized the significance of connecting the whakapapa with the tipuna to provide a living dimension and the exhibition was seen as a way to link the past with the present.

In order to get the project underway, a meeting was arranged between the iwi and the Library. Ngāti Kahungunu was shown a model whakapapa, plus a large photo of the Iwi Chairperson's grandfather. Ngāti Kahungunu saw that the whakapapa linked the photos and the photos made the whakapapa come alive. The Iwi Chairperson felt that the photo collection was a logical and modern extension of traditional carving techniques; he commented that carvings had their whakapapa, but unless one knows the carver, or the whakapapa was written, often the subject of the carving is not known. To Ngāti Kahungunu, the photos are an invaluable insight into their whakapapa. An exhibition was therefore seen as a way to link together the past and the present. ${ }^{87}$

The key findings of the Exhibition Evaluation Report are important for this research as they articulate the reactions and experiences of Ngāti Kahungunu tribal members. The report, however, centred on the partnership of the three organizations involved in the exhibition and, in particular, the process of dialogue and understanding. ${ }^{88}$ Some of these key findings included:

\footnotetext{
84 The report notes that the interviews were loosely structured and more in a conversation style (p.11).

85 Pittams, 2002.

86 Ibid. 6.

87 Ibid. 12.

88 Ibid. 13.
} 
- "The exhibition has provided the Iwi with further insights into its history and in the opinion of some, has provided an important focus for the young and unconnected on their heritage.” (p.6)

- $\quad$ "From the three partners' point of view the exhibition has provided a powerful tool to link people to their heritage." (p.7)

- "It is very pleasing to see the high proportion of Māori attending the exhibition. From the interviews it seems that Kahungunu felt that this was 'their' exhibition and 'their' place." (p.27)

The feedback from Ngāti Kahungunu tribal members to the exhibition affirmed the importance of the ancestral images to Ngāti Kahungunu identity. Some of the comments included:

- "We walked in and felt the mana. We saw the relationships. There was the tipuna and there was us."

- "The exhibition made the stories come to life."

- " $\quad$ It gave you an understanding of part of who you are. It made one proud."

- “The exhibition is Māori - is Kahungunu - it didn't have borders and didn't have limitations."

- $\quad$ "I am of Tuhoe descent and at the moment looking into my whakapapa. I found that coming here has made me realize how important it is for me to find out about my own identity."

- $\quad$ "A rare privilege to see so many photos and paintings of ancestors of Ngāti Kahungunu. People from the past who in their own way help to pave the footpaths for the future of their mokopuna." 89

After the success of the mini exhibition at Pakipaki and Kahungunu Ka Moe, Ka Puta, and following the untimely death of Tohara Mohi, the National Library, in consultation with Ngāti Kahungunu, committed staff and financial resources to research the images with a view to making them more accessible by way of an exhibition and supporting publication. ${ }^{90}$ The outcome of this was that the exhibition travelled to a further three venues and a publication titled Ngā Taumata: A Portrait of Ngāti Kahungunu: He whakaahua o Ngāti Kahungunu 1870-1906 was published.

89 Ibid. 33-34.

90 Pittams, 2002, 8-9. 
The first hosting venue after Hastings was the National Library of New Zealand in Wellington where the title became Kahungunu Ka Moe Ka Puta: Te Hononga Māreikura. This title represented a natural progression where Kahungunu links and relationships to Te Whanganui-ā-Tara or the Wellington region were acknowledged. ${ }^{91}$ The words 'Te Hononga Mareikura' referred to the spiritual union of precious heirlooms and recognized the visit to the National Library in 1998 by the Ngāti Kahungunu leader, Tohara (Charlie) Mohi. ${ }^{92}$ The events programme for the exhibition in Wellington included lectures and performances and a number of high-quality Ngāti Kahungunu speakers and performers talking about tribal history, ancestors, art, waiata and relationships with other tribes. ${ }^{93}$

Kahungunu Ka Moe Ka Puta: Te Hononga Māreikura at the National Library was promoted as a major exhibition in the 2002 International Festival of the Arts Programme. The image on the exhibition catalogue at the National Library in Wellington was of my great grandparents, Arapeta and Ripeka Hakiwai, whose portrait was taken of them both together. For me personally, it was a celebration of my tribal, sub-tribal and whānau identity brought to life through the large reproductions of the small Carnell carte de visite images.

Following the success of the exhibition at the National Library in Wellington, it then travelled to the Wairarapa where it opened with great ceremony and celebration at Aratoi Wairarapa Museum and Art Gallery on $1^{\text {st }}$ May 2004. In a similar way to the Hastings and Wellington venues, the exhibition title was added to and became Kahungunu Ka Moe Ka Puta: Te Hokinga mai o te Whare Wānanga. The added suffix referred to the return of the sacred lore of knowledge which Wairarapa was so renowned for. ${ }^{94}$

Like the Ngāi Tahu Mō Tātou exhibition, the Wairarapa venue incorporated a strong component from the Wairarapa region. Kaiārahi or guides gave tours throughout the week of the exhibition and six Wairarapa marae and two hapu hosted weeks and supported exhibitions in the Wesley Wing of Aratoi. Marae and hapū kaiārahi conducted tours of their exhibitions throughout the exhibition. The order of the marae/hapu weeks as outlined in the events programme included:

91 Kahungunu Ka Moe, Ka Puta exhibition catalogue.

92 Ibid.

93 The events programme included the sharing of whakapapa and tribal history, including a celebration of traditional and contemporary waiata. The Kahurangi Group reenacted the historic portraiture with a theatrical ensemble that included waiata from Paraire Tomoana and Apirana Ngata.

94 Wairarapa was recognized as a powerful whare wānanga associated with Tūpai Whakarongo Wānanga. 


\begin{tabular}{|l|l|}
\hline Date & Marae/hap $\overline{\mathbf{u}}$ \\
\hline $1^{\text {st }}-9^{\text {th }}$ May & Te Oreore marae \\
\hline $11-16^{\text {th }}$ May & Te Hika a Papauma \\
\hline $18^{\text {th }}-23^{\text {rd }}$ May & Te Rangimarie marae \\
\hline $25^{\text {th }}-30^{\text {th }}$ May & Papawai marae \\
\hline $1^{\text {st }}-6^{\text {th }}$ June & Hurunuiorangi marae \\
\hline $8^{\text {th }}-13^{\text {th }}$ June & Kohunui marae \\
\hline $15^{\text {th }}-20^{\text {th }}$ June & Tūmapuhia a rangi $^{\text {th }}$ \\
\hline $22^{\text {nd }}-27^{\text {th }}$ June & Pouakani marae. \\
\hline
\end{tabular}

Exit interviews were also taken in Wairarapa where visitors were asked whether they were satisfied or very satisfied with the exhibition, as well as what the exhibition meant to them personally. The responses provide both quantitative and qualitative evidence for my research question that seeks to understand the role Māori taonga play within contemporary Māori communities as part of tribal self-determination and the advancement of Māori development and identity. As reported by Penny Carnaby, Chief Executive and National Librarian of the National Library of New Zealand: ${ }^{96}$

\begin{abstract}
Visitors were asked what the exhibition meant to them personally. They responded by saying that they found the experience something that was very personal, spiritual and emotional that created a sense of connectedness that previously they had not felt before when visiting an exhibition. For many, the sense of place and belonging created by the exhibition was awe-inspiring. 'It was touching and inspirational'; 'It made me think'; 'It was an awakening time for me'; 'Spiritually, emotionally, I am full of the knowledge of my tipuna. ${ }^{97}$
\end{abstract}

These responses are very similar to those who experienced the National Library venue. They all touched on the importance of the ancestors and the relationships to Ngāti Kahungunu culture and identity.

The last venue for Kahungunu Ka Moe, Ka Puta was the Wairoa Museum in Northern Hawke's Bay from $6^{\text {th }}$ February 2005 to $30^{\text {th }}$ April 2005. Here the organisers of the exhibition in Wairoa named the exhibition Kahungunu Ka Moe Ka Puta... Te Parekereketanga a ngā Rangatira (Kahungunu who copulated and procreated the seedbed of chiefs). The Wairoa suffix to the exhibition was in reference to the great Wairoa ancestors, such as Te Kapuamatotoru and his wife Te Whewhera, both descendants of Kahungunu, who resided in close proximity to Wairoa township. As Nigel How, the exhibition co-coordinator and cocurator noted: "Their impeccable lineage from the great ancestors Tapuwae and Te Huki saw

95 See the Events Programme for Aratoi: Wairarapa Museum of Art and History, 2004.

96 CDNLAO, 2005.

97 Ibid. 
them referred to as 'the seedbed of chiefs', where their offspring were used to populate the district with royal and aristocratic families." 98

Kahungunu Ka Moe, Ka Puta journeyed throughout the tribal territory and reconnected with the descendants of the tipuna as depicted through the Carnell photographic images. The impact that the exhibition had during this time was creating new enthusiasm and interest in Ngāti Kahungunu taonga. Another important exhibition was soon to follow that also featured portraits of Ngāti Kahungunu people. This exhibition was titled Gottfried Lindauer Te Renitawa. The Shadow Maker and was held at the Hawke's Bay Cultural Centre in December 2005. The exhibition featured a number of paintings by the colonial portrait artist, Gottfried Lindauer. ${ }^{99}$ Celebrating the $80^{\text {th }}$ anniversary of his death in June 1926, the exhibition included a large number of paintings of Ngāti Kahungunu people.

This exhibition once again reconnected kin with their ancestors in a similar way that Kahungunu Ka Moe, Ka Puta did in Hastings in November 2000. Patrick Parsons, the exhibition curator, wrote in the exhibition catalogue that "on marae they [i.e. the portraits] are regarded as taonga." $" 100$ I also attended the exhibition and for me and many other tribal descendants of the ancestors, they represented the past and future, the history and hap $\bar{u}$ identities of where we had come from and by association the pride and joy of a cultural foundation for the future.

\section{Analysis and Discussion}

The feedback from Ngāti Kahungunu tribal members on the Ngāti Kahungunu exhibitions and cultural projects examined in this chapter shows tribal taonga as strong identity markers of Ngāti Kahungunu tribal and hapū identities. When we look at the operations of the Ngāti Kahungunu tribal authority, we see that the future development of Ngāti Kahungunu has Ngāti Kahungunu culture and identity at the heart. The mission statement is clear and unequivocal in promoting and advancing the uniqueness of Ngāti Kahungunu: 'Kia

98 Letter from Nigel How of the Ngāti Kahungunu (Wairoa Taiwhenua) Arts and Culture Board, to Arapata Hakiwai, Te Taumaru Herenga-a-iwi, Te Papa Tongarewa, dated $3^{\text {rd }}$ November 2004.

99 See Gottfried Lindauer: Te Renitawa. The Shadow Maker exhibition catalogue published by the Hawke's Bay Cultural Trust, 2005. Lindauer was born at Pilsen and was the major portrait artist of colonial Hawke's Bay. Lindauer painted the major Māori and Pākehā personalities in the era between 1875 and 1900. The exhibition opened at the Hawke's Bay Exhibition Centre on $10^{\text {th }}$ December 2005 and closed on $26^{\text {th }}$ February 2006. It is believed that Lindauer used the Samuel Carnell carte de visite photographs as a basis for his paintings between 1880 and 1920 (Sullivan, 2002, 357).

100 Ibid. 
maumahara ki te mana āhua ake o Ngāti Kahungunu' (Uphold the absolute uniqueness of the living breath of Kahungunu and to enhance the mana and well-being of Ngāti Kahungunu Iwi).

If we look at Ngāti Kahungunu's 25-year vision, we also see that the culturally strong objective with its seven main areas reaffirms the importance of Ngāti Kahungunu identity as an integral and important dimension of Ngāti Kahungunu development. Also included within the seven areas are four specific objectives that have a strong taonga focus. One of these, the creation of a Kahungunu Cultural Centre with archives and the contemporary development of the arts, signals to the world the important relationship that Ngāti Kahungunu taonga play with regard to Ngāti Kahungunu identity and development futures.

When the Chief Executive Officer for Ngāti Kahungunu Iwi Incorporated was asked what were some of the aspirations for Ngāti Kahungunu tribal development in the future, her reply was that Ngāti Kahungunu was developing an innovation centre where taonga could be housed and where Ngāti Kahungunu hapū could tell their own stories. This innovation centre was a facility where Ngāti Kahungunu identity could be raised. ${ }^{101}$ This is important to the research question, as it signals the importance of Ngāti Kahungunu taonga to Ngāti Kahungunu identity, as well as affirming the developmental cultural aspirations of the tribe. The innovation centre one can argue is about the people, for the people. Clearly the Ngâti Kahungunu tribal authority sees a place and role for Ngāti Kahungunu taonga and, like their policies and initiatives, see art and culture as the heart and soul of the tribe.

The Cultural Standards project illuminates the significance of this relationship emphasizing the importance of Ngāti Kahungunutanga to the tribe's future development. The Chairman of Ngāti Kahungunu Iwi Incorporated, Ngahiwi Tomoana, adopted the words 'taku wahine purotu, taku tane purotu' as the tribal philosophy for the tribe and this is important as these words come from a well-known Ngāti Kahungunu waiata oriori 'Pinepine te kura'. They express the viewpoint that there must be a strong cultural component, including education, te reo and knowledge, for Ngāti Kahungunu to grow into the future. Adopting the symbolism of a tōpuni tauwhainga or chiefly cloak for the cultural standards projects highlights the importance of Ngāti Kahungunu taonga both symbolically and physically.

${ }^{101}$ Meka Whaitiri interview, October 2011. Meka noted that the Board had undertaken a feasibility study and that they liked the Te Papa model where iwi could display their taonga and tell their own stories. 
The strongest statement regarding Ngāti Kahungunu's relationship with their identity and development comes from the Chairman of Ngāti Kahungunu Iwi Incorporated, Ngahiwi Tomoana, who asserted that the arts occupy a pivotal position for the ongoing development of Ngāti Kahungunu and that the language is the soul of the arts: "Yeah we say that the arts are the soul of the iwi and the reo is the soul of the arts. So unless the arts are foremost in our thinking then we're not going anywhere." ${ }^{102}$ This position is reaffirmed with Ngāti Kahungunu Iwi Incorporated's 25 Year Vision where one of the strategic priorities is 'culturally strong.' The 25-year vision notes that 'Retention of our cultural identity is paramount for it is the soul of the iwi, what makes us unique."

The feedback from tribal members provides quantitative and qualitative evidence that Ngāti Kahungunu exhibitions celebrate tribal identity. The celebration of the ancestors recognized whakapapa relationships that linked the past with the present. The involvement of the descendants in the events programme in Kahungunu Ka Moe, Ka Puta reaffirmed the continuing importance of the ancestral world and taonga to present generations. The mini exhibition that was held at the Mihiroa marae in Pakipaki organized by the Ngāti Kahungunu tribal leader Tohara Mohi as a pre-cursor to Kahungunu Ka Moe, Ka Puta reinforces the position that Ngāti Kahungunu have with respect to Ngāti Kahungunu tribal identity and development: "the photos are an invaluable insight into their whakapapa. An exhibition was therefore seen as a way to link together the past and the present."103

In celebrating the mana of Ngāti Kahungunu as the guiding principle the Nga Tukemata $o$ Kahungunu exhibition at the Hawke's Bay Cultural Trust (Napier Museum) presented tribal taonga within a strong cultural context that recognized and affirmed Ngāti Kahungunu tribal identity. The exhibition acknowledged that whaikorero, karakia and waiata were important taonga of Ngāti Kahungunu and along with the physical taonga were expressions of Ngāti Kahungunutanga.

As Susan Pearce notes in relation to the life histories of objects: "Objects, we have noted, have lives, though finite, can be very much longer than our own. They alone have the power, in some sense, to carry the past into the present by virtue of their 'real' relationship to past events." ${ }^{104}$ For Ngāti Kahungunu, this has been true of the exhibitions and taonga projects examined in this research. The taonga in Kahungunu Ka Moe, Ka Puta possessed the power

\footnotetext{
102 Ngahiwi Tomoana interview, September 2011.

103 Pittams, 2002, 12.

104 Pearce, 1994, 24.
} 
to connect the past with the present, as did the other exhibitions. For Ngāti Kahungunu, the relationships established were of great significance and through the reconnection process with their ancestral treasures they brought the past into the future as part of history in the making. As Pearce says: "The essence of the link is relationship; that relationship is always in process, and process is always bringing about the change which we see as history in the making.",105

For Ngāi Tahu, the Waitangi Treaty claim became the code word for resistance and tenacity and it became closely aligned to Ngāi Tahu identity. For Ngāti Kahungunu, the strong relationships formed through whakapapa and expressed in taonga like whakairo and ancestral portraits became powerful symbols and markers of Ngāti Kahungunu tribal and hapū identity. Like the Ngāi Tahu Mō Tātou exhibition, the Ngāti Kahungunu exhibitions connected the past with the future, the tipuna of old with the generations of today.

The importance of taonga to tribal identity and to the future was perhaps best noted by Donald Tipene and the late Tohara Mohi with regard to the Ngā Taonga o Tamatea exhibition. Donald Tipene said that "the Taonga of our Tupuna is not a selection of artefacts of a culture that has passed, Ngā Taonga is the link that binds us to our tupuna and leads us to our future and lives within us all today." 106 The words written by Tohara Mohi in the catalogue to the Nga Taonga o Tamatea exhibition are also important as the exhibition's plea is to keep the mauri alive lest all will be lost to Paerau: "Ka ngaro mauri taonga ki Paerau kihai ka mau ki taiao.”

Ngāti Kahungunu people understood the meaning of their taonga and found their identity in the taonga. ${ }^{107}$ Ngāti Kahungunu people carry an identity and conception of their past and future, as Poole reminds us: "As in memory and anticipation we identify with past and future selves and appropriate their actions as ours, so we make ourselves one with those past and future selves." 108 As was the case with Ngāi Tahu, Ngāti Kahungunu identity was tied up with both history and modernity. Adopting Hall's cultural identity philosophy, Ngāti Kahungunu cultural identity is not fixed or frozen, but rather it is being played out through

\footnotetext{
105 Ibid.

106 Ngā Taonga o Tamatea Catalogue, 1990, 4.

107 Poole, 1999, 13.

108 Ibid, 64.
} 
ongoing relationships between both the past and future. It is as much about who we are and where we belong as Ngāti Kahungunu as it is with becoming and being in this new world. ${ }^{109}$

\section{Conclusion}

Examination and assessment of the Ngāti Kahungunu exhibitions and taonga-related projects tells us that taonga continue to be relevant and important for the tribal descendants. For many, the taonga were markers of identity and their whakapapa joined the past with the present. For Ngahiwi Tomoana, the arts are the soul of the people and the development of the tribe in future affirms this positioning. The evaluation report of the National Library of New Zealand Cultural Property Pilot Project that was undertaken in 1997-98 reaffirms the cultural importance of the Wairarapa taonga to the Wairarapa people. For many it was 'their' taonga, 'their' place and 'their' identity.

The people saw exhibitions like Kahungunu Ka Moe, Ka Puta as a celebration of their past through the whakapapa and mana of their tipuna. They saw them as exhibitions of Māori, of Kahungunu. They saw the ancestors as providing pathways for the future and the titles of the exhibition in the four venues (Hastings, Wellington, Wairarapa and Wairoa) emphasized the importance of hapu histories and identities, as well as the continuing importance of building relationships in the same way that the ancestor Kahungunu did with his eight marriages.

The relationship between Ngāti Kahungunu identity and Ngāti Kahungunu development is closely intertwined and one can see that Ngāti Kahungunu development cannot proceed without taking their culture with it. This is no better illustrated with than by what the Chairman of Ngāti Kahungunu Iwi Incorporated, Ngahiwi Tomoana, said: "for me for Kahungunu, is about the arts, the business; the economic development cannot go without the cultural development." 110 This position is further reaffirmed with Ngāti Kahungunu's Iwi Incorporated 25 Year Vision where one of the strategic priorities is 'culturally strong.' The 25 -year vision demonstrably asserts that "Retention of our cultural identity is paramount for it is the soul of the iwi, what makes us unique."

Ngāti Kahungunu place great emphasis on the future dimension or, in Sissons' words, the recognition of indigeneity. For Ngāti Kahungunu, the appropriation, transformation and reconnection have always been about the future. Ngāti Kahungunu have reclaimed and

\footnotetext{
109 Hall, 1997, 3, 225.

110 Ngahiwi Tomoana interview, October 2011.
} 
reconnected not only with their past lives, but also the present conditions for the future lives of Ngāti Kahungunu people. ${ }^{111}$ In summarizing this chapter, the words of Donald Tipene perhaps best sum up my research question when he remarked: "The Taonga of our Tupuna is not a selection of artefacts of a culture that has passed, Nga Taonga is the link that binds us to our tupuna and leads us to our future and lives within us all today." 112

111 Sissons, 2005, 11, 140.

112 See Ngā Taonga o Tamatea Catalogue, 1990. 


\section{Chapter Five: Toitū te Mana: Taonga Tuku Iho, Taonga Tüturu - An Enduring Tribal Legacy}

\section{Introduction}

This chapter follows on from Chapters Three and Four that examined Ngāi Tahu and Ngāti Kahungunu tribal identity and development. The chapter looks at a number of selected iwi organisations with respect to their cultural heritage and development initiatives. A number of contemporary iwi projects are highlighted in this chapter including the journeys of two tribal meeting houses Mataatua and Te Hau ki Türanga, Ngāti Porou's Waitangi Tribunal claim letter of commitment for nga taonga tuku iho o Ngāti Porou, ancestral photographs of Whanganui ancestors, and the digital repatriation of taonga belonging to Te Aitanga-a-Hauiti of Ūawa, Tolaga Bay.

This chapter examines Māori tribal taonga from the discourse of a kaupapa Māori paradigm and further extends the understanding of taonga from a tribal perspective, seeking to understand the customary concepts, words and traditions from within these tribes. Chapters Three and Four examined Ngāi Tahu and Ngāti Kahungunu policies, practices and operations through their tribal organisations along with an examination of their exhibitions and cultural heritage projects. The main body of this chapter examines contemporary understandings of tribal taonga from 'insider' iwi perspectives, including Ngāti Porou, Te Aitanga-a-Hauiti, Ngāti Awa and Rongowhakaata.

The chapter highlights important Māori concepts, such as mana, taonga tuku iho and taonga tuturu, within the descriptor of toitū, which is a term that conveys an 'enduring' element. The views of Ngāti Awa and Rongowhakaata regarding their wharenui Mataatua and Te Hau ki Türanga are highlighted within the context of their respective Waitangi Tribunal claims and repatriation initiatives. Adopting Simpson's writing on repatriation with respect to the "recognition of the contemporary value of heritage for living cultures", 1 this chapter will show how the restoration of these two major tribal taonga is contributing to healing, cultural renewal, revitalization and wellbeing.

Similarly, this chapter will show how Mataatua and Te Hau ki Tūranga are major taonga within their tribes that express and manifest tribal identity and futures planning. This

Simpson, 2009, 122. 
positioning aligns well with what the First Nation writer Richard Hill describes as 'regenerating identity' with respect to repatriation: "Culture is, indeed, more than objects, but for many Native American nations, there are certain objects that are essential to manifesting that culture." A strong theme of this chapter concerns repatriation and with it related themes, such as reconnection, restoration and revitalization.

The chapter is primarily concerned with examining what kupu and concepts tribes are using to reference their cultural heritage and what role taonga play in intergenerational sustainability in economic, social and cultural terms. The data for this chapter is based on interviews with tribal members, information published on tribal websites, tribal annual reports and published material in books, journals and articles.

The first tribal project concerns the Ngāti Porou Waitangi Tribunal claim letter of commitment in the Deed of Settlement developed with Archives New Zealand Te Rua Mahara o Aotearoa, the National Library of New Zealand Te Puna Mātauranga o Aotearoa, and the Museum of New Zealand Te Papa Tongarewa (Te Papa) in 2010-13. This tribal claim is important to the research as it was one of the first Waitangi Tribunal claims that specifically targeted Ngāti Porou 'taonga', such as archives, photographs, manuscripts and physical taonga held in these three government organizations, as part of their cultural redress provisions. ${ }^{3}$

The second tribal taonga project concerns the Te Aitanga-a-Hauiti tribe of Ũawa, Tolaga Bay, on the East Coast of the North Island. This tribe has been at the forefront of innovative digital repatriation initiatives reconnecting their tribal taonga with their tribal descendants and holding tribal art exhibitions and wānanga, and creating relationships and partnerships with museums, universities and research centres. One of their innovative digital taonga projects is 'Te Ataakura: Reconnecting voyage collections in archives and museums through the creation of a digital taonga project', which has seen Te Aitanga-a-Hauiti travel the world, reconnecting them with their tribal taonga in distant lands. Re-enlivening and renewing the cultural identity of Te Aitanga-a-Hauiti, based on the traditions and teachings of the Te Rāwheoro Whare Wānanga, is a major feature of Te Aitanga-a-Hauiti tribal identity and development.

Hill, 2007, 313.

Other tribes, including those in Wellington, have subsequently adopted similar provisions to Ngāti Porou's letter of commitment. 
The third taonga example concerns the Rongowhakaata carved meeting house Te Hau ki Türanga that is on display in the Museum of New Zealand Te Papa Tongarewa in Wellington. This wharenui was carved by the Rongowhakaata master carver Raharuhi Rukupo in the early 1840s and confiscated by the Crown in 1867. For Rongowhakaata, Te Hau ki Türanga has become both a symbol of past injustices and a significant taonga for a new and revitalized future. Te Hau ki Türanga is a treasure of great mana for Rongowhakaata and its relationship with its people, both in terms of Rongowhakaata tribal identity and development, is examined.

The fourth example concerns the well-known Ngāti Awa carved wharenui Mataatua that was returned to Ngāti Awa as part of their Waitangi Tribunal claim settlement in 2003.

Mataatua's history includes overseas empire exhibitions, variable relationships with the Otago Museum, dismissive Crown relationships, and ultimately its return home to Whakatāne in September 2011. The story of Mataatua is a tragic and sad one, but its relationship with its people of today offers a renewed pride within its own home environment, as opposed to its classification as a museum ethnological curiosity.

Mataatua has become an important symbol of Ngāti Awa's restorative justice with the Crown and an important taonga for Ngāti Awa's tribal development future.

\section{Ngāti Porou - Toitū te mana}

\section{"Ko Hikurangi te maunga, Ko Waiapu te awa, Ko Ngāti Porou te iwi",}

An examination of the Ngāti Porou Waitangi Tribunal claim has been chosen because it is a contemporary example of a claim, having been signed on $22^{\text {nd }}$ December 2010, as well as including an innovative letter of commitment (LOC) concerning the facilitation of the care and management of, access to, and use, development and revitalization of Ngāti Porou taonga held at Archives New Zealand, the National Library of New Zealand and the Museum of New Zealand. The LOC was signed by these organisations and Ngāti Porou in September 2014 and offers a good opportunity to assess the relationship between Ngāti Porou and their taonga.

\footnotetext{
4 A well-known Ngāti Porou tribal pepehā that encapsulates Ngāti Porou tribal identity. The translation is 'Hikurangi is my mountain, Waiapu is my ancestral river, and Ngāti Porou is my tribe'.
} 
The title to this doctoral research Bits and pieces all over the place-making us whole again was the sentiment expressed by Dr Linda Tuhiwai Smith, one of the members of Ngāti Porou's Waitangi Tribunal Claimant Group Te Haeata, when meeting with representatives of Te Papa, Archives New Zealand and the National Library of New Zealand at a joint meeting in Wellington in April 2010. The meeting was held to discuss the Ngāti Porou Waitangi Tribunal Deed of Settlement letter of commitment relating to the care and management of, access to, and use, development and revitalization of Ngāti Porou taonga.

The words used by Smith are significant to the research dissertation as they convey the strong sentiments of Ngāti Porou people with regard to their tribal taonga. Smith noted how their tribal taonga were scattered throughout the world and located in museums and galleries through the process of colonization, European expansionism and globalization. Her plea was to have these taonga returned to Ngāti Porou as they belonged to the people and were important to their tribal history and identity. Smith's comments are similar to the views of Moira Simpson when she notes that "the contemporary value of heritage for living cultures."

Ngāti Porou is a large tribe that resides on the East Coast of the North Island. Ngāti Porou has 71,895 tribal members as per the Government Census in 2006, of which 12,402 reside in the Gisborne region. Of this figure, 4,212 live in Gisborne city while 8,202 live in the rural areas. Ngāti Porou is also located in large numbers outside their tribal lands with the largest concentrations being in Auckland (13,215), Wellington (11,268), and the Bay of Plenty $(7,602)$. There are 47 marae and 58 hapū within the Gisborne-Ngāti Porou region ${ }^{6}$ and a unique feature of Ngāti Porou demographics is that 58 percent of those who live in the tribal rohe are under 30 years of age. ${ }^{7}$ The tribal lands of Ngāti Porou are from Pōtikirua in the north to Te Toka a Taiau in the south, ${ }^{8}$ while the ancestral waka is Horouta with strong relationships with the Takitimu waka.

There are many prominent ancestors associated with Ngāti Porou with Porourangi being the eponymous ancestor after whom the tribe is named. Porourangi is an important tipuna because many lines of descent from ancient ancestors in Hawaiki and Toi converge on him

\footnotetext{
5 See Simpson, 2009, 122. Simpson explores the link between heritage, health and wellbeing and believes that colonized indigenous peoples are seeking to restore and revitalize their traditional values and cultural practices as a process of renewal to strengthen cultural identity.

See Te Rūnanga o Ngāti Porou website. Ibid.

8 Te Ara: The Encyclopedia of New Zealand - Ngāti Porou Story (p.2). http://www.teara.govt.nz/en/ngatiporou/page-2. Accessed on $10^{\text {th }}$ September 2011.
} 
and through him many of his descendants produced great warriors. ${ }^{9}$ From a long list of illustrious ancestors whose names are still remembered in the many hapū names of Ngāti Porou, there is perhaps only one person of Ngāti Porou descent who is more widely known and referred to as the father of Ngāti Porou in more recent times - the late Sir Apirana Ngata. ${ }^{10}$

Sir Apirana Ngata was a prominent leader of Ngāti Porou who created a lasting legacy for his people. He served Māoridom with distinction while a Member of Parliament ${ }^{11}$ and he actively worked to build a better life for his people. Ngata's achievements were many. He instigated the building of meeting houses largely in the 1920s to "40s as a catalyst for restoring and revitalizing Māori identity and wellbeing, he was the father of the Māori Battalion for Māori who served in the First and Second World Wars, he compiled and researched Māori waiata (song poetry), later to become known as Ngā Mōteatea, and he instigated farming and dairying initiatives for Māori during the early 1900s.

In many ways, Ngāti Porou's position and stance regarding tribal taonga in contemporary times is an extension of what Apirana Ngata envisioned for Ngāti Porou and Māoridom during his time. ${ }^{12}$ Ngata saw the value of culture and taonga, such as wharenui, waiata and artefacts, as something that helped to uplift the people. Ngata was actively involved in ethnographic fieldtrips and expeditions in 1919-23 to study and record Māori ways of life, including collecting and recording artefacts, songs, photographs and oral recordings. These expeditions became known as the Dominion Museum Ethnographic Expeditions 1919-1923 and involved well-known politicians and anthropologists, such as Elsdon Best, Apirana Ngata, James McDonald and Peter Buck (Te Rangihiroa). The collection of knowledge and taonga formed an important part of Ngata's well-known strategy as expressed by his kupu korero 'E Tipu e rea' and they were used in the Young Māori Party's programme of

9 Ibid. 1. Porourangi's full name is Porou-ariki Mata-tara-a-whare te tuhi māreikura o Rauru.

10 Mahuika, Apirana. 2010. "A Ngāti Porou Perspective". In Weeping Waters: The Treaty of Waitangi and Constitutional Change, edited by Malcolm Mulholland and Veronica Tawhai, 145-163. Wellington: Huia Publishers. Mahuika says that chieftainship and leadership in Ngāti Porou were exercised by male and female alike, as opposed to the general rule of primogeniture through the senior male line. p.146-7. Apirana Ngata passed away on $14^{\text {th }}$ July 1950 .

11 Ngata was a Member of Parliament from 1905 to 1943.

12 The Ngata Lecture series continues in modern times and is a regular feature on Ngāti Porou's calendar of events. 
"economic and cultural invigoration... and to ensure that the ways of their ancestors were brought forward into Te Ao Māori, the contemporary Māori world." 13

Ngata saw that Māori tribal development and identity went hand in hand. Throughout his career he pursued strategies and initiatives that were taonga-related yet developmentfocused. ${ }^{14}$ Ngata had a philosophy and deep conviction that culture lies at the heart of Māori development and his development work focused on the people to advance the social, economic and cultural dimensions. Ngata, for example, "saw development of land by Māori themselves as the best safeguard against alienation." ${ }^{15}$ Ngata saw the breakdown of their culture by colonization and, along with his close friends and colleagues Peter Buck and Henare Balneavis, strove to uplift them.

The tribal authority of Ngāti Porou is Te Rūnanga o Ngāti Porou and the policies and operations of this tribe are examined in this section of the research. The Ngāti Porou tribal authority works to ensure that Ngāti Porou people get all the services for their wellbeing. The Ngāti Porou development model and framework titled 'Ngāti Porou Potential Framework' is closely aligned to the macro-Māori development 'Realizing Māori Potential'16 and has many synergies with Paulin's Ngāi Tahu's Māori development framework, as discussed in Chapter Three.

\section{Ngāti Porou Waitangi Tribunal claim}

The Ngāti Porou Waitangi Tribunal Deed of Settlement was settled between the Crown and Ngāti Porou on $22^{\text {nd }}$ December 2010. This represented two and a half years of direct negotiation, notwithstanding earlier discussions and mandating issues. ${ }^{17}$ In April 2008, the Crown accepted Ngāti Porou's Deed of Mandate and a Te Haeata sub-committee was appointed. The negotiations with the Crown commenced in that same month and all together the Te Haeata representatives met with Crown officials 230 times. $^{18}$

13 Henare, 2007, 100.

14 Some of these included the Ethnological Fieldtrips (1919-1923), involvement in the Polynesian Society, the establishment of the Arts and Crafts Institute in 1926 and the building of over 28 meeting houses throughout New Zealand. See Henare, 2007, 101.

15 Walker, 2001, 76.

16 See Te Rūnanga o Ngāti Porou website.

17 See Annual Report for Te Rūnanga o Ngāti Porou, 2010.

18 See Te Rūnanga o Ngāti Porou Annual Report 2011 (p. 12). 
The settlement package that was successfully negotiated by Te Haeata for Ngāti Porou contained \$123 million in cash and almost 6,000 hectares of conservation land. ${ }^{19}$ An important part of the settlement package was a letter of commitment (LOC) between Ngāti Porou and Te Papa, along with the Department of Internal Affairs, regarding Ngāti Porou taonga held in their care. ${ }^{20}$ The LOC included the words "to facilitate the care and management, access and use, and development and revitalization of Ngāti Porou taonga". ${ }^{21}$ The Te Rūnanga o Ngāti Porou Annual Report for 2011 noted the following: "It contains innovative elements of address which go beyond traditional settlement quantum, aiming to deliver future benefits and value across a diverse range of areas affecting Ngāti Porou economic, social and cultural development. It comprises money, land and relationship arrangements with the Crown." 22

The Ngāti Porou Treaty of Waitangi claim LOC was advanced by the Ngāti Porou Waitangi Claim Negotiating Team Te Haeata and three Government agencies (Archives New Zealand, National Library and Te Papa). The language used in the Ngāti Porou Claim document speaks about the enduring significance of Ngāti Porou taonga: "Ngā taonga tūturu o Ngāti Porou' to the maintenance and development of Ngāti Porou culture."23 The Ngāti Porou vision within the LOC articulates the following" "Ko ngā taonga tuku iho o Ngāti Porou Ngāti Porou taonga, an enduring legacy in perpetuity for Ngāti Porou”. The principles mentioned include Toitū te Mana Atua, Toitū te Mana Whenua, Toitū te Mana Tangata and Toitū te Tiriti o Waitangi.

The strategic direction of Ngāti Porou is clearly seen in the frameworks that are influenced by their specific tribal values as mentioned in their LOC. Mana and its manifestations (i.e. Atua, Whenua and Tangata), along with toitū or enduring, signals to the world that the taonga tuku

19 Te Haeata members included Dr Apirana Mahuika, Rei Kohere, Ned Ihaka, Linda Smith, Selwyn Parata, Kody Pewhairangi and Jock Walker along with four members appointed by Te Rūnanga o Ngāti Porou Whaimutu Dewes, Rob Mcleod, Herewini Te Koha and Matanuku Mahuika (see Te Rūnanga o Ngāti Porou Annual Report 2011 (p. 12)).

20 The Department of Internal Affairs includes Archives New Zealand Te Rua Mahara o Aotearoa and the National Library of New Zealand Te Puna Mātauranga o Aotearoa.

21 See Waitangi Tribunal. 2011. "Ko Aotearoa Tēnei: A Report into Claims Concerning New Zealand Law and Policy Affecting Māori Culture and Identity". Waitangi Tribunal. The Report notes that this is "another expression of partnership" (p.509).

22 Ibid.

23 The meeting was held at the Offices of Rainey Collins Lawyers in Wellington. 
iho o Ngāti Porou are still important and significant in today's world. ${ }^{24}$ For Mahuika, all mana are 'taonga tuku iho' or 'inherited mana' derived from ancestors through whakapapa. ${ }^{25}$

Ngāti Porou's position regarding taonga held in museums is stated emphatically in the Ngāti Porou Deed of Settlement and was also noted in the Waitangi Tribunal Wai 262 Report on New Zealand law and policy affecting Māori culture and identity. ${ }^{26}$ The Chairperson of the Rūnanga o Ngāti Porou, Apirana Mahuika, called for the return to Ngāti Porou of the guardianship and control of the tribe's taonga tūturu. ${ }^{27}$ Like the positioning statements of Ngāti Porou's LOC, Mahuika makes the statement that Ngāti Porou taonga, irrespective of age, form an important dimension of Ngāti Porou cultural heritage and identity. The Māori terms 'taonga tūturu' and 'toitū' that form the LOC in Ngāti Porou's claim express the continuing significance and importance of Ngāti Porou taonga for Ngāti Porou people. Mahuika also reminds us that there is a great positive with repatriation in that it helps to educate and inform Ngāti Porou about their tribal taonga.

For Ngāti Porou, "Repatriation is about our people and us. It is about informing, educating, and introducing our own taonga to us and our uri." ${ }^{28}$ The importance of taonga, whether they originated in the $1800 \mathrm{~s}$ or in more recent times, makes no difference to Ngāti Porou, as they are still regarded as part of their cultural heritage: "a meeting house - 'which is typically named after and represents an ancestor of the community to which it belongs' and because of this symbolism, 'clearly embodies notions of tapu, mauri, ihi, wehi and mana associated with that community and that community's culture, heritage and identity' - can be a taonga regardless of whether it is carved in 1840 or $2007 .{ }^{29}$

For the Ngāti Porou claimants, their tribal taonga, whether physical taonga like whakairo or weavings, manuscripts, photographs, maps or intangible heritage such as waiata and oral recordings, are of 'enduring significance' to Ngāti Porou. They are just as important today as they were in former times. There were many Waitangi Tribunal claims that incorporated cultural redress provisions, including taonga held in museums, such as the waka tūpāpaku in

24 This supports the writing of Bishop \& Tiakiwai (2002).

25 See Mahuika, 2010, 148-9.

26 See Waitangi Tribunal, 2011, p.497.

27 Mahuika feared that taonga held in Crown ownership could be sold if they were privatized. This stance was also adopted in the creation of the new Museum of New Zealand Te Papa Tongarewa where Apirana Mahuika was the Chair of the Māori Advisory Group 'Ngā Kaiwawao'.

28 Ibid.

29 Ibid. 501. 
the Te Roroa claim, ${ }^{30}$ but the Ngāti Porou claim incorporated an innovative LOC with three large institutions that spoke directly to the 'enduring significance' of Ngāti Porou taonga to Ngāti Porou tribal identity and history.

Clearly, Ngāti Porou value their tribal taonga and see them as representations of their ancestors. Ngāti Porou have a continuous history of and commitment to their cultural heritage, as evidenced by the building of meeting houses throughout the nineteenth and twentieth centuries, the return of Hikurangi mountain, and the value placed on the language and arts. The return of the Ngāti Porou tribal identity marker Hikurangi maunga (mountain) to Ngāti Porou in 1999, along with its legal title, was a significant tribal event. Te Rūnanga o Ngāti Porou website notes that the return of Hikurangi was an important part of Ngāti Porou's future development and quest for self-determination. ${ }^{31}$

The Waitangi Tribunal Wai 262 Report was released in 2011 and noted that kaitiaki are those who have a special relationship with taonga and that this right gives rise to an obligation and corresponding right to protect, control, use, preserve, or transmit the taonga itself and also the relationship of kaitiaki to the taonga. ${ }^{32}$ This view was fully supported and advanced by Ngāti Porou in their Waitangi Tribunal claim.

An example of the importance of contemporary Ngāti Porou tribal taonga to Ngāti Porou tribal identity can be seen in the Maui carvings on Hikurangi Mountain. In preparation for the celebrations to herald the dawn of the new millennium, new carvings were commissioned by Te Rūnanga o Ngāti Porou to be placed on top of Hikurangi. How these Maui carvings are recognized and promoted within Te Rūnanga o Ngāti Porou reflect their importance as symbols of Ngāti Poroutanga and their significance in relation to Ngāti Porou tribal development. The Maui carvings feature in visual imagery on the Te Rūnanga o Ngāti Porou website and have become iconic of Ngāti Porou identity and culture since that time. The following is included on the Te Rūnanga o Ngāti Porou website under the heading of tourism:

Since the birth of this great land, legends which extol the sacredness of Hikurangi have nurtured the minds and hearts of the descendants of Maui-Tikitiki-a-Taranga who is credited with many great feats that testify to his physical and intellectual prowess. His

30 The Te Roroa Claim Report (1992) included waka tūpāpaku or burial chests that were taken during the 1870s and sold and taken to museums. See Chapter 6: Taonga (Sacred Treasures).

31 See Te Rūnanga o Ngāti Porou website.

32 See Waitangi Tribunal, 2011, p.7. 
greatest exploit was fishing up the North Island of Aotearoa-New Zealand, known to all Māori as Te Ika a Maui (the great fish of Maui). ${ }^{33}$

1000 metres above sea level on Hikurangi Mountain are nine carved Whakairo (sculptures) depicting Maui-Tikitiki-a-Taranga and his Whānau (family). The massive Whakairo are a legacy for the future generations and a tribute to the cultural heritage and artistry that has evolved within Ngāti Porou. ${ }^{34}$

Apirana Mahuika has long argued for iwi to be fully involved in the affairs concerning their tribe and if they are not, then this is just a continuation of colonization. Mahuika made the following comment at the Te Tairāwhiti Wānanga on Cultural Heritage held at Waihirere, Gisborne, in June 2002 with regard to museums and what they do: "The process of colonization will never end unless the process of Rangatiratanga is acknowledged and respected." 35 When Monty Soutar, a former CEO of Te Rūnanga o Ngāti Porou, was asked what to him constituted Ngāti Porou identity and Ngāti Porou development he mentioned the importance of whakapapa and language:

I think language is a key and I think without your language, which is really how you convey your identity, I think your identity is weakened somewhat and I think that is critical. That is not to say that you can't have your tribal identity without the language but it is a big help.

I think whakapapa is critical, knowing your whakapapa. I think whakapapa is a really important part of identity. And then umm I think the tribal icons like your mountain and your river and things like that and down to hapu those are really important.

Yes and I think also if you are from Ngāti Porou, waiata and haka play an important part too. And so it's the one tribe in this country who without a practice can stand up and do an item. Paikea for example, and Ruaumoko and there are just very few tribes who can actually do that off the cuff. You have had no practice and you don't even know the people but they all know those items and that is about tribal identity again. ${ }^{36}$

Clearly, for Soutar, whakapapa, knowledge of the language, and knowledge of waiata and sung poetry are important expressions of Ngāti Porou identity. In relation to Ngāti Porou taonga, Soutar believes that the appropriate context for Ngāti Porou taonga is when they are returned back with their people as only then they become 'alive' when he stated: 'they should be back within the Ngāti Porou territory at least and that its relevance, it only becomes a

33 See Te Rūnanga o Ngāti Porou website under the heading of tourism.

34 Ibid.

35 This hui was organized by the Tairāwhiti Museum, Gisborne, in partnership with National Services Te Paerangi of Te Papa. Mahuika (2010) makes similar comments in 2008 in relation to the deed signed between the Crown and Ngāti Porou for the foreshore and seabed negotiations. Tradition and tikanga were essential to the determination and identification of Ngāti Porou mana and rights - the mana motuhake o Ngāti Porou to ensure that Ngāti Porou made the decisions and not someone else (p.157).

36 Monty Soutar interview, $18^{\text {th }}$ August 2011. 
living taonga when it's among the people to whom it belongs ... they are part of you no matter where they are and I think one of the sad things is to go into the strong rooms of museums as I did in Auckland and see Ngāti Porou taonga in there that is locked away and is out of its context and people." 37

Soutar also reminds us that there are harsh realities in just surviving and looking after your whanau when it comes to such things as culture, as he says: "That means that if you are going to strengthen identity first you have got to put bread on the table. And that means employment. You have to get those things right because unfortunately culture comes second place to that for families." 38

Building a Ngāti Porou archive and research centre where everything about Ngāti Porou can be accessed is something that Ngāti Porou should do, according to Soutar. This idea is in line with Ngāti Porou cultural aspirations that see Ngāti Porou taonga tuturu as an enduring legacy for their people. The Ngāti Porou claim adopted the Māori words 'taonga tūturu' and 'toitū' to express the continuing significance of these treasures for their people.

\section{Te Rāwheoro Whare Wānanga}

\section{Te Aitanga-a-Hauiti - Ka tipu te whaihanga, e hika, ki Ũawa \\ Me ko Manutangirua ko Hīngāngāroa \\ From Manutangirua descends Hīngāngāroa}

Ka tū tōna whare, Te Rāwheoro, $e$

Who built his house of learning Te Rāwheoro

\section{Ka tipu te whaihanga, e hika, ki Ūawa}

Proliferating the arts from Uawa ${ }^{39}$

Te Aitanga-a-Hauiti has been selected as a Māori tribal case study because they have undertaken a number of tribal art and taonga projects that have focused on Te Aitanga-aHauiti art, history and culture over the last 25 years. Te Aitanga-a-Hauiti have organized their own tribal exhibitions and art projects, held wānanga on art practices and undertaken innovative digital repatriation projects concerning their tribal taonga held in museums and institutions both in New Zealand and throughout the world. The tribe has reasserted control

37 Ibid.

38 Ibid.

39 These words are taken from the waiata tangi of Rangiuia of Te Aitanga-a-Hauiti for his son Tuterangiwhaitiri. The words show the historic association of the Te Rāwheoro Whare Wānanga and the rich art traditions that descended down from Hingāngāroa to Te Rāwheoro. (See also Ngā Mōteatea Part One, song 66 pp.294-297. 2004. Auckland: Auckland University Press). 
and influence over many of their tribal taonga that have been scattered and dispersed to the four winds through the process of colonization, western imperialism and globalization. Te Aitanga-a-Hauiti have embraced modernity, yet maintained strong links to their past and, in particular, the rich artistic traditions that emanated from the Te Rāwheoro Whare Wānanga or House of Learning in the eighteenth and nineteenth centuries.

Te Aitanga-a-Hauiti is not a large tribe, but their drive and dedication to enliven the legacy of the Te Rāwheoro Whare Wānanga in the modern world is well known. The tribe has drawn from their rich cultural and artistic traditions of the past to shape and inform their future, as evidenced by the adoption of significant tribal words, concepts, knowledge traditions and events from Te Aitanga-a-Hauiti's historical past. The words of the well-known waiata tangi of Rangiuia for his son Tuterangiwhaitiri at the start of this chapter remain a strong guiding ethos for tribal descendants today and are testament to the importance of the Te Rāwheoro Whare Wānanga.

As a tribe Te Aitanga-a-Hauiti have reached out and embraced new technologies and created mutually beneficial two-way relationships with a range of organizations to develop their present development initiatives and future cultural heritage aspirations. The relationship with their tribal taonga spans centuries and their engagement and participation in tribal projects provide a good opportunity to examine the nature of the relationship between Te Aitanga-aHauiti tribal identity and tribal development and the role and place their tribal taonga play in achieving inter-generational sustainability in economic, social and cultural terms.

The Te Aitanga-a-Hauiti tribe are the descendants of their eponymous ancestor Hauiti and reside at Ūawa, Tolaga Bay, on the East Coast of the North Island, New Zealand. Today there are around 5000 tribal members affiliated to Te Aitanga-a-Hauiti with a large majority living outside the traditional tribal lands. ${ }^{40}$ Hauiti was the youngest son of Hingāngāroa, the renowned tohunga, and Iranui, the sister of Kahungunu, the eponymous ancestor of Ngāti Kahungunu. ${ }^{41}$ Hauiti was believed to have been born about the year 1575 . Hingāngāroa was a skilled artisan, seer, tohunga whakairo or master carver, a builder of waka, and was believed to have been born in about $1550 .{ }^{42}$ Hingāngāroa had great knowledge and talents and these

40 See Ngata, Wayne, Hera Ngata-Gibson, and Amiria Salmond. 2012. "Te Ataakura: Digital taonga and cultural innovation”. Journal of Material Culture no. 17 (3):229-244., 232. The majority of the tribal members are under 25 years old and around 700 live within their tribal boundaries. McCarthy notes that there are no less than 30,000 'Hauitians' who live outside the tribal rohe (McCarthy 2011, 226).

41 Ngāti Kahungunu is a large tribe that extends from north of Wairoa, through Heretaunga, to the Wairarapa.

42 See "Te Aitanga-a-Hauiti the Descendants of Hauiti." Te Ao Māori i Te Tairawhiti,7" December 20072007. 
were passed down through the ancestral lines to eventually become the Te Rāwheoro Whare Wānanga or House of Learning. ${ }^{43}$ This whare wānanga flourished for many centuries and was widely acclaimed and known throughout the land. Te Rāwheoro would become one of the leading whare wānanga for the arts in the Tairāwhiti region, extending as far south as Wairarapa. $^{44}$

Te Aitanga-a-Hauiti tribal identity has strong identifications to the whenua and landmarks of the Tolaga Bay area. This is clearly seen on the Facebook site for Te Aitanga-a-Hauiti where the pepehā or tribal proverb is given:
Ko Tereanini te waka
Ko Titirangi te maunga
Ko Ūawanui-a-Ruamatua te awa
Ko Ruakapanga ki Hauiti te marae
Ko Hauiti te tangata
Ko Te Aitanga-a-Hauiti te iwi ${ }^{45}$

The Te Rāwheoro Whare Wānanga became closely associated with the development of the Te Rāwheoro carving style/tradition and the effervescence of this flourishing carving tradition was seen by those on Captain Cook's voyage to Tolaga Bay in 1769. Cook sailed to Uawa after first calling in to Turanganui (Gisborne) and spent a week in a small bay, interacting with the natives. While there, they saw an elaborately carved pātaka (storehouse) and wharenui (meeting house) and they also visited Pourewa Island where they were gifted a carved poupou by the tribal ancestress, Hinemātioro. This poupou was taken aboard the Endeavour and was taken back to England where Benjamin John Frederick Miller completed an engraving of it. This poupou has become known as Te Pou o Hinemātioro and until recently was thought to be lost to the four winds. ${ }^{46}$

There were many tohunga associated with the Te Rāwheoro Whare Wānanga, but Rangiuia was its last tohunga, priest and tutor. The words at the start of this chapter speak about the proliferation and vitality of arts from Ūawa and the Te Rāwheoro Whare Wānanga. Te Rāwheoro officially closed in the mid-nineteenth century, but the traditions and teachings

43 Ibid.

44 The well-known Wairarapa tohunga, Te Matorohanga, attended Te Rāwheoro.

45 See facebook address: http://www.facebook.com/pages/Te-Aitanga-aHauiti/147185551958818?id=147185551958818\&sk=info. Accessed on $18^{\text {th }}$ February 2013.

46 This carved poupou was found in the Tubingen University, Germany, by Anne Salmond and since that time Te Aitanga-a-Hauiti has visited the university museum to see their tribal taonga and form relationships with the museum. 
continue to live on in the community of Ũawa, Tolaga Bay. ${ }^{47}$ As noted by tribal descendants in 2007, Te Rāwheoro may be gone, but the tradition of the arts, originated by Hingāngāroa, continues to flourish among his present-day descendants. $" 48$

How Te Aitanga-a-Hauiti see, experience and know the world to be is at the heart of this research. The research into this community of Ūawa is in itself a reflection of the world and the reality of Te Aitanga-a-Hauiti, as known and experienced by them. Te Aitanga-a-Hauiti have reaffirmed their whakapapa links with their taonga and reasserted authority on their taonga and why they are important. This tribal worldview and reality of Te Aitanga-a-Hauiti reflects both an ontological perspective and a kaupapa Māori discourse which is critical to the questions and propositions of this research. With regard to kaupapa Māori critical discourse, Graham Smith says that it is about "The philosophy and practice of being and acting Māori." ${ }^{49}$ Kaupapa Māori is about cultural relevance and meaning and the right of Māori to determine their own future in their own way. Adopting a kaupapa Māori research methodology has meant that the tribal understandings are given authority on their own terms and that the traditions and customary values are accorded primacy in understanding the role of tribal taonga for their tribe. As noted by Bishop:

To assert authority over their things is thus to make claims of ontological as well as political import - that is, claims about the fundamental ways in which the world is organized, and how its elements are connected, as well as about which of those connections matter most. ${ }^{50}$

The art and cultural initiatives that Te Aitanga-a-Hauiti have embarked on over the last 30 years affirm the ongoing continuity of their rich artistic legacy that emanated from $\mathrm{Te}$ Rāwheoro. This tribe has been actively involved in exhibitions and art projects that relate directly to their tribal history and identity and embarked on innovative taonga projects that have focused on cultural revitalization and renewal. Developing collaborative relationships and partnerships with institutions to aid their cause was a vital strategy. The knowledge of the Te Rāwheoro Whare Wānanga and its teachings has played, and continues to play, a key role

47 See Ngata, et al, 2012, 231.

48 See "Te Aitanga-a-Hauiti the Descendants of Hauiti." Te Ao Māori i Te Tairawhiti, $7^{\text {th }}$ December 2007.

49 Cited in Bishop, 1998, 201.

50 Ibid, 230. 
in helping to shape Te Aitanga-a-Hauiti's future tribal development: "Hauiti's descendants have been gathering remnants of that body of knowledge together to underpin their tribal development."

An example of this rich legacy is Toi Hauiti, a working group of the Te Aitanga-a-Hauiti Centre of Excellence, that is based in Ūawa, Tolaga Bay. This group has been instrumental in organizing art projects in association with the Tairāwhiti communities for the benefit of Te Aitanga-a-Hauiti for some years. Some of the more notable projects include:

- $\quad$ Te Pou o Te Kani Exhibition 2003/04

- 2006 - first tele-tangi - broadcast live on the internet

- 2006/07 - Ru-Ūawa, a biennial New Year's Eve concert that celebrates Māori music.

- Toi Hauiti involvement in the Pasifica Styles exhibition at the University of Cambridge Museum of Archaeology and Anthropology in 2008

- $\quad 2009$ - Pat Ngata wanted to be present in person as a hologram at his tangihanga

- $\quad$ 2010/11 - Master art wānanga programme with Alex Nathan

- Transit of Venus celebrations and workshop in $2011 / 12^{52}$

\section{Te Pou o Te Kani exhibition}

The Te Рои о Te Kani exhibition was one of the first exhibitions that Te Aitanga-a-Hauiti organized which was on show from October to December in 2003 in Paratene Ngata's house in Ūawa, Tolaga Bay. ${ }^{53}$ The project involved tribal artists and close relationships were established with a number of institutions, including the Tairāwhiti Museum Trust Board, the local Historic Places Trust, Auckland Museum and the Museum of New Zealand Te Papa Tongarewa. ${ }^{54}$ The exhibition included lectures from historians and well-known personalities and took the form of a whare taonga (tribal treasure house) and tourist attraction where people were encouraged to "learn about Te Aitanga-a-Hauiti's identity as an iwi and the tribe's proud artistic heritage." ${ }^{55}$ For Mark Kopua, a prominent artist of the tribe, the Te Pou $o$ Te Kani exhibition was important because the idea was brought to him from the next

51 Ibid, 231.

52 See Toi Hauiti at Māori Art Market 2011 promotional pānui. See also McCarthy, 2011, 225-228.

53 An earlier Te Aitanga-a-Hauiti exhibition titled 'Ka tipu te whaihanga' was held at the Tairāwhiti Museum in 2003, which featured carved, woven, and contemporary artworks. A database of Te Aitanga-a-Hauiti taonga was established for this exhibition which laid the platform for later projects such as Te Whatakōrero. (See Ngata, et al, 2012, 236.).

54 Ibid.

55 Ibid, 234 
generation who were concerned that they were unable to access their tribal taonga. From teaching at the local Tolaga Bay Area School, Mark also discovered that very few of the younger generation knew about the Te Rāwheoro Whare Wānanga. ${ }^{56}$

The primary objective of Te Pou o Te Kani was to "provide opportunities to develop tribal capability through the exhibition gateway, so that Te Aitanga-a-Hauiti people could identify and pursue new educational and economic pathways." ${ }^{57}$ Also included in these new pathways was the engagement in new technologies to serve their ends. The developmental dimension was always at the forefront of their tribal thinking. Mark Kopua noted that Te Pou o Te Kani was a focal point and opportunity for the people of Te Aitanga-a-Hauiti to learn about themselves. Following from this was a desire to see and reconnect with their taonga and then to learn about their history and heritage, like that of Te Rāwheoro. As Kopua says:

It's one of the focal things of Te Pou a Te Kani was that our people had the opportunity to learn about themselves... And I knew that the kids at home had no idea of the Rāwheoro heritage and history and so here we were starting to come together to learn about ourselves. Start teaching ourselves our history, and giving ourselves a strong footing to being able to push in a direction that you think is right for you. ${ }^{58}$

\section{Te Whatakōrero}

Following from this tribal exhibition in 2003 was Te Whatakōrero, a research project aimed at locating Te Aitanga-a-Hauiti taonga in museum collections within New Zealand. This was soon broadened out to include a more "comprehensive Kete (kit) of Te Rāwheoro/Te Aitanga-a-Hauiti korero (knowledge, talk), histories and images within the guardianship of 'Tangata Whenua'." 59 The Te Whatakōrero project became an interactive CD-ROM created to bring together Te Aitanga-a-Hauiti taonga for the benefit of their people. The development of the digital repository or storehouse of knowledge was seen as critical for the descendants of Hauiti who were historically deprived of access to taonga that belonged to them.

The Te Whatakōrero project is important to this research dissertation because it affirms the important role that Te Aitanga-a-Hauiti taonga play in building tribal pride and, with this, creating a sound foundation and platform for their tribal development future. The reconnection and reunification with their taonga was an important dimension that

56 See Mark Kopua interview, $23^{\text {rd }}$ September 2011.

57 Ibid, 236.

58 Mark Kopua interview, $23^{\text {rd }}$ September 2011.

59 Ngata, et al, 2012, 236. 
underpinned their tribal development: "Reuniting Hauiti people with their taonga was and continues to be a powerful tool in fostering self-belief and tribal pride within the community - an important platform underpinning tribal development. ${ }^{, 60}$ The Te Whatakōrero project started in 2005 and was focused down to include the tribal taonga held in five museums. As noted by tribal members, the digital repatriation became a fast and practical solution for reconnecting Te Aitanga-a-Hauiti with their heritage. ${ }^{61}$

The traditions of the Te Rāwheoro Whare Wānanga are seen throughout the tribe's development strategies and practices. Education, cultural revitalization and building strategic relationships remain important to Te Aitanga-a-Hauiti. The continuing importance of the traditions of the Te Rāwheoro Whare Wānanga for Te Aitanga-a-Hauiti is very evident in the operations of Toi Hauiti and the tribe. On the promotional brochure of Toi Hauiti at the Māori Art Market 2011, for example, the following is given:

Over the past decade, Toi Hauiti has worked together with the Tolaga Bay and Tairāwhiti communities, as well as national and international institutions to celebrate and reaffirm the body of artistic and economic knowledge promoted by the house of learning of Hingāngāroa, Te Rāwheoro, captured in the maxim, 'Kia tipu te whaihanga e hika ki $\bar{U} a w a-a n d ~ s o ~ d i d ~ i n n o v a t i o n ~ a n d ~ c r e a t i v i t y ~ f l o u r i s h ~ i n ~ \overline{U a w a ' ~}{ }^{, 62}$

For Wayne Ngata, the legacy of Te Rāwheoro is profound for the tribal descendants of Te Aitanga-a-Hauiti, as it forms the basis for their engagement with themselves that underpins and shapes their future development:

So the legacy of Te Rāwheoro drives what we as Te Aitanga-a-Hauiti do and whatever initiatives we are involved in as far as art knowledge nga whakairo, nga korero toi or stem from the legacy of Te Rāwheoro. So that's the basis of our engagement with ourselves more than anything else in terms of our art. So in recent times, by recent I mean in the last 15-20 years, a number of us have become more involved in revisiting that legacy, re-establishing that tradition and promoting that as a basis for development for Te Aitanga-a-Hauiti... It's not about how you fix up the negatives but it's rather about how you promote the positives potential that Māori people have, that Te Aitangaa-Hauiti descendants have, and so that's the driver for us and Te Rāwheoro underpins those sorts of things. ${ }^{63}$

60 Ibid, 236.

61 Ibid, 237.

62 See Toi Hauiti at Māori Art Market 2011 promotional pānui.

63 Wayne Ngata interview, $19^{\text {th }}$ December 2011. 


\section{Te Kahawhitia}

A further example of the legacy of Te Rāwheoro is Te Kahawhitia, the strategy for artistic and economic revitalization of Te Aitanga-a-Hauiti. The name 'Te Kahawhitia' comes from the historical past where a battle was fought by the tribe's eponymous ancestor where he ordered the closing of a seine net to take both the fish and those that were plundering it. ${ }^{64}$ The name resonates with meaning and significance for Te Aitanga-a-Hauiti and its adoption as a name for an arts strategy for cultural and economic revitalization is a further tangible expression in how Te Aitanga-a-Hauiti express the teachings and traditions of the Te Rāwheoro Whare Wānanga in the contemporary world. The aim of Te Kahawhitia was "to develop, enhance and build on relationships with museums and archives in New Zealand and abroad that hold Te Aitanga-a-Hauiti taonga - manifestations of Hingāngāroa's teachings in ways that will provide strong new foundations for present and future tribal development." 65

The diagram below emphatically shows the relationship of the Te Rāwheoro Whare Wānanga to Te Aitanga-a-Hauiti and their contemporary development future with respect to art, culture and economic development. The whakapapa format shows the continuum of the past with the future and was written by tribal members.

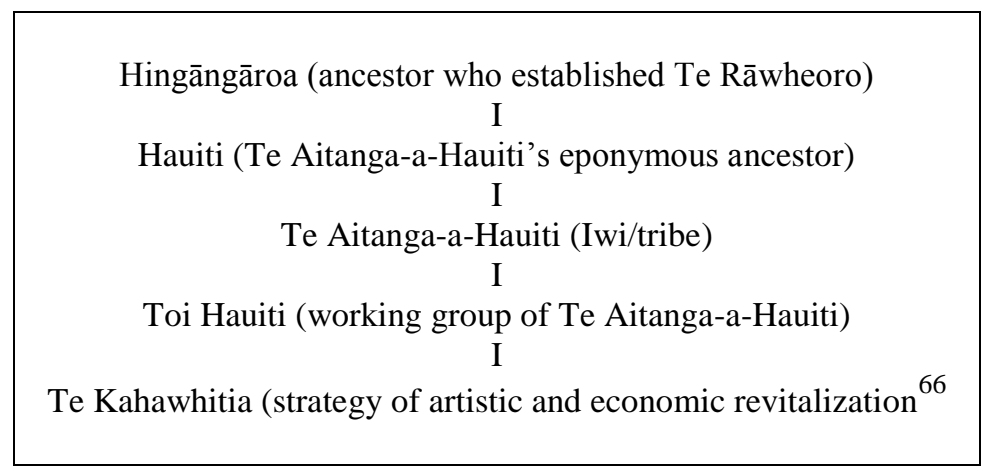

\section{Te Kapuārangi}

The adoption of the Te Rāwheoro Whare Wānanga and its teachings for the modern community of Te Aitanga-a-Hauiti tell us that their tribal taonga continue to act as powerful symbols from which to teach and educate tribal descendants on their tribal history and identity. Revisiting, rekindling and restoring knowledge of Te Aitanga-a-Hauiti taonga has been a direct initiative that followed the repatriation of the mere pounamu Te Kapuārangi in

Ibid, 234.

65 Ibid.

66 See Ngata, et al, 2012, 235. 
May 1999. This tribal heirloom was taken from a tribal burial ground by a local school teacher at Karaka, north of Tolaga Bay, who found it when it was exposed by the sea. ${ }^{67}$ The return of this tribal taonga, as noted by Spedding, generated several collaborative ventures between Te Aitanga-a-Hauiti and the Tairāwhiti museum. ${ }^{68}$ What was important about the return of this tribal taonga was that it "rekindled awareness among the tribe of Te Rāwheoro's legacy."69

As a direct result of the return of Te Kapuārangi, Toi Hauiti was formed in the following year "to study and promote this distinguished artistic heritage." 70 The literature has seen an increase in interest in the examination of museums and their relationships with Māori. ${ }^{71}$ Establishing meaningful relationships with museums has been an important strategy for Te Aitanga-a-Hauiti. The tribe's relationship with the Tairāwhiti Museum has matured and this was in large part due to the repatriation of the mere pounamu Te Kapuārangi. ${ }^{72}$ Adopting Peers and Brown's recognition of the importance of creating new relationships with source communities, Te Aitanga-a-Hauiti have undertaken to create their own 'tribal praxis' built on the knowledge and rich artistic traditions of Te Rāwheoro, but which is relevant to their needs in the present. Creating relationships with museums, universities and organisations is seen by Te Aitanga-a-Hauiti as an important expression of this Hauitian philosophy.

The Te Rāwheoro Whare Wānanga is not considered an historic relic and relegated to the distant past, but rather Te Aitanga-a-Hauiti has taken its strong traditions and practices to help shape and inform the tribe's economic and cultural future. This is clearly seen in the promotion pānui when describing the 2011 Toi Hauiti exhibition being planned for the Māori Art Market at the Te Rauparaha Arena in Porirua:

The exhibition "Toi Hauiti - Living The Legacy" celebrates the art economy of Te Aitanga-a-Hauiti through the legacy of Te Rāwheoro, one of its foundation houses of learning. We celebrate this by highlighting and showcasing excellence in our art forms, innovation in our artistic expression and achievement of our artists as they develop our economic heritage. $^{73}$

67 Ibid.

68 See Spedding, Mike. 2006. “Te Aitanga a Hauiti and the Tairawhiti Museum”. Te Ara: Journal of Museums Aotearoa no. 31 (1):27-31. 29.

69 Ngata, et al, 2012, 234.

70 Ibid.

71 See Butts, 2003; Cameron, 2000; McCarthy, 2004; Tapsell, 1998.

72 See Spedding, 2006, 28-29. Ngata, et al, 2012, 234-236.

73 Ibid. 
Te Aitanga-a-Hauiti have been separated, alienated and deprived of access to their ancestral treasures in what has been described as a mix of mono-cultural, western-nature museum institutions, and the tyranny of geographical distance. There was no doubt that these initiatives were first and foremost for the benefit of Te Aitanga-a-Hauiti. ${ }^{74}$ The involvement and engagement of Te Aitanga-a-Hauiti in the latest technologies has also been a way to induct the younger Te Aitanga-a-Hauiti people with regards to their cultural inheritance and be a waka or vehicle for mātauranga Māori and mātauranga Hauiti. For Te Aitanga-a-Hauiti artists, such as John Walsh, Robyn Kahukiwa, Mark Kopua and Takirirangi Smith, technologies "provide compass points for directing tribal innovation and development": ${ }^{75}$

Alongside their artists, the people of Hauiti have embraced the power of digital technologies to enliven old connections, strengthening the ties of whakapapa (kinship) between their far-flung members in ways that are continuous with much longer-standing practice ... Hauiti have led the way in the experimental use of digitization to promote and uphold principles such as whanaungatanga (relationship building) and manaakitanga (hospitality). ${ }^{76}$

\section{Te Ataakura}

Te Aitanga-a-Hauiti are one of the major tribal leaders in digital and virtual repatriation initiatives. Te Aitanga-a-Hauiti clearly want to reconnect and re-establish authority over elements of their cultural identity and artistic expressions. A good example of this is the $\mathrm{Te}$ Ataakura Project that concerns digital repatriation where the tribe plans to reassemble their dispersed taonga throughout the world with the latest technologies. Te Aitanga-a-Hauiti once again looks to the past to help inform and shape the future. Embracing new technologies is an important dimension for Te Aitanga-a-Hauiti and Te Ataakura is yet another example of the philosophy of the Te Rāwheoro Whare Wānanga and how the knowledge and traditions that underpin it continue to shape and inform the future development of Te Aitanga-a-Hauiti. As noted by tribal descendants: "Hauiti's descendants have been gathering remnants of that body of knowledge together to underpin their tribal development.",77

In describing the benefits of this project, Dr Wayne Ngata noted the importance of accessibility to their people and the embodiment of the words of his ancestors:

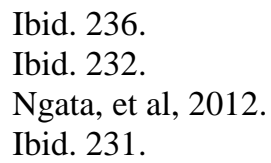


Ka tikina atu e matou i a matou tamariki otira te hunga pakeke hoki. Hei ahuatanga whakamahi ma tatou kia eke ano i runga o tera o tatou tipuna e tipu e rea i nga ra o tou ao. Na koianei te hao.

We want our children and our old people to access this knowledge through this new technology and embody the words of our ancestors who said we must grow with the times. $^{78}$

For Te Aitanga-a-Hauiti it was important to foster enduring relationships with the guardians who care for their taonga. ${ }^{79}$ Like many of the other names and projects that Te Aitanga-aHauiti have created to describe their contemporary art and cultural projects, the name Te Ataakura comes from their rich historical past. Te Ataakura means 'the red clouds of dawn' and is an ancestor who descends from the eponymous ancestor Hauiti. ${ }^{80}$ The importance of the Te Rāwheoro Whare Wānanga is very apparent with the Te Ataakura project as, for the project team, Te Ataakura was underpinned with the kōrero taken from the lament of Te Rangiuia for his son Tuterangiwhaitiri:

It is underpinned by the maxim kia tipu anō te whaihanga e hika ki roto o Ūawa -'and so knowledge creation and innovation will once again thrive in Üawa', extracted from the lament of Rangiuia for his son Tūterangiwhaitiri: a whakataukī or saying that promotes mutual understanding, exchange and the dissemination of beneficial knowledge. This chant indeed provides a manifesto for Toi Hauiti's work in general that may be summed up as 'Educate, Innovate, Catalyze, Change', a culture of dynamism that naturally lends itself to the experimental deployment of new technologies. The name Te Ataakura also invokes 'the exhibiting of valued forms using light', hence its use for this digital project. $^{81}$

It is clear that Te Aitanga-a-Hauiti's tribal taonga occupy a special place in their present contemporary world, as they are considered physical embodiments of the body of knowledge and traditions of Te Rāwheoro. This is expressed by Wayne Ngata when asked about the importance of tribal taonga:

From my point of view the taonga and artefacts and those sorts of things are in essence a physical embodiment of that body of knowledge and so to connect with them is to connect with that body of knowledge, connect with the people who held that body of knowledge to connect with that legacy of Te Rāwheoro all those other houses of learning

78 Te Karere Māori News, 1st February 2010 'Te Aitanga-a-Hauiti uses 3D technology to access their traditional taonga.'

79 Ibid. 238.

80 Ibid. 240. The writers say that the name also invokes 'the exhibiting of valued forms using light' and is a name quite appropriate for the digital project.

81 Ibid. 240. 
that were part of our community and to maintain that. So they become the icons, the physical embodiment and individual embodiment of what we are trying to develop., 82

When Wayne Ngata was asked whether Te Aitanga-a-Hauiti have any kupu (words) or concepts that frame or refer to their tribal taonga or cultural heritage, his response was that this was contained within the Waiata Mōteatea of Te Rangiuia. Clearly Te Rāwheoro is an important taonga for Te Aitanga-a-Hauiti descendants today as expressed by Ngata, "I suppose more than anything else it is taken from the waiata Rangiuia mo te kaupapa mo Te Rāwheoro - kia tipu te whaihanga e hika ki Ūawa." ${ }^{83}$ When Mark Kopua was asked the same question, his reply was the same as Wayne Ngata's: "the one that we use for Te Pou-a-Te Kani and the other successful exhibitions which was Uawanui, Pou maia, and Ru-Uawa was 'Ka tipu ano te whaihanga e hika e' which is basically creativity will grow again or grows in Uawa." $" 84$

Concerning Māori tribal development, Kopua believes that it is when the community and iwi do things together to uplift or enhance their own tribal identity. Having our own cultural and historical components, such as the legacy and contribution of Te Rāwheoro, in the development of the arts has real value. Kopua believes that their culture and history puts them in good stead for the future and that it is this dimension that has value to them:

Our value and what we see as important and valuable to us is really our culture. And so the only thing that is purely ours and of value is our history and our culture. And so we decided that we would use that as the catalyst to push us forward... And so it's like aeons, long, long past history to the now and the idea we had was to push it forward to a long, long, long future. ${ }^{85}$

For Te Aitanga-a-Hauiti, their tribal taonga form an important pillar and foundation for who they, where they have come from and where they are going to in the future. The worldview of the tribe sees the reunification with their tribal taonga as an important foundation and source of pride and tribal identity. The Te Rāwheoro Whare Wānanga and its knowledge traditions remain an important taonga for the tribe in enlivening their rich artistic and cultural legacy for the benefit of today's descendants. Te Aitanga-a-Hauiti taonga occupy a core position with regard to their inter-generational sustainability in economic, social and cultural terms. Te Aitanga-a-Hauiti taonga are in themselves considered manifestations and physical

Wayne Ngata interview, $19^{\text {th }}$ December 2011.

Ibid.

84 Mark Kopua interview, $23^{\text {rd }}$ September 2011.

85 Mark Kopua interview, $23^{\text {rd }}$ September 2011. 
embodiments of Hingāngāroa's teachings and knowledge traditions and this provides living connections with the past, present and future. Te Rāwheoro and the waiata oriori for Tuterangiwhaitiri also provide a foundation for a culture of dynamism.

\section{Rongowhakaata - Te Hau ki Türanga wharenui}

\section{Ko taku tīpare whakarei, taku Manawa, manapou o te iwi}

The Te Hau ki Türanga carved meeting house is an important symbol of Rongowhakaata's past, present and future. Te Hau ki Türanga was forcibly confiscated by the Crown without the consent of its tribal owners in 1867. The confiscation of Te Hau ki Türanga at this time along with its later 'museum' history in the National Museum in Wellington is both a symbol of past Crown injustices to Rongowhakaata and the basis for the future development of Rongowhakaata tribal art, culture and identity.

Te Hau ki Türanga involves a large number of people and organisations amidst shifting contexts over a long period of time. As noted by McCarthy, Te Hau ki Tūranga is a classic example of what Nicholas Thomas calls an 'entangled object' ${ }^{86}$ Clear today is that this entanglement has been unraveled by Rongowhakaata with Te Hau ki Türanga's mana being reasserted by its people, for its people. The words cited above express some of the feelings Rongowhakaata have for their tribal treasure today as they were composed for a haka and performed by the Rongowhakaata Kapa Haka group, Tu Te Manawa Maurea, at the Te Matatini 2011 Māori Performing Arts national competition in Gisborne. The haka composition is a reaffirmation of the mana of Te Hau ki Türanga and its ability to transform its people from the scars and pain of the past.

Unlike the Ngāi Tahu and Ngāti Kahungunu exhibitions and taonga case study projects examined in Chapters Three and Four, Te Hau ki Türanga offers an opportunity to assess the significance of a tribal taonga that was confiscated by the Crown in 1867. The Te Hau ki Türanga wharenui of Rongowhakaata has been selected as a case study because it is a contemporary example of a tribal taonga that is important to the Rongowhakaata people of Turanganui-a-Kiwa (Gisborne), both in historic and contemporary times. Te Hau ki Türanga

86 McCarthy, 2007, 22. The changing contexts of Te Hau ki Türanga are described by McCarthy as a symbol of chiefly mana, a trophy, a curio, a specimen, an artefact, a model of arts and crafts, a national treasure, a masterpiece of primitive art and taonga (cultural treasure) (p.199). 
has been the subject of a recent Treaty of Waitangi claim that was settled in September 2011, although the journey of Te Hau ki Türanga will continue through to 2017, the date given for its return to Gisborne.

Although the history of Te Hau ki Türanga is well documented in the Waitangi Tribunal (Wai 814) Report, some of the more salient points of Te Hau ki Türanga's history are outlined to provide an historical context on which to assess the relationship of this taonga with its Rongowhakaata people with respect to Rongowhakaata tribal identity and development.

\section{History}

Te Hau ki Türanga has been translated as the 'spirit' or 'good tidings' from Turanga, as well as the breath and vitality of Turanga. ${ }^{87}$ Te Hau ki Türanga was carved by the master carver, Raharuhi Rukupo, in the early 1840s with 18 carvers from Turanga. ${ }^{88}$ Rukupo's reputation as a master carver is well established in New Zealand's art history and his masterpiece Te Hau ki Türanga is often associated with Rukupo's carving style or what is also described as the 'Turanga' carving style. ${ }^{89}$ The wharenui was believed to have been built as a memorial to Tamati Waka Mangere, ${ }^{90}$ elder brother of Raharuhi Rukupo, who signed the Treaty of Waitangi in 1840. In 1867 the Crown confiscated the wharenui. The Crown assumed possession and ownership of Te Hau ki Türanga in March 1867 after the hostilities of Waerenga-ā-hika in 1865. ${ }^{91}$ J.C. Richmond sought to acquire the meeting house when he visited Turanga as part of the Crown's policy of land confiscation from the tribes deemed disloyal.

J.C. Richmond was responsible for Te Hau ki Türanga being taken from its tūrangawaewae or home landscape inside the Orakaiāpu pā, Manutūke. Richmond was a Government

87 Waitangi Tribunal. 2004. 'Turanga Tangata, Turanga Whenua: The Report on the Tūranganui-a-Kiwa Claims' (Wai 814) for Te Hau ki Tūranga (Chapter 10) p.589.

88 The carvers were Enoka, Hakaraia Ngapatari, Hamiora Te Uarua, Heta Meha, Himiona Te Papaapiti, Hirawanu Tukuamiomio, Hone Tiatia, Hopa, Reweti Tauri Tuhura, Mahumahu, Matenga Tamaioria, Matenga Te Hore, Natana Hira Toromata, Paora Rakaiora, Pera Tawhiti (Rukupo's younger brother), Poparae Kemaka, Rawiri Hokeke and Wereta Whakahira. (See Brown, Deidre. 1996. "Te Hau ki Tūranga." The Journal of the Polynesian Society no. 105 (1):7-26.).

89 Brown (1996) says that Rukupo trained in the pre-Pākehā system of carving, but readily adopted new ideas from other tribes, including religions and cultures. An example of this is the literal identification of ancestors around the house. The Turanga carving style is often recognized as one of the highest expressions of carving excellence.

90 Tamati Waka Mangere signed the Treaty of Waitangi in 1840 (Brown, 1996, 10).

91 "Reasserting mana and a major 'new' attraction." 2011. Gisborne Herald, 27 June 2011, 14. 
Minister who also acted informally as the Director of the Colonial Museum. ${ }^{92}$ On

Richmond's instructions, Te Hau ki Türanga was loaded on board the government steamer

Sturt by Captain Fairchild and taken to the Colonial Museum in Wellington. The Turanga people clearly did not agree and support the taking of their wharenui and this is borne out in Fairchild's evidence before the Native Affairs Select Committee in October 1878:

The Hon J C Richmond sent me for the House. He came to Turanganui, and told me to go back and get the house ... We took the house down; the natives objecting all the time. They objected as I took stick after stick ... The natives objected to my taking the house after the money was paid ... I had to take the house by force. I own to that. They stood there, and objected to every stick that was touched ... I was taking it down against their will. I took it with the tomahawk against their will ... They came with a bullock team to remove the balance of the house away. I was afraid they would get it away into the bush, and so I watched what remained of it all night long. ${ }^{93}$

Following the confiscation of Te Hau ki Türanga there were continuous requests and petitions by Rongowhakaata leaders to have the meeting house returned. Since 1867 there have been two petitions that have called for the return of Te Hau ki Türanga, notwithstanding the Rongowhakaata Waitangi Tribunal claim that commenced in the 1990s. The first petition in relation to Te Hau ki Türanga was sent by Raharuhi Rukupo, the master carver of Te Hau ki Türanga, and seven others in July 1867, who had objected to the house being taken. ${ }^{94}$

As noted in the Waitangi Tribunal Report concerning Te Hau ki Türanga, J.C. Richmond sent Captain Fairchild to collect the whare and that, "Fairchild removed the whare by force, despite the protests of many Māori." 95 The response to Rukupo's petition was that the Select Committee agreed with Richmond's statement. The Waitangi Tribunal report noted that "the building appeared to be deteriorating, a considerable amount of money had been paid for it, and, because the owners of the land and the whare were 'rebels', the whare had 'strictly speaking' been 'forfeited to the Government'." 96 The taking of Te Hau ki Türanga was again revisited when G.W. Rusden published his book History of New Zealand in 1883 where he included some lines of Richmond's confiscation of Te Hau ki Türanga. ${ }^{97}$

92 Waitangi Tribunal, 2004, p.590.

93 See Waitangi Tribunal, 2004.

94 Ibid, 587,591-2. Rukupo also said to Richmond that it was not his decision alone.

95 Ibid.

96 Ibid, 587-588. The resident magistrate Biggs paid $£ 100$ to certain Māori.

97 See Rongowhakaata website. During this time the Daily Southern Cross newspaper also made mention of the house being removed 'without the owners being consulted on the subject any more than that one old man was pressed into giving his unwilling consent' (Waitangi Tribunal Report (Wai 814) 2004. p.591) 
A second petition calling for the return of Te Hau ki Türanga soon followed and was initiated by Wi Pere, Keita Wyllie and Otene Pitau in October $1878 .{ }^{98}$ The result of this petition was that a further $£ 300$ was recommended to pay to the tribal owners as the original $£ 100$ was seen as inadequate. ${ }^{99}$ From 1868 through to the 1920s, Te Hau ki Türanga went on display at the Colonial Museum (later the Dominion Museum). McCarthy notes that Te Hau ki Türanga's acquisition was at the time of the military conflict between the 'rebel' Māori and government forces backed by loyalist Māori and that it was then displayed in the capital as a 'trophy of colonial conquest'. 100

The Dominion Museum was then situated near Parliament buildings in Museum Street and it was here that Ngata and the carvers from the School of Arts and Crafts undertook the carving restoration for Te Hau ki Türanga. ${ }^{101}$ The wharenui was substantially renovated in the 1920s and '30s through the leadership of Apirana Ngata and the School of Māori Arts and Crafts. Major architectural changes were made to Te Hau ki Türanga at this time with little involvement with Rongowhakaata. ${ }^{102}$

Ngata used Te Hau ki Tūranga as his prototype model of a meeting house for his Māori renaissance. Unfortunately, the original structural dimensions of the porch were dramatically changed to adhere to aesthetic and visitor appreciation, notwithstanding the different styles employed in the carvings that replaced those that were missing. ${ }^{103}$ Deidre Brown describes the changes to Te Hau ki Türanga as a contextual change from turangawaewae to classification where museums were being classified into categories and hierarchies within the popularity of social-Darwinism. In this scenario western knowledge dominates and colonization is appreciated as a form of 'civilisation' ${ }^{104}$ This treatment of recontextualization is further described by McCarthy as 'from taonga to curio, ${ }^{105}$ and is similar to that experienced by Ngāti Awa with regard to their Mataatua wharenui.

98 See Waitangi Tribunal,2004 (p.593-595).

99 Ibid. 588. This money was paid in 1880.

100 McCarthy, 2007, 22.

101 McCarthy, 2011, 35.

102 Brown (1996) reminds us that Te Hau ki Türanga became Ngata's model for the re-invention of the Māori meeting house and Māori renaissance (p.17-22). See also Skinner, Damian. 2008. The Carver and the Artist: Māori Art in the Twentieth Century. Auckland Auckland University Press.

103 See Brown, Deidre. 1996. "Te Hau ki Tūranga." Journal of the Polynesian Society no. 105 (1):7-26.

104 Ibid. 4. Brown notes that the restoration of Te Hau ki Türanga by Apirana Ngata demonstrates 'the subjective uses of western scientific knowledge' and that by classifying Rukupo's work as 'style' or 'tradition' rather than spoils of confiscation or a product of a whare wānanga, he was able to reconcile Māori culture with Pākehā colonisation (p.8).

105 See McCarthy, 2004. 
Te Hau ki Türanga opened at the new Dominion Museum in Buckle Street in 1936. What seems certain is that Rongowhakaata had very little involvement in the renovation of Te Hau ki Türanga at this time and this continued largely through to the 1980s. ${ }^{106}$ In the late 1980s a new relationship was established between Rongowhakaata and the National Museum that focused largely on the building of the new National Museum on Wellington's waterfront and the positioning of Te Hau ki Türanga within it. As part of this emerging new relationship, the $150^{\text {th }}$ celebration of Te Hau ki Türanga was held on $20^{\text {th }}$ October to $1^{\text {st }}$ November 1992 at the old museum in Buckle Street. For many Rongowhakaata descendants, it was the first time that they had slept inside their ancestral wharenui and much debate and discussion was held. As part of this new relationship, Te Papa returned painted kōwhaiwhai panels associated with the early Manutūke Anglican church to Rongowhakaata in 1994 as a 'partnership agreement' with the tribe. ${ }^{107}$

\section{Rongowhakaata Waitangi Tribunal claim}

A great injustice was perpetrated on the Rongowhakaata people in the 1860s with the taking of lives, land and valuable taonga, such as Te Hau ki Türanga. The Waitangi Tribunal report on Te Hau ki Türanga was forthright in its determination when it stated that "It is our finding that the acquisition of Te Hau ki Türanga by the Crown in 1867 was in breach of article 2 rights of Rongowhakaata to the exclusive and undisturbed possession of their property and other taonga." 108 This injustice was reiterated by the Minister of Treaty Settlements, Hon. Christopher Findlayson, at the initialling of the Rongowhakaata Deed of Settlement for the Tūranganui-a-Kiwa Waitangi Tribunal claim held at Te Papa on $20^{\text {th }}$ July 2011: “This settlement puts right a great wrong that has been done to Rongowhakaata, the creators and rightful owners of such a beautiful and important taonga." 109

The Rongowhakaata Waitangi Tribunal claim for Te Hau ki Tūranga arguably started in 1867 when Raharuhi Rukupo and other Turanga chiefs petitioned against the taking of the whare whakairo. The Waitangi Tribunal claim has been the focus of the Rongowhakaata Charitable

\footnotetext{
106 Rongowhakaata Halbert provided whakapapa of the tipuna represented in the whare to the museum ethnologist W.J. Phillips in the 1950s to "60s. See the evidence of Lewis Moeau in the Waitangi Tribunal Report "Turanga Tangata, Turanga Whenua: The Report on the Turanganui a Kiwa Claims Volume II." Wellington, 2004, pp.603-4.

107 Waitangi Tribunal 2004.

108 Ibid. 598.

109 Finlayson, C. 2011. "Deed of Settlement signed with Rongowhakaata." Retrieved 30th September, from http://www.beehive.govt.nz/release/deed-settlement-signed-rongowhakaata.
} 
Trust since 1998 when it was first established. ${ }^{110}$ Stan Pardoe says that the kaumātua of Rongowhakaata played a central role in the development of the claim and evidence ${ }^{111}$ and that meetings were held on all the Rongowhakaata marae, including Pahou, Whakatō, Manutūke, Ohako and Te Kura-a-Tuatai. ${ }^{112}$

The Waitangi Tribunal report on the Tūranganui-a-Kiwa claim was formally handed to claimants at the Whakatō marae on $30^{\text {th }}$ October 2004. However, for Te Hau ki Türanga, resolution began earlier in September 2001 when the Crown told the Waitangi Tribunal and Rongowhakaata that it considered the removal of Te Hau ki Türanga was without proper consent and was a breach of the principles of the Treaty of Waitangi. ${ }^{113}$ The Deed of Settlement was signed at the Whakatō marae, Manutūke on $30^{\text {th }}$ September 2011.

How Rongowhakaata taonga like Te Hau ki Türanga are viewed by their kin can be clearly seen in how Rongowhakaata communicate the significance of Te Hau ki Türanga. Te Hau ki Türanga is on their tribal website, in their tribal newsletters, and more recently in a haka performed by the Rongowhakaata Māori Cultural Group 'Tu Te Manawa Maurea' at the Te Matatini Māori Performing Arts Competition at Waihirere, Gisborne in $2011 .^{114}$

The words of the haka express the deep sadness of the confiscation of Te Hau ki Türanga and it is pivotal for the tribe. The taking of the wharenui was likened to ripping out the heart and severing the umbilical cord of Te Hau ki Türanga and its Rongowhakaata people. The words of the haka speak about the people standing naked, a 'stranger' to their ancestral meeting house for over 140 years. The anguish and pain suffered as a result of the confiscation is included in the haka, as is the hope and aspiration that Te Hau ki Türanga to call Rongowhakaata to come together again to "build our people and re-establish the link between people, house and our ancestors Rukupō."115 The words say that the wharenui has been a stranger from its people for too long and that we want to fix the house and ourselves.

\footnotetext{
110 The Charitable Trust was first established in1998. Rongowhakaata interests were taken care of before 1986 through the Te Rūnanga o Tūranganui-ā-Kiwa, but the tribal entities felt that they needed to create their own governance structures to advance their interests.

111 Brief of Evidence of Stanley Joseph Pardoe for Rongowhakaata Wai 684.

112 Ibid. Pardoe reminds us that there are six Rongowhakaata marae, including Te Hau ki Türanga held at Te Papa.

113 See "Reasserting mana and a major 'new' attraction." 2011. Gisborne Herald, 27 June 2011, 14.

114 The Tu Te Manawa Maurea Māori Cultural group was formed in the mid-2000s.

115 In the explanations of the haka 'Te Hau ki Türanga' by the Rongowhakaata Cultural Group 'Tu Te Manawa Maurea.' The words were kindly given by David Jones.
} 


\section{Tu Te Manawa Maurea Haka 'Te Hau ki Tūranga'}

\begin{tabular}{|c|c|}
\hline $\begin{array}{l}\text { Kua horapa kē ia te rongo ki ngā iwi o te motu mō } \\
\text { te tohunga whakairo, te kātuarehe, Rukupō. }\end{array}$ & $\begin{array}{l}\text { The prestige of Rukupō as a master carver has been } \\
\text { heard and spoken of across the country. }\end{array}$ \\
\hline $\begin{array}{l}\text { He toki, He toki } \\
\text { He toki Rangiāhua } \\
\text { Nā Kaipoho koā } \\
\text { Nō Hāmokorau. }\end{array}$ & $\begin{array}{l}\text { He is a master } \\
\text { Skilled craftsman } \\
\text { He is of Kaipoho } \\
\text { From the school of Hāmokorau. }\end{array}$ \\
\hline $\begin{array}{l}\text { Raharuhi Rukupō } \\
\text { He mana whakairo } \\
\text { He mana motuhake } \\
\text { He mana tiketike. }\end{array}$ & $\begin{array}{l}\text { Raharuhi Rukupō } \\
\text { A master carver } \\
\text { A distinctive and autonomous authority } \\
\text { Who excelled the artform. }\end{array}$ \\
\hline $\begin{array}{l}\text { Ka tuhi toki ka uira! Ko wai te whare nei? } \\
\text { Ko Te Hau ki Tūranga. } \\
\text { Ko Te Hau ki Tūranga. } \\
\text { Ko taku tīpare whakarei, taku Manawa, manapou o } \\
\text { te iwi ka ngangare nei. }\end{array}$ & $\begin{array}{l}\text { When his adze struck, his work gleamed/flashed. } \\
\text { What is this house? It is Te Hau ki Tūranga. Te Hau } \\
\text { ki Türanga. } \\
\text { It is my identity, my heart, the essence of my people } \\
\text { and I have a quarrel. }\end{array}$ \\
\hline $\begin{array}{l}\text { Rukupō, Ka ngangare nei } \\
\text { Ngāti Kaipoho, Ka ngangare nei } \\
\text { Rongowhakaata, Ka ngangare nei } \\
\text { Aue! Kia kite mai koe } \\
\text { Ngā riwha kei toku poho } \\
\text { Kia kite mai koe } \\
\text { Te mamae e kaikini kino tonu nei } \\
\text { Aue taukuri hei! }\end{array}$ & $\begin{array}{l}\text { Rukupō quarreled } \\
\text { We as Ngāti Kaipoho have a quarrel } \\
\text { We as Rongowhakaata people have a significant } \\
\text { quarrel } \\
\text { Alas! May you see } \\
\text { The scars that adorn our people } \\
\text { May you see } \\
\text { The pain that still shreds away at us as a people } \\
\text { And this distresses me! }\end{array}$ \\
\hline $\begin{array}{l}\text { E ngaki ana ā mua, e toto ana ā muri } \\
\text { I ū mai Ngā Mihinare } \\
\text { I ù mai Ko ngā Hōia muruwhenua } \\
\text { I ù mai Ko te iwi whānako e }\end{array}$ & $\begin{array}{l}\text { Clear a path in front, so that you may lay a new crop } \\
\text { - the missionaries descended and cleared a path for } \\
\text { the soldiers who came and took the land who cleared } \\
\text { the path for those who stole what was ours. }\end{array}$ \\
\hline $\begin{array}{l}\text { Ūpokohua! } \\
\text { Te karauna minamina, pukurua, puruheti e! } \\
\text { Tōku tīpuna whare } \\
\text { I tāhae, i kahakina } \\
\text { Taku Manawa } \\
\text { I tīkarohia! Ko te iwi tū kirikau aue taukuri hei! }\end{array}$ & $\begin{array}{l}\text { F\#king bastards! } \\
\text { It was the hungry, gluttonous and bullshitting } \\
\text { Crown. It was my house } \\
\text { That was stolen and taken. By doing so my heart that } \\
\text { was ripped apart! And here I stand naked with } \\
\text { nothing and this distresses me so! }\end{array}$ \\
\hline $\begin{array}{l}\text { Kore kē i ārikarika, te ngare à te iwi ki ngā } \\
\text { whakaparahakohako }\end{array}$ & $\begin{array}{l}\text { The fighting and quarrelling of our people continues } \\
\text { in the face of the condescending and patronizing } \\
\text { decisions around our house }\end{array}$ \\
\hline $\begin{array}{l}\text { Tuatahi } \\
\text { Pōpōroa kē e noho manene ana }\end{array}$ & $\begin{array}{l}\text { One } \\
\text { It has been a stranger from its people for far too long }\end{array}$ \\
\hline $\begin{array}{l}\text { Tuarua } \\
\text { I tapahia ngā pou! Kōraparapa kē te noho o ngā } \\
\text { tipuna }\end{array}$ & $\begin{array}{l}\text { Two } \\
\text { The bottoms of the carvings were cut! Our ancestors } \\
\text { now stand out of place in their house }\end{array}$ \\
\hline
\end{tabular}




\begin{tabular}{|l|l|}
\hline Tuatoru & $\begin{array}{l}\text { Three } \\
\text { Ko nga pou whakairo taketake kua marara ki roto o } \\
\text { iwi kē! Tenā kai a te ahi! Taurekareka ! } \\
\text { E Te Papa Tongarewa, kua whati kē te raro } \\
\text { Māku ake tōku whare hei whakatika carvings of the house are } \\
\text { scattered around the world! This angers me! } \\
\text { Te Papa Tongarewa, The time has come. } \\
\text { Let us as a people fix our house and ourselves }\end{array}$ \\
\hline $\begin{array}{l}\text { Rongowhakaata } \\
\text { Kēnā rukuhia whiwhia, ruku rawea, rukupō! } \\
\text { I au, au aue hā hi ! }\end{array}$ & $\begin{array}{l}\text { Rongowhakaata people } \\
\text { The time has come } \\
\text { Let us go back to wananga, to talk and delve deeply } \\
\text { and sort ourselves out, diving into the depths of the } \\
\text { night... to satisfy those longings of our ancestor } \\
\text { Rukupō. }\end{array}$ \\
\hline
\end{tabular}

Te Hau ki Türanga's mana is not confined to a distant past unconnected with its people and history. The ancestors continue to be relevant in the present and future and there are strong calls for Te Hau ki Türanga to be the focus for Rongowhakaata cultural renewal and revitalization. The words describe the relationship of Te Hau ki Türanga and its Rongowhakaata people - 'Ko taku tīpare whakarei, taku Manawa, manapou o te iwi' (It is my identity, my heart, the essence of my people). There is also a plea in the words of the haka for the people to fix the house and themselves with the words "Māku ake whare hei whakatika."

In a similar fashion to Te Aitanga-a-Hauiti, Rongowhakaata signals a desire to go back to wānanga to reclaim and re-energise the histories and cultural strengths. The haka calls for Rongowhakaata to go back to wānanga to help them and to satisfy the longings of the master carver of Te Hau ki Türanga, Raharuhi Rukupo. ${ }^{116}$

Te Hau ki Türanga tells the stories of 'real' relationships to past events and aligns strongly with Pearce's views when she says: “Objects, we have noted, have lives, though finite, can be very much longer than our own. They alone have the power, in some sense, to carry the past into the present by virtue of their "real' relationship to past events." ${ }^{117}$ Seen in another way, Te Hau ki Türanga has become the taonga on which Rongowhakaata can restore and revitalize them for a better future. The loss of lives, land and great artistic traditions, including the Turanga or Rukupo carving style and the distinctive kōwhaiwhai painting art form, was devastating to Rongowhakaata.

\footnotetext{
${ }^{116}$ In the explanation of the haka it says that Tu Te Manawa Maurea has adopted the statement 'He reo pakura ki te po' as one of their main themes for their performing bracket. Contained in this are statements about who Rongowhakaata are, what they are as a people and the aspiration to live together and work together, and wānanga.

117 Pearce, 1992, 24.
} 
For the Rongowhakaata tribal member, Jody Wyllie, Rongowhakaata have been dispossessed of the Turanga carving style and Te Hau ki Türanga is the greatest symbol of their style and renaissance package. ${ }^{118}$ It is hoped that the return of Te Hau ki Türanga will help reclaim and restore the rich carving tradition associated with Raharuhi Rukupo and assist with the cultural revitalization of Rongowhakaata tribal identity. The importance of the reclamation and revitalization of the Rukupo carving art form, for example, is one of those wānanga dimensions and within the haka described Rukupo as, "He mana whakairo, He mana motuhake, He mana tiketike - A master carver, a distinctive and autonomous authority, who excelled the artform."

The return of Te Hau ki Türanga is an important dimension of restorative justice, healing and reconciliation for Rongowhakaata. The six R's that Rongowhakaata negotiators discussed in the early planning stages of their Waitangi Tribunal claim and presented by Rongowhakaata representatives at a hui at Te Papa on $22^{\text {nd }}$ April 2010 align strongly with Simpson's perspectives on the link between heritage, health and wellbeing and the recognition of the contemporary value of heritage for living cultures. ${ }^{119}$ The six R's discussed by Rongowhakaata negotiators were:

Relate - the story of the whare and Raharuhi Rukupo.

Repatriation - the whare and all of its treasures according to tikanga.

Restore - the mauri mana motuhake of the whare according to tikanga.

Return - Te Hau ki Tūranga to Manutūke when Rongowhakaata are ready.

Review - the goals and progress to ensure the best interests of the taonga and the people according to our tikanga.

Relationships - the kaupapa must respect the mana of all who are a part of the Te Hau ki Türanga mamae. Moreover Rongowhakaata will need the awhi and aroha of many, over time. ${ }^{120}$

118 Jody Wyllie made this comment at a joint meeting of the Rongowhakaata Iwi Trust, the Te Hau ki Türanga Trust and Te Papa at a meeting held at Te Papa on $16^{\text {th }}$ April 2013.

119 See Simpson, 2009, 122.

${ }^{120}$ Closely associated with these six R's was the desire to acknowledge the mana rangātira of Raharuhi Rukupo and the Rongowhakaata carving style and the revitalization of the people. 
The proposed repatriation of Te Hau ki Türanga is in one sense a strong dimension of healing, reconciliation and restorative justice ${ }^{121}$ and in another of regenerating identity. Hill reminds us that repatriation is not the end, but rather a new beginning and a regeneration of identity:

Repatriation is not an end; it is, in many ways, a new beginning. Through the processes and relations it engenders, museums will come to understand that cultural preservation is not only about keeping objects from decaying but also about keeping ideas, values, and beliefs viable for the many generations to come. ${ }^{122}$

As reported in the Gisborne Herald, Te Hau ki Türanga has become a symbol of renaissance, inspiration and leadership: ${ }^{123}$

This redress of a confiscation by force over 140 years ago will close a chapter on our colonial past and reassert the mana of the Manutūke area iwi, which led the country in traditional arts. Te Hau ki Türanga, their wharenui, embodies that leadership. Its return will be inspiration for the many talented Rongowhakaata artists reclaiming the mantle, and no doubt will also calm the ancestors who built it and the many who petitioned for its return over the years. ${ }^{124}$

McCarthy's statement in his publication Museums and Māori: Heritage Professionals, Indigenous Collections, Current Practice that Te Hau ki Türanga could become the seedbed of Rongowhakaata cultural regeneration takes on new meaning as this is exactly how this taonga is positioned by the tribe. ${ }^{125}$ For Jody Wyllie, Te Hau ki Türanga should be remembered because it is an important part of Rongowhakaata's whakapapa and as a premier taonga it is also an important part of the tribe's re-education and healing process. ${ }^{126}$ As

Wyllie says: "One of the problems that we have is a lot of our people don't know about this. This is a very important mnemonic device that will help generations to remember." ${ }^{127}$ Wyllie is in no doubt aware of the cultural implications for the return of Te Hau ki Türanga and the opportunities it will create for cultural tourism, the arts and education.

There are a number of opportunities to develop Rongowhakaatatanga through this house, but with each opportunity comes issues to consider. Opportunities include cultural development

\footnotetext{
121 After Simpson, 2009.

122 See Hill, 2007.

${ }^{123}$ See "Reasserting mana and a major 'new' attraction." 2011. Gisborne Herald, 27 June 2011, 14.

${ }^{124}$ Ibid.

125 McCarthy, 2011, 218.

126 See Torrie, Bronwyn. 2011. 'Te Papa to lose treasured Māori whare'. The Dominion Post. Wellington: 2. See also McCarthy, 2011 where Wyllie is credited with saying that 'If you want to give life to a particular carving, it would best to come from the people who created it' (p.218).

127 Ibid.
} 
in areas of education, iwi development, traditional arts and crafts, performing arts, tourism, environmental conservation and others. Cultural development needs to be looked at strategically as part of the future vision for Te Hau ki Türanga and the broader vision for Rongowhakaata iwi. ${ }^{128}$

Like Te Aitanga-a-Hauiti and the traditions and knowledge of the Te Rāwheoro Whare Wānanga, Jody Wyllie emphasizes the wānanga dimension and the potential of Te Hau ki Türanga to be a 'cultural beacon' for Rongowhakaata's future. Wyllie also poignantly says that Te Hau ki Türanga as a cultural beacon can be the taonga on which future generations can measure their Rongowhakaatatanga:

Te Hau ki Tūranga holds centrepiece out of all our Taonga that we have as a people; this is probably the premier example that we have as a people. The important thing for me that I have come to realise over the last few years about our whare is that it is a wananga particularly around carving that our ancestors have left behind... It really should be put back onto the land in which it was taken so that it can be used as a what I call a cultural beacon for future generations. A way in which future generations can measure their Rongowhakaatatanga ah moving forward into the future... This Settlement will not be complete until our whare is relocated back to Turanga. It is not appropriate and it is a very simple equation that the Crown came here in 1867 stole our house and want to leave it in Wellington... But what we do know is this that we have a very unique opportunity from all the examples of taonga that they have left behind including Te Hau ki Tūranga to examine the past so that we can move forward into the future. ${ }^{129}$

\section{Ngāti Awa - Mataatua wharenui}

\section{Bindings that cannot be loosened by the sun or softened by the rain}

Mataatua is a carved meeting house that belongs to the Ngāti Awa tribe of the Eastern Bay of Plenty. Mataatua was carved in 1873-75, but within a short period of time was dismantled and taken overseas where it was included in colonial and empire exhibitions. In 1924

Mataatua returned to New Zealand where it was included in the New Zealand South Seas Exhibition in Dunedin and from there it became included in the Otago Museum exhibits. The

\footnotetext{
128 See Wyllie, Jody. 2009. Te Hau ki Türanga Integrity Audit/Ownership Issues Report, Crown Forest Rentals Trust p.30.

129 Interview with Jody Wyllie, $29^{\text {th }}$ September 2011.
} 
journey of Mataatua did not include its owners Ngāti Awa, but rather took it away from its people and ancestral home. Mataatua's story is a tragic and sad one as its journey to return home has been long, hard and arduous. ${ }^{130}$

With regard to Mataatua's journey, Sid Mead says: "Within Mataatua is a gallery of ancestors who were rudely taken from home and cast adrift for over a century before a call was made for them to come home."131 Mead described the Mataatua wharenui in 1990 as the wandering ancestors and the structure that binds them together that one day will stand again at Whakatāne. ${ }^{132}$ How prophetic his words were. In the research report on Mataatua it says that the Mataatua whare was written with a plea that one day their (i.e. Ngāti Awa's) grievances might be addressed, their pains healed, and Mataatua will stand again in Whakatāne. ${ }^{133}$ For Mead, Ngāti Awa's rangatiratanga was compromised, but the story of its history was one worth telling. ${ }^{134}$

Kylie Message speaks about the metaphor of 'survivance' and how this term means doing whatever is necessary and that survivance is more than survival. Survivance means redefining ourselves and raising our social and political consciousness. It means holding onto ancient principles while eagerly embracing change. It means doing what is necessary to keep cultures alive. ${ }^{135}$ Ngāti Awa's experience is akin to the survivance metaphor as noted by Message. In the face of continued opposition, they have remained resolute and campaigned vigorously and continuously for their wharenui to be returned. They have embraced change yet held on to ancient principles that express their Ngāti Awatanga.

The frustration of inactivity was evident when Sid Mead wrote in 1995 that "the patience of Ngāti Awa has run out and that a Raupatu Committee of Ngāti Awa has been formed to direct the claim against the Crown." ${ }^{136}$ Mataatua's tragic history is like that of Te Hau ki Türanga of Rongowhakaata where an important tribal taonga was taken away from its cultural owners over 100 years ago.

${ }^{130}$ These words were expressed by Sir Sid Mead to members of the Te Hau ki Türanga Trust of Rongowhakaata when they visited Mataatua on $21^{\text {st }}$ March 2013. Other members of Ngāti Awa who were part of the panel discussion included Hawiki Ranapia (project manager), Pouroto Ngaropo (trustee) and Layne Harvey (legal advisor).

${ }^{131}$ Mead, Hirini Moko. "Nga Karoretanga O Mataatua Whare: The Wanderings of the Carved House Mataatua.” In Research Report no.2. Whakatane: Te Rūnanga o Ngāti Awa, 1990. p. 10.

132 Ibid. 11.

133 Ibid. 10.

${ }^{134}$ Ibid.

${ }_{135}$ Message, 2006, 1.

${ }^{136}$ Mead, 1995, 75. Mead noted that the only way to move forward was to charge the government with conversion of a cultural property. 


\section{Trying to rebuild Humpty Dumpty!}

The process to find and return lost treasures scattered to the four winds is a burgeoning activity for many First Nation and indigenous peoples. The reassembling of important tribal taonga held in museums is an important initiative of indigenous cultures and, as Mead reminds us: "for some indigenous peoples who have lost most of their culture, the process is like trying to rebuild Humpty Dumpty." 137 The process of colonization has impacted heavily on Māori and indigenous peoples. An example of the colonizing influence of museums is seen with the collecting of artefacts and the subsequent reappropriation and decontextualization of them within alien and western museum contexts. Collecting was a familiar activity in the colonial era, along with the commodification and appropriation of indigenous knowledge systems. Collectors and their collections were classified according to their western discipline areas of interest.

\section{History}

The full history of the Mataatua meeting house has been detailed in at least four major publications, notwithstanding the Ngāti Awa Waitangi Tribunal claim ${ }^{138}$ that was settled in 2005. What we know is that the Ngāti Awa carved wharenui Mataatua was built in 18731875 and opened in Whakatāne in March 1875 around 10 years after Ngāti Awa suffered military invasion and raupatu. ${ }^{139}$ The reason for the building of Mataatua was to celebrate the ancestors of Ngāti Awa and its allies, ${ }^{140}$ although other reasons have been given, including the need to replace the whare that had been destroyed by fire and to commemorate the destroyed sacred tree Te Puhi o Mataatua. ${ }^{141}$

The designer, architect and master carver of Mataatua was Wepiha Apanui of Ngāti Awa. The other carvers were from several tribes, including Te Whakatohea, Te Whānau-a-Apanui, Ngāi Tūhoe (Urewera) and Ngāti Awa. ${ }^{142}$ The opening of Mataatua was recorded in the Bay

\footnotetext{
137 Mead, 1995, 71.

138 See Mead, H. M. 1990. "Nga Karoretanga o Mataatua Whare: The Wanderings of the Carved House Mataatua". Research Report no.2. Whakatane, Te Rūnanga o Ngāti Awa; Woods, T. 1989. Te Ripoata a te Tari Māori e pa ana ki te tono a Ngāti Awa mo tona whare mo Mataatua. Department of Māori Affairs; Mane-Wheoki, J. (1993). Mataatua: No wai tenei whare tupuna? A Report on the Ngāti Awa Claim (Wai 46) Commissioned by the Waitangi Tribunal, Waitangi Tribunal; Phillips, W.J., and J.C. Wadmore. 1956. The Great Carved House Mataatua of Whakatane. Wellington: Valley Printing Company, Petone.

139 Ibid, 12.

${ }^{140}$ Ibid, 13.

141 Mane-Wheoki, 1993, 12.

${ }^{142}$ Mead, 1990, 15. The carvers included Mohetei (Te Urewera), Tiopira and Tutere (Rangitaiki), Te Wikirihotu (Patuwai), Tikitiki (Te Whakatohea) and Paniora (Te Whanau-a-Apanui).
} 
of Plenty Times on $13^{\text {th }}$ March 1875 and included a programme planned for three days. A large number of natives, prominent chiefs and tribes were present with Sir Donald McLean attending. ${ }^{143}$

In 1879, Mataatua was dismantled and shipped overseas to be exhibited in overseas empire exhibitions. Much discussion and correspondence took place at this time and Mead records that there was division among the people about Mataatua leaving. ${ }^{144}$ Mataatua was erected as part of the Inter-Colonial Exhibition, Sydney in 1879-1880, and after this the International Exhibition, Melbourne in 1880-81. It was the first major Māori exhibition held in Sydney, but its presence there graphically illustrated the reappropriation from taonga to ethnological curiosity. In a public display of cultural arrogance and insensitivity, Mataatua was literally turned inside out with the poupou and tukutuku panels facing outwards. Mead notes that such a violation of the integrity of Māori culture was common at that time. ${ }^{145}$ This assimilation into the British Empire Exhibition changed Mataatua from being a 'living' meeting house, as noted by Mead, to that which had become an ethnological curiosity. ${ }^{146}$

After Melbourne, Mataatua then travelled to London where it was erected and stored at the South Kensington Museum in 1882-1922. The house was only erected for four years at the South Kensington Museum when it was taken down and stored due to other building purposes. ${ }^{147}$ Following this, Mataatua went to the British Empire Exhibition, Wembley in 1924 where King George and Queen Mary visited, along with the Prince of Wales. ${ }^{148}$ From there it travelled to the New Zealand South Seas Exhibition in Dunedin in 1925 where it was supported by the New Zealand Government. Following Mataatua's display at this exhibition, it was then given to the Otago Museum on long-term loan. The main parties responsible for

\footnotetext{
143 Ibid. 41.

144 Ibid. 66. Phillips and Wadmore $(1956,4)$ note that there was some dissatisfaction for Mataatua leaving and that some women encouraged the men to prevent the gift by stealing and concealing the tahuhu.

145 Mead, 1990, 72.

146 Mead further stated that the house had become alienated from the people who built it and used it and that it had become culturally dislocated (p.72). McCarthy notes that the only concession to this bizarre sight was the history of Mataatua recounted by the carver Wepiha Apanui that was placed in the court (McCarthy, 2007, 37).

147 Ibid. 42.

148 Ibid. 84.
} 
this included the Under-Secretary for Internal Affairs (Mr J. Hislop), Curator of the Museum of the University of Otago (Professor W. Benham) and the Director of the Dominion Museum (Mr J. Allan). ${ }^{149}$

The next series of transactions regarding Mataatua occurred after the Ngāti Awa Trust Board was formed in 1980 where it showed a continuous record of requests to have Mataatua returned to its people. Commencing in 1983, Ngāti Awa met with Hon. Ben Couch, Minister of Māori Affairs, calling for the return of the whare and Sid Mead's requests to the Otago Museum to have the house returned. On $17^{\text {th }}$ March 1984 at a hui with the Ngāti Awa Trust Board at Taiwhakaea it was proposed that a cultural centre be built and Mataatua returned and incorporated within it. ${ }^{150}$

Linda Tuhiwai Smith in her seminal publication Decolonizing Methodologies: Research and Indigenous People writes that Mataatua was a specific example of "the colonization of an indigenous architectural space and of indigenous spatial concepts. ${ }^{, 151}$ Smith argues that Mataatua was "displayed 'inside-out' and lined with Chinese matting and that with its transformation and assimilation into a British Empire exhibition changed from being a 'living' meeting house, which the people used, and had become an ethnological curiosity for strange people to look at the wrong way and in the wrong place." ${ }^{\prime 52}$ In recognizing that collections and collecting was an integral part of colonialism, Smith also argues that colonialism involved rearrangement, representation and redistribution. ${ }^{153}$ The dislocation from their cultural foundations and how taonga have been incorporated into the 'cultural practices of the other colonizing cultures ${ }^{154}$ is commented on by Sid Mead with regard to the Mataatua meeting house:

Mataatua was defined as a valuable art object and kept in a museum with other similarly redefined objects from other cultures. Once locked in such an institution it becomes

\footnotetext{
149 Mane-Wheoki, 1993, 50. The correspondence suggests that Otago was offered the house because the Dominion Museum had Te Hau ki Türanga and the Otago Museum had no wharenui.

${ }^{150}$ Mead, 1990, 98.

151 Smith, 1999, 52.

152 See Smith, 1999, 52. (Original reference cited in Mead, H. M., 1990.).

153 Smith, 1999, 62. The example given by Linda Smith is Kew Gardens where the British Empire became the global laboratory for research.

154 Mead, H.M. 1995. "The Mataatua Declaration and the Case of the Carved Meeting House Mataatua." In Material Culture in Flux: Law and Policy of Repatriation of Cultural Property, edited by J. Wong et al.. Vancouver: University of British Columbia Faculty of Law, p.69-75.
} 
difficult for the owning culture to get it back. There have been many exceptions recently but this is no comfort to us. Mataatua remains locked up, imprisoned in a foreign land. ${ }^{155}$

The following response by Mead is important for my research dissertation as it follows on from the Crown's argument that Mataatua should remain as a museum artefact inside a building. Mead's comments reflect a larger viewpoint expressed by indigenous peoples and Māori that taonga have their 'right' context amidst their own people: ${ }^{156}$

The Ngāti Awa position is that "coming home" for Mataatua means an escape from the definitions of the museum world as well as from the walls of an institution. Mataatua is a wharenui, a whare rūnanga that is a big house, a meeting house. It was taken away as a functioning carved meeting house: it must return as such and not be classified as an ethnological curiosity to be imprisoned in a museum. Mataatua is a building, a carved meeting house and not an artifact to be locked away. ${ }^{157}$

The relationship between naming and power is highlighted by Ruth Phillips when she says that named categories that structure the museum are a residue of obsolete nineteenth-century ideologies: "they create domains of inclusion and exclusion that continue to inscribe colonial attitudes about race, patriarchal ideas about gender, and elitist notions about class."

During the time of the Te Mãori exhibition in the mid to late 1980s, Mead made the plea that Māori should take back and reclaim the language of definitions and let Māori speak for themselves, including about the interpretation of their taonga. ${ }^{159}$ What underlies Mead's comments is the conviction that museums should recognize Māori indigenous knowledge, values and beliefs. An important component of this is recognizing that taonga do have kōrero associated with them and that this korero provides meaning and connection to their descendant kin communities:

All objects that are called taonga have kōrero attached to them. The kōrero is a valuable aspect of any taonga and it is the kōrero that gives meaning and cultural significance to it. Kōrero enriches the taonga, enhances it, provides it with a history and links it very strongly to a particular social group such as a whānau, hapū or iwi who have cultural rights not only to the kōrero but also to the taonga itself. Providing kōrero is an expected part of the process of creating taonga. ${ }^{160}$

\footnotetext{
155 Ibid.

156 Monty Soutar expressed similar views with respect to Ngāti Porou taonga and that they could only 'live' if they were returned back to their people (Monty Soutar interview, $18^{\text {th }}$ August 2011).

157 Mead, 1990.

158 Phillips, 2011, 95.

159 See Mead, 1986. Ngahuia Te Awekotuku raised the issue of power, naming and provenance at the Museums Australia Conference in Australia 1996 with her address titled 'Who Called This a Club?'.

160 Mead, Sid, 1990 'The Nature of Taonga' in Taonga Māori Conference, New Zealand $18^{\text {th }}$ $27^{\text {th }}$ November 1990. Mark Lindsay (ed.). Wellington, Internal Affairs, pp.164-169.
} 


\section{Ngāti Awa Waitangi Tribunal claim}

Breathing life back into the taonga was something strongly argued by Mead in the Waitangi Tribunal Wai 262 Report along with the report recommendations that noted: "With respect to overseas institutions, we agree once more with Professor Mead and there can be little justification for the British Museum to hold in perpetual storage unique cultural artefacts that, if returned to New Zealand, would breathe life into dying or lost Māori arts - and which would themselves be revived by the presence of their kaitiaki." ${ }^{161}$ In 2002 Mead further argued that "Māori must drive this bus rather than be merely passengers" 162 with regard to their taonga and that significant research should be carried out on taonga to uncover the whakapapa and korero of each taonga ${ }^{163}$ and that iwi must play a greater role in relation to their taonga.

Particularly important for this thesis is that the feelings of Ngāti Awa regarding their ancestral meeting house were recorded in a paper that was sent to the Minister of Internal Affairs in 1984. Some of these are shown below, emphasizing the role and significance of the Mataatua wharenui to their Ngāti Awa tribal people:

The gift returns home to where it once stood and to its source.

The ancestors represented in the house are ancestors of the Mataatua tribes. They will be returning to the right environment, to their descendants and to their appropriate hapu

The house will act as a focus point for the tribe. It will lift the mana and self-esteem of all Ngāti Awa hapū.

It will become a rallying point for important tribal hui. It was a unifying house when it was opened in 1875 .

The talk surrounding this house will be revived and the history locked within it will be released. The house is like a comprehensive history book.

The heroes of Ngāti Awa and its founding ancestors are in this house. We refer to Tamatearehe, Awatope, Tuteao, Iratumoana, Te Ramaapakura, Te Rangikawehea, Te Rangihouhiri, Ikapuku, Umutahi and Te Maitaranui.

To the people of Ngāti Awa this house represents our past and contains within it a unique combination of our ancestors. There is no other house which has as much of our pain, frustration and disappointment built into its walls. Neither is there another house with so much of our pride and mana in it.

${ }^{161}$ See Mead, H. M. 2011. "Ko Aotearoa tēnei: A report into claims concerning New Zealand law and policy affecting Māori culture and identity”. Wellington, Waitangi Tribunal. Te Taumata Tuarua: Volume 2:510.

162 Ibid. 498.

163 See Mead, 2011, pp.497-498. Professor Sid Mead presented evidence on behalf of Ngāti Porou in 2002. 
The ancestors are meaningful to the people of Mataatua. They have no meaning for the people of Dunedin. ${ }^{164}$

Mataatua has often been described as a living being and even from those outside the tribe of Ngāti Awa, Mataatua has been seen as captive and imprisoned. Reaffirming the right of Ngāti Awa to decide its future is an important point made by Jonathan Mane-Wheoki in 1993:

From a Ngāti Awa point of view, however, Mataatua, as a living, organic being, is held captive in a tribally "foreign" territory, within an alien institutional cultural framework on what may be construed as an artificial life-support system... Were the whare to be released into the custody of Ngāti Awa, however, it would be entirely their prerogative, under tino Rangatiratanga, to determine Mataatua's future, and how they would utilize their whare tupuna.",165

Mataatua was an important pou of Ngāti Awa's Waitangi Tribunal claim and restorative justice and was completed when the house was eventually returned home to Ngāti Awa from the Otago Museum. Mataatua re-opened at Whakatāne on September $17^{\text {th }} 2011$ amidst joyous celebrations. The Mataatua wharenui has been described as an enduring symbol of Ngāti Awa persistence and determination ${ }^{166}$ and "the unifying soul of the Ngāti Awa tribe of Whakatāne, New Zealand."167

In 1990, Sid Mead wrote that the house began as a 'gift', believing the literature that it was gifted by the tribe, but the true facts concerning Mataatua came out later. ${ }^{168}$ Mead is very clear when he says that "Mataatua plainly belongs to Ngāti Awa and at no time was title to the house ever surrounded." 169 When asked 'What does coming home mean?' the response was:

Mataatua cannot come home as an artifact or as a display piece. It has to come home as "taonga tuku iho" and resume its special relationship with the people, a relationship that was interrupted for just over a century"... The Ngāti Awa position is that "coming home" for Mataatua means an escape from the definitions of the museum world as well as from the walls of an institution. Mataatua is a wharenui, a whare runanga, that is a big house, a meeting house. It was taken away as a functioning carved meeting house: it

\footnotetext{
164 See Mead, 1990, 98-99. On $15^{\text {th }}$ August 1984 the paper was compiled by Sid Mead and sent by the Ngāti Awa Trust Board to the Minister of Māori Affairs, to the Minister of Internal Affairs and to the Otago Museum.

165 Ibid, 76-77.

166 See Ellis, N., La'a Tamarau and Chloe Weavers. 2012. 'Whare for Grabs: The sale of wharenui overseas, 1880-1965'. Indigenising knowledge for current future generations, University of Auckland. p.76.

167 These words feature on the website to promote Mataatua in its new location in Whakatāne (see http://www.mataatua.com/).

168 See Mead, 1990, 98.

169 Ibid. 106.
} 
must return as such and not be classified as an ethnological curiosity to be imprisoned in a museum. Mataatua is a building, a carved meeting house and not an artifact to be locked away. ${ }^{170}$

At a hui with Rongowhakaata and Ngāti Awa held in March 2013 in the Mataatua wharenui Sid Mead, said: "na te raupatu te whare ka riro atu, na te raupatu te whare ka hoki mai." For Sid Mead the Ngāti Awa claim and settlement were about the past, present and future. They were about the responsibility to the past generations and to ensure vitality of Ngāti in the future:

Because a claim to be successful is based on what the past generation suffered and the present generation receiving the settlement becomes the immediate beneficiary that's based on the pain of the generations gone and so they do have a responsibility for the next generations to make sure that that settlement is not just wasted away but it's actually built upon and there is something real for the next generations to inherit... So in a way that drives the whole development push to make sure that there is a future for the iwi, in our case for Ngāti Awa. ${ }^{171}$

Mead reminds us that Mataatua was an 'important pillar' established way back in 1980 and an important cultural icon especially for the younger generation. The central importance of Mataatua as an 'iwi house' is noted by Mead when he says that it reflects the pride of the tribe and the beauty of the culture. For Mead, taonga reflect both the pride of the people and all that is beautiful within the culture as he says:

Well this house is now coming back as an "iwi house" with all the battles that we fought we had to fight on a united front and win it for the tribal authority... So I think that whare best illustrates the importance of taonga to tribal identity the whole tribe identifies with the whare and we've made it clear to everybody that every hapu are owners of that whare and that all nga uri or nga hapu that's their whare... I think that taonga best reflects back to the iwi the underlying beauty of our culture and in this modern world the beautiful part of our culture gets lost in the media hype and all of the practical problems that people are having their struggles and we kind of forget that there are really beautiful things that are part of our culture; and a carved house is definitely one of them, waiata yes, waiata moteatea yes, they are part of the beauty and people do react to those, they love hearing them, the performing arts are all part of it and what else. But again it's all of the taonga aspect that best reflects the pride of an iwi in itself. If it has that pride, it's going to develop carving, it's going to see that its houses are carved and if they are not carved they will start working on them you know to carve them. ${ }^{172}$

In a similar way to Te Aitanga-a-Hauiti, Mead refers to the term 'Ngāti Awatanga' as a way of describing Ngāti Awa cultural heritage. For Mead, this also includes the state of the Māori

\footnotetext{
170 Ibid. 106-107.

171 Sid Mead interview, $4^{\text {th }}$ August 2011.

172 Ibid.
} 
language in Ngāti Awa; the waiata singers, the speakers on the paepae and the kaikaranga. ${ }^{173}$ Clearly, for Mead the developmental dimension of Ngāti Awa includes cultural foundations where taonga are important pillars. If one was to extend the rationale for why Apirana Ngata instigated the building of meeting house in the 1920 s to '40s to revitalize and strengthen Māori identity, then the return of Mataatua is as vital to Ngāti Awa's tribal identity future as it was to their past.

In a video clip on Mataatua that forms part of the communications of the Ngāti Awa tribe, the following is narrated by Pouroto Ngaropo, a prominent Ngāti Awa tribal member. These words speak about the reconnection with their ancestral meeting house and reaffirm the Ngāti Awa cultural reasons stated in 1984 with regard to Mataatua:

After 117 years our whare, our ancestors are able to come home. Mataatua's long journey is almost over. A dozen years have passed and with it a healing of wounds and a rejuvenation of our wharenui. Fresh carvings have been hewn under the guidance of the master carver Te Hau o te rangi Tutua who has now passed on. Mataatua has been given new life by its people. Now it's time for the wandering carved meeting house to rise up again in the heart of Whakatane, its turangawaewae and place where it all began. ${ }^{174}$

In 2010, Sir Wira Gardiner spoke about the 'cultural anchors' of Ngāti Awa, such as Putauaki the mountain, the awa and Kokohinau marae. For Wira, these were not negotiable as this was Ngāti Awa's future. No doubt included in this would be Mataatua as a cultural anchor of Ngāti Awa. ${ }^{175}$ Ngāti Awa's future development is expressed in the Ngāti Awa video that promotes their tribal future 'Ko Ngāti Awa te toki: Te Tirohanga whakamua: Our future, Looking ahead. ${ }^{176}$ The words emphasize the tenacity and endurance of Ngāti Awa and their relationship with their taonga:

Ngāti Awa is the adze whose bindings cannot be loosened by the sun or softened by the rain ... We move forward holding those taonga important to us whilst maintaining our wairua, our manaaki and aroha for all people.

\section{Analysis and Discussion}

For Ngāti Porou and Te Aitanga-a-Hauiti, the repatriation of taonga is about informing, educating and introducing their tribal taonga to their tribal people. Irrespective of age as

173 Ibid.

174 See Mataatua: The house that came home at http://www.mataatua.com/. Uploaded on $15^{\text {th }}$ June 2011.

175 The Te Pourewa Arotahi: The Elevated Platform for Resolution Symposium was held at the Museum of New Zealand Te Papa Tongarewa on $29^{\text {th }}-30^{\text {th }}$ November 2010.

176 Ko Ngāti Awa te Toki is Ngāti Awa's vision for the future up to the year 2050. (See http://www.Ngātiawa.com/.). 
Mahuika says, taonga embody notions of tapu, mauri, wehi and mana and are about cultural heritage and identity. ${ }^{177}$ Ngāti Porou view their tribal taonga as of enduring significance, as reflected in Māori terms such as 'ko ngā taonga tūturu o Ngāti Porou' and the word 'toitū' which translates as 'enduring'. In what seems like an extension to Apirana Ngata's legacy, Ngāti Porou continue to place high value on their culture and taonga as central pillars for Ngāti Porou's development future. The letter of commitment in Ngāti Porou's Deed of Settlement articulated the importance of Ngāti Porou tribal taonga and their place in Ngāti Porou's world.

For Te Aitanga-a-Hauiti, the basis of their engagement with themselves more than anything else has been through their arts and the foundational core of that has been the teaching of the Te Rāwheoro Whare Wānanga. For Wayne Ngata, the well-known waiata tangi of Rangiuia for his son Tuterangiwhaitiri remains a strong ethos for tribal descendants today and is what to him defines his tribal taonga and cultural heritage. 'Kia tipu te whaihanga e hika ki Ūawa' expresses a tribal strategy that emphasizes the importance of arts and creativity in their tribal future. As noted by Wayne Ngata and tribal members, Te Aitanga-a-Hauiti they have been gathering remnants of that body of knowledge together to underpin their tribal development.

Te Aitanga-a-Hauiti has embraced modernity as evidenced by their involvement in innovative technologies and research projects, including virtual repatriation kaupapa and collaborative partnerships with prestigious universities and museums. They have extended their reach into innovative digital initiatives, but at the core of their development journey have been the teachings and traditions of their ancestors and their house of learning, Te Rāwheoro Whare Wānanga. Te Aitanga-a-Hauiti taonga are seen as signposts and cultural icons of where they have come from and where they are going to. As noted by Wayne Ngata, the taonga are seen as physical embodiments of knowledge and are strongly positioned within the pursuit of education. Connecting the people with that body of knowledge and the legacy of the Te Rāwheoro Whare Wānanga is important for the people of Ũawa and descendants of their eponymous ancestor Hauiti.

The politics of Rongowhakaata tribal identity and development have been manifested in more recent times through the mana of their tribal taonga Te Hau ki Türanga. Te Hau ki Türanga is a key symbol of Rongowhakaata's past injustices and the reconciliation and healing of their tribe's cultural future. The central positioning of Te Hau ki Türanga within the

177 Mead,2011, pp.497, 501. 
Rongowhakaata Waitangi Tribunal claim process, including all the meetings on marae and with Government agencies, indicate the significance of this taonga for the Rongowhakaata people. Its central positioning for the Rongowhakaata iwi is seen on the tribal website and heard aloud on the Te Matatini Māori performing arts stage. The initialing of the Deed of Settlement at Te Papa in July 2011 was highly symbolic given its past history with the Crown, but more importantly highlighting its significance for a new and revitalized Rongowhakaata future.

The signing of the Deed of Settlement at the Whakatō marae, Manutūke in September 2011, along with the display of taonga loaned for the occasion, brought the reality of the historic injustices to the present and highlighted the continuing significance of tribal taonga to the people. The apology by the Minister of Treaty Issues for past wrongs, including the taking of Te Hau ki Türanga, was a poignant moment. The six R's that Rongowhakaata negotiators discussed in the meetings leading up to the Deed of Settlement speak directly to the strong relationship of Rongowhakaata tribal and hapu identity and the future aspirations of the people. ${ }^{178}$ Restoring, returning and revitalizing speak directly to countering the colonization process of indigenous peoples, as highlighted by Linda Smith.

The haka performed by the Rongowhakaata kapa haka group of Manutūke Tū Te Manawa Maurea dramatically illustrates the ongoing significance of Te Hau ki Türanga for Rongowhakaata's younger generations. Like Te Aitanga-a-Hauiti's contemporary adoption of the teachings of the Te Rāwheoro Whare Wānanga, there is a plea for Rongowhakaata to return to wānanga as a process that can help Rongowhakaata for the future. The positioning of Te Hau ki Türanga as a tribal taonga that can heal and revitalize Rongowhakaata into the future resonates in the haka composition by the kapa haka group Tu Te Manawa Maurea. Te Hau ki Türanga is central to Rongowhakaatatanga as seen in the words " "Ko Te Hau ki Tūranga. Ko taku tīpare whakarei, taku Manawa, manapou o te iwi" (Te Hau ki Tūranga is my identity, my heart, the essence of my people).

In the case of Ngāti Awa, their wharenui Mataatua was seen as an important pillar in 1980 when there was a major push to unite the people. Today it is seen by both young and old as a 'cultural icon' and there is great excitement in that it reflects the value of tribal taonga that symbolize what happened to the iwi in the past. As Mead reminds us, the taonga best reflects back to the iwi the underlying beauty of the culture and the pride of the iwi. 'Ngāti

178 The six R's include Relate, Return, Repatriation, Restoration, Review and Relationship. 
Awatanga' is the term that Ngāti Awa uses to describe their cultural heritage and this is similar to other tribes, such as Ngāti Kahungunu, Ngāi Tahu and Te Aitanga-a-Hauiti. The future development dimension of Ngāti Awa places great importance on Ngāti Awa cultural dimensions, such as the language, tikanga and Ngāti Awa taonga. As noted in Ngāti Awa's 'Ko Ngāti Awa te toki', the tribe take hold of their taonga yet maintain core values, such as wairua, manaaki and aroha.

Both Sid Mead and Wayne Ngata stressed the importance of education in developing their people for the future and that building cultural capacity was an important part of this. For Te Aitanga-a-Hauiti, their tribal taonga are central to their tribal identity as they are seen as physical manifestations of ancestral traditions and teachings. For their tribe, taonga and the arts play a pivotal and central role in helping to shape the future of Te Aitanga-a-Hauiti. For Ngāti Awa, Mataatua is seen as a cultural icon and symbol that both reflect the pains of their past and the aspiration for a stronger and better cultural future. Mataatua is regarded as an

\section{Conclusion}

Te Aitanga-a-Hauiti's involvement and engagement in their arts and taonga projects is their strong association to the legacy of the Te Rāwheoro Whare Wānanga or House of Learning. The words and concepts that the tribe uses, the way that the tribe promotes the projects and the focus on education and knowledge have direct association to the Te Rāwheoro Whare Wānanga and its teachings. Te Aitanga-a-Hauiti have drawn from the rich artistic traditions of the Whare Wānanga and of Te Rāwheoro, and applied and continued them in a contemporary setting. The names of the various arts strategies and initiatives that Te Aitangaa-Hauiti have adopted have deep historical foundations, but are being actively used in modern times. Terms such as 'Te Kahawhitia', 'Te Pou o Te Kani' and 'Te Whatakōrero' are sourced from their historical past and wānanga foundations. Like Ngāti Kahungunu, Te Aitanga-aHauiti use taonga as a conceptual device reaching back in time to find strategies for the future. The kupu and language is sourced from the historical past as powerful symbols to nourish and revitalize their contemporary lives. Te Aitanga-a-Hauiti has drawn upon tribal concepts, names and events like Te Whatakōrero and Te Kapuārangi from their rich past to revitalize and launch their cultural and economic futures.

Ngāti Awa's experience with regard to Mataatua has similarities to Ngāi Tahu's Waitangi Tribunal claim in that they had tenacity and perseverance in not letting it go. Ngāti Awa 
continued to push for justice against what seemed like insurmountable odds even when Government Ministers believed they had no chance. Survivance and dogged tenacity by Ngāti Awa ensured that Mataatua and all the wandering ancestors would one day come home. As the Te Kerēme or claim became the code word for resilience and tenacity for Ngāi Tahu, so too did Mataatua become a unifying symbol for a revitalized Ngāti Awa identity where the adze bindings cannot be loosened by the sun or softened by the rain. For Rongowhakaata Te Hau ki Turanga is firmly entrenched and positioned in the future development of Rongowhakaata. It stands both as a powerful and significant tribal identity marker of the past and a revitalized symbol of the hopes and aspirations of its people for the future. 


\section{Kupu Whakamutunga - Conclusion}

\section{Taonga - An Enduring legacy}

This research thesis sought to understand the role that Māori taonga play both historically and within contemporary Māori communities as part of their tribal self-determination and the advancement of Māori development and identity. The questions that framed the research were: what is the nature of Māori taonga and what is their relationship with the politics of Māori identity and development? A secondary question posed was: what value are museums, collections of taonga or other cultural heritage in the process of iwi development, which is taking place during and after the settlement of Waitangi Treaty claims?

The thesis investigated the role and place of taonga within the Māori world through their relationships and interconnectedness with Māori culture through 'insider' tribal perspectives. Tribal visions, strategies, policies and projects were examined, along with Waitangi Tribunal claims, tribal exhibitions and taonga-related projects. The research sought to understand the role and place of taonga in developing sustainable economic, social and cultural elements. My initial research was based on key framing questions that explored and examined the relationship between Māori tribal identity and development through the agency of taonga and how taonga in museums are increasingly seen as a resource by Māori for revitalising their tribal identity and development. The research examined taonga within museum contexts, as well as in tribal territories, from where their cultural values and knowledge systems are arguably given the fullest meaning and expression. The Te Mãori exhibition was a watershed moment in our nation's history and helped transform museum practice and stimulate pride and self-determination for tribes embarking on planning their cultural futures.

The question of the role and value that taonga play in the Māori world is a critical dimension of this research and helps to address a major gap in the literature that was identified by the Māori academic Paul Tapsell when he noted: "Not yet fully explored in museological discourse is the equally important ancestral relationship by which museum-held objects are 'valued' within their respective source communities.",

The research methodology adopted a multi-disciplinary approach in museum studies, Māori studies, cultural studies and related disciplines. The main research methodology that was adopted for this thesis was kaupapa Māori, which is a critical theory discourse based directly

1 Tapsell, 2011. 
on Māori lived realities and experiences that recognises the validity of Māori knowledge, traditions and customary concepts. Given that the research has Māori at the centre, it was deemed necessary to advocate for a Māori-oriented framework and paradigm that ensured relevancy, meaning and value from within the culture itself. Adopting this approach ensured that the insider tribal perspectives were given full recognition on their own cultural terms and framed within their own cultural worldviews and nuances.

My experience at the Museum of New Zealand Te Papa Tongarewa working with iwi over the last 20 years also provided me with an opportunity for a self-reflexive ethnographic approach based on my interactions with iwi on a range of tribal projects. The tribal case studies provided a great opportunity to examine in depth the role and place of taonga and cultural heritage for these tribes. Without exception, all iwi placed great emphasis on the culture as being an important element for both their identity and future development.

Adopting Jeffrey Sissons 'recognition of indigeneity', the tribal case studies emphasized that "Indigenous reappropriations represented futures redirected.",

Through the case studies examined, the research shows that Māori see taonga not disconnected from the past but rather as enduring cultural symbols and markers of tribal history and identity that connect the past with the present and future. It also reaffirmed the writing of Appudurai when he said that the cultural past and cultural future are mutually linked. ${ }^{3}$ In the context of contemporary Māori social and economic development, it became apparent that taonga form an important dimension of cultural heritage and are being used in a range of ways, including identity-making, artistic reclamation, cultural tourism, relationshipbuilding, health and economic tribal development.

Māori see taonga as being both from the old world (the past) and the present and future worlds. Taonga are powerful symbols that are heard at Waitangi Tribunal hearings being actively associated with tribal history and identity, cultural renewal, revitalization and tribal development initiatives under cultural redress. With the Waitangi Tribunal claims settlement process, we see the growing organizational capacity of iwi organizations and the growing of skills capacity, fiscal capacity and relationships with international corporations. The future

See Sissons, 2005.

See Appadurai, 2002. 
state for Māori sees more highly developed tribal organizations that have common interests in their cultural heritage with strong political advocacy and relationships at national and international levels.

The diagram of the representation of the interconnectedness of taonga in Chapter One, as informed through models including Higgins' 'He tihi tangata' and Durie's 'Whare tapa wha', along with a synthesis of Māori tribal perspectives, shows the significance of taonga for Māori. Taonga are best understood within their own cultural values and knowledge systems and are connected to multi-dimensional relationships. Whakapapa, mana, kaitiakitanga, mauri, kōrero and whanaungatanga are important values of taonga and the diagrammatic representation of the interconnectedness of taonga in Chapter One reflects this. This supports Durie's Whare Tapa Wha and Te Pae Mahutonga models, which are used to express the significant components of health and identity, including the notion of a secure Māori identity. As a result of the research, there is a clear and demonstrable affirmation that taonga have an enduring and interconnected relationship with Māori with regard to the politics of Māori identity and development.

The relationship between Māori and their taonga, their connections and relationships to the past and future and their significance to their descendant kin communities is well stated by the Te Roroa tribe when, in their Waitangi Tribunal claim they stated "The physical presence recalls the name, The name recalls the event, The event recalls the whakapapa, The whakapapa recalls the connection between things past and things present and the connection between things past and things present is the element which gives Te Roroa its pride and identity."

In Chapter Four we saw how Ngāti Kahungunu taonga are markers of hapū and tribal identity, linking the past with the present. We see the adoption of Ngāti Kahungunu words 'taku wahine purotu, taku tane purotu' as a framework emphasizing the importance of culture for Ngāti Kahungunu. Tūria's comments regarding photographs of Whanganui tipuna show the ongoing relationships with those who are no longer with us and their living descendants today. This was a common theme with the Carnell photographs of Ngāti Kahungunu ancestors in the Kahungunu Ka Moe, Ka Puta exhibition. Likewise, for Ngāi Tūhoe we hear of the importance of taonga returning home where they can become taonga in the hands of their people. The unique Tūhoe concept of matemateaone reminds us of the importance of 
place and the connections and relationships to the land, people and taonga of Tūhoe and Te Urewera, as reinforced by spiritual, psychological and cultural bonds.

The contribution to new knowledge that this research provides is a far greater understanding and knowledge of the relationship between taonga, Māori people and the Māori world. The tribal case studies have seen transitions from the politics of resistance to the pragmatics of partnerships and creative engagement, and the generational growing of organizational capacity and self-determining futures. Some of the directions that have emerged in iwi heritage strategies are the development of cultural centres, centres of excellence, innovative digital access and database projects, partnerships with public institutions and Crown agencies and strong relationships between taonga tuku iho and contemporary art practice. The literature and feedback from tribal members confirm the enduring significance of taonga to whānau, hapū and iwi.

The research demonstrates the centrality of Māori identity and culture in the advancement of Māori development and by association the importance of taonga in the identity-making process. Māori tribal development aspirations show strong similarities and common themes, although these are expressed within their own tribal language. Without exception, all the tribes that were examined express the importance of culture and identity as an important pillar and foundation of their future development. The inter-generational sustainability of knowledge, traditions, tikanga, arts and culture is of high importance for the tribes and a necessary dimension for a secure Māori identity. Tribal members were unanimous in their calls for development to proceed, but not at the expense of abandoning their culture and identity. Quite to the contrary, many tribes asserted their development futures in cultural terms such as Ngāti Kahungunu with 'Kia maumahara ki te mana āhua ake o Ngāti Kahungunu' - Uphold the absolute uniqueness of the living breath of Kahungunu and to enhance the mana and wellbeing of Ngāti Kahungunu Iwi. Ngāti Kahungunu noted that the arts are the soul of the iwi and that the language, art, waiata, stories and histories are all part of Ngāti Kahungunu's cultural identity.

The research confirms that taonga tuku iho provide iwi with a way of articulating the values that underpin and/or guide their iwi development strategies, because these are values that are deeply embedded in their historical cultural identity and lived realities. Taonga are symbolic of the values of whakapapa, mana and whanaungatanga and represent cosmology and genealogy, wairua or the spiritual dimension, the connection to place, and the responsibilities 
and obligations to people. The research demonstrably shows that taonga contribute to tribal development strategies through exhibitions, repatriation, reconnecting with collections in museums and participating in their care, and also through establishment of cultural centres, and as symbols of whānau, hapū and iwi identity (all interconnected). By connecting iwi with others regionally, nationally and internationally physically and online, taonga become a focus for learning and transmitting knowledge intergenerationally, linking people to places and a sense of continuity of occupation (mana whenua). Taonga are seen as physical manifestations of ancestral traditions and teachings as they are about their ancestors and lives. Te Aitanga-aHauiti's Toi Hauiti "living the legacy" and Te Ataakura initiatives are examples that recognize the knowledge and traditions of the past and their influence in shaping the future.

The examination of tribal development strategies and visions through a case study analysis have shown how the future tribal imaginations are being aligned to their past. In most cases, these tribal visions adopted taonga as concepts that reached back in time providing a whakapapa or relationship to today's contemporary world. Tribes used a range of kupu, concepts and waiata to tie the contemporary activity back to traditional roots and thus anchor the present in the past. The research provided a new indigenous vocabulary regarding taonga. The adoption of the ancient waiata oriori, 'Pinepine te kura', for example, provided Ngāti Kahungunu with a conceptual framework and terminology to express the philosophy of Ngāti Kahungunu and projects within the tribe.

The relationships of taonga with tribal histories and traditions also showed their connectedness to constructions of modern tribal identity, as was seen with Te Aitanga-aHauiti and their cultural heritage initiatives. Reuniting Hauiti people with their taonga was and continues to be a powerful tool in fostering self-belief and tribal pride within the community, as expressed by tribal members. The research evidence shows that Te Aitanga-aHauiti tribal taonga are central to their tribal identity, as they are clearly seen as tangible and intangible manifestations of ancestral traditions and teachings that emanated from the Te Rāwheoro Whare Wānanga. Kia tipu te whaihanga e hika ki Ūawa emphasizes a tribal strategy that is based on learning and the creative arts of the Te Rāwheoro Whare Wānanga. This is seen as pivotal and central in helping to construct what it is to be Te Aitanga-a-Hauiti. The inseparability of the stories that convey the language help to show the power of taonga 
sourced from a deep and continuous history. In support of Kreps ${ }^{4}$ argument, Te Aitanga-aHauiti adopted their own cultural approach for their tribal development and worked with museums as a platform for this development.

The main Māori concept that emerged from the research is that of mana - the mana of taonga, the mana of the gods, the mana of the land, the mana of the people and culture. Mana and its wider definitions and associations, including mana atua, mana tangata, mana whenua, mana taiao, mana Māori, mana motuhake and mana tuturu, are vital dimensions in the Māori world. The enduring dimension of this important concept prevails in all the case studies. For Ngāti Porou, Mahuika reminded us that the return of taonga is about informing, educating and introducing Ngāti Porou to their tribal taonga and the taonga to their tribal people. This equally applied to Ngāti Awa regarding Mataatua and Te Aitanga-a-Hauiti and their digital repatriation initiatives. The concept of mana and its 'enduring significance' was an important feature in the letter of commitment in Ngāti Porou's Deed of Settlement where it encapsulated the words 'Ko nga taonga tuturu o Ngāti Porou'. In a continuation of Apirana Ngata's legacy, Ngāti Porou place high value on their taonga as central pillars and dimensions for Ngāti Porou's development future. The letter of commitment in Ngāti Porou's Deed of Settlement illustrated Ngāti Porou's relationship with their taonga in advancing sustainability in economic, social and cultural terms. Shane Jones reminded us that the importance of the settlement of historical grievances is bound up with the affirmation of mana and the transfer of capital and that development cannot be sustainable if mana is not left intact.

The guiding ethos of Ngāi Tahu was informed by kupu korero that derive from their historic past - 'Mō Tàtou, ā, mo kā uri à muri ake nei'. The Ngāi Tahu claim spoke strongly about the identity of Ngāi Tahu and for a renegotiated future. The claim became the code word for resilience, tenacity and the expression of Ngāi Tahu identity. The Treaty post-settlements phase has seen tribes growing their skills and capability to further advance their tribal development aspirations where culture and identity play a central focus.

The examination of Rongowhakaata and Ngāti Awa centred primarily on their treasured wharenui Mataatua and Te Hau ki Tūranga. For both of these tribes, these taonga embodied reconciling sad and tragic histories, yet provide a basis for a renewed and revitalized future. The wharenui Te Hau ki Türanga is central to Rongowhakaatatanga, as seen in the words of

4 See Kreps 2003. 
the haka composed by the Rongowhakaata Kapa Haka Group Tu Te Manawa Maurea - "Ko Te Hau ki Tūranga. Ko taku tīpare whakarei, taku Manawa, manapou o te iwi”" (Te Hau ki Türanga is my identity, my heart, the essence of my people). In adopting Pearce's ${ }^{5}$ writing on the power of objects, the evidence of tribal perspectives positions the wharenui as having the power to carry the past into the present by virtue of its real relationships to past events.

In the same way that Ngata saw the building of wharenui as a way to enhance the culture and pride in Māori in a developmental way, the same can be said of Mataatua when Ngāti Awa say that Mataatua will be the focus for the tribe to help lift the mana and self-esteem of all Ngāti Awa hapū. As noted in Chapter Five, Mataatua was a unifying house when it opened in 1875 and once again it will be a unifying house for Ngāti Awa and all of Mataatua. This aligns well with the writing of Sissons when he discusses dispossession and repossession and says: "If colonisation was and is dispossession, then the futures of first peoples will be built on repossession." 6

This research has contributed to new knowledge in that it provides quantitative and qualitative data with respect to the relationship between Māori and their taonga. It provides depth in the tribal understanding of taonga, along with how tribes view taonga in their future imaginations. The research has shown that taonga are symbols and icons of tribal identity that help to resolve and heal the brokenness and fractures of colonial experience. Mataatua and Te Hau ki Türanga are powerful examples of this. It speaks directly to the title of this thesis when Linda Smith made the comment about the scattered nature of tribal taonga and the importance of healing this rupture: "Bits and pieces all over the place - making us whole again." This research provides a basis on which we can indeed be made whole again. Having a secure Māori identity in Durie's thinking helps to correct and heal this rupture and provide for a healthier identity and more confident future. Since many of the taonga projects examined have in some way an association with museums, the research will also help to fill a void in the literature with respect to museum-iwi relations, as noted by Paul Tapsell. The research also contributes to new knowledge by expanding museum studies, cultural studies and development studies in the development of a living contemporary culture. This research expands museum studies with particular reference to museums and source communities by providing Māori tribal experiences and realities that focus on cultural heritage and social, economic and cultural development.

\footnotetext{
Pearce, 1992.

6 Sissons, 2005.
} 
With regard to the research question the interviews have provided a deep understanding of a tribe's relationship and connectedness with their taonga and cultural heritage. Many tribes used the word toitū in relation to their taonga to express the relationship with the past, present and future. For Ngāti Porou people the Māori terms 'taonga tūturu' and 'toitū' are critical to their tribal understanding of Ngāti Porou taonga. Large taonga like the meeting houses Te Hau ki Türanga and Mataatua are seen not only as powerful and enduring symbols of the past but taonga that can shape and revitalize tribal futures. The relationship between tribal taonga and the politics of Māori identity and development is strongly expressed and embedded in cultural historical terms like that of Ngāi Tahu's Mō Tatou and the Te Rāwheoro Whare Wānanga of Te Aitanga-a-Hauiti. In addressing a gap in the literature the interviews categorically and demonstrably illustrate the centrality of taonga within the broader understanding of culture as an important pillar of development. The research through the tribal interviews demonstrates the role taonga play in sustaining the inter-generational continuity of tribal culture. Their interviews confirm the 'connectedness' of taonga to the wider culture, including the pivotal role they play in informing and shaping tribal development futures.

In some ways, iwi are still on the cusp of deciding how to progress their cultural heritage aspirations and are considering their best options with some working in partnership with museums and some choosing their own futures, while others embark on new heritage projects to provide work and revenue for their people. Although the findings of this research demonstrate that iwi recognise the importance of taonga in sustaining their culture, the future is far from certain. There are difficult choices to be made and those choices may take some time to clarify. One has only to look at how long Ngāti Kahungunu have been planning for a cultural centre or how big the challenge will be if Rongowhakaata bring their wharenui Te Hau ki Türanga home. The path forward has a note of caution and challenge for iwi to fully realize the potential of their taonga to sustain them as they meet the challenges of the future. This research shows that iwi will continue to explore the ways in which they are able to work with museums and it is clear that this will be an ongoing process. If the past is anything to go by, iwi will have the determination and tenacity to pursue their cultural aspirations with hope and confidence. 


\section{Papakupu - Glossary}

\section{Kupu Māori (Māori word) Whakamārama (Explanation)}

Aotearoa

Aroha

Hawaiki

Hingāngāroa

Ihi

Kaitiaki (Kaitiakitanga)

Kaupapa

Mana

Mana atua
New Zealand

Love, respect

Ancestral homeland of Māori; spiritual homeland believed to be in Polynesia

Tohunga of great renown from Ūawa, Tolaga Bay

Excitement

Guardian, to care for, look after. The Waitangi

Tribunal Wai 262 Report (p.7) noted that kaitiaki are those who have a special relationship with a taonga which gives rise to an obligation and corresponding right to protect, control, use, preserve, or transmit the taonga itself and also the relationship of kaitiaki to the taonga. Stewardship and protection are key concepts and often in association with natural resources. ${ }^{7}$

Strategy, subject, theme

Mana has been described by Barlow as 'the enduring power of the gods and the sacred fire that is without beginning and without end. He notes that in modern times it has taken on various meanings, including the power of the gods, the power of the ancestors, the power of the land and the power of the individual. ${ }^{8}$

The sacred power of the gods

See Law Commission Study Paper 13, 2002.

See Barlow 1991, 61. 


\section{Kupu Māori (Māori word) Whakamārama (Explanation)}

Mana motuhake

Mana taiao

Mana tangata

Mana tipuna

Mana whenua

Manaaki (manaakitanga)

Māoritanga

Māori

Mātauranga Māori

Matemateaone

Mauri

Ngāi Tahu

Ngāti Kahungunu
Spirituality set apart

The power and authority of the environment

The power and authority of the individual

The power of the ancestors as passed down from generation to generation

The power and authority of the land. Barlow says that it is "the power associated with the possession of land'. ${ }^{9}$ Whenua is also the Māori term used to describe the afterbirth and placenta and hence its sacred association.

To care for, look after

A term used to describe those aspects that collectively make up Māori identity and culture

The indigenous peoples of Aotearoa New Zealand Māori knowledge. This also extends to mātauranga-aiwi, which is Māori tribal knowledge.

A distinctly Ngāi Tūhoe term that affirms the importance of place and locality to Tūhoe identity

Life-force, life-giving essence

A major tribe of the South Island

A large tribe on the East Coast of the North Island from Wairoa in the north, through Hastings to the Wairarapa

9 Barlow 1991, 61. 


\section{Kupu Māori (Māori word) Whakamārama (Explanation)}

Noa

Pātaka

Poupou

Poutokomanawa

Rongomaiwahine

Rongowhakaata

Taiao

Takitimu

Taonga

Taonga-tuku-iho

Tangata whenua

Tapu

Te Aitanga-a-Hauiti

Te Hau ki Tūranga
Free from tapu

Storehouse

Carved ancestral wall post figure that represent an ancestor

Centre post figure that supports the ridgepole in the interior of a meeting house

The eponymous ancestor of Mahia, Northern Hawke's Bay

A tribe that is situated near Manutūke, Gisborne

The environment

The ancestral voyaging waka of the East Coast tribe Ngāti Kahungunu, along with Ngāti Ranginui, Te Aitanga-a-Mahaki and Ngāi Tahu

A highly prized possession; something of value Highly prized object that has been handed down from the ancestors

People of the land. The indigenous people of Aotearoa New Zealand

Sacred

The descendants of the ancestor Hauiti; a tribe that reside at Ūawa, Tolaga Bay

The Rongowhakaata meeting house that is presently on display in the Museum of New Zealand Te Papa Tongarewa 


\section{Kupu Māori (Māori word) Whakamārama (Explanation)}

Te Pae Māhutonga

Te Rāwheoro

Tipuna

Toitū

Tuakiri

Turangawaewae

Wairua

Wehi

Whakapapa

Whanaungatanga

Wharenui

Whare wānanga
The Southern Cross star constellation

A well-known whare wānanga or centre of learning at

Ūawa, Tolaga Bay

Ancestor

Enduring, permanence

Māori term that is used to refer to 'identity'

Place of belonging, place to stand

Spirit; 'taha wairua' means the spiritual dimension

Fear

Genealogy, relationships

Relationships

Meeting house

House of learning 


\section{Rārangi Pukapuka - Bibliography}

\section{Interviews}

Kopua, Mark. 23 ${ }^{\text {rd }}$ September 2011.

Mead, Sid. $4^{\text {th }}$ August 2011.

Ngata, Wayne. $19^{\text {th }}$ December 2011.

O'Regan, Tipene. $5^{\text {th }}$ October 2011.

Parata-Goodall, Puamiria. $5^{\text {th }}$ October 2011.

Sciascia, Piri. 15 ${ }^{\text {th }}$ August 2011.

Solomon, Mark. $3^{\text {rd }}$ October 2011.

Soutar, Monty. $18^{\text {th }}$ August 2011.

Tamati-Quennell, Megan. $18^{\text {th }}$ November 2011.

Terrell, John. 1991.

Tomoana, Ngahiwi. $8^{\text {th }}$ September 2011.

Whaitiri, Meka. $6^{\text {th }}$ October 2011.

Wyllie, Jody. 29 $9^{\text {th }}$ September 2011.

\section{Unpublished references}

Aratoi: Wairarapa Museum of Art and History Events Programme 2004.

Ballara, Angela Heather. 1991. The Origins of Ngāti Kahungunu. PhD, Victoria University of Wellington, Wellington.

Butts, David. 2003. Māori and Museums: The Politics of Indigenous Recognition. PhD, Museum Studies, Massey University, Palmerston North.

Carroll, Rowan Amber. 2008. The Acquisition of the Partington Collection by Whanganui Regional Museum: Valuing Relationships in museum policy and practice. MA, Museum Studies, Massey, Palmerston North.

Carter, Lyn. 2010. Travelling beyond landscapes: Ngāi Tahu rock art and its role in reaffirming Ngāi Tahu identity and engagement with cultural landscapes. In Manu Аo.

Carter, Lynette, Rawinia Kamau, and Mereana Barrett. November 2011. Te Pae Tawhiti Māori Economic Development Programme Literature Review and Programme Report. Nga Pae o te Maramatanga. The University of Auckland: Norcross.

Emery, Debra Joy Te Pora. 2008. E Hoki ki tō Maunga: The Quintessential Elements of Home. PhD, University of Waikato, Hamilton.

Evatt, Burleigh. 12 May 2010. Māori Enterprise and the New Zealand Capital Markets: Scoping Report. Te Puni Kokiri.

Gonzalez, Christina M. 2010. 'Be(com)ing' Ngāti Kahungunu in the Diaspora: Iwi Identity and Social organisation in Wellington. MA, Māori Studies, Victoria University of Wellington, Wellington.

Hamer, Paul. 2007. Māori in Australia: Nga Māori i te ao Moemoea. Edited by Te Puni Kokiri. Wellington: Te Puni Kokiri. 
Head, Lyndsay. 2006. Land, Authority and the forgetting of being in early colonial history. $\mathrm{PhD}$, Māori Studies, University of Canterbury, Christchurch.

Hedley, R. 2004. "Prototype Theory and the Concept of Taonga: Implications for Treatyrelated Issues such as the Display and Conservation of Taonga Maori." He Puna Korero: Journal of Maori and Pacific Development no. 5 (1):49-68.

Henare, Manuka. 2003. The Changing Images of Nineteenth Century Māori Society: From Tribes to Nation. PhD Māori Studies, Victoria University of Wellington, Wellington.

Higgins, Rawinia.R. 2004. He Tānga Ngutu, He Tühoetanga. Te Mana Motuhake o te Tã Moko Wāhine: The Identity Politics of Moko Kauae. PhD, Te Tumu - School of Māori, Pacific and Indigenous Studies, University of Otago, Otago.

Jahnke, Huia. 2006. He Huarahi Motuhake: The Politics of Tribal Agency in Provider Services. PhD, School of Māori Studies, Massey University, Palmerston North.

Jahnke, Robert. 2006. He Tataitanga Ahua Toi: The House that Riwai built/a continuum of Māori Art, PhD, Māori Studies, Massey University, Palmerston North.

Love, Ngatata. 1998. "Māori Development: The Role of Te Puni Kokiri and the Link to Research”. Paper read at Te Oru Rangahau: Māori Research and Development, at Massey University, Palmerston North.

McCarthy, Conal. 2004. From Curio to Taonga: A genealogy of display at New Zealand's National Museum, 1865-2001. PhD, Museum \& Heritage Studies, Victoria University of Wellington, Wellington.

Ministry of Justice. 2001. He Hinatore ki te Ao Māori: A Glimpse into the Māori World. Wellington: Ministry of Justice.

Moon, Evan Paul. 2004. The Application of Modernisation Theory to Phases in Māori Development since 1800. MA, Te Ara Poutama, Faculty of Māori Development, Auckland University of Technology, Auckland.

O'Regan, Gerard. 1997. Bicultural Developments in Museums of Aotearoa: What is the current status? Ki te whakamana i te kaupapa Tikanga-a-rua ki roto i Nga Whare Taonga o te Motu: Kei hea e tu ana? Wellington: Te Papa National Services Te Paerangi, Museums Association of Aotearoa.

O'Sullivan, John Gerard. 2005. An Investigation into the process of Māori Economic Development. MA, Lincoln University, Christchurch.

Pishief, Elizabeth Dale. 2012. Constructing the Identities of Place: An Exploration of Māori and Archaeological Heritage Practices in Aotearoa, New Zealand. $\mathrm{PhD}$, Museum Studies, Victoria University of Wellington, Wellington.

Puketapu, Brendon. 2000. Māori Organisation and Contemporary Māori Development: Strengthening the conceptual plait. PhD, Māori Studies, Massey University, Palmerston North.

Robens, Huria. 2005. Working Collaboratively with Indigenous peoples. In Australian Institute of Aboriginal \& Torres Strait Islanders Library Conference. Canberra, Australia.

Sciascia, Ana. 2011. Iwi Exhibitions at Te Papa: A Ngāi Tahu Perspective. MA, Museum and Heritage Studies, Victoria University of Wellington, Wellington.

Sharples, Pita. 2009. Manu Ao Academy Seminar - 'Māori Development'. Wellington: New Zealand Government.

Smith, Graham Hingangaroa. 1997. The Development of Kaupapa Māori: Theory and Praxis. $\mathrm{PhD}$, Education, The University of Auckland, Auckland.

Soutar, Monty. 2000. Ngāti Porou Leadership: Rapata Wahawaha and the Polictics of Conflict. PhD, Māori Studies, Massey University, Palmerston North.

Tapsell, Paul. 1995. Taonga and Obligations of Reciprocity. MA, The University of Auckland, Auckland. 
Tapsell, Paul. 1998. Taonga: A Tribal Response to Museums. PhD, School of Museum Ethnography, University of Oxford, London.

Te Awekotuku, Ngahuia, and Linda Nikora. 2003. Nga Taonga o Te Urewera: A Report prepared for the Waitangi Tribunal's Urewera District Inquiry, August, 2003 (Wai 894, doc B6).

Waymouth, Lynette Joy. 1998. Waitaha, Katimamoe, Kaitahu: Ko Wai? Waitaha, Katimamoe, Kaitahu: Identity Boundaries. MA, Māori Studies, The University of Auckland, Auckland.

Wyllie, Jody. 2009. Te Hau ki Tūranga Integrity Audit /Ownership Issues Report. Crown Forest Rentals Trust.

\section{Published references}

Abungu, George H. Okelo. 2006. "Africa and Its Museums: Changing of Pathways?” In Art and Cultural Heritage: Law, Policy and Practice, edited by Barbara T Hoffman, 386393. New York: Cambridge University Press.

Alivizatou, Marilena. 2012. "From Artefacts to Communities: Participation and Contestation at Te Papa Tongarewa." In Intangible Heritage and the Museum: New Perspectives on Cultural Preservation, edited by Marilena Alivizatou, 49-76. California: Walnut Creek: Left Coast Press.

Ames, Michael. 1989. Cultural Empowerment and Museums: Opening Up Anthropology Through Collaboration: The University of British Columbia.

1992. Cannibal Tours and Glass Boxes: The Anthropology of Museums. 2nd ed. Vancouver: University of British Columbia Press.

. 2003. "How to decorate a house: The re-negotiation of cultural representations at the University of British Columbia Museum of Anthropology." In Museums and Source Communities: A Routledge Reader, edited by Laura Peers and Alison K Brown, 171-180. London \& New York: Routledge.

Anderson, Atholl. 1998. The Welcome of Strangers: An Ethnohistory of Southern Maori, AD 1650-1850: University of Otago Press.

Appadurai, Arjun. 2002. "Cultural Diversity: A Conceptual Platform - Sustainable Diversity: The Indivisibilty of Culture and Development." In UNESCO Universal Declaration on Cultural Diversity, edited by Katerina Stenou, 9-15. Paris, France: United Nations Educational, Scientific and Cultural Organization.

Armstrong, J. 1997. "Māori Identity in the South Island of New Zealand: Ethnic Identity Development in a migration context." Oceania no. 57 (3):195-216.

Baker, Jade Tangiahua. 2009. "Te Kupenga: Re-casting entangled networks." The Australian Journal of Anthropology no. 20:112-130.

Ballara, Angela 1998. Iwi: The Dynamics of Māori Tribal Organisation from c.1769 to c.1945. Wellington: Victoria University Press.

Barkan, E. 2002. "Amending Historical Injustices: The Restitution of Cultural Property. An Overview." In Claiming the Stones/Naming the Bones: Cultural Property and the Negotiation of National and Ethnic Identity, edited by E. Barkan and R. Bush. Getty Press.

Barker, Ian. 2006. "The Protection of Cultural Heritage Items in New Zealand" In Art and Cultural Heritage: Law, Policy and Practice, edited by Barbara T Hoffman, 145-147. New York: Cambridge University Press.

Barringer, T, and T Flynn. 1998. Colonialism and the Object: Empire, Material Culture and the Museum. London and New York: Routledge.

Basu, Paul, and Wayne Modest. 2014. Museums, Heritage, and International Development. 
London: Routledge.

Battiste, M. 2000. Reclaiming Indigenous Voice and Vision. Vancouver: University of British Columbia.

. 2008. "Research Ethics for protecting Indigenous Knowledge and Heritage:

Institutional and Researcher responsibilities." In Handbook of Critical and Indigenous Methodologies, edited by Norman K. Denzin, Yvonna S. Lincoln and Linda Tuhiwai Smith, 497-510. Los Angeles, London, New Delphi, Singapore: Sage.

Bennett, Tony. 1995. The Birth of the Museum. London: Routledge.

- 2004. Pasts Beyond Memory: Evolution, Museums, Colonialism. London \& New York: Routledge.

_ 2005. "Civic Laboraties: Museums, Cultural Objecthood, and the Governance of the Social." Cultural Studies no. 19 (5):521-547.

Bishop, Russell. 1994. "Initiating Empowering Research?” New Zealand Council for Educational Research no. 29 (1):175-188.

Bishop, R. 1998. "Freeing ourselves from neo-colonial domination in reseach: a Māori approach to creating knowledge." International Journal of Qualitative Studies in Education no. 11 (2):199-219.

_ 2008. "Te Kotahitanga: Kaupapa Māori in Mainstream Classrooms." In Handbook of Critical Indigenous Methodologies, edited by Norman K. Denzin, Yvonna S. Lincoln and Linda Tuhiwai Smith, 439-458. Los Angeles, London, New Delhi, Singapore: Sage.

Bishop, R, and S.J Tiakiwai. 2002. "Building capacity for sustainable iwi development." Journal of Maori and Pacific Development no. 3:31-39.

Borrell, Belinda. 2005. "Living in the City Ain't so Bad: Cultural Identity for Young Māori in South Auckland." In New Zealand Identities: Departures and Destinations, edited by James Liu, Tim McCreanor, Tracey McIntosh and Teresia Teaiwa, 191-206. Wellington: Victoria University Press.Brown, Deidre. 1996. "Te Hau ki Tūranga." The Journal of the Polynesian Society no. 105 (1):7-26.

Brown, Deidre. 1996. "Te Hau ki Tūranga." Journal of the Polynesian Society no. 105 (1):726.

2003. Tai Tokerau Whakairo Rākau: Northland Māori Woodcarving: Reed Publishing.

Butler, P. 1996. Te Māori Past and Present: Stories of Te Māori. MA, Massey University, Palmerston North.

Butts, David. 1990. Nga Tukemata: Nga Taonga o Ngāti Kahungunu/The Treasures of Ngāti Kahungunu. The Politics of the Past. P. Gathercole and D. Lowenthal. London, Unwin Hyman

1994 "Nga Tukemata: Nga Taonga o Ngāti Kahungunu (The Awakening: Treasures of Ngāti Kahungunu)." In The Politics of the Past, edited by Peter Gathercole and David S. Lowenthal, 107-117. London and New York: Routledge. . 2000. "Museums". In Informing New Zealand: Libraries, Archives and Museums, edited by R. McCahon and G. Oliver, 150-160. Wellington: Open Mind Publishing. . 2002. "Māori and Museums: The Politics of Indigenous Recognition". In Museums, Society, Inequality, edited by Richard Sandell, 225-243. London \& New York: Routledge.

- Butts, David. 2003. "Review of Pukaki: a comet returns." Te Ara: Journal of Museums Aotearoa no. 28 (1):50.

2006. "Museum Governance, Indigenous Recognition and (in) Tolerant

Multiculturalism." New Zealand Sociology no. 21 (no.1):89-107. 2007. "Māori, Museums, and the Treaty of Waitangi: The Changing Politics of 
Representation and Control." In Museum Revolutions: How Museums Change and Are Changed, edited by Simon J Knell, Sheila Watson and Suzanne Macleod, 215227. London: New York: Routledge.

Butts, David. 2002. "Māori and Museums: The Politics of Indigenous Recognition." In Museums, Society, Inequality, edited by Richard Sandell, 225-243. London \& New York: Routledge.

Cameron, F. 2000. Shaping Māori Identities and Histories: Collecting and Exhibiting Māori Material Culture from the 1850s to the 1920s. PhD, Social Anthropology, Massey University, Palmerston North.

Cant, Garth. 2005. "Ngāi Tahu and its Eighteen Papatipu Runanga in a contested PostColonial New Zealand." In Discourses and Silences: Indigenous Peoples, Risks and Resistance, edited by Garth Cant, Anake Goodall and Justine Inns, 199-208.

Carter, John. 1994. "Museums and Indigenous Peoples in Canada". In Museums and the Appropriation of Culture, edited by Susan Pearce, 213-226. London: Te Athlone Press.

Carter, Lyn. 2010. "Travelling Landscapes: Rock Art and Ngāi Tahu Identity”. In Beyond the Scene. Landscape and Identity in Aotearoa New Zealand, edited by J Stephenson, M. Abbott and J. Ruru, 167-180. Dunedin: Otago University Press.

Casey, Dawn. 2000. "Indigenous Ownership of Digital Material - Is organised crime getting out of hand?" In ALIA 2000: Capitalising on knowledge Conference, Canberra, October 2000. Canberra.

. 2001. "Museums as Agents for Social and Political Change." Curator no. 44

(3):230-236.

Cassells, Richard. 1985. "Māori 'taonga' and the art gallery/museum dichotomy". AGMANZ Journal,Mar 16.1:25-7.

. 1994. "Otago Museum: The wharenui Mataatua and the Waitangi Tribunal".

Journal of the Art Galleries and Museums Association of New Zealand no. 24 (2):2931.

Cherrington, Lisa, and Bridget Masters. 2005. Literature review of Māori models of health and indigenous injury prevention and health promotion interventions. Prepared for Ronald Karaitiana, Cultural Strategies Manager, Injury Prevention, Accident Compensation Corporation, Lower Hutt.

Conference of Directors of National Libraries in Asia and Oceania (CDNLAO). 2005. Newsletter, no. 52, March 2005.

Clavir, M 2002. Preserving What is Valued: Museums, Conservation, and First Nations. Vancouver: University of British Columbia Press.

Clifford, James. 1988. The Predicament of Culture: Twentieth-Century Ethnography, Literature, and Art. Cambridge, Massachusetts: Harvard University Press.

- 1997. Routes: Travel and Translation in the Late Twentieth Century. Cambridge: Harvard University Press.

Conaty, Gerald T. 1989. 'Canada's First Nations and Museums: A Saskatchewan Experience". The International Journal of Museum Management and Curatorship no. 8 (4):407-413. - 2003. "Glenbow's Blackfoot Gallery". In Museums and Source Communities: A Routledge Reader, edited by Laura Peers and Alison K. Brown, 227-241. London \& New York: Routledge.

2008. "The effects of repatriation on the relationship between the Glenbow Museum and the Blackfoot People”. Museum Management and Curatorship no. 23 (3):245259.

Corin, Lisa G. 1994. Mining the Museum: Artists look at museums, museums look at 
themselves. New York: The New Press.

Corsane, Gerard. 2005. Heritage, Museums and Galleries: An Introductory Reader. London \& New York: Routledge.

Cram, Fiona, and Vivienne Kennedy. 2010. "Researching with Whānau Collectives". MAI Review no. 3:1-12.

Crooke, Elizabeth. 2005. "Museums, communities and the politics of heritage in Northern Ireland". In The Politics of Heritage: The legacies of 'Race', edited by Jo Littler and Roshi Naidoo, 237-255. London: Routledge. . 2006. "Museums and Community". In A Companion to Museum Studies, edited by Sharon Macdonald, 171-185. Oxford: Blackwell Publishing. . 2008. Museums and Community: Ideas, Issues and Challenges. London \& New York: Routledge.

Dacker, Bill. 1994 Te Mamae me te Aroha: The Pain and the Love. Otago: The University of Otago Press.

Davidson, Janet. 1989. Taonga Māori: A Spiritual Journey Expressed through Māori Art. Wellington: Te Papa Press.

Davis, Sharlene. 2006. "Ka Whakaohoake i nga tangata nunui: Māori Economic Development - Awakening the Sleeping Giant." In State of the Māori Nation: twentyfirst century issues in Aotearoa, edited by Malcolm Mulholland, 53-65. Auckland: Reed.

Davis, Peter. 2007. "Place, Exploration: Museums, Identity, Community." In Museums and their Communities, edited by Sheila Watson, 53-75. London \& New York: Routledge.

Davies, Preston, Ralph Lattimore, and Keith Ikin. 2005. "Māori Economic Development: Overview and Prospects in Economic Development in New Zealand". In Economic Development in New Zealand, edited by James Rowe, 107-126. Aldershot: Ashgate Publishing.

Denzin, Norman K., Yvonna S. Lincoln, and Linda Tuhiwai Smith. 2008. Handbook of Critical and Indigenous Methodologies. Los Angeles, CA: Sage.

Diamond, Paul. 2003. A Fire In Your Belly: Māori Leaders Speak. Wellington: Huia Publishers.

Doherty, Wiremu. 2012. "He Rarangi Kaupapa”. In Conversations on Matauranga Māori, edited by Haemata Ltd, Taiarahia Black, Daryn Bean, Waireka Collings and Whitney Nuku, 15-36. NZQA.

Dolan, Janey. 2001. "Previous Possessions New Obligations in Western Australian Community Museums". Open Museum Journal no. 3. hrrp://amol.org.au/craft/omjournal/volume3/dolan.pdf.

Doxtator, D. 1996. "The Implications of Canadian Nationalism for Aboriginal Cultural Autonomy". Curatorship: Indigenous Perspectives in Post-Colonial Societies:56-70.

Durie, E.T.J. 1997. “Governance”. In Strategies for the Next Decade. The School of Māori and Pacific Development, Hamilton, University of Waikato.

Durie, Mason. 1985. "A Māori perspective of health". Social Science Medicine no. 20 (5):483-486.

1993. "Māori and the State: Professional and Ethical Implications for a Bicultural Public Service". Paper read at Proceedings of the Public Service Senior Management Conference, at Wellington.

1994. Waiora Mana-a-Iwi: Māori Development and Health Reforms. Auckland: Oxford University Press.

. 1997. "Representation, Governance and the Goals of Māori Self Determination". He Pukenga Korero, no. 2 (2):1-7. 1998a. Te Mana, Te Kawanatanga: The Politics of Māori Self-Determination. 
Auckland: Oxford University Press.

1998b. "The Treaty Was Always About the Future". In Living Relationships: Kokiri Ngātahi, edited by Ken S. Coates and P.G. McHugh, 189-193. Wellington: Victoria University Press.

. 1999. "Te Pae Mahutonga: A Model for Māori Health". Health Promotion Forum of New Zealand Newsletter no. 49:2-5.

2000. "Toi te kupu, Toi te mana, Toi te whenua: Māori development in a global society". He Pukenga Korero, no. 5 (2):6-7.

.2001a. E Taurangi tonu te hau: the Winds of Change Forever blow: A Mãori

Development Trilogy. Unpublished D.Lit, Massey University, Palmerston North. . 2001b. Mauri Ora: The dynamics of Māori health. Auckland: Oxford University Press.

. 2002a. The CHI Model: A Culturally Appropriate Auditing Model. Wellington: Public Health Commission.

. 2002b. "Tuha-NZ: a Treaty understanding of Hauora in Aotearoa, New Zealand". Health Promotion Forum of New Zealand - Runanga Whakapiki i te Hauora o Aotearoa.

_ 2003. Nga Kahui Pou: Launching Māori Futures. Wellington: Huia Publishers. . 2004. "Exploring the Interface Between Science and Indigenous Knowledge". In 5th APEC Research and Development Leaders Forum - Capturing Value from Science. Christchurch.

. 2004a. "An Indigenous Model of Health Promotion". In 18th World Conference on Health Promotion and Health Education. Melbourne.

. 2004b. "Understanding health and illness: research at the interface between science and indigenous knowledge". International Epidemiological Asociation no. 33:11381143.

2005. “Te Tai Tini Transformations 2025”. In Hui Taumata. Museum of New Zealand Te Papa Tongarewa: Massey University.

_. 2006. "Measuring Māori Wellbeing". New Zealand Treasury Guest Lecture Series. . 2009a. "Pae Mana: Waitangi and the Evolving State". In Te Mata o te Tau Lecture series 2009 on 'The Paerangi Lectures' Māori Horizons 2020 and beyond (14th July 2009).

. 2009b. "Pae Matatū: Sustaining the Māori Estate". In Te Mata o te Tau Lecture series on 'The Paerangi Lectures' Mãori Horizons 2020 and beyond (24th June 2009).

. 2009c. "Pae Ora: Māori Health Horizons". In Te Mata o te Tau Lecture series 2009 on 'The Paerangi Lectures' Māori Horizons 2020 and beyond. $\left(7^{\text {th }}\right.$ July 2009). .2011. Nga Tini Whetu: Navigating Mãori Futures. Wellington: Huia Publishers.

Edwards, William John Werahiko. 2010. Taupaenui Māori Positive Ageing. Doctor of Philosophy, Massey University, Palmerston North.

Ellis, Ngarino, La'a Tamarau, and Chloe Weavers. 2012. Whare for Grabs: The sale for wharenui overseas, 1880-1965. Paper read at Indigenising knowledge for current and future generations, at The University of Auckland.

Evison, Harry. 1986. Ngāi Tahu land rights supplements: a companion to Ngāi Tahu land rights \& the crown pastoral lease lands in the South Island of New Zealand Christchurch: Headlands Publication.

1988. The Treaty of Waitangi \& the Ngāi Tahu claim: a summary Christchurch: Ngāi Tahu Māori Trust Board.

. 1993. Te Wai Pounamu: the greenstone island: a history of the southern Maori during the European colonization of New Zealand, Wellington. Published by Aoraki 
Press in association with the Ngāi Tahu Māori Trust Board \& Te Rūnanganui o Tahu. 1997. The Long Dispute: Mãori Land Rights and European Colonisation in Southern New Zealand. Christchurch: Canterbury University Press. . 2006. The Ngāi Tahu Deeds: A Window on New Zealand History.

Fekrsanati, F., T. Temara, and R. Gabel. 2014. "Te Hono Ki Aotearoa: The link to New Zealand - Kaupapa Waka in the Netherlands". Paper read at ICOM-CC: 17th Triennial Conference Preprints, Melbourne, 15-19 September 2014, at Melbourne.

Fforde, Cressida, Jane Hubert, and Paul Turnbull. 2002. The Dead and their Possessions: Repatriation in Principle, Policy and Practice. London and New York: Routledge.

Finlayson, Chris. 2011. Deed of Settlement signed with Rongowhakaata. New Zealand Government 2011. Retrieved 30th September from http://www.beehive.govt.nz/release/deed-settlement-signed-rongowhakaata.

Friedman, Jonathan. 1992. "The Past in the Future: History and the Politics of Identity". American Anthropologist no. 94 (4):837-859.

1998. "Knowing Oceania or Oceania Knowing: Identifying Actors and Activating Identities in Turbulent times". In Pacific Answers to Western Hegemony: Cultural Practices of Identity Construction, edited by Jurg Wassman, 37-66. New York: Berg.

Galla, Amareswar. 1996. "Indigenous Peoples, Museums and Frameworks for Effective Change". Curatorship: Indigenous Perspectives in Post-Colonial Societies no. 8:8295.

Gathercole, P. 2002. "Te Māori in the Longer View". In Pacific Art: Persistence, Change amd Meaning, edited by Anita Herle, Nick Stanley, Karen Stevenson and Robert Welsch, 271-279. Adelaide, Australia: Crawford House Publishing.

Geismar, Haidy. 2013. Treasured Possessions: Indigenous Interventions into Cultural and Intellectual Property. Durham and London: Duke University Press.

Genoways, Hugh H. 2006. Museum Philosophy for the Twenty-first Century Oxford, UK: AltaMira Press.

Gisborne Herald, "Reasserting mana and a major 'new' attraction." 2011., 27 June 2011, 14. Goodall, Anake. 2005. "Tai timu, Tai pari ... the ever-changing tide of Indigenous Rights in Aotearoa, New Zealand". In Discourses and Silences: Indigenous Peoples, Risks and Resistance, edited by Garth Cant, Anake Goodall and Justine Inns, 185-198. 2009. "Aoraki Matatu - Being steadfast in Ngāi Tahu Identity". In Governing and Running Māori Entities Intensive, edited by Continuing Legal Education, 9-20. Wellington: New Zealand Law Society. . 2011. Mō Tātou - Realising Ngāi Tahu Settlement Potential. Retrived 29 March 2011 from http://www.Ngāitahu.iwi.nz/Events/2009/Forging-Futures/Anake-GoodallAddress.php.

Gorbey, Ken. 1984. "Is There Life After Te Māori?". AGMANZ Journal no. 15 (4 (December)):2-3. . 1991. "The Challenge of Creating a Bicultural Museum". Museum Anthropology no. 15 (4):7-8.

Gottfried Lindauer: Te Renitawa. The Shadow Maker exhibition catalogue published by the Hawke's Bay Cultural Trust, 2005.

Griffin, D. 1996. "Previous Possessions, New Obligations: A commitment by Australian Museums". Curator no. 39 (1):45-62.

Gurian, Elaine. 1999. "What is the object of this exercise? A meandering exploration of the many meanings of objects in museums". Daedalus no. 128 (3):163-183. . 2002. "The Many Meanings of Objects". In A paper presented to the Choices \& Challenges: Collecting by Museums and Archives Symposium Dearborn, Michigan, USA. 
2005. "A Blurring of the Boundaries". In Heritage, Museums, and Galleries: An Introductory Reader, edited by G Corsane, 71-77. New York: Routledge. . 2005. "Coming Full Circle". In The Native Universe and Museums in the TwentyFirst Century, edited by Mark Hirsch and Amy Pickworth, 13-25. Washington, D.C., and New York: National Museum of the American Indian.

. 2006. Civilizing the Museum: The Collected Writings of Elaine Heumann Gurian. London and New York: Routledge.

—. 2006. "The Essential Museum". Te Ara: Journal of Museums Aotearoa no. 31 (1):412.

Isaac, Gwyneira. 2007. Mediating Knowledges: Origins of a Zuni Tribal Museum Tucson: The University of Arizona Press.

Haemata, Taiarahia Black, Daryn Bean, Waireka Collings, and Whitney Nuku. 2012. Conversations on Mātauranga Māori. Wellington: New Zealand Qualifications Authority.

Hakiwai, Arapata. 1988. "Museums as Guardians of our Nations Treasures". AGMANZ Journal no. 19.2 (2):35-38.

. 1994. "Ruatepupuke: Working Together, Understanding One Another". New Zealand Museums Journal no. 25 (1):44-52.

. 1997. Museums - On Whose Terms? Working "Inside Out". In International

Symposium on Representing Cultures in Museums. National Museum of Ethnology, Osaka and the Setagaya Art Museum, Tokyo.

. 2004. "Māori Taonga, Māori Identity". In International Bar Association-Session:

Art, Cultural Institutions \& Heritage Law 'Going, going, gone: buying and selling at auction'. Auckland.

—. 2005. "The Search for Legitimacy: Museums in Aotearoa, New Zealand - A Māori Viewpoint". In Heritage, Museums and Galleries: An Introductory Reader, edited by Gerard Corsane, 154- 162. London \& New York: Routledge. . 2006. "Māori Taonga - Māori Identity". In Art \& Cultural Heritage: Law, Policy and Practice, edited by Barbara T. Hoffman, 409-412. New York: Cambridge University Press.

- 2008. "The Protection of Taonga and Māori Identity in Aotearoa, New Zealand". In Decolonizing Conservation: Caring for Māori Meeting houses Outside New Zealand, edited by Dean Sully, 45-58. Walnut Creek, US: Left Coast Press.

Hakiwai, Arapata, and Philipp Schorch. 2014. "Mana Taonga and the public sphere: A dialogue between Indigenous practice and western theory". International Journal of Cultural Studies no. 17 (2):191-205.

Hakiwai, Arapata, and Huhana Smith. 2008. Toi Ora: Māori Ancestral Treasures. Wellington: Te Papa Press.

Hakiwai, Arapata, and John Terrell. 1994. Ruatepupuke: A Māori Meeting House in the Field Museum of Natural History: Chicago, Illinois. Chicago, Illinois: Field Museum.

Hall, Stuart. 1993. "Cultural Identity and Diaspora". In Colonial Discourse and Postcolonial Theory, edited by P. Williams and L. Chrisman, 392-403. Hertfordshire: Prentice Hall/Harvester Wheatsheaf. - 1996. “Who needs 'identity'?”. In Questions of cultural identity, edited by S. Hall and P. du Guy, 1-18. London: Sage.

1997. Representation: Cultural Representations and Signifying Practices. London:

Sage in association with The Open University.

Hamer, Paul. 2007. Māori in Australia: Ngā Māori i Te Ao Moemoeā. edited by Te Puni Kokiri. Wellington: Te Puni Kokiri.

Hawke's Bay Art Gallery and Museum Newsletter, 1985 
Hawke's Bay Art Gallery and Museum Annual Report, 1987

Hawke's Bay Cultural Trust Winter Programme Newsletter, 1989

Hawke's Bay Cultural Trust, 2005. Gottfried Lindauer: Te Renitawa. The Shadow Maker exhibition catalogue?

Healy, C, and A Witcomb. 2006. South Pacific Museums: Experiments in Culture. Melbourne: Monash University ePress.

Hedley, R. 2004. "Prototype Theory and the Concept of Taonga: Implications for Treatyrelated Issues such as the Display and Conservation of Taonga Maori." He Puna Korero: Journal of Maori and Pacific Development no. 5 (1):49-68.

Helin, Calvin. 2006. Dances with Dependency: Out of Poverty through Self-Reliance. California: Ravencrest Publishing.

Henare, Amiria. 2005. Museums, Anthropology and Imperial Exchange. Cambridge: Cambridge University Press . 2007a. "Taonga Māori: Encompassing Rights and Property in New Zealand". In Thinking through Things: Theorising Artefacts in Ethnographically, edited by Amiria Henare, Martin Holbraad and Sari Wastell, 47-67. London and New York: Routledge. . 2007b. "Thinking through things :theorising artefacts in ethnographic perspective." In Clothing as Material Culture, edited by Amiria Henare, Martin Holbraad and Sari Wastell, 121-138. Milton Park, Abingdon, Oxon ;New York Routledge. 2007c. "Ngā Rākau a Te Pākehā: Reconsidering Māori Anthropology." In Anthropologies and Science: Epistemologies in Practice, edited by Jeanette Edwards, Penny Harvery and Peter Wade, 93-113. Oxford, New York: Berg.

Henare, Manuka. 2003. The Changing Images of Nineteenth Century Mãori Society - From tribes to nation. $\mathrm{PhD}$, Māori Studies, Victoria University of Wellington. Wellington.

Hill, Richard W. 2000. “The Museum Indian: Still Frozen in Time and Mind”. Museum News no. 79 (3):40-44.

. 2001. "Regenerating Identity: Repatriation and the Indian Frame of Mind". In The Future of the Past: Archaeologists, Native Americans and Repatriation, edited by T.L. Bray, 127-138. New York: Garland Publishers.

_. 2007. "Regenerating Identity: Repatriation and the Indian Frame of Mind". In Museums and their communities, edited by Sheila Watson. London \& New York: Routledge.

Hill, Richard S. 2004. State Authority, Indigenous Autonomy: Crown Relations in New Zealand/Aotearoa 1900-1950. Wellington: Victoria University Press.

Hill, R. Sr. 1994. "Repatriation:an opportunity for cultural exchange". American Indian Object Repatriation Foundation News \& Notes no. 1(1) (Spring).

Hill, T., and T. Nicks. 1992. "The Task Force on Museums and First Peoples". Muse no. 10 (2-3):81-84.

Holland, J, and C Ramazanoglu. 1994. "Coming to Conclusions: Power and Interpretation in Researching Young Women's Sexuality”. In Researching Women's Lives from a Feminest Perspective. Edited by M. Maynard and J. Purvis, 125-48. London: Taylor $\&$ Francis.

Holloway L., and P Hubbard. People and Place: The Extraordinary Geographies of Everyday Life Essex. England: Prentice Hall, 2001.Hooper-Greenhill, Eilean. 1992. Museums and the Shaping of Knowledge. London \& New York: Routledge. 1998. "Perspectives on Hinemihi - a Māori meeting house." In Colonialism and the Object, edited by Tim Barringer and Tom Flynn, 129-143. London and New York: Routledge. 1999. Museums and Interpretive Communities. In Musing on Learning. Australian Museum, Sydney. 
2006. "The Power of Museum Pedagogy". In Museum Philosophy for the Twentyfirst Century, edited by Hugh Genoways, 235-245. Altamira Press.

. 2007. Museums and Education: Purpose, Pedagagy, Performance. London and New York: Routledge.

Jahnke, Huia. 2002. "Towards a secure Māori identity: Māori women and the home-place". Women's Studies International Forum no. 25 (5):503-513.

Johnstone, Liesl. 2009. "Marks of an ancestor". Te Karaka (44).

Jones, Shane. 1994a. Museums, Tourism and Māori. In Destination Museum: Issues of Heritage, Museums and Tourism. Wellington City Gallery. . 1994b. "Museums and the Treaty of Waitangi". In A Framework for Funding and Performance Measurement of Museums in New Zealand. Museum Directors Federation, Taonga o Aotearoa National Services of the Museums of New Zealand. . 2006. "Development and Māori society: building from the centre or the edge?". In Culture and Sustainable Development in the Pacific. Edited by Antony Hooper, 159173. Canberra, Australia: Asia Pacific Press.

Ka'ai, Tania M, John C Moorfield, Michael P J Reilly, and Sharon Mosley. 2004. Ki te Whaiao: An Introduction to Māori Culture and Society. Auckland: Pearson Lomgman.

Karp, Ivan, and Steven D. Lavine. 1991. Exhibiting Cultures: The Poetics and Politics of Museum Display. Washington: Smithsonian Institution Press.

Kawharu, Merata. 2002. "Indigenous Governance in Museums: A Case Study, The Auckland War Memorial Museum". In The Dead and their Possessions: Repatriation in Principle, Policy and Practice, edited by Fforde, Cressida, Jane Hubert and Paul Turnbull. London: Routledge.

Kernot, Bernie. 1987. “Te Māori Te Hokinga Mai: Some Reflections”. AGMANZ no. 18 (2):3-7.

Kersey, Harry A. 2000. Indigenous Sovereignty in two cultures: Māori and American Indians compared. Wellington: Treaty of Waitangi Research Unit Report.

Kirshenblatt-Gimblett, Barbara. 1998. Destination Culture: Tourism, Museums and Heritage. Berkeley University of California Press.

Knell, Simon J. 2007. Museums in a Material World. London \& New York: Routledge.

Knell, Simon J., Suzanne Macleod, and Sheila Watson. 2007. Museum Revolutions: How Museums Change and are Changed. London and New York: Routledge.

Ko Aotearoa Tenei; Te Taumata Tuatahi, Wai 262. 2011. Wellington: Legislation Direct. Ko Aotearoa Tenei; Te Taumata Tuarua, Wai 262. 2011. Wellington: Legislation Direct. Kreps, C. 1994. "The Paradox of Cultural Preservation in Museums". The Journal of Arts Management, Law and Society no. 23 (4):291-304.

Kreps, Christina. 2003. Liberating Culture: Cross-Cultural Perspectives on Museums, Curation and Heritage Preservation. London \& New York: Routledge.

- 2007. "The Theoretical Future of Indigenous Museums: Concept and Practice". In The Future of Indigenous Museums: Perspectives from the Southwest Pacific, edited by Nick Stanley, 223-234. New York \& Oxford: Berghahn Books.

Lohman, Jack. 2007. "Repatriation in the Service of Society and its Development". In Repatriation in the Service of Society and its Development, edited by Mille Gabriel and Jens Dahl. Copenhagen, Denmark: Eks-skolens Trykkeri.

Lonetree, Amy. 2006. "Introduction: Critical Engagements with the Smithsonian's National Museum of the American Indian." American Indian Quarterly no. 30 (3 \& 4):5-7-510. . 2009. "Museums as Sites of Decolonization: Truth Telling in National and Tribal Museums." In Contesting Knowledge: Museums and Indigenous Perspectives, edited by Susan Sleeper, 322-337. Lincoln: University of Nebraska Press. 
2012. Decolonizing Museums. Representing Native America in National and Tribal Museums. Chapel Hill: The University of North Carolina Press.

Maaka, Roger 1994. "The New Tribe: Conflicts and Continuities in the Social Organization of Urban Maori." The Contemporary Pacific no. 6 (2):311-336.

. 2003. Perceptions, conceptions and realities: a case study of the tribe in Maori society in the twentieth century. $\mathrm{PhD}$, Political Science, Canterbury, Christchurch.

Maaka, Roger, and Augie Fleras. 2005. The Politics of Indigeneity: Challenging the State in Canada and Aotearoa New Zealand. Otago: University of Otago Press.

Macdonald, Sharon, and Gordon Fyfe. 1996. Theorizing Museums: Representing identity and diversity in a changing world. Oxford, UK and Cambridge, USA: Blackwell Publishers.

Macdonald, S., and G. Fyfe. 1998. The Politics of Display: Museums, Science, Culture. London \& New York: Routledge.

Mahuika, Apirana. 2010. “A Ngāti Porou Perspective". In Weeping Waters: The Treaty of Waitangi and Constitutional Change, edited by Malcolm Mulholland and Veronica Tawhai, 145-163. Wellington: Huia Publishers.

Makoare, Bernard. 1999. "Kaitiakitanga i roto i nga Whare Pukapuka: Appropriate Care for Maori Materials in Libraries and Archives." Archifacts Bulletin of the Archives and Records Association of New Zealand 18-26.

Manaia, W., and D. Hona. 2005. The Changing Face of Māori Development: Mauri Kaiarahi: Māori Leadership Values. http://www.firstfound.org/manai and hona.htm

Mane-Wheoki, Jonathan. 1993. Mataatua: No wai tenei whare tupuna? A Report on the Ngāti Awa Claim (Wai 46). Commissioned by the Waitangi Tribunal. Waitangi Tribunal. . 2003. "A New Flowering of Ngāi Tahu Art/Toi o Ngāi Tahu: He Puāwaitanga Hou". In Te Puāwai o Ngāi Tahu: Twelve Contemporary Ngāi Tahu Artists, edited by Anna Rogers, 18-33. Cristchurch: Spectrum Print Ltd.

- 2005. "He Kahui Whetu Hou Contemporary Māori Artists: A New Constellation". In Art and Social Change: Contemporary Art in Asia and the Pacific, edited by Caroline Turner, 498-513. The Australian National University: Pandanus Books.

McCarthy, Conal. 2004. From Curio to Taonga: A genealogy of display at New Zealand's National Museum, 1865-2001. PhD, Museum \& Heritage Studies, Victoria University of Wellington, Wellington.

2005. "Objects of Empire? Displaying Māori at International Exhibitions, 18731924". Journal of New Zealand Literature: Special Issue no. 23 (1):52-70.

. 2007. Exhibiting Māori: A History of Colonial Cultures of Display. Oxford and New York: Berg and Te Papa Press.

2009. "Post-colonial Pasts and Post-indigenous Futures: A Critical Genealogy of

'Māori art"' In Crossing Cultures: Conflict, Migration and Convergence. The

Proceedings of the 32nd International Congress in the History of Art, edited by Jaynie Anderson, 803-808. Melbourne: The Miegunyah Press.

2011. Museums and Māori: Heritage Professional, Indigenous Collections, Currrent Practice. Wellington: Te Papa Press.

McIntosh, Tracey. 2005. "Māori identities: Fixed, fluid, forced”. In New Zealand identities: departures and destinations, edited by J. Liu, T. McCreanor, T. McIntosh and T. Teaiwa, 38-51. Wellington: Victoria University Press.

McLoughlin, M. 1999. Museums and the Representation of Native Canadians and First Nations. Vancouver: University of British Columbia Press.

Mead, H M. 1984. Te Māori: Māori art from New Zealand Collections. New York and Auckland: Heinemann. American Federation of Arts.

Mead, Sidney (Hirini) Moko. 1983. "Indigenous Models of Museums in Oceania". Museum 
no. 35 (139):98-101.

. 1985a. "Te Māori: A Journey of Rediscovery for the Māori people of New Zealand". TRIPTYCH Magazine of the Asian Art Museum, M.H.de Young Memorial Museum no. June-July:11-18.

. 1985b. "Celebrating New Zealand's Cultural Heritage: A Māori Point of View". In Interpreting Cultural Diversity, edited by J Hoyle, 16-21. Museum Education Association of New Zealand.

. 1986a. "Art Objects as Taonga: Spiritual Values and Power in Māori Art". Field Museum of Natural History Bulletin no. 57 (2):6-10; 19-23.

1986b. Magnificent Te Māori: Te Mãori Whakahirahira. Auckland: Heinemann. 1990. "The Nature of Taonga". Paper read at Taonga Māori Conference, New Zealand, $18^{\text {th }}-27^{\text {th }}$ November 1990,1991 , at Wellington.

. 1990. "Tribal Art as Symbols of Identity". In Art and Identity in Oceania, edited by

Alan Hanson and Louise Hanson, 269-281. Honolulu: University of Hawai'i.

1990. "Ngā Karoretanga O Mataatua Whare: The Wanderings of the Carved House

Mataatua." In Research Report no.2. Whakatane: Te Rūnanga o Ngāti Awa, p. 10

1992. "The nature of taonga". In Taonga Māori Conference Proceedings, New

Zealand, 17-27 November 1990, edited by Mark Lindsay, 164-9. Wellington:

Department of Internal Affairs.

. 1993. "The Maintenance of Heritage in a Fourth World Context: The Māori Case."

In Artistic Heritage in a Changing Pacific, edited by Dark Phillip and Rose Roger, 223-231. Honolulu: University of Hawai'i Press.

. 1994. Iwi Culture Centres and Tribal Museums. Unpublished Report, Te Maori

Manaaki Taonga Trust.

1995. "The Mataatua Declaration and the Case of the Carved Meeting House

Mataatua." In Material Culture in Flux: Law and Policy of Repatriation of Cultural

Property, edited by J. et al. Wong et al. Vancouver: University of British Columbia

Faculty of Law

1997. Mãori Art on the World Scene: Essays on Mãori Art. Wellington: Ahua

Design \& Illustration Ltd.

. 2003. Tikanga Māori: Living by Māori Values. Wellington: Huia Publishers.

2011. "Ko Aotearoa tēnei: A report into claims concerning New Zealand law and

policy affecting Māäori culture and identity". Wellington, Waitangi Tribunal. Te

Taumata Tuarua: Volume 2:.510.

Mead, Hirini Moko. 2012. "Understanding Mātauranga Māori and Global Indigenous

Knowledge." In Conversations On Mātauranga Māori, edited by Haemata Ltd, T.

Black, D Bean, W. Collins and W. Nuku, 9-14. Wellington: New Zealand

Qualifications Authority.

Melbourne, Hineani. 1995. Maori Sovereignty: The Maori Perspective. Auckland: Hodder

Moa Beckett.

Merryman, John Henry, and Albert Edward Elsen. 2002. Law, Ethics, and the Visual Arts.

4th ed. Aspen: New York.

Message, Kylie 2006. New Museums and the Making of Culture. Oxford \& New York: Berg.

Milroy, Wharehuia. 2008. "Indicators of Tribal Identity in Aotearoa/New Zealand". Te

Kaharoa no. 1:183-192.

Mitchell, J.H. 1944 and 1972. Takitimu: A History of the Ngāti Kahungunu People: Reed

Publishing.

Murphy, Hinehaea. 1999. Bicultural Developments in Museums of Aotearoa - A Way

Forward: Te Kaupapa Tikanga-a-rua ki roto i nga Whare Taonga o Aotearoa-Anei

ko te Huarahi. Wellington: Museum of New Zealand Te Papa Tongarewa. 
Neich, Roger. 1994. Painted Histories: Early Māori Figurative Painting. Auckland: Auckland University Press.

. 2001. Carved Histories: Rotorua Ngāti Tarawhai Woodcarving. Auckland:

Auckland University Press.

Ngā Mōteatea Part One, song 66 pp.294-297. 2004. Auckland: Auckland University Press.

Ngata, Wayne, Hera Ngata-Gibson, and Amiria Salmond. 2012. "Te Ataakura: Digital taonga and cultural innovation". Journal of Material Culture no. 17 (3):229-244.

Ngā Taonga o Tamatea Catalogue, 1990

Nicks, Trudy. 2003. "Museums and Contact work: Introduction." In Museums and Source Communities, edited by Laura Peers and Alison Brown, 19-27.

O'Biso, Carol. 1987. First Light. New York: Paragon House.

O'Regan, Gerard. 1997. "Biculturalism, The Treaty of Waitangi and the Spirit of Partnership". New Zealand Museums Journal no. 26 (2):28-30.

. 2008. "The Shifting Place of Ngāi Tahu Rock Art". In Islands of Inquiry:

Colonisation, edited by G. Clark, F. Leach and S. O'Connor, 411-422. Canberra:

ANU E Press.

O’Regan, Hana. 2001. Ko Tahu, Ko Au: Kai Tahu Tribal Identity. Christchurch: Horomaka Publishing.

—. 2006. "State of the Reo Nation: Māori Language Learning". In State of the Māori

Nation: Twenty-first Century issues in Aotearoa, edited by Malcolm Mulholland, 157168. Auckland: Reed.

2009. "Toitu te iwi - A journey in the evolution of cultural identity". Te Kaharoa no. 2:77-88.

O'Regan, Tipene. 1987. "Who Owns the Past? Change in Māori Perceptions of the Past." In From the Beginning: The Archaeology of the Mäori, edited by J. Wilson, 141-145. Auckland: Penguin Books in association with the New Zealand Historic Places Trust. 1994. "The Ngāi Tahu Claim". In Waitangi: Māori and Pakeha Perspectives of the Treaty of Waitangi, edited by I. H. Kawharu, 234-262. Auckland: Oxford University Press.

. 1994. "Māori Control of the Māori Heritage". In The Politics of the Past, edited by P.Gathercole and D.Lowenthal. London: Unwin Hyman..

- 2008. "Mo tatou, mo ka uri a muri ake nei". In Mãori Business Symposium: Intergenerational Wealth - Re-igniting Indigenous Economies - Muramura Ahi Kaa ki Uta, Muramura Ahi kaa ki Tai. Otago.

O'Sullivan, Dominic. 2007. Beyond Biculturalism: The Politics of an Indigenous Minority. Wellington: Huia Publishers.

Packer, Laura, Paul Rankin, and Robin Hansteen-Izora. 2007. "Empowering Narratives for Minority Cultures". AEN Journal no. 2 (1).

Parsons, Patrick. 1990. "Treasures of old CHB revealed." Hawkes Bay Herald Tribune nd.

Paulin, Charlotte. 2005. "Focus on the Ngāi Tahu Tribe". International Journal of Entrepreneurship and Small Business no. 2 (2):199-207.

Pauling, Craig, and Kepa Brian Morgan. 2006. Te Kaupapa o Te Whare: House of Tahu Cultural Sustainability Assessment. Ngāi Tahu Property Ltd.

Pearce, Susan. 1992. "Making Museum Meanings." In Museums, Objects and Collections: A Cultural Study, 118-143. Leicester, London: Leicester University Press.

Pearce, Susan. 1994. "Objects as meaning: or narrating the past." In Interpreting objects and collections, edited by Susan Pearce, 19-29. London \& New York: Routledge.

Peers, Laura, and Alison K Brown. 2003. Museums and Source Communities: A Routledge Reader. London: Routledge. 2007. "Museums and Source Communities". In Museums and their communities, 
edited by Sheila Watson, 519-537. London \& New York: Routledge.

Phillips, Ruth B. 2011. Museum Pieces: Toward the Indigenization of Canadian Museums.

Montreal \& Kingston; London; Thaca: McGill-Queen's University Press.

Phillips, W.J., and J.C. Wadmore. 1956. The Great Carved House Mataatua of Whakatane.

Wellington: Valley Printing Company, Petone.

Pittams, Grant. 1999. Te Arotake i Te Kaupapa Tiaki i te Mauri o te Matauranga - Wairarapa:

An Evaluation of the Cultural Property Pilot Project - Wairarapa. Wellington:

National Library of New Zealand.

Pittams, Grant. 2002. Partnership in Action: Kahungunu - Ka Moe ... ka Puta ... : An

Evaluation of the Exhibition. edited by Grant Pittams. Wellington: National Library of New Zealand.

Poata-Smith, E.S. Te Ahu. 2004. "The Changing Contours of Māori Identity and the Treaty Settlement Process". In The Waitangi Tribunal: Te Ropu Whakamana i te Tiriti o Waitangi, edited by Janine Hayward and Nicola Wheen, R. Wellington: Bridget William Books.

Poole, Ross. 1999. Nation and Identity. London \& New York: Routledge.

Procter, James. 2004. Stuart Hall by James Procter: Routledge.

Rangihau, John. 1992. "Being Māori”. In Te Ao Hurihuri - Aspects of Māoritanga, edited by Michael King, 185-190. Auckland: Reed Books.

Raymond, Rosanna, and Amiria Salmond. 2008. Pasifika Styles: Artists Inside the Museum: University of Cambridge Museum of Archaeology and Anthropology, Cambridge, in association with Otago University Press.

Rosoff, Nancy. 2003. "Integrating Native Views into Museum Procedures: Hope and Practice at the National Museum of the American Indian". In Museums and Source Communities: A Routledge Reader 72-80. New York: Routledge.

Royal, Charles. 2004. Mātauranga Māori and Museum Practice: A Discussion. Report prepared by Te Ahukaramu Charles Royal for National Services Te Paerangi. Wellington: National Services Te Paerangi, Museum of New Zealand.

Salmond, Anne. 1983. "The Study of Traditional Māori Society: the State of the art". The Journal of the Polynesian Society no. 92 (3):309-332.

Sandell, Richard. 2002. Museums, Society, Inequality. London \& New York: Routledge. . 2006. Museums, Prejudice and the Reframing of Difference. London and New York: Routledge.

Sharples, Pita. 2009. Manu Ao Academy Seminar - 'Maori Development'. Wellington: New Zealand Government.

Simpson, Mīria, and Patrick Parsons. 2003. Ngā Taumata: A Portrait of Ngāti Kahungunu He Whakaahua o Ngāti Kahungunu 1870-1906. Wellington: Huia, Ngāti Kahungunu Iwi Incorporated, National Library of New Zealand.

Simpson, Moira G. 1996. Making Representations: Museums in the Post-Colonial Era. London \& New York: Routledge.

. 2007. "Charting the boundaries: Indigenous models and parallel practices in the development of the post-museums". In Museum Revolutions: How Museums Change and Are Changed, edited by S.J. Knell, S. MacLeod and Sheila Watson, 235-249. London New York: Routledge.

. 2009. "Museums and restorative justice: heritage, repatriation and cultural education". Museum International no. 61 (1-2):121-129.

Sissons, Jeffrey. 2005. First Peoples Indigenous Cultures and their Futures. London: Reaktion.

Skinner, Damian. 2008. The Carver and the Artist: Māori Art in the Twentieth Century. Auckland Auckland University Press. 
Skrudstrup, Martin. 2007. "RIGHTING WRONGS? Three Rationales of Repatriation and what Anthropology might have to say about them". In UTIMUT: Past Heritage Future Partnerships, edited by Mille Gabriel and Jens Dahl, 56-63. Copenhagen, Denmark: IWGIA.

Smith, Jo, and Katharina Ruckstuhl. 2010. "The case of Te Karaka: Ngāi Tahu print media before and after settlement". Alter Native no. 6 (1):25-37.

Smith, Linda Tuhiwai. 1999. Decolonizing Methodologies: Research and Indigenous Peoples. Dunedin/London/New York: University of Otago Press/Zed Books Ltd.

—. 2000. "Kaupapa Māori research”. In Reclaiming Indigenous voice and vision, edited by M Battiste, 225-247. Canada: UBC Press.

Solomon, Mark. 2006. "Ngāi Tahu Post-Settlement". In State of the Māori Nation, edited by Malcolm Mulholland, 209-217. Auckland: Reed. 2009. Mō Ka Uri - Our Vision for the Ngāi Tahu Settlement.

Spedding, Mike. 2006. “Te Aitanga a Hauiti and the Tairawhiti Museum”. Te Ara: Journal of Museums Aotearoa no. 31 (1):27-31.

Stanley, Nick. 2007. The Future of Indigenous Museums: Perspectives from the Southwest Pacific. New York \& Oxford: Berghahn Books.

Starzecka, Dorota. 1998. Mãori Art and Culture. 2nd ed. London: The British Museum Press. Statistics New Zealand, 2006, Census data.

Statistics New Zealand. 2012. Te Ao Marama, 2012: A Snapshot of Māori well-being, Wellington: Statistics New Zealand.

Sullivan, John. 2002. "The Portraits of Samuel Carnell: The Representation of Ngāti Kahungunu in Colonial Photography". History of Photography no. 26:351-357.

Sullivan, Tim, Linda Kelly, and Phil Gordon. 2003. "Museums and Indigenous People in Australia: A Review of 'Previous Possessions, New Obligations: Policies for Museums in Australia and Aboriginal and Torres Strait Islanders". Curator no. 42 (2):208-227.

Sully, Dean. 2007. Decolonising Conservation: Caring for Māori Meeting Houses outside New Zealand. Walnut Creek, California: Left Coast Press Inc.

Tahana, Yvonne. 2012. "Greedy 'sharks' circling Ngāti Porou”. New Zealand Herald.

Tapsell, Paul. 1996. "Taonga and Obligations of Reciprocity". New Zealand Museums Journal no. 26 (1):26-29. 1997. "The Flight of Pareraututu: An Investigation of Taonga from a Tribal Perspective". The Journal of the Polynesian Society no. 4 (106):323-374. . 2000. Pukaki: A Comet Returns. Auckland: Reed. . 2002. "Partnership in Museums: A Tribal Māori Response to Repatriation." In The Dead and their Possessions: Repatriation in Principle, Policy and Practice edited by Cressida Fforde, Jane Hubert and Paul Turnbull, 285-292. London: Routledge. . 2003. "Beyond the Frame: An Afterword". In Museums and Source Communities: A Routledge Reader, edited by Laura Peers and Alison K Brown, 242-251. London \& New York: Routledge. 2004. " From the sideline: Tikanga, Treaty Values and Te Papa." In Waitangi Revisited: Perspectives on the Treaty of Waitangi, edited by M Belgrave, M Kawharu and D Williams, 266-282. Melbourne: Oxford University Press. 2006. Ko Tawa: Māori Treasures of New Zealand. Auckland: David Bateman Ltd. . 2011a. “'Aroha mai: Whose museum?': The rise of indigenous ethics within museum contexts: A Māori-tribal perspective". In The Routledge Companion to museum ethics: Redefining Ethics for the Twenty-First-Century Museum, edited by Janet Marstine, 85-111. London \& New York: Routledge.

- 2011b. The Art of Taonga. Wellington: Art History, Victoria University of 
Wellington.

Tau, Te Maire. 1992. Kurakura Ngāi Tahu. MA, Canterbury, Christchurch.

- 2003. Nga Pikituroa o Ngāi Tahu: The Oral Traditions of Ngāi Tahu. Otago:

University of Otago Press.

Tau, Te Maire, and Atholl Anderson. 2008. Ngāi Tahu: A Migration History The Carrington Text. Wellington: Bridget Williams Publishing.

"Te Aitanga-a-Hauiti The Descendants of Hauiti." 2007. Te Ao Maori i Te Tairawhiti, 7th December 2007.

Te Awekotuku, Ngahuia. 1996. Who called this a club? Issues of power, naming and provenance in Mäori collections held overseas. Paper read at Keynote paper Museums Australia Conference Power and empowerment- preparing for a new millennium, at Australia.

Te Awekotuku, Ngahuia, and Linda Nikora. 2003. Nga Taonga o Te Urewera: A Report prepared for the Waitangi Tribunal's Urewera District Inquiry, August, 2003 (Wai 894, doc B6).

Te Awekotuku, Ngahuia, and Linda Nikora. 2007. Mau Moko: The World of Māori Tattoo. North Shore: Penguin Viking.

Te Karere Māori News.1st February 2010 'Te Aitanga-a-Hauiti uses 3D technology to access their traditional taonga.'

Te Rito, J. 2007. "Whakapapa: A Framework for Understanding Identity”. MAI Review no. 3:1-8.

Te Rūnanga o Ngāti Porou Annual Report 2010.

Te Rūnanga o Ngāti Porou Annual Report 2011.

Thomas, Nicholas. 1991. Entangled Objects: Exchange, Material Culture, and Colonialism in the Pacific. Cambridge: Harvard University Press.

1995. Oceanic Art. London: Thames and Hudson.

1999. Possession: Indigenous Art/Colonial Culture. London: Thames \& Hudson Ltd.

Thomas, Nicholas, and Mark Adams. 2009. Rauru: Tene Waitere, Māori carving, Colonial History. Dunedin: Otago University Press.

Thompson, Keith W. 1981. Art Galleries and Museums in New Zealand. Wellington: Reed. Toi Hauiti at Māori Art Market 2011 promotional pānui.

Torrie, Bronwyn. 2011. "Te Papa to lose treasured Māori whare". The Dominion Post, $8^{\text {th }}$ October 2011, 2.

Torsen, Molly, and Jane Anderson. 2010. Intellectual Property and the Safegurading of Traditional Cultures: Legals Issues and Practical options for Museums, Libraries and Archives. World Intellectual Property Organization.

Trope, J., and W. Echo-Hawke. 2000. "The Native American Graves Protection and Repatriation Act: Background and Legislative History". In Repatriation Reader: Who Owns American Indian Remains?, edited by D Mihesuah, 123-168. Lincoln: University of Nebraska Press.

Tūria, Tāriana. 2000. "Self-governance”. He Pukenga Korero no. 5 (2):48-50. 2002. Matariki, and Māori Cultural Heritage. New Zealand Government. 2007. Tariana Turia's opening speech for Te Pihi Mata Whanganui Regional Museum.

UNESCO. 2002. "UNESCO Universal Declaration on Cultural Diversity: a vision, a conceptual platform, a pool of ideas for implementation, a new paradigm". In Cultural Diversity Series No.1, edited by UNESCO. Paris, France.

Waitangi Tribunal. 2004.'Turanga Tangata, Turanga Whenua: The Report on the Tūranganui-a-Kiwa Claims' (Wai 814) for Te Hau ki Tūranga (Chapter 10). 
2011. "Ko Aotearoa Tēnei: A Report into Claims Concerning New Zealand Law and Policy Affecting Māori Culture and Identity".

Walker, Ranginui. 2001. Tipua: The Life and Times of Sir Apirana Ngata. Auckland: Penguin Books.

Wanhalla, Angela C. 2010. "The Politics of 'Periodical Counting': Race, Place and Identity in Southern New Zealand". In Making Space: Settler-colonial perspectives on land, place and identity, edited by Penelope Edmonds and Tracey Banivanua, 198-217. London: Palgrave Macmillan.

Warren-Findley, Jannelle. 2014. "Book Review: Lonetree, Decolonizing Museums: Representing Native America in National and Tribal Museums". Pacific Historical Review no. 83 (1):156-157.

Wassman, Jurg. 1998. Pacific Answers to Western Hegemony: Cultural Practices of Identity Construction. Oxford: New York: Berg.

Watson, Sheila. 2007. Museums and Their Communities. London \& New York Routledge.

Watt, L. 2005. "American Indian Tribes and their Museums". Te Ara: Journal of Museums Aotearoa no. 30 (1):10-13.

Weil, Stephen E. 2002. Making Museums Matter. Washington D.C.: Smithsonian Institution Press.

West, Rick. 1993. "The New Inclusiveness". Anthropology News no. 34 (2): 39-40. . 2004. "As Long as we keep dancing". In Spirit of a Native Place: Building the National Museum of the American Indian, edited by Duane Blue Spruce, 47-65. Washington: National Geographic Society. .2004. The Changing Presentation Of The American Indian. Washington: University of Washington Press.

. 2004. "The National Museum of the American Indian: Steward of the Sacred". In Stewards of the Sacred, edited by Lawrence E Sullivan and Alison Edwards, 7-17. American Association of Museums in co-operation with the Center for the Study of World Religions, Harvard University.

—. 2005. "Cultural Futures". In The Native Universe and Museums in the Twenty-First Century, edited by Mark Hirsch and Amy Pickworth. Washington D.C., and New York: National Museum of the American Indian, Smithsonian Institution.

Wetere, Koro. 1986. "Comments on the Te Māori Exhibition". AGMANZ Journal no. 77 (3):6.

Whaanga, Mere. 2003. "Telling our stories: Hapu identity in waiata, pakiwaitara and visual arts". In Mãori and Oral History: a Collection, edited by Rachael Selby and Allison Laurie, 23-27. Palmerston North: Massey University.

- 2004. A Carved Cloak for Tahu. Auckland: Auckland University Press.

White, Paul. 2000. "Restoration of the tribal collective: Rebuilding tribal capacity alongside economic development". He Pukenga Korero no. 5 (2):41-44.

Winkin, Yves. 2002. "Cultural Diversity: A Pool of Ideas for Implementation". In UNESCO Universal Declaration on Cultural Diversity, edited by Katerina Stenou, 17-60. Paris, France: United Nations Educational, Scientific and Cultural Organization.

Wisker, Gina. 2008. The Postgraduate Research Handbook. New York: Palgrave Macmillan. Reprint, 2nd.

Woods, Tom. 1989. The Report of the Department of Māori Affairs on the Claim of Ngāti Awa for the return of Mataatua House: Te Ripoata a te Tari Māori e pa ana ki te tono a Ngāti Awa mo tona whare mo Mataatua. Department of Māori Affairs 